\title{
Bound Together: Slavery and Democracy in Antebellum Northwestern Virginia, 1815--1865
}

\author{
Adam Zucconi
}

Follow this and additional works at: https://researchrepository.wvu.edu/etd

\section{Recommended Citation}

Zucconi, Adam, "Bound Together: Slavery and Democracy in Antebellum Northwestern Virginia, 1815--1865" (2016). Graduate Theses, Dissertations, and Problem Reports. 7058.

https://researchrepository.wvu.edu/etd/7058

This Dissertation is protected by copyright and/or related rights. It has been brought to you by the The Research Repository @ WVU with permission from the rights-holder(s). You are free to use this Dissertation in any way that is permitted by the copyright and related rights legislation that applies to your use. For other uses you must obtain permission from the rights-holder(s) directly, unless additional rights are indicated by a Creative Commons license in the record and/ or on the work itself. This Dissertation has been accepted for inclusion in WVU Graduate Theses, Dissertations, and Problem Reports collection by an authorized administrator of The Research Repository @ WVU.

For more information, please contact researchrepository@mail.wvu.edu. 
Bound Together: Slavery and Democracy in Antebellum Northwestern Virginia, 1815-1865

\author{
Adam Zucconi \\ Dissertation submitted \\ to the Eberly College of Arts and Sciences \\ at West Virginia University \\ in partial fulfillment of the requirements for the degree of \\ Doctor of Philosophy in \\ History
Jason Phillips, Ph.D., chair
Brian Luskey, Ph.D.
Kenneth Fones-Wolf, Ph.D.
Kimberly Welch, Ph.D.
Aaron Sheehan-Dean, Ph.D.
Department of History
Morgantown, West Virginia
2016

Keywords: Virginia; West Virginia; U.S. Civil War; Slavery; Democracy; Antebellum Era;

Politics; Political Parties

Copyright 2016 Adam Zucconi 


\begin{abstract}
Bound Together: Slavery and Democracy in Antebellum Northwestern Virginia, 1815-1865
\end{abstract}

\title{
Adam Zucconi
}

Since West Virginia's founding in 1863, historians have attempted to understand the forces that shaped the state's creation. Most historians have argued that the Mountain State's admission into the Union represented a grassroots rebellion among democratically-minded mountaineers who had long resisted the rule of eastern slaveholding aristocrats. The tumultuous events triggered by secession and civil war provided the opportunity for westerners to inaugurate their long desired wishes to free themselves from their allegedly tyrannical brethren and abolish the institution that many residents blamed for their woes: chattel slavery.

West Virginia's founding proved more contingent and complex than previously argued. During the early antebellum era, western Virginians displayed their loyalty to the state and to slavery through public processions, meetings, and editorials. Residents insisted, however, that their eastern brethren assist in reforming and democratizing the state's constitution. The Constitutional Convention of 1829-1830 failed to include all of western Virginians' desires but the changes included in the new constitution broadened the franchise and reflected powerful market forces fundamentally politics in the Old Dominion.

The 1830 Constitution helped foster, however, a new understanding of the symbiotic relationship between slavery and democracy. Importantly, western Virginians embraced this interpretation. During the 1840 s and 1850 s, as national events concerning slavery became more frequent, western Virginians continued to profess their support for the peculiar institution and to the state. Such assertions contributed to the ratification of a new constitution in 1851, as western Virginians' desire for a democratized constitution finally came to fruition. The new constitution deepened residents' attachment to chattel slavery and the state, a critical development as abolitionists appeared more menacing and Republicans cultivated a presence in the Northwest. Few northwesterners supported either party because the destruction of slavery threatened the foundation of their political rights, another important development wrought by the new constitution. Rather than drifting farther apart from their eastern brethren in sentiment and principle, northwesterners drew closer and became fierce proslavery advocates.

The national crisis that began to unfold in 1860 threatened to disrupt the harmony between western and eastern Virginians. Western Virginians maintained that remaining within the Union and under the protection of the constitution would ensure democratic rights while protecting slavery, too. Though eastern Virginians voted to take the Commonwealth out of the Union, westerners differed on the path ahead. Rather than forging ahead in demolishing slavery and the state, residents debated the merits of creating a new state and how to resolve the issue of slavery. After multiple and intense debates and recognizing that the war would not end quickly, northwesterners voted to create a new slave state. West Virginia entered the Union in 1863 but its founding reflected the state's history of slavery, not the democratic revolution posited by historians. Proponents of West Virginia's founding insisted that the state's establishment would perpetuate, not undermine, racial hierarchy. While West Virginia's founders ratified a proposal to gradually emancipate slaves, emancipation would unfold over decades and shifting political and racial norms threatened to sabotage that process in the future. West Virginia's future remained firmly wedded to Virginia's slaveholding past. 


\section{Acknowledgements}

This dissertation represents the culmination of numerous individuals who have contributed their time, effort, and wisdom to seeing this project through from start to finish. At Bridgewater College, David McQuilkin proved to be a tireless supporter while I was an undergraduate and continues to follow my development at each stage. My adviser, Stephen Longenecker, identified my interest in history while at Bridgewater College and encouraged me to pursue postgraduate work. He remains an important friend and mentor.

My tenure at Clemson University was important and transformative. Rod Andrew uncovered my interest in the antebellum South and the ideas that helped form that critical period. Paul Anderson, my adviser, set a high bar for teaching, mentoring, and being an historian. He took my often incoherent thoughts and helped channel them into stronger and more constructive arguments. Many of the interpretations expressed within this dissertation reflect the countless discussions concerning antebellum society, Virginia, and West(ern) Virginia he and I shared.

At WVU, I had the privilege of studying under Aaron Sheehan-Dean. Aaron was a consummate adviser: he eagerly shared teaching advice, engaged in thoughtful discussions about my research interests, and displayed patience throughout this whole process. Even after he left for Louisiana State University, he remained devoted to my project and to my overall development. This dissertation would not have been possible without him. Jason Phillips made the transition between advisers seamless, as he embraced the challenge of taking on an advisee two years into the process. He improved my dissertation's clarity and overall argument and provided important critiques for the next stage. Brian Luskey offered important insight into teaching, writing, and thinking like an historian while Ken Fones-Wolf always expressed a willingness to discuss the historical issues and quandaries I encountered while thinking about my dissertation. Kimberly Welch likewise offered excellent advice and avenues for broadening my dissertation's impact. Finally, though he and I may have competing alma maters, Tyler Boulware has remained a source of encouragement and friendship during my time at WVU.

During my academic career, I had the pleasure of training alongside historians who will continue to shape the discipline. Scott MacKenzie, Jacob Ivey, Brandon Williams, David Goldberg, Josh Esposito, Karina Esposito, and Joe Rizzo are all excellent historians in their own right. They also provided much-needed relief and friendship over the course of my career. I am thankful that these friendships have continued even after we have followed different tracks after graduation. And, while not an historian, Tim Shayne has remained a true and thoughtful friend.

This dissertation would not have been possible without the assistance from the Virginia Historical Society and the West Virginia and Regional History Center. A Mellon Fellowship in 2014 provided an important week of research at the VHS where the helpful staff tracked down sources and suggested some I had not considered. The staff at the WVRHC proved incredibly accommodating during my countless visits to their archives. Kevin Fredette, Jane LaBarbara, Catherine Rakowski, Anna Schein, Michael Thobois, and the entire staff at the WVRHC located sources, directed me to new sources, and continually encouraged me during my research.

The support and encouragement offered by my family made this dissertation and my entire postgraduate career possible. My in-laws, John and Darlene Wells, offered their continued support throughout my time at Clemson and West Virginia University. Likewise, Joey Zucconi, Michael Zucconi, and Stephanie Zucconi inspired me to continue my education and pursue a doctorate. My parents, John and Susan Zucconi, have been a constant source of inspiration and strength. They cultivated my passion for history and education in general and motivated me at 
each stage throughout my career. They also instructed me beyond academics and helped shape the person I am today and for that I am eternally grateful.

My wife, Brittany Zucconi, knows more than anyone the sacrifices, challenges, and triumphs that have accompanied this dissertation and my postgraduate career. Her unwavering support, encouragement, and love inspired me while her example as a passionate teacher amazed me. Our son, Connor, continues to bless us each and every day, and I remain incredibly thankful for the life we share. These few words of praise to Brittany and Connor will never fully reflect the depth of my gratitude and love but I will labor each day to manifest those feelings. 
Table of Contents

Introduction .1

Chapter 1: Defining Freedom: Freeholds, Republican Citizenship, and the Grassroots Movement for Democratic Reform .18

Chapter 2: Reformers' Victory: the 1829-1830 Constitutional Convention 55

Chapter 3: A Peculiar Détente: The Rise of Proslavery and Pro-Democratic Thought, 1830-1850 .98

Chapter 4: "Whitening” Politics: Slavery, Politics, and the 1851 Constitution. .144

Chapter 5: Defeating the "mongrel platform": Partisan Politics, Slavery, and the Limited Appeal of the Republican Party, 1856-1861 .196

Chapter 6: Preserving the Union and Slavery: Secession and the Statehood Movement, 18611862. 252

Chapter 7: (Some) Mountaineers are Always Free: Statehood and Preserving Racial Hierarchy, 1862-1863 300

Conclusion: The Long Shadow: The Politics of Slavery in West Virginia, 1863-1865..352

Bibliography 362 
Introduction: New Contours for an Old Debate: Slavery and Sectionalism in Antebellum Northwest Virginia

In 1866, West Virginia Senator Waitman T. Willey responded to proposals considered by the Virginia Legislature that sought reunification between the two states. Willey dismissed Virginia politicians who considered the Mountain State's creation merely "“a war measure,"” arguing instead that long-standing sectional grievances finally dismembered the Old Dominion. The "perpetual strife" between eastern and western Virginians, Willey claimed, had threatened to divide the state on numerous occasions. The Civil War provided the "opportunity" western Virginians needed to "carry into effect a long cherished desire." The "strife" cited by Willey reflected geographical, commercial, constitutional, and political grievances that had festered over the preceding decades. West Virginia and Virginia constituted two "geographically distinct" states, "physically separated" by mountains that prohibited social and commercial interaction. "[L]ittle or no traffic or commerce" existed between eastern and western antebellum Virginians while the "different...manners, customs, education, habits, and feelings" exhibited by these residents illustrated that two peoples had occupied one state. ${ }^{1}$

West Virginians' reluctance to embrace their erstwhile brethren manifested their belief that their new state constitution contained the democratic measures and principles for which they had long pursued. For decades, antebellum western Virginians had sought equal representation in the state legislature, universal male suffrage, uniform taxation, state-supported internal improvements, and a public education system, among other issues. Few of these reforms, however, had been inaugurated by 1861. The Mountain State's creation, though, provided West Virginians the opportunity to democratize their state government. The "system of free schools

\footnotetext{
${ }^{1}$ Waitman T. Willey, A Letter from Hon. W.T. Willey, on the Redintegration of Virginia (Washington, D.C.: n.p., 1866), 3, 5.
} 
and public education" along with the "improved organizations of county police, townships...[and] our constitutional protection against the creation of burdensome public debts" represented a few of the fundamental changes West Virginians had instituted in 1863. A "reunion of the States would doubtless result in the surrender of those fundamental reforms inaugurated under our new constitution," Willey explained. Reunification "would ruin us."2

West Virginia's creation, however, did not reflect western Virginians' antipathy toward slavery. Though the "long, loud, and persistent clamors" from eastern Virginians suggested that westerners opposed African American bondage and sought the institution's demise, Willey insisted that transmontane Virginians had supported slavery and slaveholders' rights. Willey could not uncover "a single fact which... warrant[ed] any just apprehension on the part of eastern alarmists" on the subject of slavery. West Virginians had never exhibited "bad faith" in defending the "lawful rights of the eastern slaveholder." Willey characterized accusations that questioned his neighbors' fealty toward slavery as "unfounded" and slanderous. West Virginians had defended and championed slavery for decades, even when their eastern neighbors doubted such fidelity. ${ }^{3}$

Historians have generally agreed with Willey's argument concerning the inevitability of the Old Dominion's dismemberment during the Civil War but dismissed his interpretation of northwesterners' proslavery credentials. The sectional strife that Willey emphasized, historians insist, represented tangible concerns that divided Virginians along geographic lines. Contemporary historians, including Theodore F. Lang and Granville Davisson Hall, maintained that political, constitutional, and economic inequalities augmented eastern Virginians' power while restricting that of western Virginians. Though other southerners had democratized state

\footnotetext{
${ }^{2}$ Willey, Redintegration of Virginia, 6, 8 .

${ }^{3}$ Willey, Redintegration of Virginia, 5.
} 
constitutions and inaugurated majoritarian rule, Virginia slaveholders resisted such measures for decades, worried that democracy and slavery could not coexist. Efforts to maintain unequal representation in the state legislature, tax breaks for slaveholders, and enfranchisement for only propertyholders represented slaveholders' futile attempts to stem the irresistible march of democratic reform in Virginia. Western, nonslaveholding yeomen demanded democratic reform regardless of the consequences on slavery. ${ }^{4}$

These political and constitutional differences convinced these earlier historians that two distinct civilizations occupied one polity. Hall insisted that the "unnatural" connection between them eventually devolved into a "union of force" that "only awaited its opportunity to be broken." Eastern Virginians" "aristocratic communities" reflected their stubborn belief that “slave labor" provided necessary "political and social wisdom.” Western Virginians disagreed with their Tidewater brethren. The "commoner people" who inhabited the western mountains rejected slavery and embraced free labor, an ideology Hall considered "the genius of the great free Republic.” Unlike eastern Virginians' static and hierarchical society, westerners' fostered an egalitarian, vibrant, and dynamic free labor society. ${ }^{6}$ Looking back, Hall pondered how Virginians failed to recognize the "irrepressible conflict" between their two sections. ${ }^{7}$

Modern historians have supported this interpretation that two separate societies shared one government, a prospect that forecasted conflict. Henry T. Shanks and Charles Ambler averred that inequality in internal improvements, political representation, and constitutional powers between the two sections heightened intrastate sectional antagonism and deepened

\footnotetext{
${ }^{4}$ Theodore F. Lang, Loyal West Virginia from 1861 to 1865: With an Introductory Chapter on the status of Virginia for Thirty Years prior to the War (Baltimore: Deutsch \& Co., 1895) and Granville Davisson Hall, The Rending of Virginia: A History (Chicago: Mayer and Miller, 1902).

${ }^{5}$ Hall, Rending of Virginia, 30.

${ }^{6}$ Ibid., 34.

${ }^{7}$ Ibid., 37.
} 
resentment between the two sections. Western Virginians shipped their manufactured goods and natural resources to western markets, including Pittsburgh, Louisville, and Cincinnati, an economic characteristic that illustrated Virginia's geographical diversity and the lack of internal improvements created by the state legislature needed to overcome such obstacles. The statehood movement, Shanks concluded, represented "part of a long sectional rivalry" rooted in "sectionalism and economic differentiation." 8

Charles Ambler, a protégé of Frederick Jackson Turner, argued that western Virginians embodied the democratic and individualistic ideals of frontier experience. Eastern Virginians languished, meanwhile, in an older and aristocratic society; only their control and manipulation of constitutional functions and structures allowed them to fend off westerners' democratic advances. Northwesterners' support for the Republican Party during the late 1850s and 1860s signaled their attempt to break easterners' political hegemony and inaugurate majoritarian power. Their tactic worked. Though Ambler concluded his seminal study before 1863, his interpretation provided a clear explanation for dismemberment and West Virginia statehood. Western Virginians, tired of living under aristocratic rule, formed a democratic state cleansed from the previous political and constitutional ills that had infected the Old Dominion. ${ }^{9}$

More recent historians, however, have emphasized the political diversity of western Virginia. Richard Orr Curry, John Alexander Williams, and Ken Noe have dismissed the monolithic antislavery and unionist interpretation of the transmontane region offered by previous historians. Curry, utilizing a broader primary source base than his predecessors, stressed the

\footnotetext{
${ }^{8}$ Henry T. Shanks, The Secession Movement in Virginia, 1847-1861 (Richmond: Garnett and Massie, 1934), 3, 211 212. For a similar interpretation concerning sectionalism, see George Ellis Moore, "Slavery as a Factor in the Formation of West Virginia," West Virginia History, 18, no. 1 (October 1956): 5-89.

${ }^{9}$ Charles H. Ambler, Sectionalism in Virginia from 1776 to 1861 (Chicago: University of Chicago Press, 1910), 3$10,116-118,318,337$.
} 
Northwest's heterogeneous population and diverse political environment. These differences became manifest during the secession crisis and statehood movement, as secessionist meetings and anti-statehood gatherings occurred in most northwestern counties. ${ }^{10}$ The presence of southern sympathizers, John Alexander Williams argues, illustrated that a "buckskin elite" controlled local politics akin to their more refined eastern neighbors. Using the county court system to consolidate power and land holdings, this "buckskin elite" exercised their brand of political hegemony during campaigns and elections. The democratic west offered by Ambler represented a façade, according to Williams. ${ }^{11}$ Ken Noe's research on the Virginia and Tennessee Railroad in southwest Virginia confirms Williams' argument concerning a more politically diverse west. The railroad, constructed and maintained by slave labor, facilitated the rise and expansion of key industries that utilized slave labor, including tobacco, lead mining, iron production, salt and plaster, and coal mining. All of these products found buyers in eastern markets including—and arguably most importantly—Richmond. By the late 1850s, southwest Virginians readily identified their interests with those of Piedmont and Tidewater Virginians, not their northwestern neighbors. ${ }^{12}$

\footnotetext{
${ }^{10}$ Richard Orr Curry, A House Divided: A Study of Statehood Politics and the Copperhead Movement in West Virginia (Pittsburgh: University of Pittsburgh Press, 1964).

${ }^{11}$ John Alexander Williams, "The New Dominion and the Old: Ante-bellum and Statehood Politics as the Background of West Virginia's 'Bourbon Democracy,”'West Virginia History, 33, no. 4 (July 1972): 317-407. Williams draws a sharp contrast with these "buckskin elite" from the more prominent statehood leaders who hailed from the Northwest. Individuals like Waitman T. Willey, John Carlile, and Francis H. Pierpont operated in a different political and economic climate. They concentrated on mobilizing a literate electorate increasingly engaged in industrial and commercial farming operations. Here, appeals to deference and isolation fell on deaf ears, while the ideals of nationalism and democracy gained traction. Yet, Williams notes, their time as the leaders of West Virginia remained brief because of the inclusion of Democrats and former Confederates into the body politic in 1872. During this constitutional convention, "buckskin elites" controlled the proceedings and reintroduced the country court system along with the viva voce method of voting, too. Each of these reforms reestablished local political control and facilitated the rebirth of the old ruling elite. After the dust settled in 1872, West Virginia operated remarkably like it had before the Civil War. While traditionalists lauded the emerging egalitarian ethos within western Virginia before the war, Williams remained skeptical about a democratic west and the power local rulers wielded.

${ }^{12}$ Kenneth W. Noe, Southwest Virginia's Railroad: Modernization and the Sectional Crisis (Urbana: University of Illinois Press, 1994), 60-61, 63-82.
} 
Recognizing western Virginia's involvement in championing slavery and slaveholding interests continues to be overlooked by historians, however. Indeed, more recent historians, in interpreting Virginia's antebellum sectionalism and dismemberment during the Civil War, have stressed the fatal struggle between democratic government and chattel slavery that unfolded in the Old Dominion during this era. William Shade, William Freehling, William Link, Sean Wilentz, and Stephanie McCurry maintain that efforts to reconcile or promote equilibrium between these two institutions were myopic and doomed. While economic expansion promoted democratic reform in Virginia, William Shade suggests that demographic trends signaled an approaching crisis concerning slavery. Western Virginia's growing nonslaveholding population, increasingly involved in professions outside of plantation agriculture, would invariably demand majoritarian power, a prospect eastern slaveholders and elites viewed grimly. ${ }^{13}$ This demographic trend, William Freehling notes, created "white-belts" in Virginia, notably in the Northwest, where residents possessed little personal, financial, or political investment in slavery. ${ }^{14}$ White southerners, rather than displaying unity on the issue of slavery and democratic reform, exhibited divisions that would widen with time. ${ }^{15}$

This alleged inevitable struggle between democratic government and chattel slavery in Virginia and in the nation has received broad scholarly support. William Link argues that economic expansion and industrialization alienated northwestern Virginians from the state's

\footnotetext{
${ }^{13}$ William G. Shade, Democratizing the Old Dominion: Virginia and the Second Party System, 1824-1861 (Charlottesville: University Press of Virginia, 1996).

${ }^{14}$ William W. Freehling, The South vs. the South: How Anti-Confederate Southerners Shaped the Course of the Civil War (New York: Oxford University Press, 2001).

${ }^{15}$ William W. Freehling, The Road to Disunion: Secessionists at Bay, 1776-1854 (New York: Oxford University Press, 1990) and The Road to Disunion: Secessionists Triumphant, 1854-1861 (New York: Oxford University Press, 2007). Alison Goodyear Freehling similarly argues that white Virginians remained a divided slaveholding community throughout the 1820 s and 1830 s, as the failure to inaugurate democratic reform in the 1830 Constitution or pass some form of comprehensive emancipation following the Nat Turner rebellion placed the state (and the nation) on a "drift toward dissolution." Alison Goodyear Freehling, Drift Toward Dissolution: the Virginia Slavery Debate of 1831-1832 (Baton Rouge: Louisiana State University Press, 1982).
} 
slaveholding culture. Northwesterners' alienation encouraged residents to support the Republican Party in an effort to limit slavery's expansion in Virginia and the nation and protect the "moral and economic health of herrenvolk democracy." 16 Virginia's rending reflected the endgame in a half-century conflict that pitted slaveholding interests against majoritarian rule and democratic principles, a conflict Link considers inexorable. Sean Wilentz and Stephanie McCurry offer similar interpretations stressing the fatal struggle between the institutions of democracy and slavery. Debates concerning democratic reform in Virginia "widened" the "breach" between the "western...country democrats and the eastern slaveholder gentry." West Virginia's creation offered the only resolution to this issue. ${ }^{17}$ Stephanie McCurry supports Wilentz's argument, insisting that "modern" political thought and chattel slavery represented two antagonistic systems incapable of coexistence. Only white southerners blinded by their "hubris" and an "impoverished political vision" could not forecast conflict concerning black bondage and white liberty, McCurry argues. Slavery's destruction in 1865, therefore, represented an appropriate coda to white southerners' attempts to balance the two institutions. ${ }^{18}$

West Virginia's creation appears to support many of the arguments offered by historians. Virginia's intense sectionalism prior to the Civil War strengthens interpretations suggesting that two distinct peoples developed on either side of the Allegheny Mountains, with each section possessing different political, economic, social, and cultural interests. Foremost among such differences was that concerning slavery. With few slaves and fewer slaveholders, western Virginia appeared as a declining "society with slaves" that showed glimpses of the "free labor"

\footnotetext{
${ }^{16}$ William A. Link, “'This Bastard New Virginia': Slavery, West Virginia Exceptionalism, and the Secession Crisis," West Virginia History: A Journal of Regional Studies, 3, no. 1 (2009): 40.

${ }^{17}$ Sean Wilentz, The Rise of American Democracy: Jefferson to Lincoln (New York: W.W. Norton \& Company, 2005), 341-347.

${ }^{18}$ Stephanie McCurry, Confederate Reckoning: Power and Politics in the Civil War South (Cambridge: Harvard University Press, 2012), 83.
} 
future that awaited northern states. Western Virginia's proximity to Ohio and Pennsylvania and commercial relations with western and northern markets strengthened the bonds between residents and their northern neighbors while attenuating such ties with eastern Virginians. The region's small and declining slave population encouraged residents to embrace political and constitutional principles established on natural rights, not property rights, a mindset that contrasted sharply with Tidewater and Piedmont slaveholders. Western Virginians, unable to inaugurate meaningful constitutional and political reform and thoroughly democratize the state constitution because of easterners' paranoia and fear, embraced the Republican Party to manifest their democratic desires. This "free labor" and "free soil" party would guide transmontane Virginians through secession and civil war, ultimately helping to construct a democratic state freed from slavery’s corrupting influences.

This gospel of sectionalism and antislaveryism concerning West(ern) Virginia, however, overlooks important developments that shaped residents' reactions to dismemberment, statehood, democracy, and slavery. The sectionalism that Willey noted and other historians have echoed since 1863 existed but not necessarily to the degree posited. Eastern Virginians' refusal to support internal improvements or endorse constitutional reform frustrated westerners who often expressed their outrage at the ballot box, notably in the widespread rejection of the 1830 Constitution. And while a few outspoken individuals advocated a division of the state in 1830 and again in 1850 to permanently sever the two regions and end sectional strife, most northwesterners dismissed this ludicrous suggestion. Two-party politics bound northwesterners with other Virginians across the state, as the Democratic and Whig parties transcended geographical boundaries and fostered the growth of "imagined" political communities. ${ }^{19}$

\footnotetext{
${ }^{19}$ Benedict Anderson, Imagine Communities: Reflections on the Origin and Spread of Nationalism (New York: Verso Press, 1991).
} 
Further, northwesterners held in deep regard their Virginia heritage and expressed reluctance to discard their birthright. Northwesterners and their eastern neighbors shared similar foes, too, notably northern abolitionists and Republicans, men who appeared to threaten established and traditional hierarchies. Issues such as free public schools, greater political representation for non-propertyholders, and more state-funded internal improvements west of the Alleghenies often divided Virginians along sectional lines but such grievances never reached a level of severity that threatened state harmony. Northwestern Virginians affirmed and reaffirmed their fealty toward the state on countless occasions throughout the antebellum era, even during the secession crisis and beginning stages of the Civil War. During the statehood movement, leaders and residents bickered over the propriety and significance of leaving Virginia, eventually stumbling their way to West Virginia's creation. While a few northwestern Virginians maintained the steady drumbeat of sectionalism in the antebellum era, most residents preferred the rhythm of a unified Virginia.

While Willey and other historians have exaggerated the intense sectionalism that characterized antebellum Virginia, Willey's argument concerning northwesterners' deep investment in protecting slavery and slaveholders' interests highlighted a fundamental (and accurate) component of Northwest politics. During the antebellum era, northwesterners stressed their fealty toward to the peculiar institution, attempting to calm eastern Virginians' fears that they posed an acute threat to their human property. At each constitutional convention and in 1861, northwesterners pledged their support for slavery and slaveholders' rights, promising not to disturb the master-slave relationship while vowing to disarm any perceived threat. Northwesterners' defense of slavery reflected residents' belief that black bondage ensured and generated white liberty. Indeed, rather than perceiving the two institutions as antagonistic, 
northwesterners viewed them as symbiotic. Existing in a state of equilibrium, chattel slavery and democratic government provided the greatest political freedom available to white southerners. Regardless of the volatile economic climate or what party ruled the governor's mansion or White House, white northwesterners' political freedom remained sacrosanct and protected. But democracy and slavery, two fragile institutions, required white northwesterners' continued vigilance lest some force, group, or ism threaten them. A handful of white northwesterners opposed this political dynamic, frustrated about slavery's centrality to politics while other interests appeared to languish. But the majority of residents embraced this dynamic, cognizant that their political representation depended upon African Americans' exclusion.

The statehood movement exemplified northwesterners' stance on slavery and dismemberment. Following Virginia's adoption and ratification of the Ordinance of Secession in early 1861 , few northwesterners predicted or advocated a division of the state or slavery's destruction. An abrupt end to the political and military conflict unfolding around the nation threatened to embarrass northwesterners who endorsed radical action, including dividing the state or removing slavery from the region. Indeed, at each key political moment, northwestern politicians and residents introduced strong arguments for not dividing the state and not destroying slavery. Only when their democratic rights appeared vulnerable did residents support separation but the issue of African American bondage loomed large. Slavery proponents worried about political and racial miscegenation, fearful that the hierarchies that shaped northwesterners' lives would be dismantled with slavery's abolition. Accordingly, many such proponents rejected statehood lest racial equality be foisted upon them by northwestern Republicans and their alleged abolitionist allies. Statehood supporters, however, assured residents that African Americans 
would remain politically marginalized and socially subordinate in the new state. In short, statehood promised to protect western Virginians' racial democracy.

The decades preceding West Virginia's creation demonstrates that previous scholarship tracing the state's genesis to alleged bitter sectionalism and burgeoning antislaveryism misinterprets northwestern residents' attachment and devotion to Virginia and chattel slavery. White northwesterners' demands for greater political representation represented their belief that enfranchising non-propertyholders and basing representation solely on the white population would protect slaveholders' investment in human property. With all white men exercising identical political and constitutional rights, possibly divisive differences that could threaten slaveholders' prerogatives and the master-slave relationship would be removed from the body politic. Democracy and slavery, locked in a symbiotic relationship, would guarantee harmony and stability within Virginia regardless of sectional differences. ${ }^{20}$ Though democratization arrived later in Virginia than in other southern slaveholding states, the measures inaugurated in 1851 strengthened northwesterners' attachment to the state and its institutions and deepened their

\footnotetext{
20 "Democracy" is a potent, contested, and slippery word to define. In the strictest political sense, "democracy" means "rule of the people," where citizens have a direct voice in, among other privileges, ratifying or rejecting legislation and directly electing candidates. Majoritarian rule represents a fundamental characteristic of this form of government. While nineteenth-century Americans accepted this definition, limiting "democracy" to solely describing a form of government narrows analysis and overlooks "democracy's" cultural power, too. "Democracy" not only meant broad, if not universal, enfranchisement for white men, direct election of public officials, justice meted out irrespective of status, representation based not on property but people, and constitutional equality but a society that reflected this broad political equality. This equality meant, according to Sean Wilentz, "changing human relations between governors and the governed," a seminal transformation that shaped American political, social, intellectual, cultural, and economic systems. Indeed, political "democracy" often precipitated or closely followed changes in "human relations" in other arenas, creating an environment conducive to challenging established norms in every aspect of American society. As Wilentz notes and this dissertation emphasizes, however, "democracy" represents a fragile system that can be manipulated, limited, or dismantled, requiring vigilance from citizens regardless of wealth, political affiliation, or any other cleavage. Accordingly, this dissertation employs "democracy" in its broadest sense, one that encompasses not only the political characteristics embedded in the word but its transformative characteristics outside of the political sphere. Wilentz, Rise of American Democracy, XVIIIXIX.
} 
engagement in the "politics of slavery." Northwesterners became fiercely loyal to Virginia and to chattel slavery.

This loyalty to the state and its central institution shaped northwesterners' reactions to the political crises of the 1850s. Residents elected proslavery politicians, censured those who wavered, and endorsed slavery's centrality in politics. Northwesterners drew closer in Virginia's political orbit, not further away, even with the Republican Party's arrival. By 1861, the disagreement between northwesterners and their eastern brethren centered not on slavery's propriety or its presence in the Old Dominion but rather how best to protect the institution. Though a majority of residents insisted that remaining under the power of the federal government and U.S. Constitution would achieve that end, others endorsed the Confederate States of America to protect slavery from encroaching Republicans and their abolitionist allies.

This debate shaped residents' interpretation of statehood, too. Statehood proponents maintained that separating from Virginia would protect white residents' political rights while preserving their racial superiority even with the adoption of gradual emancipation. Statehood opponents disagreed, arguing that without chattel slavery, racial distinctions would collapse and political and social anarchy would reign. Though statehood divided these two groups, preserving racial hierarchy united them. West Virginia's creation, therefore, represented neither a clean break from residents' Virginian or southern ethos nor a democratic, antislavery revolution. The Mountain State's founding represented a triumph of racial democracy, a state created to preserve and perpetuate political privileges for white residents. The liberi expressed in West Virginia's motto applied only to white residents, not African Americans.

This study employs a chronological narrative to track northwesterners' deepening support for democratic government and chattel slavery. Chapter One provides background to the intense 
debate in early antebellum Virginia concerning democratization. Tidewater and Piedmont politicians and slaveholders expressed reticence on this issue, worrying that unmooring political and constitutional rights from property threatened stability. Property meant both landed and human, two forms that few western Virginians owned. Transmontane Virginians maintained that natural rights, not property rights, should be the basis for government. Residents also took great pains to display their fealty toward slavery and slaveholders' rights, a chief concern for many eastern Virginians. This debate reached a crescendo in 1829, as delegates across the state convened in Richmond to modify the state constitution.

Chapter Two explores the 1829-1830 Constitutional Convention, a moment many historians suggest hastened Virginia's “dissolution." The convention, however, provided the foundation necessary for later democratization. Though northwestern delegates failed to inaugurate all the democratic principles they wished, their victory in enlarging the franchise validated the changing economic and political context rapidly unfolding around them. Still, residents expressed outrage that eastern elites had prevented democracy's inevitable march on Virginia soil, an outrage expressed at the ballot box and in talk of dismemberment. Such talk, however, quickly faded as residents enjoyed the broader franchise and events in southeastern Virginia directed residents' attention to chattel slavery.

Nat Turner's Rebellion, coming on the heels of the constitutional convention, posed an important challenge to slaveholders across the state and politicians who championed the proslavery cause. Chapter Three analyzes how Virginia proslavery and prodemocracy ideologues reconceptualized African American bondage to broaden its appeal and stress its centrality to republican government. The three principal figures in this movement, Benjamin Watkins Leigh, Charles Dew, and Abel P. Upshur, helped establish the contours of a new 
proslavery ideology that appealed to nonslaveholders in Virginia and across the south. Their tactic worked. By 1850, northwesterners deepened their engagement in the "politics of slavery" and strengthened their commitment to slavery and slaveholders' interests. The final piece in solidifying residents' support for the institution and the state rested on democratizing the state constitution.

Chapter Four examines the Constitutional Convention of 1850-1851 and its dramatic effects on Virginia's political culture. During the convention, northwestern delegates stressed their constituents' fealty toward chattel slavery, the overriding issue at the convention. Eastern planters and politicians doubted such faithfulness. With northerners becoming more vocal in their opposition to slavery and abolitionists possibly operating within the state, slaveholders needed property qualifications to protect their investment, easterners insisted. But, with assistance from Henry A. Wise, northwesterners adopted a democratic constitution that inaugurated universal male suffrage and equalized representation while strengthening the state government's commitment to slavery. The impact of the new constitution became manifest immediately, as gubernatorial campaigns centered on the issue of slavery. While the "politics of slavery" had characterized northwestern politics prior to 1851 , the adoption of the new constitution deepened residents' engagement and heightened the dangers of not protecting Virginia's new racial democracy.

Not all northwestern Virginians, however, embraced slavery’s increased centrality to politics. Chapter 5 focuses on the emergence of the Republican Party, a political organization that attracted some northwesterners with its message of "free soil" and "free labor." Those that supported the party believed that the Republican Party could alter the political calculus of the state by offering residents an alternative to the two-party system that strengthened slaveholders' 
power over the state. Despite previous scholarship arguing otherwise, Republicans remained alien to most residents. Republicans' policies closely mirrored those of northern abolitionists to most northwesterners, drawing condemnation and violence from voters. Rather, up through the 1860 presidential election, most northwesterners remained committed to the two-party system and supportive of traditional Democratic and Whiggish nominees. As the secession crisis began to unfold following the election, most residents remained steadfast that the Union, not the nascent Confederacy, provided the best means for protecting white residents' democratic rights and chattel slavery.

Chapter Six examines northwesterners' arguments concerning secession in early 1861 and the beginning stages of the statehood movement. During the Richmond convention convened in February 1861, most northwestern delegates expressed their constituents' firm attachment to the Union, citing their desire to protect their democratic rights and the institution of slavery. A handful of northwestern delegates opposed the Union, insisting that secession would protect those two critical institutions. President Lincoln's call for troops following Fort Sumter's bombardment convinced a majority of delegates statewide, including a few from the Northwest, that the Republican administration sought slavery's destruction; accordingly, most delegates statewide ratified the secession ordinance. Northwesterners opposed to secession convened meetings and conventions across the region to discuss dividing the state, a proposition that appeared fraught with obstacles and far from certain. But as the idea of statehood gained currency in the Northwest, few politicians or residents appeared willing to disturb the masterslave relationship. While some national Republicans considered slavery's destruction in the region a prerequisite for statehood, many residents expressed reluctance to abandon the institution. 
Chapter Seven analyzes how northwestern residents achieved statehood while still maintaining the region's system of racial hierarchy. Statehood proponents encouraged residents to support West Virginia's creation, insisting that the Mountain State's founding would accelerate a demographic "whitening" of the region already in progress. Freed and enslaved African Americans would be removed from the state while West Virginia's climate would deter other blacks from entering the new state. The few African Americans who remained would reside under draconian antebellum laws concerning freed blacks, as fines and corporal punishment remained on the books. These few blacks would labor in menial service positions, leaving more prosperous and prestigious positions for white residents. While statehood opponents maintained that West Virginia's creation would "blacken" the mountains, most residents argued that the state's founding would protect white equality and racial hierarchy. Admitted to the Union in 1863, West Virginia represented a triumph of racial democracy.

What unfolded in antebellum West(ern) Virginia and during the Civil War reflected broader developments convulsing the nation. Issues of race, citizenship, and democratic development shaped political debates in Virginia, New York, Tennessee, North Carolina, and California prior to the Civil War while a marked increase in European immigration post-1848 further raised the relationship between political fitness and skin color. The Civil War failed to settle these debates, as immediate post-war and Reconstruction developments reflected a continuation of these volatile issues.

The interplay between slaveholders and nonslaveholders in Virginia likewise reflected developments across the South that sought to tether the interests of the latter with those of the former. In states across the Deep South, state constitutions democratized political representation and power between the two classes and helped establish a precedent for other southern states. 
This slaveholders' democracy promised equal power and voice to all white men regardless of status or political affiliation. Slaveholders often couched their defense of slavery in terms of patriarchal defense and familial obligation, hoping these arguments would resonate with nonslaveholders. Numerous slaveholders also generated strong economic ties with their nonslaveholding neighbors that directly tied the financial well-being of one family with that of the other. When the war came, these bonds forged over the previous decades between the two groups often proved durable and strong as the mobilization of nonslaveholders into the Confederate army demonstrated. In Virginia, a similar dynamic unfolded except in western Virginia, where the defense of slavery acquired different meanings and produced different results. While this dissertation focuses on Virginia, in many instances what occurred in the Old Dominion reflected broader regional and national developments shaping the country as a whole in powerful ways. 
Chapter 1: Defining Freedom: Freeholds, Republican Citizenship, and the Grassroots Movement for Democratic Reform

In June 1824, “A HouSE KEEPER of Harrison County” wrote an open letter in the Clarksburg Intelligencer chiding his representative in Congress, Joseph Johnson. Two actions by Johnson drew the constituent's ire. First, Johnson refused to support William H. Crawford's candidacy in the upcoming presidential election, turning his back on a candidate who the author believed to have "deserve[d] the station." Johnson's other offense was his pro-tariff stance. While "all the other representatives from Virginia" had rightly denounced the measure and accordingly voted against it, Johnson embraced the tariff. "A HOUSE KEEPER" warned that such actions - especially when the people of western Virginia had unanimously rejected such deedswere dangerous for Johnson's political career. For now, western Virginians would watch their representative in earnest to observe any signs of repentance. ${ }^{1}$

A constituent writing a public letter scathing the conduct of a representative should not be surprising, especially to modern observers of the political process. Such actions were and are common, and are generally indicative of an engaged citizenry and a transparent democratic process, both hallmarks of western liberal democracies that have emerged and been refined since the Enlightenment. What should be surprising, given the context of the letter, is the author's self-proclaimed identity. The author lived under the 1776 Virginia Constitution, a republican document that ultimately regarded a "house keeper" as a dependent, disenfranchised resident who existed on the political margins. White men who owned the requisite amount of land decreed by the constitution, meanwhile, enjoyed the privileges, prerogatives, and burdens of the political sphere. But the self-identified “A HOUSE KEEPER of Harrison County” considered such distinctions artificial and arbitrary. In publicly chastising his representative, "A HoUSE KEEPER"

\footnotetext{
${ }^{1}$ Clarksburg Intelligencer, June 19, 1824, 2-3. [emphasis in original]
} 
understood that he stepped beyond his proscribed sphere and admitted that Johnson likely found his "stile... a little too dictatorial" considering his "signature." And the author also confessed that he "cannot vote at the elections and thereby express my utmost displeasure at your sins of omission and commission." Yet he pressed on, looking toward that silver lining in the distance. His "prospect[s] of...possessing that right at the next election, or the succeeding one at farthest, is increasing daily," he declared, and soon he would enjoy the sundry benefits and responsibilities inherent in republican citizenship. In the interim, he would continue to "arraign [politicians] at the bar of the public," broadcasting his approbation or disapproval through popular media. $^{2}$

The letter from "A HOUSE KEEPER” elucidates the central tension in antebellum Virginia's political system. While the traditional narrative of American democracy chronicles a constant, if not inexorable, increase in the political rights granted to free white men following the American Revolution, the vesting of such rights proved uneven. ${ }^{3}$ Indeed, while the national and geopolitical consequences of the American Revolution often proved widespread and dramatic, the domestic and political effects of the Revolution in Virginia proved limited. Elite Virginians worked diligently to harness the Pandora's Box that the American Revolution opened, ultimately ratifying a new constitution and passing laws designed to perpetuate their hegemony and curtail any liberal sentiments. Rather than inaugurating dramatic political and constitutional changes, Virginia elites embraced the status quo, with all the prevailing orthodoxies and ideologies inherent in this political system.

\footnotetext{
${ }^{2}$ Clarksburg Intelligencer, June 19, 1824, 2-3.

${ }^{3}$ Alexander Keyssar, The Right to Vote: The Contested History of Democracy in the United States (New York: Basic Books, 2000).
} 
But the letter from “A House KEEPER” reveals more than elite Virginians' refusal to embrace democratic reforms. While previous southern and Virginia historians have focused on tracing political and constitutional developments at the state and local levels, Virginia's political transformation cannot be grasped solely, or even mainly, from such a top-down perspective. ${ }^{4}$ The resulting interpretations have proven limited, overlooking the often subtle and latent cultural practices and values that antebellum Virginians associated with the political process. Notably, this top-down perspective marginalizes an increasing variety of actors engaging in public political activities and demanding full and equal political rights, including "A HOUSE KEEPER." A grassroots perspective allows a clearer picture of the increasingly broad realm of politics and political culture that came to form a central component of Virginians' lives, specifically those in the Northwest. And as men (and women) convened in barbeques, meeting houses, courts, and other public areas to discuss politics, what unfolded were often intense and rich debates about the meaning of politics and how to reconcile politics and power with changing social, economic, cultural, and demographic realities. In the Northwest, such debates and negotiations took on added urgency and importance, as many people demanded entry to a political process they deemed a natural right. To effect change in the political system, these residents engaged in popular politics to demonstrate the necessary virtues needed in a republic. In so doing, they also sought to direct other Virginians and southerners toward a reformed model of republican citizenship, one built not upon land ownership but upon the productive capacity of labor, the memory of the American Revolution, and the natural right to self-government. ${ }^{5}$

\footnotetext{
${ }^{4}$ See, for example, Ambler, Sectionalism in Virginia, and Fletcher M. Green, Constitutional Development in the South Atlantic States, 1776-1860: A Study in the Evolution of Democracy (New York: W.W. Norton, 1966).

${ }^{5}$ Christopher Michael Curtis uses the phrase "productive capacity of labor" to describe how slaveowners could stake a claim to political representation on the basis of their control of their chattel's labor. Alternatively, Northwestern residents pointed to their ability to control their labor and the benefit such labor provided the Commonwealth as grounds for their political representation. Christopher Michael Curtis, Jefferson's Freeholders and the Politics of Ownership in the Old Dominion (New York: Cambridge University Press, 2012).
} 
When elite eastern Virginians looked west toward the Blue Ridge and Allegheny Mountains, they viewed this vast western region with a mixture of fear, sublimity, and optimism. During the colonial era, elite eastern Virginians looked with trepidation toward the periphery of their world, mindful of the region's natural beauty and resources but wary of Native Americans and competing imperial powers. In an effort to bolster the defense of the colony and, later, the state, Virginians promoted settlements to act as a buffer between the more populous Tidewater and its western front. ${ }^{6}$ But the chaotic and disorganized manner in which settlers populated (or simply squatted) on the land produced political, cultural, and legal misunderstandings between these settlers and eastern elites. Settlers generally ignored title and ownership rights, flouting the traditional means of land ownership. The diverse ethnic composition of the settlers complicated matters further. Rather than the pure English stock that Tidewater Virginians claimed, Germans, Ulster-Scots, Swiss immigrants, and former indentured servants settled along the western front. The belief that Tidewater culture could be replanted and replicated west of the mountains appeared chimerical and fleeting. Up through the mid-nineteenth century, elite eastern Virginians continued to look skeptically toward their western brethren, seeming to recognize that such people, including “A HOUSE KEEPER,” could never fit the narrow definition of what constituted "true Virginia."7

Elites' deployment of “true Virginia” as a rhetorical instrument provides an important window into their governing ideology. From Virginia's colonial beginnings, these elite men embraced a hierarchical and patriarchal society based on republican ideology and derived from the planter-centered political economy of Tidewater Virginia. Contemporaries prized the virtues

\footnotetext{
${ }^{6}$ B. Scott Crawford, “A Frontier of Fear: Terrorism and Social Tension along Virginia's Western Waters, 1742 1775,” West Virginia History: A Journal of Regional Studies, 2, no. 2 (Fall 2008): 1-29.

${ }^{7}$ Leslie Scott Philyaw, Virginia's Western Visions: Political and Cultural Expansion on an Early American Frontier (Knoxville: University of Tennessee Press, 2004), IX-XXV, 24-39, 64-75, 123.
} 
and individual liberty that emanated from land ownership, notably economic self-sufficiency (achieved through slave labor) and physical independence. Both of those qualities, according to the tenets of republican ideology, attached these independent men to their community's interests and needs and represented the criteria essential to republican government. ${ }^{8}$ Accordingly, these men governed the colony's public affairs. Further, these leading men, labeled the "grandees of government" by one historian, expected deference and obedience from all those under their authority, including other white men, women, children, slaves, indentured servants, Native Americans, and other dependents. The hierarchical and patriarchal world created by the "grandees of government" and reinforced by republican ideology embodied the vision of "true Virginia," a vision that greatly shaped the state's political institutions and operations and political culture. ${ }^{9}$

The "grandees of government" enjoyed a fixed and respected place in the body politic. These men "imposed, preserved, and profited" from the political world they created, augmenting their power and that of their ilk. ${ }^{10}$ The House of Burgesses, county courts, and colonial governor all remained under the direction of these men, with all three branches of government functioning to further their power. Land ownership emerged as a prerequisite for suffrage in 1670, thereby excluding the less prosperous and landless. Supporters for the measure argued that landownership provided the strongest evidence of a man's investment in the colony's welfare and health. Accordingly, these men's voices should and did carry more weight. With their control of government nearly absolute, the grandees regulated everything from indentured servants' and enslaved laborers' behavior to religious beliefs to tobacco prices under the guise of

\footnotetext{
${ }^{8}$ Curtis, Jefferson's Freeholders, 54.

${ }^{9}$ Brent Tarter, The Grandees of Government: The Origins and Persistence of Undemocratic Politics in Virginia (Charlottesville: University of Virginia Press, 2013).

${ }^{10}$ Tarter, Grandees of Government, 8.
} 
patriarchal control and protection and republican virtue. The solidarity and harmony expressed by the grandees further shielded them from external assaults, solidifying their political power and their control over colonial governance. ${ }^{11}$

While the grandees' faces and names changed over the course of the seventeenth and eighteenth centuries, their worldview and ideology remained relatively static. The grandees' descendants continued to disproportionately control county and local offices, even as Virginia's population grew outside of the Tidewater. The handful of judges comprising the General Court crafted legislation, directed the course of the governor's administration, and used their influence over the governor to appoint family members to lucrative governmental posts. This small group of judges also navigated land grants through complex bureaucracy, gaining valuable information on land. And as the number of qualified voters, candidates, defeated incumbents, and contested election results declined, the grandees continued to exert greater hegemony over the political system they created. ${ }^{12}$

But the American Revolution altered the power dynamic, threatening that carefully crafted hegemony. In the years leading up to and surrounding the Revolution, a powerful “evangelical counterculture” jeopardized elites’ loci of power, including courthouses, by challenging the cultural authority wielded by leading men. ${ }^{13}$ Residents increasingly petitioned the state legislature on elective matters, notably on the issue of voter qualifications. Women, free blacks, and, less often, slaves, authored other petitions touching on private and communal matters. ${ }^{14}$ In November 1775 , the high turnover of elected officials in county elections reflected

\footnotetext{
${ }^{11}$ Tarter, Grandees of Government, 59-71.

${ }^{12}$ John Gilman Kolp, Gentlemen and Freeholders: Electoral Politics in Colonial Virginia (Baltimore: Johns Hopkins University Press, 1998), 36-80.

${ }^{13}$ Rhys Isaac, The Transformation of Virginia, 1740-1790 (Chapel Hill: University of North Carolina Press, 1992).

${ }^{14}$ Richard Beeman, The Varieties of Political Experience in Eighteenth-Century America (Philadelphia: University of Pennsylvania Press, 2004), 56-57.
} 
an increasingly restive constituency and tenant farmers protested the high rents that landholders charged. ${ }^{15}$ Such actions revealed the democratizing potential of the war and perhaps presaged a slow move toward more popular politics. While many of the actors who argued for redress and change lacked political representation, their actions suggested that the fervor and rhetoric surrounding the American Revolution permitted such measures. These actions suggested an alarming trend for Virginia's elites who could not help but fret about their loosening grip over the colony's dependents and public affairs. ${ }^{16}$

The means for re-securing elites' political power rested on two legislative achievements. In June 1779, the General Assembly passed two statutes both aimed at strengthening the rights and power of freeholders, men who owned a tenure of land for life. One statute abolished all forms of feudal tenure while the other statute proclaimed that all lands in Virginia would now be under the sole jurisdiction of the landholder. Both laws strengthened the hands of freeholders by allowing them to develop, transfer, or sell their land at will, a move directed toward reconciling the increasing commodification of land with the republican political virtues inherent in land ownership. Equally important, the laws represented the state legislators' reaffirmation that the freehold would constitute the new state's constitutional foundation. Propertied men would continue to preside over and protect the republic, prizing their interests and voices and those of their ilk over those of dependents across the Commonwealth. ${ }^{17}$

Along with tackling the politics of landownership, the legislature also ratified a new constitution. Rejecting the revolutionary ideals of egalitarianism and inclusivity, the framers

\footnotetext{
${ }^{15}$ Michael McDonnell, The Politics of War: Race, Class, and Conflict in Revolutionary Virginia (Chapel Hill: University of North Carolina Press, 2007), 127-128, 190-191.

${ }^{16}$ Landon Carter perhaps best exhibited this type of fear. Carter watched as his political world and personal world on his plantation transformed around him, testing his ties to the British Crown, fellow Virginians, his family, and his slaves. Rhys Isaac, Landon Carter's Uneasy Kingdom: Revolution and Rebellion on a Virginia Plantation (Oxford: Oxford University Press, 2004).

${ }^{17}$ Curtis, Jefferson's Freeholders, 53-54.
} 
crafted the state constitution to perpetuate and strengthen many of the operations, practices, and structures imposed by their forebears. The framers also included no formal mechanism for amending the constitution, implying that this body of laws and statutes would operate $a d$ infinitum. The 1776 Constitution handicapped the power of the executive by permitting the General Assembly oversight of the executive office. The General Assembly elected the governor, who served three one-year terms, limiting his power and providing the governor little opportunity to check the power of the legislative branch. The legislature's election of the governor also meant the governor often acted as a puppet for the grandees, making him little more than a figure head. In one final gesture showcasing the ultimate power of the General Assembly over the governor, the legislature could pass legislation without obtaining the governor's signature via a simple majority. The subsequent legislation was not subject to executive veto, either. ${ }^{18}$

Though the governor remained under the watchful eye of the General Assembly, the position did include an important judicial privilege. The constitution empowered the governor to appoint justices of the peace to county courts, an important role considering that these local courts projected the state's power. These appointments came with an important caveat: the governor could only appoint those nominated by members already on the bench. As the majority of those sitting members came from prominent families, the appointment process worked to the advantage of these families, allowing them to perpetuate and consolidate power in the community. Furthermore, this process of appointing new judges allowed these prominent families to insulate themselves from public challenges to their power. ${ }^{19}$ One such family, the

\footnotetext{
${ }^{18}$ Francis Pendleton Gaines, Jr., "The Virginia Constitutional Convention of 1850-51: A Study in Sectionalism" (Ph.D. diss., University of Virginia, 1950), 32; Dickson Bruce, Jr., The Rhetoric of Conservatism: The Virginia Convention of 1829-30 and the Conservative Tradition in the South (San Marino, CA: Kingsport Press, 1982), 8-9. 19 Tarter, Grandees of Government, 108.
} 
Jacksons from Clarksburg, built an impressive network of patronage, jobs, land holdings, and local and state elected offices in the Northwest through this practice well into the mid-nineteenth century. ${ }^{20}$

Still, of the three branches of government, the legislative remained the strongest, a reflection of the distrust of monarchical figures and the continued perpetuation of grandees' power. The formula used to determine representation, the method of voting, and the requirements for voting all worked to solidify legislative power (and the elites they represented) while limiting the power of the disenfranchised. Indeed, all three measures worked to achieve the same end: to make sure that government and politics remained the purview of "civilized men, not for a horde of savages just emerging from an imaginary state of nature," as one noted conservative later commented. ${ }^{21}$ To limit the power this "horde of savages" could wield, representation in the state legislature favored the Tidewater region, the area where most elites resided. The state constitution allotted each county two representatives in the House of Delegates regardless of the county's white population or aggregate population of white and black residents. While on the surface this apportionment appeared equal, important demographic shifts following the American Revolution highlighted this apportionment's inherent inequality. Numerous Tidewater counties' population stagnated or declined as free white people and white families, along with their slaves, moved west and settled in the western part of the state or in fertile land opening beyond the Appalachian Mountains. ${ }^{22}$ This constant and steady migration increased the populations of western Virginia counties, including those in the Northwest. And as

\footnotetext{
${ }^{20}$ Matthew C. Foulds, "Enemies of the State: Methodists, Secession, and the Civil War in Western Virginia, 18451872" (Ph.D. diss., Ohio State University, 2012), 70.

${ }^{21}$ Proceedings and Debates of the Virginia State Convention of 1829-1830: to which are subjoined, the new constitution of Virginia, and the votes of the people (Richmond: S. Shepherd \& Co., 1830), 160. [hereafter cited as Proceedings and Debate]

${ }^{22}$ David Hackett Fischer and James C. Kelly, Bound Away: Virginia and the Westward Movement (Charlottesville: University of Virginia Press, 2000).
} 
this demographic shift continued, residents became increasingly aware of the political paradox of a minority ruling a majority. As one Monongalia County resident later grumbled, "a defect in the Constitution" authorized "one third of the free people...[to] rule the other two thirds of the people.”23 A governing minority flouted equality and democracy for white men while betraying the legacy of the American Revolution.

The declining population of eastern counties and the increasingly populous western counties captured Virginians' attention, including Thomas Jefferson, who ruminated on this disparity in his Notes on the State of Virginia. Using militia returns, Jefferson compared the population figures of Warwick County in southeast Virginia against Loudon County in northcentral Virginia. The dramatic population swings in both counties and subsequent political ramifications confirmed what Virginians believed: a minority residing in eastern Virginia controlled and benefited from the operations and structures of the state government. As Jefferson later averred, the "exclusion of a majority of our freemen from the right of representation is merely arbitrary, and an usurpation of the minority over the majority." 24 Although Warwick County had experienced a declining population in the preceding years, its representatives still wielded the same amount of political power as the increasingly populous Loudon County. When Warwick's delegates joined with other Tidewater delegates, their numerical advantage proved practically insurmountable, often at the expense of projects designed to develop the minds and natural resources of the state. A public education system, numerous internal improvements including canals, roads, and railroads, and greater development

${ }^{23}$ Monongalia Chronicle, December 31, 1825, 3.

${ }^{24}$ Niles Weekly Register, 26 (1824), 179. 
of the state's coal fields all faced immense opposition from this minority, with few projects garnering the state legislature's approval. ${ }^{25}$

Perhaps of all the statutes contained in the Virginia bylaws none garnered more scrutiny than the freehold requirement. A freehold represented the ownership of some quantifiable amount of land; its political significance, though, greatly outweighed its measureable quality. Virginia's colonial government first adopted the freehold requirement in 1670 as a way to strengthen the relationship between the colony's planters and landowners and the fledgling government. In return for financially and personally supporting the government, colonial legislators decreed that only propertied individuals could vote and hold public office, and that the freehold would be used to calculate representation. Small farmers, indentured servants, laborers, and other dependents not meeting the freehold requirement lost their voice in government. Proponents of this policy pointed to landowners' support of the government and, as land represented the source of wealth, legislation, taxation, suffrage, and political office, those with the most at stake deserved a stronger voice in politics.

Finally, advocates defended the freehold with an ideological justification. Propertied men represented the proper stewards of liberty and were best suited to perform the necessary civic duties required for the maintenance of the republic, supporters insisted. Such physical and economic independence allowed these men to insulate themselves from outside interests and

\footnotetext{
${ }^{25}$ A desire for a public education system and greater investment in internal improvements represent two of the salient issues that contemporaries and previous historians focused on when exploring the eventual schism between western and eastern Virginia. The works of Charles Ambler and Henry T. Shanks stress these issues. More recently, Sean Adams has shed light on the politics of coal in the Old Dominion, demonstrating that Virginia's leaders, through the economic and political systems, sought to preserve and protect established agricultural interests, often at the expense at other avenues of economic change, including coal production. What resulted in Virginia was what Adams calls a "zero-sum" style of politics that not only pitted regions against one another but often county against county, too. Ambler, Sectionalism in Virginia; Shanks, Secession Movement in Virginia; Sean Patrick Adams, Old Dominion, Industrial Commonwealth: Coal, Politics, and Economy in Antebellum America (Baltimore: Johns Hopkins University Press, 2004).
} 
voices. As a Clarksburg resident later proclaimed, the freehold requirement allowed freeholders to "remain beyond the reach of bribery and corruption." Alternatively, nonfreeholders "may be swept away by every favourite breeze." ${ }^{26}$ Ultimately, the health of the government and the future of the republic, defenders argued, depended on the freehold requirement. ${ }^{27}$

Within these grand pronouncements of protecting the republic, a latent current of distrust existed in the minds of freeholders about the intentions of their non-freeholder neighbors. For numerous freeholders, especially those in positions of power, non-freeholders appeared as an uncertain ally or a possible enemy. Freeholders worried that men like "A HOUSE KEEPER of Harrison County" would revolt against the ruling order or join forces with sympathetic freeholders and institute draconian legislation that could upset Virginia's hierarchical foundations. Land, slaves, material wealth, and raw power could all vanish from the hands of freeholders if such an apocalyptic scenario reached fruition. Nonfreeholders' numerical majority heightened such concerns for freeholders. When rumors of war swirled about Virginia in the mid-1670s, freeholders' concerns nearly became manifest, as nonfreeholders lashed out in protest. ${ }^{28}$ Although the freehold fluctuated in acreage requirement over the proceeding decades, the original purpose of limiting participation and centralizing power in the minority continued throughout the early nineteenth century.

Nonfreeholders often found freeholders' arguments and fears absurd. The increasing commodification of land and absentee ownership undermined freeholders' noble arguments about the inviolability and sanctity of land. ${ }^{29}$ Rampant debt, penury, and political corruption

\footnotetext{
${ }^{26}$ Clarksburg Intelligencer, July 10, 1824, 1.

27 Tarter, Grandees of Government, 59.

${ }_{28}$ Tarter, Grandees of Government, 71.

${ }^{29}$ Curtis, Jefferson's Freeholders, 55-56, 94, passim.
} 
among freeholders undermined freeholders' arguments of political independence and piety. ${ }^{30}$ Freeholders displayed similar reckless behavior during campaigns. As one newspaper sarcastically remarked, nonfreeholders should step aside in order to "give place to that drunk freeholder just behind you." 31 Though imbibing on alcoholic beverages remained widespread throughout the nineteenth century, inebriated freeholders weakened assertions about their alleged moral and political superiority. ${ }^{32}$ Despite such actions, the freehold remained, disenfranchising approximately forty-percent of eligible white men west of the Alleghenies. ${ }^{33}$ Housekeepers, renters, laborers, and other dependents, including “A HOUSE KEEPER of Harrison County," constituted nonfreeholders. This political marginalization frustrated nonfreeholders, who pondered when the American Revolution's legacy would finally be realized.

Reformers advocating for a revised constitution cited two more egregious flaws. One, voters cast their ballot viva voce. This method of oral balloting exposed voters to scrutiny, intimidation, and outright threats from neighbors. Further, viva voce balloting allowed politicians and local elites to persuade voters to support certain candidates through bribery and patronage, allowing powerful families to preserve their hegemony. Reformers grumbled that "dependent men went to the polls under duress" while "[o]nly those in independent circumstances could vote with entire freedom." 34 Reformers supported private ballots, insisting that this practice would shield voters from outside influences.

\footnotetext{
${ }^{30}$ Beeman, Varieties of Political Experience in Eighteenth-Century America, 66-67.

${ }^{31}$ Clarksburg Intelligencer, January 29, 1825, 3.

${ }^{32}$ W.J. Rorabaugh, The Alcoholic Republic: An American Tradition (New York: Oxford University Press, 1979).

${ }^{33}$ Robert Paul Sutton, "The Virginia Constitutional Convention of 1829-30: A Profile Analysis of Late Jeffersonian Virginia" (Ph.D. diss., University of Virginia, 1967), 259-261. While Sutton does not delineate the Northwest from the Trans-Allegheny, his figures suggest that the Northwest experienced a rate of disenfranchisement close to that of the entire region. Surprisingly, though, the Trans-Allegheny did not experience the highest rate of disenfranchisement. According to Sutton's figures, approximately half of voters in the Shenandoah Valley could not cast a ballot because they did not meet the freehold requirements.

${ }^{34}$ Hall, Rending of Virginia, 70.
} 
Reformers not only opposed how ballots were cast but also how frequently freeholders could vote in state elections. Freeholders were eligible to vote in each county in which he owned a freehold. ${ }^{35}$ With county elections often occurring on different days and occasionally lasting multiple days, it was not uncommon for some freeholders to cast multiple ballots. Older Tidewater counties' close proximity and smaller size complemented this policy, increasing easterners' political power. Western counties larger geographical size and rugged topography generally prevented trans-Alleghany freeholders from casting multiple ballots. While politicians stressed "one man, one vote" while campaigning, this phrase rang hollow for northwestern residents who witnessed what they considered a denial of their natural rights. ${ }^{36}$

The high rate of disenfranchisement in the trans-Alleghany, the preponderance of political power in the Tidewater, and West Virginia's founding in 1863 has caused subsequent historians to interpret Virginia politics through an east-west prism. ${ }^{37}$ In reality, no such clear demarcation existed. Prominent landed families and individuals in northwestern and western Virginia benefited from the current political system as much as Tidewater elites and often worked across the sectional divide to accomplish shared goals. For example, the General Assembly altered the method of electing the president from a district system to a general-ticket system. This seemingly arcane modification, championed by Thomas Jefferson, allowed elites to mute dissent and create the façade of a unified electorate. ${ }^{38}$ Elites on both sides of the mountains also used vast webs of patronage and their control of and access to the county courts to acquire

\footnotetext{
35 Tarter, Grandees of Government, 87-93.

${ }^{36}$ Curtis, Jefferson's Freeholders and the Politics of Ownership, 105.

${ }^{37}$ See, for example, Ambler, Sectionalism in Virginia and Shanks, Secession Movement in Virginia.

${ }^{38}$ Leonard L. Richards, The Slave Power: The Free North and Southern Domination, 1780-1860 (Baton Rouge: Louisiana State University Press, 2000), 59-60. Until 1800, Virginians chose presidential electors via the district system, allowing districts to act independently from one another and providing an outlet for dissent. In 1796, one district in Virginia chose electors for John Adams over those for Thomas Jefferson. In 1800, the Virginia General Assembly instituted the general-ticket system. This new method meant that the candidate receiving the majority of votes would receive the state's entire slate of electors.
} 
valuable information on available land. In western Virginia, this "buckskin elite” exercised hegemony over residents by establishing alliances with their eastern brethren and shielding themselves from public censure via the county court system. ${ }^{39}$ For example, the Jackson Family dominated northwestern politics through the middle of the nineteenth-century using the judicial system to accumulate wealth, land, patronage, political offices, and power across the Northwest. ${ }^{40}$ Such individuals and families felt little need to reform the political system to appease their disenfranchised and dissatisfied neighbors.

Political changes occurring outside Virginia, notably in other slaveholding states, amplified voices demanding reform. New slave states entering the Union in the late eighteenth and early nineteenth centuries democratized their political systems, flattening distinctions between white men and embracing the burgeoning democratic ethos. A Morgantown resident remarked that if he lived in another slaveholding state, such as Kentucky, he would possess "that most important privilege of freemen, the right of suffrage."41 Attempts to align Virginia with more democratic slaveholding states by adopting a new constitution, including one penned by Thomas Jefferson, encountered heavy criticism and defeat at the hands of the state legislature. ${ }^{42}$ Though the General Assembly passed laws abolishing primogeniture and entail, such moves failed to quiet the clamor for deeper and broader constitutional reform. ${ }^{43}$ In the Northwest, advocates for reform demanded a democratized state constitution that reflected changing demographic patterns and embraced what they believed were the natural consequences of the

\footnotetext{
${ }^{39}$ Williams, "The New Dominion and the Old," 337-340; L. Diane Barnes, "Avenues to a Market Economy: Harrison County, West Virginia, to 1860" (M.A. thesis, West Virginia University, 1995), 29-43.

${ }^{40}$ Foulds, "Enemies of the State," 70 and Jacob C. Baas, "John Jay Jackson, Jr.: His Early Life and Pubic Career, 1824-1870" (Ph.D. diss., West Virginia University, 1975).

${ }^{41}$ Monongalia Chronicle, January 14, 1826, 1.

${ }^{42}$ Tarter, Grandees of Government, 134. The new state constitution offered by Jefferson included a clause for universal male suffrage.

${ }^{43}$ Tarter, Grandees of Government, 133.
} 
American Revolution. Further, they hoped that the new constitution would recognize that men could stake their claim for political representation on their productive capacity of labor and their natural right to self-government. Incorporating these new dynamics into Virginia's constitution meant shifting the locus of political power from land to the individual, an uncertain prospect considering the innuendo and suspicion surrounding moves toward popular government. ${ }^{44}$

Popular manifestations advocating for constitutional and political reform emerged across the Northwest through various forms. In November 1795, a group of Monongalia County residents gathered to sign a petition addressed to the General Assembly to protest what the petitioners considered an aristocratic, inefficient, and broken government. The flaws with the current political system were numerous. Petitioners chided their rulers for not providing sufficient checks and balances between the branches of state government; questioned why the state legislature needed to meet so frequently and thus drain the state coffers; and argued that the method for electing senators should be changed, perhaps even instituting popular elections for the position.

While the operations of the state needed repairs, the ideological basis upon which these operations rested required a drastic reorientation. The petitioners reminded the legislature that "the people are the source of all legitimate power" and that the "equality of man" represented a ubiquitous sentiment among residents. Further, those currently excluded were "neither less virtuous, less wise, less experienced, nor less republican" than their forebears who fought in the Revolution. Many Virginians—notably those among the governing class—rejected such beliefs. "[T]hey are afraid to trust the people," the petitioners declared, a clear marker of the "language

\footnotetext{
${ }^{44}$ As will be explored in greater detail below, many opponents of reform pointed to, among other ill-fated developments, the French Revolution as a failure of popular government. Opponents believed that popular government or democracy meant "mob rule," and thus continued to profess that government worked best when political participation remained moored to property qualifications.
} 
of aristocracy." Indeed, these aristocrats sought to "degrade the mass of the people, and sacrifice public rights to private interest." To achieve political equality, the petitioners asked the legislative body to listen to the "will of the PEOPLE" and support a call for a constitutional convention to create a new constitution that redressed these grievances and embraced the legacy of the Revolution. ${ }^{45}$

The petition's first section stressing the state's dysfunctional political system reflected a central grievance for northwestern residents. Such grievances should not be surprising, as previous historians have used such evidence to portray a state riven by sectionalism. The petitioners' rhetorical strategy, though, reveals an important way northwesterners' attacked the ruling classes' ideological flaws. This exercise centered on degrading elites' republican virtue while demonstrating the public good nonfreeholders provided. While rulers supposedly sought to protect the common good, "private interest" constituted their primary concern. Further, an aristocracy by definition implied a class of men who possessed certain titles of nobility or positions of status and power; aristocrats were not avatars of the common man.

While the "mass of the people" exercised the same republican virtue as their ancestors, these men continued to find themselves under the dominion of aristocrats. It should not be surprising, the petitioners proclaimed, that "the legitimacy of the government itself [was] being doubted" because it rested on an unstable foundation. In order to be legitimate, a republican government needed the "constitutional authority" that could only be granted by the "majority" for the "majority" represented the true rulers of Virginia. Consequently, this proclamation meant that Virginians, notably the governing class, needed to embrace the widest possible definition of "the people" and a republic. A broader definition of "the people" meant recognizing all white

\footnotetext{
${ }^{45}$ Legislative Petition of Monongalia County, VA, November 12, 1795, Reel 127, Box 164, Folder 55, Library of Virginia, Richmond, Virginia. [hereafter cited as LV]
} 
men as equals regardless of wealth, holdings, or status; accordingly, a broader definition of "the people" should be reflected in a new form of government, one that constituted a hybrid of republicanism and democracy. ${ }^{46}$ Accomplishing both projects meant constructing new assumptions about power and legitimacy, a breakthrough in political thinking that would inevitably lead to conflict.

The immense task of altering the state's political operations failed to deter northwesterners, who continued to petition their government. Following the War of 1812, petitioners reminded the legislature of the military duty many signees performed during the conflict and their continued service in the local militia. But, Ohio County residents lamented, "not more than one half" of those who served in the war and currently served in the militia "were entitled to vote for their Rulers." Further, these disenfranchised militia men patrolled the community at night on the lookout for runaway or rebellious slaves while working during the day to keep the "roads and streets in good order \& condition." Meanwhile the enfranchised "are in a great measure exempt from any participation in those duties." 47 The exemptions enjoyed by the latter group physically burdened the community while elevating those men above their neighbors. It created, in the eyes of the petitioners, an artificial aristocracy that rang hollow with the memory of the Revolution, the recent military conflict, and the duties required in a republic. A nearly identical petition in neighboring Brooke County demonstrated that such thoughts received widespread currency in the Northwest. ${ }^{48}$

The petitioners touched on something deeper and more profound than the creation of an artificial aristocracy. In both counties, residents reminded their representatives of the powerful

\footnotetext{
${ }^{46}$ Legislative Petition of Monongalia County, VA, November 12, 1795, LV.

${ }^{47}$ Legislative Petition of Ohio County, VA, December 12, 1815, Reel 143, Box 188, Folder 12, LV.

${ }^{48}$ Legislative Petition of Brooke County, VA, December 12, 1815, Reel 27, Box 36, Folder 52, LV.
} 
gendered and symbiotic relationship between politics and military service. White men staked their claim to political representation and patriarchal power in the household on their ability to protect dependents in both spheres, as the public power of military service and politics translated to private power within the household. This ideological conflation between public and private power expressed in gendered terms promoted harmony between slaveholders and nonslaveholders across the South by cutting across class, socioeconomic, and political lines. ${ }^{49}$ Further, the "public performance" of politics allowed men to distance themselves from dependents who lacked the right to vote, including women. Once again, the "gendered virtues of manliness, honor, and character" were on full display for the community to witness. ${ }^{50}$ But in Virginia the deprivation of this public power threatened to undermine private power. And by depriving all white men, but especially those who performed military duties, of their full political representation, the governing class questioned those men's masculinity, their control over dependents, and ultimately their worth in a republic.

The Northwest's changing economic landscape further reminded residents of their political exclusion. While the majority of northwestern residents in 1820 claimed agriculture as their primary occupation, the number of those engaged in manufacturing and commerce surpassed other regions across Virginia, though substantially less than areas around Richmond. ${ }^{51}$ Still, the demand for political reform simultaneously increased as residents engaged in industrial

\footnotetext{
${ }^{49}$ Stephanie McCurry, Masters of Small Worlds: Yeoman Households, Gender Relations, and the Political Culture of the South Carolina Low Country (New York: Oxford University Press, 1995) and Hannah Rosen, Terror in the Heart of Freedom: Citizenship, Sexual Violence, and the Meaning of Race in the Postemancipation South (Chapel Hill: University of North Carolina Press, 2009), 2-7.

${ }^{50}$ Mark Voss-Hubbard, Beyond Party: Cultures of Antipartisanship in Northern Politics before the Civil War (Baltimore: Johns Hopkins University Press, 2002), 7.

${ }^{51}$ Freehling, Drift Toward Dissolution, 39; Shade, Democratizing the Old Dominion, 34-35; "Persons Engaged in Agriculture, Commerce, and Manufacturing, 1820, county-level, Virginia," University of Virginia Historical Census Browser, University of Virginia Geospatial and Statistical Data Center [http://mapserver.lib.virginia.edu/index.html] [accessed 4 December 2014] [hereafter cited as UVA Census Browser]
} 
labor, notably in Wheeling. Residents extolled Wheeling's development as an emerging commercial and industrial hub, praising the city's "inexhaustible mines of her hills, her manufactories, [and] the industry and enterprise of her citizens." ${ }^{52}$ The city's proximity to coal, limestone, and iron ore deposits fueled its industrialization during the nineteenth century while its location on the Ohio River facilitated the shipment of manufactured goods to western and southern markets. Wheeling's location also allowed it to emerge as the locus of the slave trade in the region. The completion of the National Road to Wheeling in 1818 connected the city to eastern markets while further cementing the city as an important commercial nexus. Iron foundries, nail works, cotton mills, flour mills, and coal mining in and around Wheeling provided employment and opportunity for residents, immigrants, and job seekers. While some jobs relied on plantation goods, most produced commodities unaffiliated with the plantercentered political economy. ${ }^{53}$

Wheeling's economic growth created an important variable in residents' pursuit of political reform. As Wheeling developed into an industrial-commercial center throughout the early nineteenth-century, the rise of new industrial and (later) professional classes such as mechanics and merchants reflected a significant shift away from the planter-centered political economy of previous generations. Further, the capricious and volatile labor market and economy decreased workers' economic stability and independence. Without fixed income, residents desired to fix their place within the body politic, a sentiment that increased as the Market

\footnotetext{
${ }^{52}$ Wheeling Compiler, July 8, 1829, 3.

${ }^{53}$ Wilma Dunaway, The African-American Family in Slavery and Emancipation (New York: Cambridge University Press, 2003), 21-22; L. Diane Barnes, "Urban Rivalry in the Upper Ohio Valley: Wheeling and Pittsburgh in the Nineteenth Century," Pennsylvania Magazine of History and Biography, 123, no. 3, (July 1999): 208-213; and Ambler, Sectionalism in Virginia, 117.
} 
Revolution unfolded. By obtaining political representation and equality, this new class of workers hoped to shield themselves from the Market Revolution's dislocating effects. ${ }^{54}$

In Ohio County, residents lamented that emerging classes of workers performed valuable work yet lacked political representation. Many felt "aggrieved" that the "right of suffrage is not sufficiently extended," most notably to the working-class and yeomen. "Laborers and agriculturalists, the industrious mechanicks, and the useful Merchants" all contributed to the wealth and stability of the state; yet they remained under the political rule of the "landholder (be his moral character what it may)." The planter-centered political-economy and the political structures based on that dynamic failed to adapt to Virginia's changing economic landscape. Those engaged in emerging new professions probably owned little or no landed property but still contributed to the general welfare of the republic through the productive capacity of their labor. Further, these "industrious" and "useful" workers were not exploitative, selfish individuals who would threaten the republic; landholders' capricious moral and political compasses constituted a republic's true enemies, reformers maintained. As the Northwest's industrial and commercial sector continued to grow throughout the antebellum period, the voices demanding reform would increase in size and gain various accents. ${ }^{55}$

Reformers' expressed their demands through various channels. Mass meetings, especially on the Fourth of July, presented some of the strongest language demanding reform while providing an important window into residents' worldview. Common among the scripted and volunteer toasts were those that stressed the global struggle for democracy, aligning Virginia's struggle for democratic reform with those occurring internationally. In Clarksburg in

\footnotetext{
${ }^{54}$ Charles Sellers, The Market Revolution: Jacksonian America, 1815-1846 (New York: Oxford University Press, 1991).

${ }^{55}$ Legislative Petition of Ohio County, VA, December 15, 1812, Reel 143, Box 187, Folder 107, LV.
} 
July 1824 , residents gathered in the town square and enjoyed the usual celebratory festivities, including a military parade, sermon, and banquet. After these festivities, the toasts began in earnest, officiated by, among others, Thomas P. Moore, a slaveholder. ${ }^{56}$ The scripted toasts extolled the memory of George Washington, the U.S. armed forces, internal improvements, and noted that "the Cause of the Greeks" and "Our Brethren of South America" remained locked in the same struggle for democracy that the United States endured. In Wheeling, gatherers also toasted the efforts of Ireland and Greece, along with the "Liberator of the South," Simon Bolivar. ${ }^{57}$ Virginians could take solace in knowing that their fight for democracy mirrored those around the world. Such pronouncements also steeled residents to continue the fight, aware that the tide of democracy would soon wash away tyranny.

Volunteer toasts touched on similar themes but also focused on pertinent state issues, notably constitutional reform. Paraphrasing Patrick Henry, one celebrant in Clarksburg proclaimed, "If to change [the constitution] be treason, may we all turn traitors." ${ }^{58}$ In Wheeling, one toaster prayed that a "constitution [based] on liberal principles" would "restore [Virginia] to her former glory." While the toaster failed to identify those "liberal principles," one can infer that political equality and popular sovereignty topped that list. ${ }^{59}$ Another Fourth of July celebration in Wheeling two years later echoed many of the same themes. One resident expressed his hope that an amended constitution and reformed political system would remove the "weight of a selfish oligarchy" and allow "her citizens [to] enjoy their equal and unalienable rights. ${ }^{\prime 60}$ The memory of the American Revolution informed residents' interpretation of

\footnotetext{
${ }^{56} 1820$ U.S. Federal Census: Harrison, Virginia; Page: 97; NARA Roll: M33_138; Image: 111 [http://search.ancestrylibrary.com/][accessed 25 August 2014]

${ }^{57}$ Wheeling Gazette, July 7, 1827, 3.

${ }^{58}$ Clarksburg Intelligencer, July 10, 1824, 2.

${ }^{59}$ Wheeling Gazette, July 7, 1827, 3.

${ }^{60}$ Wheeling Gazette, July 11, 1829, 2.
} 
Virginia's contemporary political paralysis but the means for reviving the state remained obvious. Virginians needed to recognize the natural consequences of the American Revolution and embrace a reformed political system that valued the political weight of all white men, the true "people" of the Commonwealth.

Fourth of July celebrations offered more than an opportunity to exalt the exceptional history of the United States. Indeed, one of the latent cultural aspirations of such gatherings centered on communal expression and solidarity. Residents from various socioeconomic, political, cultural, and ethnic backgrounds convened and debated politics, often doing so with an accessible vernacular. While a farmer or laborer attending the celebration may not have fully grasped the political minutia of constitutional reform, he probably understood politics when filtered through the prism of the American Revolution and when debated with neighbors. Reformers hoped to wield this common vernacular against the governing class to effect political change from the grassroots. Therefore, when residents spoke of "oligarchy" and "inalienable rights" during these democratic celebrations and meetings, these words carried tremendous political significance accessible to residents. ${ }^{61}$

The harmony expressed during meetings and Fourth of July celebrations overshadowed disagreements that commonly arose. Henry Clay and Andrew Jackson both received their respective toasts in one Wheeling celebration, for example. ${ }^{62}$ Another celebrant praised John Randolph, a vociferous opponent of democratic reform and supporter of the present ruling order. ${ }^{63}$ Such political fractures were common during the 1820 s, especially as national political parties emerged and mobilized voters. Yet one issue received nearly universal approbation from

\footnotetext{
${ }^{61}$ Mary Ryan, Civic Wars: Democracy and Public Life in the American City during the Nineteenth Century (Berkeley: University of California Press, 1997), 15.

${ }^{62}$ Wheeling Compiler, July 8, 1829, 3.

${ }^{63}$ Clarksburg Intelligencer, July 10, 1824, 2.
} 
northwestern residents: slavery. While home to fewer slaves than other regions of Virginia, the Northwest nevertheless held thousands of slaves and remained part of the largest slaveholding state in the country. ${ }^{64}$ Although sometimes not explicitly stated, the political issue of slavery always hovered around political discussions. Reformers' demands for a new constitution often contained assurances that democratizing the state would secure, not threaten, slavery.

To strengthen their arguments, reformers often recruited slaveholders to sway public opinion in favor of constitutional revision. In 1825, Monongalia County residents delivered a petition to the state legislature demanding constitutional reform. Among the signatures were Thomas Ewell and George Jenkins, the former owning three slaves and the latter owning one. ${ }^{65}$ Alongside their names were farmers such as Nathan Johnson, who lived in adjacent Harrison County and Monongalian Arby Pool, both of whom relied on family labor, not slaves, to farm the land. ${ }^{66}$ The signatures of Ewell and Jenkins manifest their beliefs and reformers' arguments that an amended constitution posed no threat to slave property. Though democratization would alter the state's operations and structures, slavery's status in Virginia's political constellation would remain secure. ${ }^{67}$

Some reformers expanded this argument, declaring that a democratized political system would tether eastern slaveholders' interests more tightly to western nonslaveholders. One Monongalia County resident reassured his eastern brethren that should that "internal foe, which forms the principal part" of the region's wealth revolt, the "Western mountaineers [will] rush down from their rocks, and roaring streams, to the help of their eastern brethren." ${ }^{68} \mathrm{~A}$

\footnotetext{
64 “1820 Slave Population, County-level, Virginia," UVA Census Browser [accessed 9 December 2014] Some of the notable northwestern county totals included Brooke with 383; Harrison, 569; Monongalia, 375; and Ohio, 419.

65 Ancestry.com [http://search.ancestrylibrary.com/][accessed 26 August 2014]

${ }^{66}$ Ancestry.com [http://search.ancestrylibrary.com/][accessed 26 August 2014]

${ }^{67}$ Legislative Petition of Monongalia County, VA, December 12, 1825, Reel 127, Box 165, Folder 101, LV.

${ }^{68}$ Monongalia Chronicle, December 3, 1825, 3.
} 
democratized state government would secure slave property and promote greater harmony among Virginians across sectional and political lines. Reformers likewise deflected arguments that their natural rights argument invariably extended to Native Americans, women, children, slaves, and free blacks. "Free negroes \& mullatoes," the author proclaimed, "never did, and never will [vote] in Virginia." ${ }^{69}$ Instead, allowing white men to exercise their natural right to self-government and building a state government that recognized that reality would secure racial boundaries. And as racial lines hardened, the institution generating that demarcation would become more secure as all white men would aid in its protection. The symbiotic relationship between democratic citizenship and an ardent commitment to slavery would reach full fruition.

Though reformers professed greater security for slavery and enlisted slaveholders to assist their push for constitutional reform, the special privileges that slaveholders, especially large slaveholders, commanded, remained open to scrutiny. Slaveholders often avoided serving in the local militia except when they served as officers, enjoying the lofty and prestigious position while leaving the drudgery of militia work to the "farmer, mechanic, \& the poor manthe bone and sinew of the country." Such a privilege led one observer to argue that the "aristocracy of the country...rest[s] with the man of wealth and the large slave holder." Morgantown, the editor of the Monongalia Chronicle wondered why the burden for maintaining local roads fell disproportionately upon the "poor man who...though his locks are whitening with age" still sent his "five or six sons" to repair dilapidated roads. An elder patriarch would certainly miss the labor his sons on the farm or around the house. The "slave-holder that has two slaves," though, could send out his slaves to work while keeping his sons at home. ${ }^{71}$ The

\footnotetext{
${ }^{69}$ Monongalia Chronicle, January 14, 1826, 1.

${ }^{70}$ Wheeling Gazette, May 2, 1829, 3.

${ }^{71}$ Monongalia Chronicle, August 26, 1826, 3.
} 
possibility existed that the poor man's sons would labor alongside African American slaves, a scenario fraught with indignity and shame for free white Virginians. The color line that supposedly demarcated freedom from bondage became blurred in such instances, leading many residents to openly question the privileges slaveholders enjoyed. Still, slavery remained immune from criticism; only the special benefits slaveholders received drew the ire of reformers.

While reformers carefully parsed their language concerning African American bondage, slavery's vocabulary represented a powerful language that underscored nonfreeholders' political inequality. A nonfreeholder in Wheeling wrote a lengthy missive excoriating the "aristocratical rulers of Virginia" for fastening the "yoke" around the "disenfranchised." Virginia's leaders controlled the "lives," "liberty," and "property" of nonfreeholders, governing without the "consent" of "the people." The moral was clear. The relationship that existed between freeholders and nonfreeholders mirrored the master-slave dynamic, and it was painfully obvious that nonfreeholders performed the role of the slave. Further, as a political slave, the nonfreeholder possessed no honor or voice and submitted to the direction of the freeholder. The lack of honor was especially embittering for white southerners whose culture placed a heavy emphasis on the public maintenance of honor. Without redress, the political "chains" that nonfreeholders wore would be tightened and passed down to posterity while the absence of honor would result in public emasculation and shaming. ${ }^{72}$ The threat of white slavery paralyzed white men with fear. Indeed, the disconcerting analogy between themselves and enslaved African Americans was anathema, the worst degradation a white man could suffer. And the threat of white slavery mocked notions of political equality, popular sovereignty, and racial

\footnotetext{
${ }^{72}$ Wheeling Gazette, March 28, 1829, 2; Bertram Wyatt-Brown, Southern Honor: Ethics and Behavior in the Old South (New York: Oxford University Press, 1986); and Nicole Etcheson, The Emerging Midwest: Upland Southerners and the Political Culture of the Old Northwest, 1787-1861 (Bloomington: Indiana University Press, 1996).
} 
boundaries. But a democratized state constitution could emancipate nonfreeholders from the political slavery they currently endured.

This increasing restlessness for political reform divided many elites. Thomas Jefferson, a sympathetic figure to many northwesterners and nonfreeholders, supported a more equitable form of representation. "The exclusion of a majority of our freeman from the right of representation," he lamented, "is merely arbitrary and an usurpation of the minority over the majority." The nonfreeholding majority felt the greatest pains of this political marginalization. ${ }^{73}$ The minority, Jefferson worried, constituted a homogenous body that, without a larger and more diverse voter and candidate pool, would reign similar to a king. ${ }^{74}$ James Madison's stance proved elusive. Although he had warned of oppressive majorities in the Federalist papers, he previously criticized the Washington administration for its coddling of financial elites at the expense of citizens. He worried that a similar cadre of elites would invariably bend the will of the state government to satisfy their needs. ${ }^{75}$ Madison also supported a call for a new constitutional convention to reform what he considered Virginia's "bad" constitution, and even cautioned new states from reproducing the Old Dominion's form of government. For immediate remedies, he proposed the popular election of the governor and greater independence for the judiciary system. Still, Madison expressed caution about constitutional reform, vacillating

\footnotetext{
${ }^{73}$ Niles Weekly Register 26 (1824), 179.

${ }^{74}$ Trenton Eynon Hizer, "'Virginia is now divided': Politics in the Old Dominion, 1820-1833” (Ph.D. diss., University of South Carolina, 1997), 171-173. In a letter to Samuel Kercheval, Jefferson elaborated on the reforms he supported. They included popular elections of governors and judges, equal representation in the legislature, "general suffrage," and revision of the state constitution as time warranted. See Shade, Democratizing the Old Dominion, 58. Also available online at: http://teachingamericanhistory.org/library/index.asp?document=459 [accessed 26 August 2014]

${ }^{75}$ Susan Dunn, Dominion of Memories: Jefferson, Madison, and the Decline of Virginia (New York: Basic Books, 2007), 162. Madison's stance on representation proved even more fluid during the 1829-1830 Constitutional Convention. He originally favored using the white basis to determine apportionment, but later recanted and supported the federal basis, thereby empowering the minority over the majority.
} 
between a proponent and one worried about the larger and possible unforeseen consequences of revision. ${ }^{76}$

Other elites cast askance at the more progressive ideas promulgated by Jefferson and Madison. Abel Parker Upshur and John Taylor of Caroline both passionately believed in the close relationship between slavery and political power. Democratic reform, Upshur insisted, inherently threatened slavery by placing the peculiar institution within nonslaveholders' power. Accordingly, any whiff of political change that threatened that power dynamic drew the scorn of both. ${ }^{77}$ John Randolph of Roanoke remained ever defiant against the democratic tendencies that emerged in post-colonial Virginia. He assailed the "pernicious falsehood" of egalitarianism found in the Declaration of Independence, declaring equality between white men a mere chimera. ${ }^{78}$ Further, he ardently defended slaveholders' political rights on both the national and state level. Attempts by the majority—whether represented by northerners or nonfreeholdersto interfere with slaveholders' property had to be dispatched. ${ }^{79}$

Eastern Virginians expressed many of the same concerns shared by Upshur and Parker. Residents of Essex County insisted that they were "perfectly content with their ancient institutions and most jealous and fearful of the spirit of innovation." The spirit of innovation that residents feared was democratic reform. Residents worried that embracing democratic reform would "disturb or put [our institutions] in...jeopardy." 80 In Louisa County, the same specter of democratic reform hung over the heads of its citizens. "Free men perceive no difference," they maintained, "in the acts of a single Tyrant and a numerous body of Tyrants." Majoritarian rule

\footnotetext{
${ }^{76}$ Dunn, Dominion of Memories, 151-152.

${ }^{77}$ Robert E. Bonner, Mastering America: Southern Slaveholders and the Crisis of American Nationhood (Cambridge: Cambridge University Press, 2009), 44-48 and Shade, Democratizing the Old Dominion, 62.

${ }^{78}$ Quoted in Freehling, Drift Toward Dissolution, 63.

${ }^{79}$ Dunn, Dominion of Memories, 160 and Nicholas Wood, "John Randolph of Roanoke and the Politics of Slavery in the Early Republic," Virginia Magazine of History and Biography, 120, no. 2 (Spring 2012): 106-143.

${ }^{80}$ Legislative Petition of Essex County, VA, December 8, 1825, Reel 48, Box 67, Folder 77, LV.
} 
frightened eastern Virginians, who feared the arbitrary and violent rule of mobs. The current model of government, these residents stressed, worked best to protect their interests and those of all Virginians. ${ }^{81}$

Though previous historians have interpreted the clamor for political reform as evidence of sectional discord, conservative voices emerged from western Virginia. Writing from his home in Staunton, Archibald Stuart recognized the momentum reformers generated in favor of amending the constitution. "The public feeling on this subject has become too strong to be resisted," he observed. "The people appear determined that the Minority in the state shall not continue to hold the reins of government." Along with embracing majoritarian rule, a new state constitution would invariably broaden suffrage, too. These changes "would sow the seeds of [our] destruction," Stuart predicted. "The rights then of those who own the country will be invaded by those who hold no part of it," he prophesized, "\& it will become in the progress to that state of things an objection to a Candidate to be either a Man of Talents or property." Stuart foresaw the bitter fruits of democracy. Social and political hierarchy would be extirpated, as those without power and property would seize both from the wealthy. Campaigning and electioneering would meet a similar fate. Those men best suited for political office - men such as Stuart and his ilk — would be shunned because they were not avatars of "the people." Instead, demagogues, political charlatans, and deceitful orators would seize power by duping uneducated and easily malleable voters. The fate of the republic hung in the balance, Stuart reasoned, compelling him to oppose reform. ${ }^{82}$

\footnotetext{
${ }^{81}$ Legislative Petition of Louisa County, VA, October 11, 1792, Reel 115, Box 148, Folder 29, LV.

${ }^{82}$ Archibald Stuart to unknown [William Wirt], 1829, item Mss1 St9102 e 1, Virginia Historical Society, Richmond, VA [hereafter cited as VHS]
} 
Even in the supposedly solid Northwest, conservatives voiced their opposition to democratic reform. One anti-reformer shared the same grave concern as Stuart, fearing that "the people" lacked the necessary political acumen required in a republic. The "people are too ignorant and corrupt to equalize their government," he explained. Permitting "the people" to govern the state would invariably debase the sacrosanct government handed down by the Revolutionary generation, inaugurating a new political and social order. Conservatives would "be hereafter oppressed, when put upon equality" with their poor, nonfreeholding, uneducated neighbors. And while propertied and wealthy men would continue to furnish the lion's share of tax revenue, their money would benefit those who paid few taxes. Conversely, the current government accurately prioritized interests and appropriately meted out political and financial wealth. Political and social institutions and relations worked harmoniously and for the greater good of all. Why, then, all this rancorous talk of reform, one anti-reformer wondered? ${ }^{83}$

While northwestern anti-reformers faced social and political intimidation and pressure when broadcasting their arguments, such opinions were not isolated incidents. Some opponents of reform echoed similar arguments as the one above, stressing that "the people" were powerhungry, myopic, and easily corruptible. The blather about a defective constitution emerged from "men without authority," demagogues who wished to drag Virginians through the same "oceans of blood" spilled during the French Revolution, one opponent insisted. These "men without authority" sought reform for one sole reason: to "freely...hold the bottle." ${ }^{\text {" }}$ Further, opponents deployed the racial argument, claiming that a democratized constitution would inevitably include African Americans. White men would be placed "on an equal footing, at elections \& in courts of justice, with free Negroes and Mulattoes," a haunting specter for white men. While reformers

\footnotetext{
${ }^{83}$ Monongalia Chronicle, September 3, 1825, 3.

${ }^{84}$ Monongalia Chronicle, November 12, 1825, 1-2. [emphasis in original]
} 
might receive their wish of political equality, it would arrive simultaneously with racial equality, too, anti-reformers averred. In one move, the pillars of hierarchy, patriarchy, and republicanism would be demolished, creating a world full of uncertainty and instability.

Serving as a backdrop to these debates were two unofficial reform conventions - one in 1816 and another in 1825 - that both convened in Staunton in the Shenandoah Valley. Representatives from thirty-five counties across the Commonwealth attended the 1816 meeting, including many men from the Northwest. ${ }^{85}$ The diverse nature of delegates prevented cohesion around specific reforms, but demands for white universal male suffrage and representation based on white population constituted the crux of their demands. ${ }^{86}$ Delegates couched such demands in Revolutionary language. Notably, representatives assailed the right of the minority to govern and legislate over the majority and that the archaic state constitution made a mockery of the American Revolution's legacy. ${ }^{87}$ The state legislature, hoping to appease reformers, responded by reapportioning the state senate by doubling the number of representatives from the west; created a Board of Public Works with the power to plan roads and canals; placed banks in Wheeling and Winchester to provide greater accessibility of capital; and devoted more money to internal improvements. ${ }^{88}$ While reformers accepted these changes, political harmony proved fleeting.

Delegates from across Virginia met once again in Staunton in July 1825, hoping for greater success than the previous convention. Approximately one-hundred delegates attended, and media coverage from prominent newspaper editors Thomas Ritchie and John Hampden

\footnotetext{
${ }^{85}$ For the 1816 Staunton Convention, Jesse Eddington and James Marshall represented Brooke County; John Staley and Thomas Wilson for Monongalia County; John Redd and Nicholas P. Hairston for Harrison County; and, Isaac Hoflier and Moses Chapman for Ohio County.

${ }^{86}$ For the proceedings of the 1816 Staunton Convention, see Niles Weekly Register 11 (1816), 17-23.

${ }^{87}$ Tarter, Grandees of Government, 178-179.

${ }^{88}$ Shade, Democratizing the Old Dominion, 59; Otis K. Rice and Stephen Wayne Brown, West Virginia: A History (Lexington: University Press of Kentucky, 1993), 93.
} 
Pleasants assisted delegates' push for constitutional revision. ${ }^{89}$ Delegates once again advocated for legislative apportionment based only on the white population, excluding African American slaves and land. Further, delegates demanded universal male suffrage. But divisions within the ranks of reformers stalled their efforts and anti-reformers exploited such cleavages. ${ }^{90}$ Still, many northwesterners remained sanguine that the "aristocracy of the legislature" could only temporarily delay democracy's arrival in the Old Dominion. Indeed, the "enlightened people" of Virginia "have long been sensible of...their power" to instigate political reform, and needed only to look to their Revolutionary ancestors for confirmation. ${ }^{91}$

While the putative representatives bickered, their constituents convened mass meetings across the state during the late 1820s. These meetings welcomed men regardless of class or political status, illustrating residents' widespread desire for reform and opposition to the present state constitution. Meetings in Richmond, Rockingham County, Louisa County, and Loudon County all witnessed significant gatherings of "non-freeholders, and others friendly to the extension of the right of suffrage." Residents declared that they would no "longer...tamely submit" to the chains of "political bondage" that the minority had forged around the majority. Should this form of political slavery continue, residents rhetorically asked. "Every man in the country must answer NO!!"92

In the Northwest, advertisements emphasized the meetings' inclusivity, pleading for all men regardless of political affiliation or personal fortune to mobilize and support a constitutional

\footnotetext{
${ }^{89}$ Shade, Democratizing the Old Dominion, 61. The newspaper editors' support for reform represented a mixture of heartfelt desire and political pragmatism. Both largely advocated constitutional revision as a means of being friendly to western citizens in the hopes of incorporating these new voters into political parties. One Virginian called Ritchie's Richmond Enquirer "the organ of the democratic-aristocracy of the land." Niles Weekly Register 27 (1825), 97.

${ }^{90}$ Rice and Brown, West Virginia, 93.

${ }^{91}$ Wheeling Gazette, January 8, 1829, 3 .

${ }^{92}$ Wheeling Gazette, February 28, 1829, 3; The Republican (Charles Town), May 16, 1829, 2 and May 23, 1829, 1.
} 
convention. In Ohio County, an advertisement requested all citizens to assemble at the courthouse to "adopt such measures in regard to the Convention as may be thought necessary.",93 A proposed meeting south of Wheeling requested the "non-freeholders of this election district" to assemble and "adopt such measures as they shall deem just and expedient" concerning a constitutional convention and the election of representatives to that gathering. ${ }^{94}$ Rather than limiting participation in these meetings to only freeholders, the meetings offered a forum for Virginians to discuss the current political system and mobilize for its alteration.

The demands for a constitutional convention reached critical mass during the 1827-1828 legislative session. Reformers across the state continued to wield the powerful language of liberty and equality while maintaining the steady flow of petitions and meetings. Newspaper editors, including Ritchie and Pleasants, published such appeals, helping to generate sympathy for political reform. Enough political pressure emerged that the General Assembly approved a call for a public referendum in 1828 on the subject of convening a constitutional convention the following year. Virginia freeholders approved the measure by a five-thousand majority, with a nearly unanimous Shenandoah Valley approving the call while approximately three-fourths of the Trans-Alleghany sanctioned the measure. Conversely, nearly seven-eighths of the Tidewater and one-half of the Piedmont rejected the call. But the votes of the populous West carried the day. The General Assembly passed an act summoning a convention for the following year, and required the revised constitution be submitted to voters for ratification or rejection. ${ }^{95}$

\footnotetext{
${ }^{93}$ Wheeling Gazette, February 28, 1829, 3.

${ }^{94}$ Wheeling Gazette, April 11, 1829, 3.

${ }^{95}$ Hizer, "Virginia is now divided," 186-187; Curtis, "Reconsidering Suffrage Reform," 103; and Shade, Democratizing the Old Dominion, 63-64. Apportionment for delegates favored the eastern elites, thus tilting the convention against the regions agitating for reform, including the Northwest.
} 
In the months preceding the constitutional convention, residents expressed hope that Virginia's political salvation was at hand. And, once again, Fourth of July celebrations provided the forum needed to express such hopes. At the Methodist meeting house in Wheeling in 1829, "a highly respectable audience of Ladies and Gentleman" articulated, heard, and cheered the usual patriotic toasts associated with the national holiday. One official toaster prayed that the members of the convention would form a "Constitution adapted to the character and permanent interests of Virginia." Following that toast, one reveler toasted "The West. - Yesterday a wilderness - to-day a country great in the improvements of art, and teeming with a wealthy and healthy population." The sequence of these two toasts represented an effort to emphasize the close relationship between a new constitution and embracing the democratic and progressive ethos emerging in the Northwest. A new constitution would unleash the immense potential found in western people and resources, ushering in a new era for the region and state. ${ }^{96}$

In nearby Elizabethtown, Fourth of July celebrants echoed similar sentiments. After the conventional patriotic toasts, revelers once again focused on the upcoming constitutional convention. They hoped that the "constellation of political talents and experience" to be gathered in Richmond would be equaled by a "liberality of sentiment." Immediately following that toast, those gathered lamented the "degraded" and "enfeebled" character of Virginia, a state that had long languished under the "weight of a selfish oligarchy." Still, residents expressed their profound hope that "the day of her political regeneration is drawing near." The coupling of the two toasts illustrated what residents considered the state's ailments and antidote. Only by embracing progressive and democratic principles could Virginians resurrect their political fortunes, reinvigorating residents and returning the state to its erstwhile lofty national status. ${ }^{97}$

\footnotetext{
${ }^{96}$ Wheeling Compiler, July 8, 1829, 3.

${ }^{97}$ Wheeling Compiler, July 22, 1829, 2.
} 
As northwestern residents awaited the convention in late 1829, they could not help but believe that Virginia's aristocratic government was in its death throes. History appeared to be moving in that direction. Internationally, the overthrow of monarchical rule in South America and parts of Europe demonstrated that the wave of representative democracy would inevitably sweep away all the vestiges of tyrants. Events closer to home gave greater hope. The emergence of Jacksonian Democracy and political parties appeared poised to usher in a new era of politics, where property, wealth, or birthright would no longer carry political weight. Southern slaveholding states, including Alabama and Mississippi, had already embraced democratic principles while not threatening slaveholders' property. Arguments extolling the compatible if not symbiotic relationship between slavery and democratic government gained increased currency across the South. Interpreting such events, countless Virginians and Americans increasingly believed that a representative democracy was the normative political model.

And for many northwestern Virginians, that political model transcended the current and archaic model that shackled peoples' energies and political rights. Principally, the structures and operations of the state appeared as a colonial relic. A malapportioned general assembly, strict suffrage requirements, a hegemonic legislative branch, and a flagrant omission of checks and balances illustrated to reformers that the state languished under an aristocracy. Equally egregious, this aristocracy seemed unwilling to listen to its constituents. Judge Lewis Summers of Kanawha County noted that upon receiving petitions demanding constitutional reform, the legislature did "nothing" with them except to "send them, with...recommendations to committees." The prospects for these petitions seemed dim at best. ${ }^{98}$ Armed with such

\footnotetext{
${ }^{98}$ Lewis Summers to George Summers, December 6, 1828, Box 1, Folder 1, Lewis and George W. Summers Papers, A\&M 1791, West Virginia and Regional History Collection, West Virginia University, Morgantown, WV [hereafter referred to as WVRHC]
} 
evidence, northwestern residents assailed the state's conservative structures and operations and the aristocratic men who perpetuated them. These aristocrats made a mockery of the memory of the American Revolution, rejecting equality and self-government. Only by embracing democratic principles could the state be set aright.

The petitions, Fourth of July celebrations, letters, and public meetings reveal not only the grievances northwesterners possessed but also the workings of a dynamic and flexible political culture. Nonfreeholders petitioned the state government demanding redress, signing their names beside men who possessed landed and human property. In Brooke County, three residentsAndrew Young, Roger Hill, and Thomas Allison—all signed a petition demanding a new constitutional convention to fix the inadequacies in the present constitution. None of these men owned property ${ }^{99}$ Further, men (and women) aired their hopes and aspirations during meetings and Fourth of July celebrations, cheering toasts and rubbing shoulders with their neighbors. Fourth of July celebrations and political meetings welcomed men of all political stripes and status, allowing all assembled to converse and debate. The burgeoning print medium allowed men like "A HOUSE KEEPER of Harrison County" to publish a letter excoriating the conduct of an elected official. While Virginia's official political sphere only permitted propertied men and men of wealth, the broader political sphere welcomed all white men (and women) regardless of property, birthright, or wealth. In essence, Virginia's system of government appeared rigid yet flexible, static yet dynamic, tethered to the past while showing glimpses of its possible future. But reform-minded residents and their representatives wanted a full embrace of democratic principles, structures, and operations, and the most effective means of achieving such dramatic change started with constitutional reform.

\footnotetext{
${ }^{99}$ Legislative Petition of Brooke County, April 29, 1816, Reel 27, Box 314, Folder 2, LV.
} 
Chapter 2: Reformers' Victory: the 1829-1830 Constitutional Convention

By April 1830, the constitutional convention that had assembled in Richmond the previous October had accomplished its task. Delegates had approved a new constitution and submitted it to voters who would shortly ratify it by a comfortable ten-thousand vote margin. ${ }^{1}$ While the new constitution received nearly universal acclaim east of the Blue Ridge Mountains and warm support in the Shenandoah Valley, its passage met with widespread resistance in the Northwest. Residents mobilized en masse against this new body of laws, decrying the "aristocratic" principles that shaped the document. The new constitution, according to these residents, perpetuated the constitutional inequalities that plagued the state under the previous constitution. The hope that residents' expressed prior to the convention had turned to bitter disappointment.

Northwestern residents lashed out in disbelief and anger. Editorials, meetings, correspondence, and extralegal political action illustrated residents' disapproval of the constitution. In Monongalia and Preston counties, "Many Non freeholders" published a letter in the local newspaper addressed to other nonfreeholders in the region. Angry about their continued political exclusion, these nonfreeholders interpreted their status in the body politic as akin to African American slaves. Nonfreeholders languished as "political slaves...journing in a land not ours" while performing as "servants of the Noble Lords of this land." Adding to residents' "degraded and servil condition" were rumors that the eastern "landholding party" supported "the rejection of the new Constitution because their power is not adjusted to please them,--forgetting us altogether." The authors, apoplectic about such political manipulation, constructed a plan to demonstrate that though they remained "Bondsmen" they would publicly

\footnotetext{
${ }^{1}$ Bruce, Rhetoric of Conservatism, 67-68. The official vote tally was 26,055 for ratification, 15,563 against.
} 
express their frustration. "[W]e feel proud," these men confidently stated, "that at least two hundred and fifty of us will be at liberty to come to the polls in this county and stand up erect, and speak for ourselves." Though disenfranchised, these men believed their presence, rhetoric, and actions around the polls would generate sympathy among voters. While the new constitution lacked democratic reforms, these men would manifest the democratic sentiment that burned brightly in their hearts and minds. ${ }^{2}$

The disappointment expressed by "Many Non Freeholders" reflected their disbelief that delegates adopted few, if any, democratic reforms. Legislative apportionment in both houses continued to favor eastern Virginians. This malapportionment continued to underrepresent northwesterners and ensured that state funding for internal improvements or a public school system would remain uncertain. While the new constitution extended the right of suffrage, the extension appeared modest, falling well short of universal male suffrage. The state legislature would continue to appoint government officials while prospective politicians still had to possess a freehold, too. The county court house system remained intact, perpetuating prominent families' program of consolidating power through patronage and land acquisition. Virginia's constitution appeared to have undergone few revisions.

Numerous northwesterners panned the new constitution. Residents' energy and optimism contained in editorials, Fourth of July speeches, meetings, and legislative petitions leading up to the convention seemed wasted. Though voters could vote against the proposed constitution, reports across the state strongly suggested that its ratification was a fiat acompli.

Northwesterners would continue to languish under a constitution that extended special privileges and powers to a certain class of individuals, bestowing increased representation, an insulated

\footnotetext{
${ }^{2}$ The Republican Monongalia \& Preston Advertiser, April 6, 1830, 3. [emphasis in original]
} 
court system, and a limited electorate to men determined to consolidate political power at all costs. The constitution's lack of a formal amendment mechanism increased residents' disappointment and anger.

Previous historians of the 1829-1830 Virginia Constitutional Convention explain the outcome as a defeat for democratic proponents and a victory for reactionary conservatives. Frequently, this body of historiography posits the convention as a manifestation of sectionalism and a harbinger of eventual dismemberment for the Old Dominion and the nation over the issue of slavery. ${ }^{3}$ One northwestern historian contended that "the people of West Virginia replied" to this convention, along with other numerous injustices, in their refusal to support eastern Virginians' secession movement in $1861 .{ }^{4}$ Another contemporary historian agreed, declaring that the constitution ratified in 1830 "sow[ed] the seeds of injustice and distrust which bore fruit in later years."

Modern historians have generally agreed with these previous interpretations. Conservative eastern planters, wary of democratic reform and fearful for their slave property, maintained their control of the state government, refusing to embrace the democratic principles championed by western nonslaveholders. This debate over slavery foreshadowed the national debate that would take place thirty years later. And though some historians have disagreed over the convention's sectional nature or slavery's centrality to the debates, the consensus persists that conservatives' overwhelming interest in slavery convinced enough delegates to defeat democratic reformers. For these historians, the convention represented a counterrevolution

\footnotetext{
${ }^{3}$ For this classical interpretation, see Ambler, Sectionalism in Virginia and Shanks, Secession Movement in Virginia. ${ }^{4} \mathrm{Hu}$ Maxwell, History of Monongalia County (n.p., [1900?]) 330.

${ }^{5}$ Henry Haymond, History of Harrison County, West Virginia: From the Early Days of Northwestern Virginia to the Present (Morgantown: Acme Publishing Company, 1910), 245.
} 
against the democratic forces that threatened to overtake the government and threaten chattel slavery. ${ }^{6}$

As Christopher Michael Curtis has recently argued, though, historians' preoccupation with the convention's refusal to embrace democratic reforms obscures the important ideological, political, and practical changes manifest in the new constitution. Specifically, seemingly minute and modest changes made to suffrage requirements accelerated the process of converting Virginia into a slaveholding democracy. While the traditional basis of the freehold rested on its acreage and its inherent association with republican ideology, the new constitution redefined the freehold in terms of its commercial value. ${ }^{7}$ By removing the freehold from its classical republican moorings, Virginians embraced the new political and economic context rapidly unfolding around them.

But this important change did not mollify many northwesterners. In the decades leading up to the convention, the majority of northwesterners passionately supported universal white male suffrage. Allowing all white men to vote, proponents argued, accurately reflected their interpretation of the American Revolution, helped secure private and public power for these

\footnotetext{
${ }^{6}$ Dickson D. Bruce, Jr., argues that slavery was part of the larger constellation of conservatism, stating that slavery constituted one plank of conservatives' defense during the 1829-1830 Constitutional Convention. Alison Goodyear Freehling and William W. Freehling contend that the convention represented a white, slaveholding community divided over democratic reforms and the future of slavery. These debates in Virginia mirror those that would later divide the nation. Alison Freehling, Drift Toward Dissolution and William W. Freehling, The Road to Disunion: Secessionists at Bay, 1776-1854. Both authors infer that western delegates and residents believed that slavery and democracy for white men were irreconcilable, but, as will be demonstrated, many northwestern residents and delegates lived comfortably with slavery, even if they questioned its economic value and congruity with religious and patriotic themes. William Shade has offered a useful center-periphery interpretation of the constitutional debates, helping to move beyond the east-west dichotomy that has shaped this body of historiography. Still, Shade argues that the new constitution was "antediluvian" and represented a "triumph of traditionalism." Shade, Democratizing the Old Dominion, 70. Sean Wilentz, in his seminal work, argues that "undemocratic slaveholders...triumphed" in defeating reform efforts and preserving their power. Wilentz, Rise of American Democracy, 345.

${ }^{7}$ Christopher M. Curtis, "Reconsidering Suffrage Reform in the 1829-1830 Virginia Constitutional Convention," Journal of Southern History, 74, no. 1 (February 2008): 89-124 and Curtis, Jefferson's Freeholders. See also Tarter, Grandees of Government, 186.
} 
white men, and rightfully validated the "common man" shibboleth of Jacksonian Democracy. The new suffrage requirements, however, fell woefully short of reformers' desires. This defeat in the convention, coupled with failed reforms of legislative apportionment, popular elections of government officials, and the county court system, embittered residents who believed their failure rested at the feet of eastern planters and slaveholders determined to slay "the demon of Reform" and protect their chattel at all costs. ${ }^{8}$

This perception that eastern slaveholders cared more about their African American slaves than equality with their white neighbors had profound and lasting consequences on intrastate sectional relations, the formation of political parties, the cultural debate over immigrants, and relations between neighbors. In the Northwest, these consequences possessed special import, as the region would become a flashpoint for these developments over the next four decades, embroiling residents in pitched political and cultural battles. But the importance of the convention went deeper than these issues. The convention's denouement and the new constitution did more than crystallize the perception that eastern slaveholders valued their slaves more than white equality. Indeed, the changes manifest in the new constitution presented the possibility that slaveownership and a racially based democratic polity could determine republican citizenship and provide the foundation for Virginia's republican government. Virginians' counterrevolution in 1830 protected slavery by paving the way for a modern slaveholding democracy.

As northwestern residents looked toward the upcoming constitutional convention set to convene in October 1829, many expressed optimism that deep and profound political change was imminent. Some argued that the august body of delegates set to assemble in Richmond would

\footnotetext{
${ }^{8}$ Hugh Blair Grigsby, "Sketches of Members of the Constitutional Convention of 1829-1830," Virginia Magazine of History and Biography, 61, no. 3 (July 1953): 320.
} 
lead the state out of political darkness and toward the light of democracy. "What good may we not anticipate," one Fourth of July toaster in Wheeling boldly proclaimed, "when Madison, Monroe, and Marshall are at the helm." Along with former presidents James Madison and James Monroe and sitting Supreme Court Chief Justice John Marshall, the assemblage included Governor William Branch Giles and the state's two senators, John Tyler and Littleton W. Tazwell. The gathering of such intellectuals and Founding Fathers, combined with the national march of Jacksonian Democracy, convinced residents that their long political suffering would soon end.

Northwestern residents also placed great hopes in their delegates to the convention. Those delegates included Alexander Campbell, an evangelical minister and Christian reformer, and Philip Doddridge, a lawyer and outspoken proponent of democratic reform. Both men hailed from Brooke County. Eugenius M. Wilson, a merchant and erstwhile Federalist, and Charles S. Morgan, both Monongalia County residents, joined Campbell and Doddridge in representing the northwestern counties of Ohio, Tyler, Brooke, Monongalia, and Preston. ${ }^{10}$ Even before the convention's opening, though, western delegates' numerical disadvantage threatened to derail their hopes of consummating a democratic constitution. The constitutional convention bill passed the previous year allotted representation on senatorial districts, where eastern Virginians held a distinct advantage. ${ }^{11}$ Still, northwestern residents and representatives remained aplomb. "The friends of the Convention appear to be contented with the progress which they have made towards reforming the state government," a Wheeling newspaper editor reported. ${ }^{12}$

\footnotetext{
${ }^{9}$ Wheeling Compiler, July 8, 1829, 3.

${ }^{10}$ Northwestern delegates served in different subcommittees during the convention. Alexander Campbell served on the judicial committee; Philip Doddridge on the legislative committee; Charles Morgan on the executive committee; and, Eugenius Wilson on the committee that considered the Virginia Bill of Rights and other issues brought up during the convention.

${ }^{11}$ Tarter, Grandees of Government, 179.

${ }^{12}$ Wheeling Compiler, July 15, 1829, 2.
} 
Delegates commenced work on October 5, 1829. As the convention began, the cultural differences between northwestern delegates and their counterparts from beyond the Blue Ridge Mountains quickly became manifest. Tidewater delegates, some of whom claimed the dignified status as members of the First Family of Virginia, arrived with powdered wigs, expertly tied cravats, and knee britches and silk stockings that complemented their attire. Such men looked the part of eighteenth-century aristocrats and classical republican government. Western and northwestern delegates, in contrast, resembled the hardscrabble environment from which they traveled. They arrived with disheveled hair, ties askew, and wearing homespun (and often mismatched) clothes. While Tidewater gentlemen traveled upon purebred horses (and, in the case of John Randolph of Roanoke, from imported English horses and carriages), western delegates descended from ragged and ill-bred horses that displayed the wear and tear of the journey across the mountains. ${ }^{13}$ These "uncouth looking" men, often scions of immigrants, lacked the "bland and polish manner belonging to the South," a distinction that became manifest when compared to their Tidewater colleagues. ${ }^{14}$ But northwestern delegates wore these distinctions with pride. While their fellow delegates from beyond the Blue Ridge embodied aristocracy, they embodied democracy.

The differences in delegates' clothing reflected differences in their speech patterns. Contemporaries often remarked at the "bold" and "eloquent" voices emanating from Tidewater and other conservative delegates as they "strove manfully against" reform measures. ${ }^{15}$ Their voices reflected their generally pure English heritage, education, and training in classical theories

\footnotetext{
${ }^{13}$ Freehling, Road to Disunion: Secessionists at Bay, 171. Contemporaries often characterized many conservative Tidewater delegates' fashion as "antique," further noting that these men had their "head powdered profusely every morning." This fashion and routine presented a sharp departure from the ragged and sometimes crudely dressed western delegates. Grigsby, "Sketches of Members of the Constitutional Convention of 1829-1830," $322,331$. ${ }^{14}$ Quoted in Merrill D. Peterson, Democracy, Liberty, and Property: The State Constitutional Conventions of the 1820s (Indianapolis: Bobbs-Merrill Co., 1966), 295.

${ }^{15}$ Grigsby, "Sketches of Members of the Constitutional Convention of 1829-1830," 320.
} 
of government, politics, political science, and philosophy. The voices emanating from northwestern delegates, specifically Philip Doddridge, often registered as unintelligible because of thick Scotch Irish accents. ${ }^{16}$ Reformers shot back, arguing that the "English way" of electing politicians inexorably led to the "English way of speaking to them."17 The diversity of political and linguistic accents, reformers argued, was one marker of a new political and social context where men no longer needed a freehold to vote or express deference when talking to politicians.

For reformers, the "English way" of structuring politics and relations between governors and the governed appeared as vestiges of colonial and aristocratic rule. Simply put, the "English way" was incongruous to this new political age. Reformers, hoping to fully inaugurate this new political age, aimed to remove other relics of colonial and aristocratic rule. Eugenius Wilson of Monongalia County wondered aloud about the effects of including a statute in the proposed constitution that would "stamp the seal of perpetual disenfranchisement" for those Virginians who engaged in dueling. ${ }^{18}$ Dueling, a gentleman's custom used to defend a man's honor and reaffirm social hierarchy, had faded in popularity but still retained a certain following among culturally orthodox planters and social and political elites. ${ }^{19}$ Other delegates commented on the measure and recommended the matter to the General Assembly, but Wilson's later tacit endorsement suggests a real cultural divide between northwestern delegates and their Tidewater counterparts. Delegates at the convention not only had to contend with diverse political principles; they had to navigate equally diverse cultural understandings that generated and shaped those political principles.

\footnotetext{
${ }^{16}$ Freehling, Road to Disunion: Secessionists at Bay, 171.

${ }^{17}$ Proceedings and Debate, 390.

${ }^{18}$ Proceedings and Debate, 780.

${ }^{19}$ Wyatt-Brown, Honor and Violence in the Old South, 142-153.
} 
As the debates unfolded in Richmond, representatives quickly found themselves clashing over two divisive issues: whether or not to expand suffrage and addressing malapportionment in the state legislature. On the former issue, northwestern representatives agreed that suffrage must expand beyond the archaic freehold requirement. ${ }^{20}$ Alexander Campbell argued that the freehold represented "as great an uncertainty as can be well conceived," finding the whole edifice upon which Virginia's system of government rested as "precarious."21 Eugenius Wilson found the freehold equally distasteful. Wilson exclaimed that it was "absurd and unjust" to base citizenship on a "fixed number acres of land, because of the inequality of the value of land." Wilson, acutely aware of land commodification and absentee ownership, especially in the TransAlleghany region, believed that the value of land was "too fluctuating, and its tenure too uncertain" to measure a person's attachment to the community. Confronted with the realities of a market society, he averred, Virginians required a different litmus test for republican citizenship. $^{22}$

But if the convention expunged the freehold requirement from the constitution, what would replace it? Or, as Wilson asked, "What test shall we apply?" to determine one's attachment to the republic. ${ }^{23}$ Here delegates differed, a key example of the fluid coalitions that hampered reformers' efforts. Alexander Campbell, who later founded the Disciples of Christ, believed that the Old Testament provided delegates with a blueprint for expanding suffrage. He argued that the "God of Israel first proposed a social compact" called a Berith in Hebrew; when translated, the Berith was "precisely equivalent to our English word Constitution." After the

\footnotetext{
${ }^{20}$ For this discussion of suffrage, I am indebted to Christopher Michael Curtis and his findings and interpretations in Jefferson's Freeholders, 102-114.

${ }^{21}$ Proceedings and Debates, 386.

22 Proceedings and Debates, 351, 352.

${ }^{23}$ Proceedings and Debates, 351.
} 
Israelite leaders wrote the Berith, they "submitted to every man on the muster roll of Israel."24 The political implications were clear. All men-not just landowners, religious clergy, or the governing class — voted to ratify or reject this constitution. Accordingly, Campbell offered an amendment for extending the right of suffrage to "every free white male of the age of twenty-two years, born within this Commonwealth." ${ }^{25}$ His plan to expand suffrage based on age and residency represented the most democratic plan offered during the convention; moderate and conservative delegates deemed it too radical and dismissed it.

Eugenius Wilson of Monongalia County spoke highly of the connection between natural rights and political participation. He maintained that "Nature, or Nature's God rather, had conferred certain original rights upon man." Foremost among these rights was the "right of appointing our own agents." The argument that all white men possessed a natural right to selfgovernment largely reflected his and other reformers' beliefs that the American Revolution had wiped away the vestiges of aristocratic rule and ushered in the rule of the "common man." But Wilson could not completely shake the belief that Virginians needed to demonstrate their attachment to the Commonwealth, a reflection of rampant absentee ownership and land speculation in western Virginia. His proposal increased those eligible to vote but was more modest than Campbell's proposal. Under Wilson's plan, free white males who had resided in the Commonwealth for a minimum of two years, paid taxes during that election year, satisfied military or militia obligations, and fulfilled any road service requirements would be eligible to vote. ${ }^{26}$ Those who shared the burdens of government, he maintained, should enjoy the franchise. His plan eschewed property qualifications for suffrage, finding the capricious market value of

\footnotetext{
${ }^{24}$ Proceedings and Debates, 388.

${ }^{25}$ Proceedings and Debates, 386.

${ }^{26}$ Proceedings and Debates, 353.
} 
property too unstable a foundation. But the proposal still proved too radical for many moderate and conservative delegates, meeting the same fate as Campbell's proposal.

Other northwestern delegates looked to other slaveholding states for guidance on expanding suffrage. Monongalian Charles Morgan argued that Virginia should align itself with the other slaveholding states that had democratized their constitutions to include liberal suffrage requirements and direct election of government officials. Morgan offered a synopsis of each slaveholding state's constitution, noting residency, age, property, or other requirements needed to vote. Morgan's efforts were more than a simple civics lesson. Rather, he believed that these constitutions conclusively illustrated "that the principle of General Suffrage is neither new nor dangerous." 27 These slaveholding states had broadened the franchise (and many had equalized representation, too) without endangering their chattel, compromising private property, or inaugurating civil anarchy. Slaveholders and nonslaveholders in such states possessed similar political interests and worked harmoniously to protect those interests. Only Virginia and North Carolina refused to follow their fellow slaveholding states.

Morgan's proximity to Ohio and Pennsylvania - two nonslaveholding states that operated with more democratized constitutions than Virginia—strengthened his argument. "[My constituents] see and know the benefits of General Suffrage on society," Morgan insisted. Indeed, the nearly daily economic, political, and personal interactions between northwesterners and residents in Ohio and Pennsylvania confirmed the lack of political rights Virginians enjoyed compared to other states. ${ }^{28}$ And as the Northwest followed a similar economic trajectory as that of Ohio and Pennsylvania, Morgan believed that the voices emanating from northwestern laborers would only increase in intensity and volume. Those white men who labored in the

${ }^{27}$ Proceedings and Debate, 379.

${ }^{28}$ Proceedings and Debate, 381. 
fields, shops, and manufactories "constitute the great mass of actual productive labourers of the State" and deserved political representation. These men manifested the productive capacity of labor, Morgan maintained, and offered more to the Commonwealth than indolent aristocrats adorned with powdered wigs who subsisted off of slave labor. ${ }^{29}$ Alexander Campbell agreed with his colleague. The manual labor required of and performed by western Virginians ensured that their "Republican principles" remained "pure and uncontaminated." On the other hand, eastern Virginians, Campbell remarked, owned "negroes" who "fan[ned] them to sleep," strongly suggesting that the lack of physical labor made such men not only physically weak and effeminate but politically enfeebled, too. ${ }^{30}$ Manual labor not only promoted masculinity in the public and private spheres for white men but ensured a hearty citizenry capable of protecting the republic.

Morgan's support for expanded suffrage and democratic reform reflected a different understanding of politics and government than what conservative delegates understood. Opponents of suffrage reform feared that an enlarged electorate comprised of propertyless men, drunkards, paupers, and other degraded and dependent classes led inexorably to "mobs, confusion, and turmoil at the polls." ${ }^{31}$ Noted conservative Benjamin Watkins Leigh reminded the convention that every state that had embraced the "extremes of democracy" soon devolved into "licence and anarchy." 32 Where conservatives perceived chaos, though, Morgan interpreted a healthy democratic society. Morgan conceded that when "many thousands of persons are brought together upon election days, there will be disputes, and sometimes turmoils." But delegates should embrace such displays. "These disputes only serve to show," he declared, "that

\footnotetext{
${ }^{29}$ Proceedings and Debate, 381-382.

${ }^{30}$ Proceedings and Debate, 119.

${ }^{31}$ Proceedings and Debate, 382.

${ }^{32}$ Proceedings and Debate, 394.
} 
the body politic is in a good and healthy condition; that it has energy and power." While eastern conservatives and opponents of reform preferred the "cold calm" of present elections "where few men dare express opinions on the public affairs," democratic elections meant that "all are free to discuss the affairs of Government." 33 Indeed, the arguing, bantering, debating, and politicking that occurred during elections showcased democracy in action. For during these interactions citizens offered their respective political interpretations, negotiated these understandings, and arrived at an accord that ultimately reflected the will of the majority. The "cold calm" displayed during current elections signaled widespread apathy and disinterest and permitted political manipulation by a vocal minority. The will of "the people" could not be accurately ascertained from elections. Morgan hoped that the inauguration of democratic reform would revitalize the state and the people and usher in dynamic and universal participation.

Morgan's interpretation of democracy reflected the growing leviathan of Jacksonian Democracy, a nascent movement that encompassed reforming constitutions, flattening distinctions between white men, and inaugurating a more raucous form of popular politics. Opponents of expanding suffrage specifically and Jacksonian Democracy generally considered northwesterners' arguments rubbish. Conservative Benjamin Watkins Leigh considered democratic principles, including the "Circuit Court System" and "Universal Suffrage," as a northern "plague" that threatened to sicken the body politic. ${ }^{34}$ Leigh's epithet of "plague" was revealing. With the causes of many contagious diseases still unknown in the nineteenth-century, Americans feared the unpredictability, rapidity, and arbitrariness with which illnesses struck. Leigh's figurative equation of a plague and democratic reforms, therefore, sought to refute reformers' ideological motivations, for these reforms, like contagious diseases, possessed no

\footnotetext{
${ }^{33}$ Proceedings and Debate, 382.
}

${ }^{34}$ Proceedings and Debate, 407. 
political agenda nor could they control their own actions. ${ }^{35}$ These democratic reforms, like "influenza" or "small-pox," struck randomly and would ravage Virginia's body politic. Further, the "plague" of democratic reforms emerged not from the ideals of the American Revolution or the context of Jacksonian Democracy; rather, they represented a dangerous and frightening northern outbreak that sought to replicate the heathen northern milieu on southern soil. Leigh proposed a simple solution to this malady. Stop the madness of democracy before it infected Virginia by maintaining the current power structure, thereby quarantining the body politic from nonfreeholders and other dependents who transmitted such "plague[s]."

Other opponents of reform spoke fondly of the freehold as the only proper and secure source of civic security and tranquility. Philip Norborne Nicholas, a Richmond banker, found little wrong with the freehold requirement and limiting suffrage to landholders. Nicholas railed against the idea that "[s]uffrage is derived from nature," arguing that the "lasting ownership of the soil of the country... is the best evidence of permanent attachment" to the commonwealth and thus afforded the best means for determining suffrage. ${ }^{36}$ John Randolph of Roanoke spoke forcefully against any suffrage or representation proposals that he believed would "divorce property from power." ${ }^{37} \mathrm{He}$ feared that proposals to expand suffrage beyond its current requirements would result in "bondage" for him and his ilk, as nonfreeholders would exercise limitless power over property. Randolph believed that the current constitution correctly distributed political power and rightly recognized the immense political weight that property, whether landed or human, exerted. For Randolph, the "pernicious falsehood" of egalitarianism promulgated by reformers misinterpreted the memory of the American Revolution and seemed

\footnotetext{
${ }^{35}$ Ashli White, Encountering Revolution: Haiti and the Making of the Early Republic (Baltimore: Johns Hopkins University Press, 2010), 124.

${ }^{36}$ Proceedings and Debate, 363, 364, 365.

${ }^{37}$ Proceedings and Debate, 319.
} 
destined to destroy the Commonwealth. ${ }^{38}$ Accordingly, he passionately supported the freehold and castigated proposals that failed to maintain that scheme.

Other delegates opposed to changing the freehold requirement found arguments extolling man's natural right to self-government quixotic and baseless. Abel P. Upshur, representing the Eastern Shore county of Northampton, rhetorically asked if the "savages" in the "forests of America" or who "inhabit the Asiatic islands" possessed the natural right to self-government that reformers claimed all men enjoyed. Of course not, he sneered. Such "savages" lived in a crude and chaotic environment, not the hierarchical and patriarchal world of Virginia. An individual's political representation and power derived not from natural rights but rather from the society's structure in which he lived, he maintained. ${ }^{39}$ Accordingly, only those individuals in possession of certain forms of property should be allowed to vote. Private property, particularly land, satisfied that requirement. ${ }^{40}$

Upshur was not alone in his denunciation of "natural rights." Numerous conservative and moderate delegates supported Upshur's rationale, arguing that reformers' emphasis of "natural rights" in connection to enfranchisement undermined their own argument. Philip Pendleton Barbour of Orange County, in a pointed speech directed to reformers, wondered if "individuals of the discarded classes" should also be allowed to vote considering they supposedly possessed natural rights. Women, children, laborers, the disabled, and other dependents, were among the "discarded" who lacked sound political or moral judgment. ${ }^{41}$ Some delegates sarcastically wondered if the "natural rights" argument could be extended to African Americans. Littleton Waller Tazwell, representing Norfolk, and Upshur, both asked reformers how they can "limit

\footnotetext{
${ }^{38}$ Randolph quoted in Freehling, Drift Toward Dissolution, 63.

${ }^{39}$ Proceedings and Debate, 67.

${ }^{40}$ Proceedings and Debate, 65-79.

${ }^{41}$ Proceedings and Debate, 97.
} 
themselves to white population alone." For if all men possessed the same natural rights, how could reformers exclude African Americans, Native Americans, or other "savages," they inquired. ${ }^{42}$ The inclusion of such "discarded classes" threatened to make a mockery of Virginia's slaveholding society and nullify the color line that supposedly demarcated freedom from bondage. Even the most avid reformers refused to countenance black voting. The "natural rights" argument, once thought to be a powerful weapon for reformers, now emerged as a formidable stumbling block as they pursued expanded suffrage.

The debates over reapportioning the state legislature were as equally divisive as those on suffrage, with the two issues often intermingling. As with suffrage, northwestern delegates believed their proposals reflected the correct interpretation of the American Revolution by recognizing white equality. Accordingly, northwestern and western delegates supported the "white basis" plan. Under this proposal, only the free white population would be considered when calculating representation, excluding African American slaves and taxes. Cognizant of their rapidly increasing white populations, delegates from Northwest and western Virginia generally argued that this plan would correctly recognize majoritarian power and reflect the current demographic shifts altering the state's human geography. Armed with a majority in the state legislature, western Virginians could soon realize their hopes of internal improvements to enhance communication and commercial access and a public education system to educate residents.

Proponents of the "white basis" contended that this proposal recognized the memory of the American Revolution. Only white citizens, reformers contended, deserved political representation because they constituted "the people." Opponents of the "white basis," though,

\footnotetext{
${ }^{42}$ Proceedings and Debate, 68, 331. [emphasis in original]
} 
perceived in this plan the "tyranny of the majority" that some Founding Fathers feared. ${ }^{43}$ These opponents of the "white basis" caustically referred to it as "King Numbers." John Randolph, one of the plan's more vocal opponents, stated unequivocally that he "would not live under King Numbers." He would neither allow "King Numbers" to act as his "steward" nor "task-master."44 For Randolph and his ilk, the implications of living under "King Numbers" were dire, as they would be powerless to control "King Numbers," unlike their current dependents. The carefully ordered world that Randolph reigned over would be upset.

The epithet "King Numbers" was an important rhetorical tool wielded by anti-reformers and opponents. These men wielded this moniker to deny reformers' ideological motivations, arguing that this plan sanctioned mob rule and political anarchy. Indeed, "King Numbers" succinctly and powerfully captured opponents' fears in widely accessible phraseology while simultaneously advancing their interpretation of the American Revolution. The word "king" reminded Virginians about the abusive, tyrannical, and arbitrary nature of despotic rulers. Virginians needed no clearer evidence of such behavior than their experience with King George III during the American Revolution. His capriciousness and dismissive attitude toward the colonies still burned brightly in the minds of Virginians, especially as their home represented a locus of political independence and military engagement.

Further, by connecting “King Numbers” to King George III, anti-reformers appropriated the memory of the American Revolution to reflect their interpretation and outcome of that seminal moment. The colonies revolted to free themselves from a tyrant, conservatives argued, not to inaugurate the dangerous doctrine of majoritarian rule. Why replace one tyrant with a

\footnotetext{
${ }^{43}$ John Adams, A Defence of the Constitutions of the Government of the United States of America (Philadelphia: Budd and Bartram, 1797), 3:291.

${ }^{44}$ Proceedings and Debate, 321.
} 
thousand tyrants? What Virginians needed were men trained in classical thought, not trained behind a plough, to lead them and protect the republic. The narrative of the American Revolution propagated by northwestern and western delegates represented a dangerous canard, conservatives and opponents insisted, designed to overthrow benevolent and educated rulers and replace them with the uneducated and crude masses.

This uneducated and crude mass of men represented the seemingly overwhelming and limitless power of "Numbers." Faceless and nameless, this mob of men welcomed violent confrontation, willfully flouting proper legal and political boundaries to achieve a desired end. This corrupt and uneducated mass possessed no guiding political principles but rather operated under the control of slick orators with deep pockets or libations. This majority would "oppress, harass, and plunder the minority," leaving private property and wealth vulnerable. ${ }^{45}$ The effect of "Numbers" would extend to the ballot box, too. Elections would not be won by the most deserving candidate but by the one who mobilized the required "numbers" to the polls, sullying elections and overturning traditional authority. Corrupt political manipulators would replace benevolent and selfless politicians, using their position to consolidate power rather than using it to protect the republic. "[N]o inherent virtue" could be found in such circumstances, conservatives maintained, only an abusive majority that used its "physical power" to achieve its political goals. ${ }^{46}$ Put simply, the reign of "King Numbers" would prove fatal to the body politic. Northwestern delegates understood the damage the epithet "King Numbers" inflicted and tried to soften its blow. Alexander Campbell contended that this plan of representation would "operate to the advantage of the whole state" by replacing the state's current "monarchical and aristocratical" form of government. Nonfreeholders and nonslaveholders who lived in the

\footnotetext{
45 Proceedings and Debate, 317.
}

${ }^{46}$ Proceedings and Debate, 68. 
shadows of their powerful neighbors would enjoy the political representation and equality they deserved as white men under the "white basis," as well. ${ }^{47}$ Charles Morgan maintained that "King Numbers" accurately reflected the new political and social context unfolding around them. "King Numbers" represented the "legitimate sovereign of all this country," he stated, and that “General Jackson" was the only "lawful representative of King Numbers." The glorification of the "common man" at the heart of Jacksonian Democracy appeared unstoppable with President Andrew Jackson at the helm. And while this movement was nascent, its supporters had already toppled tyrannical rulers and rewrote aristocratic constitutions elsewhere. Opponents of "King Numbers" stood against the tide of history, Morgan declared, for a more "wise, benevolent, patriotic and powerful" ruler could not be found in the United States or the world. By inaugurating "King Numbers," Virginians would embrace the dynamic that power rested in the "supreme tribunal" of the state, "public opinion." 48

Still, few, if any, conservatives, anti-reformers, or even moderates welcomed the prospect of living under "King Numbers." Opponents declared that Virginia would witness the same scenes of popular unrest and violence that beset France during the tumultuous years of the French Revolution. Benjamin Watkins Leigh cautioned the convention of "experiment[ing] on the body politic" in the same manner as France. The "large dose of French rights of man," nearly identical to the "natural rights" advocated by western reformers, inevitably led to "fever, frenzy, madness and death," he warned. ${ }^{49}$ Once again, Leigh employed a revealing metaphor to express his fears. Nineteenth-century medical procedures often proved dangerous, if not fatal, and medicine often enjoyed the same infamous notoriety from skeptical Americans who

\footnotetext{
${ }^{47}$ Proceedings and Debate, 118.

${ }^{48}$ Proceedings and Debate, 389. [emphasis in original]

${ }^{49}$ Proceedings and Debate, 151. For other references to the French Revolution, see Proceedings and Debate, 138, 150.
} 
distrusted medical quacks and the "cures" they peddled. ${ }^{50}$ France's condition worsened as democratic reformers administered more and more of their "rights of man" dosage, Leigh reminded his colleagues, and reformers continued this prescription until France's body politic violently convulsed and died. The implications for the Old Dominion were clear. Unless delegates rebuked reformers and their quack medicine, Virginia awaited the same fate as the French Republic.

Imagery and rhetoric derived from the French Revolution became so ubiquitous among anti-reformers that it provoked an outburst from Philip Doddridge. "We should imagine that we are listening to [Edmund] Burke on the French Revolution," he remarked. "All the horrors of that volcano are set before us," he protested, "as if in our madness, we were ready to plunge into it."51 But the frequent references to the French Revolution — and Doddridge's outburst— illustrated the power of that moment's historical memory to inform delegates' interpretation about constitutional revision in Virginia. To opponents of reform, the French Revolution represented the dangers of democracy. That moment encapsulated opponents' fears of an enlarged (and largely landless) electorate, the reign of "King Numbers," and the vulnerability of private property. The fears appeared tangible enough for opponents and numerous moderates to oppose "King Numbers" and support another form of representation that took into consideration the white population and private property. Delegates referred to this plan as the "mixed basis." 52

Apportionment in the state legislature based on the "mixed basis" reflected supporters" fears of private property in a democratic society. Private property deserved extra security, supporters argued, both because of its inherent vulnerability and taxable nature. Perhaps no

\footnotetext{
${ }^{50}$ Michael Sappol, A Traffic of Dead Bodies: Anatomy and Embodied Social Identity in Nineteenth-Century America (Princeton: Princeton University Press, 2002).

${ }^{51}$ Proceedings and Debate, 425.

${ }^{52}$ Bruce, Rhetoric of Conservatism, 63-64.
} 
species of private property appeared more vulnerable than African American slaves. During the convention, approximately eighty-two percent of the state's political elite owned at least one slave; nearly one-third were planters. ${ }^{53}$ By 1830 , Virginia was home to more slaves than any other state in the Union, nearly 470,000 slaves. ${ }^{54}$ Though the majority of slaves lived east of the Blue Ridge Mountains, every county in the state, including the Northwest, held slaves. Ohio County had 360 slaves, while residents in Brooke County, the northernmost extension of the state, owned 228 slaves. ${ }^{55}$ While delegates considered slavery solely an issue for eastern Virginians, the ubiquitous presence of enslaved African Americans across the state produced constitutional debates over slavery and slaves' political weight that were critical to all Virginians.

Tidewater and Piedmont delegates, representing districts with larger numbers and a higher density of enslaved African Americans, contended that their constituents required greater political and constitutional protection. This need for extra security was urgent, too. The recent violent overthrow of Santo Domingo's slaveholding regime, coupled with the memory of Gabriel Prosser's failed rebellion in 1800 (and Denmark Vessey's in South Carolina in 1822), convinced many Virginians (and numerous white southerners) that egalitarian rhetoric and ideals were too dangerous in a slave society. ${ }^{56}$ Philip Pendleton Barbour justified his reticence for embracing democratic principles by connecting this system of government to "the frightful and appalling scenes of horror and desolation" that marked the downfall of Santo Domingo's slaveholders. ${ }^{57}$ Benjamin Watkins Leigh candidly confessed that slaveholders "cannot admit any interference"

\footnotetext{
${ }^{53}$ See Table 5.4 "Slaveholding of the political elite, 1788-1861," and Table 5.5 "Slaveholding status of members of the House of Delegates, 1788-1860," in Shade, Democratizing the Old Dominion, 176-177.

54 "Total Slave Population," UVA Census Browser [http://mapserver.lib.virginia.edu/php/state.php] [accessed 9 January 2015]

${ }^{55}$ Freehling, Drift Toward Dissolution, 27-28.

${ }^{56}$ Wilentz, Rise of American Democracy, 87-89 and White, Encountering Revolution.

${ }^{57}$ Proceedings and Debate, 91.
} 
with their property "without the greatest danger." ${ }^{58}$ Conservative delegates believed that any outside interference with their chattel imperiled the master-slave relationship and their sacrosanct right to private property. In a democratic society, such fears were heightened by white residents openly discussing equality and natural rights, words that slaves might hear, internalize, and act upon. Nonslaveholders, conservative delegates reasoned, especially those living in an area with few slaves, failed to appreciate such fears. Extra constitutional and political protection for slaveholders, though, would help calm slaveholders' fears and ensure that Virginia's slaveholding regime prevented any uprising.

Conservatives' skepticism concerning democratic reforms in a slaveholding state also reflected their doubt that African American bondage could flourish in the Northwest. Various reasons existed for such reasoning, Abel Parker Upshur explained. "[A] rooted antipathy to this species of population" existed beyond the Alleghenies, he stated, intimating that a crude form of antislaveryism could be found in western Virginia's hollows and hills. Upshur also wavered on whether slavery could exist so close to free states. The region's proximity to Ohio and Pennsylvania would "forever render this sort of property precarious and insecure," he warned, and remarked that the Ohio River or an abstract state boundary was inadequate for stemming northerners' increasing hostility against slavery. The region's climate prohibited widespread plantation agriculture, notably cotton and tobacco, making the need for slave labor unnecessary. Rather, northwesterners relied on "personal industry" and "personal exertion," not slave labor, to improve their homes and farms. For the foreseeable future, Upshur maintained, slaveholders would constitute a minority and slavery would never flourish on the windward side of the Alleghenies. ${ }^{59}$

\footnotetext{
${ }^{58}$ Proceedings and Debate, 172.
}

${ }^{59}$ Proceedings and Debate, 76. 
Upshur's claims about the Northwest reveal his and other conservatives' ignorance of the region and static view of slavery. Slavery existed in every county in Virginia, including those in the Northwest, such as Brooke, Ohio, and Monongalia. The first two counties bordered Ohio and Pennsylvania while Monongalia shared a border with the Keystone State. Conservatives, accustomed to living in a slaveholding society where slaves comprised the dominant labor force, overlooked how slave labor constituted one form of labor available in northwestern counties. ${ }^{60}$ Though slave labor was not the dominant labor force in the region, northwestern slaveholders exploited this type of labor like other slaveholders across the state. One local historian stated that slaves were "employed in domestic service, driving teams and ordinary labor."61 Slaveholders across the Northwest and Appalachia used their slaves to tend sheep, prepare wool for market, export livestock down the Ohio River and to New Orleans, and rear cattle and pigs for slaughter and transport to Baltimore. While not engaged in traditional slave labor agriculture, northwestern slaves demonstrated the dynamism and adaptability of slavery to a new and different physical landscape and political-economy.

Other practices concerned with slavery would have reminded easterners of their society. Northwesterners meted out corporal punishment against rebellious or unrepentant slaves, including by whipping and burning. ${ }^{62}$ Northwestern slaveholders, similar to other slaveholders across the state and South, sought to protect their slaveholding rights by including local whites in various functions. Some slaveholders hired local poor whites to oversee their slaves on seasonal cattle drives, allowing these men to exert mastery over African American slaves and enjoy the fruits of white supremacy. Slaveholders also rented pastures from nonslaveholders for their

\footnotetext{
${ }^{60}$ Ira Berlin, Many Thousands Gone: The First Two Centuries of Slavery in North America (Cambridge: Belknap Press of Harvard University Press, 1998).

${ }^{61}$ Haymond, History of Harrison County, 302.

${ }^{62}$ Maxwell, History of Monongalia County, 232-235.
} 
animals to graze. ${ }^{63}$ These actions helped slaveholders further their investment in slaves while promoting amicable (and often profitable) relations with their nonslaveholding neighbors. The bond established between slaveholders and nonslaveholders also sought to promote a shared interest in the future and security of slavery, a critical relationship if and when slavery seemed threatened. Renting slaves, though it occurred less frequently in the Northwest than near southwestern Virginia's Kanawha salt mines, allowed northwestern slaveholders to extract more money from their chattel while encouraging nonslaveholders to support slavery and the slaveholding regime. Renting slaves also promoted harmonious relations between slaveholders and nonslaveholders, with the latter group able to take advantage of an extra set of hands for domestic duties or harvest time. ${ }^{64}$ Though the majority of northwestern residents maintained their farms through family labor and "personal industry," slave labor was also readily available.

With their fealty to slavery questioned, northwestern delegates attempted to persuade skeptical delegates about the benefits of a democratized slaveholding polity and the compatibility of slavery and democracy. Eugenius Wilson posited that a democratized constitution would forever bind the interests of the slaveholder and nonslaveholder. Inferring that the Missouri Compromise and the Nullification Crisis were harbingers of future conflicts over slavery, Wilson pleaded with delegates to "unite" all "free white" men in preparation of an inevitable "crisis." With the slaveholder and nonslaveholder possessing identical political interests, Virginians would stand united against any threat to slavery. ${ }^{65}$ Philip Doddridge believed that the latest census data showing an increase in the slave population in the Northwest demonstrated that

\footnotetext{
${ }^{63}$ Wilma A. Dunaway. "Slavery and Emancipation in the Mountain South: Sources, Evidence and Methods," Virginia Tech, Online Archives, Table 3.1. [http://scholar.lib.vt.edu/faculty_archives/slavery/livestoc.htm] [accessed 13 January 2015]

${ }^{64}$ John J. Zaborney, Slaves for Hire: Renting Enslaved Laborers in Antebellum Virginia (Baton Rouge: Louisiana State University Press, 2012). For examples of slaves available for rent in the Northwest, see Clarksburg Intelligencer, February 5, 1825, 1 and Clarksburg Intelligencer, May 21, 1825, 4.

${ }^{65}$ Proceedings and Debate, 382.
} 
slavery and democratic supporters could peacefully coexist. ${ }^{66}$ Skeptical delegates needed to look no further for evidence of such a claim than Doddridge, a slaveholder and passionate exponent of democracy. ${ }^{67}$ Richmond banker Chapman Johnson broke ranks with his eastern colleagues and supported these assertions by northwestern delegates. Johnson declared that fixing legislative apportionment on the "white basis" would foster "a feeling of affection and sentiment of justice" between western nonslaveholders and eastern slaveholders and ultimately protect slavery. ${ }^{68}$ Near the convention's conclusion, Alexander Campbell attempted to introduce an antislavery petition only to be dissuaded by colleagues. While Campbell's motives remain murky, his colleagues feared that this petition would only stoke sectional tensions, incorrectly brand all westerners as antislavery, and validate opponents' arguments about westerners' unsound position on slavery. ${ }^{69}$ Northwestern delegates remained publicly mum on Campbell's conduct. Rather, they continued to proclaim that they sought only to protect slavery while prohibiting eastern slaveholders exercise of "political dominion" over northwestern residents. Democratic reform promised to secure both. ${ }^{70}$

In the Northwest, the convention played out in newspapers, keeping residents abreast of debates, suffrage and apportionment proposals, the conduct of their elected representatives, and overall pursuit of democratic reform. As the convention commenced, residents expressed optimism that their representatives' arguments and evidence would convince other delegates to embrace reforms. The obduracy displayed by "tide-water men," though, incited anger and

\footnotetext{
${ }^{66}$ Proceedings and Debate, 448.

${ }^{67} 1830$ U.S. Federal Census: Brooke, Virginia; Series: M19; Roll: 189; Page: 143; Family History Library Film: 0029668 [Ancestry.com] [accessed 16 January 2015].

${ }^{68}$ Proceedings and Debate, 282.

${ }^{69}$ Hizer, "Virginia is now Divided," 308. Campbell's petition likely reflected a mixture of frustration and personal and religious sentiment. As a devoted evangelist and democratic reformer, Campbell likely interpreted his and his colleagues' failure because of the overwhelming interest in slavery.

${ }^{70}$ Proceedings and Debate, 88.
} 
dismay in many residents. Such men, residents decried, "are not inclined to trust the people at large with any powers." ${ }^{71}$ In Wheeling, the local newspaper editor excoriated conservative delegates who wondered about the efficacy of a constitutional statute that would prohibit new residents to the state from voting for five years. This political quarantine imposed upon new residents threatened to undercut western Virginia's growing white population, especially that around Wheeling, where industrial jobs attracted prospective employees. Immigrants from Delaware, Pennsylvania, and New Jersey accelerated the region's demographic growth, as the population rose approximately forty percent between 1820 and $1829 .{ }^{72}$ Wheeling, above other towns in Virginia, the editor maintained, depended on this influx of immigrants from other states for their "capital, industry, and enterprize." The five year quarantine amounted to an attack on Wheeling and its growing industrial sector, and further sowed seeds of competition and distrust between residents of Wheeling and eastern Virginia. The newspaper editor nonetheless expressed his optimism that this "obnoxious and preposterous proposition" would meet its due fate. $^{73}$

Perhaps more galling for northwestern residents than the rumored five year political quarantine was the rhetoric and logic of Benjamin Watkins Leigh. Leigh, foreshadowing James Henry Hammond's “mud-sill” speech, equated the tasks that slaves performed in eastern Virginia with those performed by poor yeomen and landless peasants in western Virginia. But while the latter group would receive political representation under reformers' plans, slaves remained excluded (and rightfully so, according to Leigh, for they lacked proper morality and intellect). Still, Leigh questioned whether "those who are obliged to depend on their daily labour

\footnotetext{
${ }^{71}$ Wheeling Compiler, October 28, 1829, 3.

72 Wilentz, Rise of American Democracy, 341.

${ }^{73}$ Wheeling Compiler, November 11, 1829, 3.
} 
for daily subsistence" should be engaged in "political affairs." According to Leigh, the answer was simply "no." The "peasantry of the west," he confirmed, were ill-prepared and uneducated for the rigors of republican citizenship. These men lacked the political fitness to participate in politics, and their inclusion would inherently threaten all Virginians and private property. The security of the state depended on the continued exclusion of these "peasants."

Not surprisingly, Leigh's comparison of enslaved African Americans and western whites went over poorly with western residents. His words were met with a mixture of apoplexy and disbelief, as northwestern white residents considered their equation with slaves as anathema. Such a comparison represented one of the basest and degrading insults a white southerner could receive as it appeared to flout the color line that supposedly demarcated white from black, freedom from bondage. Now Leigh, and possibly other members of his ilk, seemed comfortable in imposing the same shackles on white residents as their slaves. Residents assailed such possibilities. Those white men who toiled behind the "plough" or worked with "mechanic's tools" sharpened their moral and physical skills, they argued, which prepared them for the rigors of republican citizenship. These white men controlled their labor and deserved the political representation to protect that labor. "[T]ide-water gentlemen" such as Leigh, though, enjoyed "amusements and vices" while they lived off the "labour of their slaves." 75 Indolent planterpoliticians like Leigh contributed little to the Commonwealth and failed to recognize that political representation for the "peasantry of the west" would ensure security for private property and a healthy body politic. Rather, Leigh and his colleagues preferred to rest on the security of antiquated political reasoning, favoring paranoia to practicality.

\footnotetext{
${ }^{74}$ Proceedings and Debate, 158-159.

${ }^{75}$ Wheeling Compiler, November 18, 1829, 3.
} 
Leigh's figurative equation of African American slaves to white westerners coupled with news of the convention's rejection of reforms worried northwestern residents. And, by the end of 1829 , their delegates shared that sense of disappointment and frustration. Efforts to directly elect the governor failed, even though most delegates agreed that the governor should remain politically weak. The prospect of the people electing the executive still seemed too dangerous for many delegates to accept. ${ }^{76}$ Alexander Campbell introduced a measure to promote common schools; the convention refused to debate its merits. ${ }^{77}$ Supreme Court Chief Justice John Marshall countered accusations that the county court system encouraged nepotism and corruption, maintaining that the current system enabled judges to mete out punishment judiciously and independently without fear of rebuttal from an oversight body. The system also ensured an unrivaled form of "internal quiet" that other states, especially those in the North, envied. ${ }^{78}$ Northwestern delegates hoped that the two former presidents' support for reform would sway moderates and undecided; instead, Monroe only warmly supported some measures while Madison consistently voted with opponents of reform. ${ }^{79}$

Opponents of democratic reform measures enjoyed numerous victories, including representation in the state legislature. A modest change to the formula calculating representation still allotted the majority of delegates to Piedmont and Tidewater counties, forty-two and thirtysix respectively. Voters in the twenty-six counties west of the Alleghanies, where the majority of the white population resided, received thirty-one delegates. The convention applied the same arbitrary scheme of apportionment to the Senate. The forty counties west of the Blue Ridge Mountains received thirteen senators while the sixty five counties on the eastern side of the Blue

\footnotetext{
76 Tarter, Grandees of Government, 187 and Bruce, Rhetoric of Conservatism, 66-67.

${ }^{77}$ Proceedings and Debate, 750, 786-787.

78 Proceedings and Debate, 505 and Tarter, Grandees of Government, 187.

${ }^{79}$ Proceedings and Debate, 150, 537-539, 573-574.
} 
Ridge received nineteen. This favorable allocation of representation to eastern districts represented a measure of "double security" for eastern slaveholders who paid taxes on their slaves and on products purchased from the profits of slave labor. ${ }^{80}$ Northwestern delegates and residents hopeful that a future amendment could change the formula used to calculate representation were dismayed that the new constitution forbid the General Assembly to alter the number of delegates or senators allotted to each district. ${ }^{81}$ What one Wheeling newspaper labeled as "THE BASIS OF ABSURDITIES" further cemented the preponderance of political power wielded by planters, slaveholders, large landholders, and the political elite. ${ }^{82}$

Reformers' hopes for expanding suffrage met the same fate as their aspirations for altering representation in the state legislature. Northwestern delegates championed plans that either would have inaugurated universal male suffrage or a form of general suffrage fell victim to conservatives and moderates who feared the repercussions of democratic reform. Instead, delegates ratified a proposal that appeared only to modestly increase those eligible to vote. Among those now permitted to vote included those enfranchised under the previous constitution; owners of a freehold worth at least twenty-five dollars; leaseholders whose annual rent was at least twenty dollars and who had held that lease for a minimum of five years; anyone who legally stood to inherit a freehold; housekeepers in charge of maintaining a residence; tenants and jointtenants; and those who possessed land as part of a corporation, held a title in equity, and who held a mortgage. ${ }^{83}$ The addition of these new groups to the electorate signaled a marked

\footnotetext{
${ }^{80}$ Proceedings and Debate, 75.

${ }^{81}$ Tarter, Grandees of Government, 186-187. Many delegates at the convention believed that the control of the House of Delegates was especially critical, as its members held the sole responsibility for introducing legislation. With the majority of delegates in the lower house, eastern delegates could (and did) easily defeat northwestern and western proposals for more internal improvements and a public school system.

${ }^{82}$ Wheeling Compiler, December 9, 1829, 3.

${ }^{83}$ Curtis, Jefferson's Freeholders, 114-119.
} 
departure from the values of economic and political independence and civic virtue that defined republican citizenship, although it still fell short of reformers' goal of universal suffrage.

The denial of universal male suffrage or a form of general suffrage incensed northwestern residents, and historians have seized on this frustration to argue that delegates ratified a facsimile of the previous constitution that included only modest alterations. ${ }^{84}$ But the changes made to suffrage revealed important developments occurring in Virginia, and signaled delegates' acknowledgement of a new economic context. Though officeholders still had to own a freehold, the increased electorate meant increased power for voters to check politicians' conduct. While previous definitions of the freehold focused on its acreage, delegates at the convention, cognizant of market forces, redefined the freehold in terms of its commercial value. This redefinition recognized land's economic qualities and its status as a transferrable commodity. Freeholds could be divided and transferred without undermining the principal ownership, allowing men to purchase parcels of a freehold as a stock or bond and vote without outright owning the freehold. This change reflected a critical shift from classical republican ideology that had informed the initial interpretation of a freehold. Perhaps more importantly, this redefinition and reconceptualization of republican ideology presented the scenario of slaveownership constituting a basis for republican citizenship in the future. ${ }^{85}$

The enfranchisement of tenants, leaseholders, and housekeepers likewise signaled an acknowledgement of current economic forces and an important ideological transformation of republicanism. Charles Fenton Mercer, the measure's principal author, believed that land represented only one form of capital and that sundry other forms attached Virginians to their

\footnotetext{
${ }^{84}$ Freehling, Drift toward Dissolution, Freehling, Secessionists at Bay, Shade, Democratizing the Old Dominion, Bruce, Rhetoric of Conservatism, and Wilentz, Rise of American Democracy.

${ }^{85}$ Curtis, Jefferson's Freeholders, 116-117, 121-125.
} 
state. Those men in possession of other forms of "other property besides land," he suggested, showed their fealty and support to Virginia similar to a "land-owner." Further, Mercer and other supporters of this proposal recognized that both land and labor generated important capital, and that the "proprietors" of this capital deserved political representation to protect their interests. ${ }^{86}$ Mercer's suffrage proposal "bridged the antagonistic arguments of democratic and conservative delegates," although some conservatives, including Benjamin Watkins Leigh, feared that this redefinition of citizenship would affect universal male suffrage. ${ }^{87}$ While the proposal did not inaugurate universal male suffrage, the reconceptualization of property as principally a form of capital represented a critical ideological shift away from classical republican ideology and to a more democratized government.

Western and northwestern Virginians applauded many of these reforms and signaled their desire to ratify the new constitution. In Martinsburg, one newspaper editor considered the constitution's ratification the "desired policy of the West." The new constitution "contains many beneficial reforms, and, secondly, because it encreases its relative political weight and enables it at some future day to assert more effectually, the proper basis of representation." The constitutional revolution demanded by westerners "must be gradual," the editor conceded. ${ }^{88}$ Philip Doddridge "admit[ted] the superiority of the new [constitution] over the old one," a phrase some western Virginians interpreted as his tacit approval. ${ }^{89}$ A Shenandoah Valley newspaper identified northwestern newspapers that supported ratification, including one in Wheeling, Clarksburg, and Morgantown. The newspaper also noted that Monongalia delegate Charles Morgan endorsed the new constitution, "declar[ing] his determination to vote for the new

\footnotetext{
${ }^{86}$ Proceedings and Debate, 442.

${ }^{87}$ Curtis, "Reconsidering Suffrage Reform," 118-120 and Proceedings and Debate, 639.

${ }^{88}$ Martinsburg Gazette \& Public Advertiser, February 18, 1830, 2.

${ }^{89}$ Virginia Free Press (Charles Town), April 21, 1830, 3.
} 
Constitution, and urg[ing] such arguments in favor of the expediency of its ratification." Morgan, "an ardent friend of reform," would persuade his constituents to ratify the new constitution as his words carried "great weight" in the region. ${ }^{90}$

Western and northwestern Virginia's denunciations, however, drowned out such favorable interpretations of the proposed constitution. Numerous transmontane residents lashed out in frustration and anger because delegates failed to fully democratize the state constitution, notably in refusing to inaugurate universal male suffrage and equal representation. By early 1830, two northwestern delegates emerged as outspoken critics. Philip Doddridge and Alexander Campbell assailed James Monroe, James Madison, and Frederick County delegate John Cooke, the lone western representative to support ratification, for their apostasy to the democratic cause. Doddridge lamented the divisions that arose between western delegates on matters of reforms, which hindered their ability to form a united front and parry attacks from moderates and conservatives. Perhaps most concerning for Doddridge was what he interpreted as residents' capitulation toward the new constitution's ratification. This posture of "submission," he declared, represented what eastern slaveholders desired to see in their chattel. Northwestern whites appeared consigned to live under a "political compact" that promised "slavery of us and our children," turning a once bright political future for the region into one dominated by eastern planter-politicians consumed with their pursuit of absolute power and absolute protection for their chattel. ${ }^{91}$

Alexander Campbell's interpretation of the convention's denouement and future prospects for the Northwest seemed equally foreboding. In a series of letters printed in the Wellsburg Gazette, Campbell denounced the machinations of a manipulative "faction" that

\footnotetext{
${ }^{90}$ Virginia Free Press, April 7, 1830, 3.

${ }^{91}$ Virginia Free Press, March 31, 1830, 1-2.
} 
flouted the will of the majority. ${ }^{92}$ The minister found conservatives' and anti-reformers' characterizations of western reformers abhorrent, along with their fear mongering tactics. Such delegates, Campbell declared, willfully spread rumors about westerners imposing draconian taxes upon the ratification of a democratic constitution. The fear generated by this canard resulted in countless "[p]etitions, remonstrances and expostulations, inflammatory speeches and addresses" produced by eastern Virginians who immediately became "alarmed for their negroes and their estates."93 This canard produced the desired effect, Campbell lamented, as moderate and conservative delegates expressed their constituents' fears through the rejection of democratic reforms.

Campbell found little to support in the new constitution. What good was the extension of suffrage, he questioned, "when it can be of no use to use except annually to meet, [and] to murmur at our masters." While their "masters" denied northwesterners political representation, they would willfully impose taxes to support a "standing army...to keep down the slaves" or impress them to quell an "insurrection." White northwesterners would be compelled to support the institution that denied them political equality. "[W]e must be demislaves, or an Irish peasantry, or a species of heliots," Campbell decried, serving at the whims of the state's slaveholding regime. African American slavery, that "curse of curses, which has deluged every country with crime, and engulphed it in ruin," now prevented white northwesterners from enjoying the political privileges that rightly belonged to them. Until Virginians had a frank discussion about that "black cloud in our horizon," northwestern residents would continue to find themselves under the dominion of slaveholders. ${ }^{94}$

\footnotetext{
${ }^{92}$ Wellsburg Gazette, reprinted in Wheeling Gazette, February 27, 1830, 2.

${ }^{93}$ Wellsburg Gazette, reprinted in Wheeling Gazette, March 6, 1830, 2.

${ }^{94}$ Wellsburg Gazette, reprinted in Wheeling Gazette, April 3, 1830, 2.
} 
Northwestern residents, like their representatives, found little in the proposed constitution to applaud. Earlier drafts of various proposals that delegates transmitted to constituents in late 1829 stirred emotions among proponents desirous of universal male suffrage specifically and democratic reform in general. Rather than expunging the "antiquated and anti-republican principles" that shaped the state's political institutions and culture, the convention has been busily "fastening the yoke of the slaveholder's supremacy upon the necks of the white population." Reforms championed by residents had all seemingly failed, with the blame resting at the feet of planter-politicians, large landowners, and the political elite. "Honest labour" and "[i]ntelligence and industry" disqualified northwestern white men from enjoying political representation, as such virtues apparently meant little in Virginia. Rather, the status of a landholder "gives a better title to the enjoyment of civil rights." 95

By early 1830, northwestern residents, in possession of the proposed constitution, argued that the constitution represented a reaffirmation of divisive and dangerous sectionalism. "[E]astern Virginia will never conform to the interests or views of Western Va.," one anonymous writer grumbled, arguing that the two possessed incompatible and antagonistic interests. To remedy this, western Virginia should explore annexation to Maryland. The "greater intercourse" between western Virginia and Maryland would politically revitalize the region and promote commercial interests. ${ }^{96}$ Another writer compared Virginia to neighboring Ohio and remarked at the "Egyptian darkness" that enveloped the "Antient Dominion." The new constitution ensured this "Egyptian darkness" while the document's prohibition on alteration ensured that Virginia's planter-politicians would continue to wield power over their "white slaves, as well as black." A

\footnotetext{
${ }^{95}$ Wheeling Compiler, December 2, 1829, 3.

${ }^{96}$ Wheeling Gazette, November 6, 1830, 3.
} 
division of the state along the Alleghenies presented the only means of achieving political representation for white northwesterners while freeing themselves from political bondage. ${ }^{97}$

Many northwestern residents spoke frankly about slavery's role in denying their pursuit of democratic reform. One resident was incredulous that a "race of beings, having no political exestinence, and who are moreover deprived of their every natural right" seemingly enjoyed political representation while countless northwesterners remained locked out. Planter-politicians "white-washed" their slaves so it would appear these men still abided by the color line that separated freedom from bondage. Instead, in their pursuit of power and security, these slaveholders' made a mockery of the color line. ${ }^{98}$ An anonymous writer, "JUSTICE," recounted the "memorials," "writings," and "conventions" over the past thirty-five years undertaken by residents who, once hopeful for a democratic constitution, now discovered themselves in "political bondage." The author saved his most caustic remarks for the proposed constitution's arbitrary means of allocating representation. He warned his audience of the dangers of "amalgamating...the free white and slave population," believing that the two races should remain separate.

The author's verb selection was revealing. In nineteenth-century lexicon, "amalgamate" generally referenced the interracial sexual contact between white men and enslaved female African Americans. Eastern Virginia's long history of slavery and large number of slaves increased the likelihood of such contact, but slaveowners refused to acknowledge this tawdry history. The appearance of mulatto children on the plantation and at auctions, though, seemed to validate such rumors. A "large percentage of human stock shipped to the Gulf States," one contemporary later remarked, "bore the best blood of the F.F.V." as a result of this "cross-

\footnotetext{
${ }^{97}$ Wheeling Gazette, March 27, 1830, 3.

${ }^{98}$ Wheeling Compiler, December 30, 1829, 3.
} 
breeding." 999 The author's use of "amalgamate" recognized not only the long history of interracial sexual contact between whites and blacks but the verb also served as an underhanded swipe at eastern slaveholders. While such men spoke of the need to protect private property and minority rights, these pronouncements were timeworn bromides designed to obscure their true intentions. Eastern slaveholders prized their chattel over their white neighbors and the proposed constitution manifested that sentiment. ${ }^{100}$

Prior to the vote on the proposed constitution, residents convened across the region to discuss the constitution and its implications. Residents gathered at the Wheeling courthouse in December 1829 to voice their displeasure with conservatives' and moderates' refusal to embrace democratic reform. The gathered men expressed outrage concerning the convention's rejection of the "white basis," and strongly denied that the "free laborers of the West" shared the same degraded status as "the slaves of the East, or the peasantry of Europe." Their labor, morality, and intellect separated them from such degenerates. ${ }^{101}$ In nearby Randolph County, residents declared the proposed constitution to be "distructive of the natural rights of man" and perceived in the document the same principles that the "British Crown" foisted upon their forefathers. While much of the nation and slaveholding South enjoyed a "free elective democracy," the new constitution seemed prepared to throw northwesterners "into the dark and gloomy abyss of aristocracy." 102

In March 1830, a few weeks prior to the official popular vote on the proposed constitution, a spontaneous gathering of residents met at the home of Samuel Woods, a

\footnotetext{
${ }^{99}$ Hall, Rending of Virginia, 49.

${ }^{100}$ Wheeling Gazette, March 13, 1830, 3.

${ }^{101}$ Wheeling Compiler, December 23, 1829, 3.

102 Clarksburg Enquirer, March 20, 1830, 2.
} 
prominent lawyer and slaveholder. ${ }^{103}$ Woods, called to chair the meeting by those gathered, oversaw the passage of four resolutions that emphasized residents' belief that 'the new constitution, both in letter and spirit, opposed" the "principles" found in the Bill of Rights. Residents concluded that they would oppose the constitution "by our votes" or, for those disenfranchised, through "all fair and honorable means." 104 In one final plea before the popular vote, a Monongalia resident urged all of his neighbors, freeholder and nonfreeholder alike, to convene during the next court day to "adopt some measure in opposition to the ratification" of this "most ARISTOCRATICAL charter." Perhaps a united front comprised of men from all classes would illustrate the animus against the new constitution and persuade eastern politicians to discard that document and start anew. ${ }^{105}$

Prayers for a new convention or constitution went unanswered. Delegates' approval of the proposed constitution by a 55 to 41 margin in January presaged the popular vote in April. By a comfortable ten-thousand vote margin, Virginians overwhelmingly ratified the new constitution, with the majority of the support for the constitution coming from counties east of the Alleghenies. ${ }^{106}$ In the Northwest, final poll numbers revealed residents' profound opposition to the constitution. In Ohio County, residents rejected the constitution, 643-3. In Philip Doddridge's Brooke County, residents polled unanimously against the constitution. ${ }^{107}$ Further south in Harrison County, over one-thousand voters opposed its ratification while less than ten braved the hostile crowds to support the proposed constitution. Supporters of the new constitution, though, found solace in returns from Monongalia and Preston counties. Though a

\footnotetext{
1031830 U.S. Federal Census: Ohio, Virginia; Series: M19; Roll: 198; Page: 253; Family History Library Film: 0029677 [Ancestry.com][accessed 28 January 2015].

${ }^{104}$ Wheeling Gazette, March 20, 1830, 3.

105 The Republican Monongalia \& Preston Advertiser, March 16, 1830, 3.

106 Bruce, Rhetoric of Conservatism, 67-68.

${ }^{107}$ Bruce, Rhetoric of Conservatism, 68 and Proceedings and Debates, 903.
} 
majority of residents rejected the proposed constitution, over seven-hundred voted for its ratification. This figure represented one of the highest totals in the region. ${ }^{108}$

The high levels of support for the new constitution in Monongalia and Preston counties seemed out of character for the supposedly monolithic Northwest. Delegates and constituents appeared united in their pursuit of democratic reform in the decades leading up the convention, but the returns reveal a divided populace and warm support for the constitution. Evidence suggests little correlation between the percentage of slaves relative to total population and voters' support or rejection of the constitution. ${ }^{109}$ Both Monongalia and Preston had higher-thanaverage slave populations for the region but Harrison was home to more slaves than those two counties combined and voters there overwhelmingly rejected the new constitution. ${ }^{110}$ Supporters of the new constitution in these two counties may have believed that the changes to suffrage laws would eventually prove beneficial. This interpretation may have emerged from their representative, Charles S. Morgan of Monongalia, who threw his weight behind the constitution's ratification. During the convention, Morgan at times appeared apathetic, even garnering the censure of his constituents for his "anti-republican course" on certain democratic reforms. ${ }^{111}$ Unlike the outspoken proponents of democratic reform in Alexander Campbell and Philip Doddridge, who mobilized opposition to the constitution, Morgan "harangue[d]" voters as they arrived at the polls in Morgantown, exhorting them to support the new constitution. His

\footnotetext{
${ }^{108}$ Proceedings and Debates, 903.

${ }^{109}$ According to the 1830 U.S. Census, Monongalia County had 362 slaves and Preston County had 129 slaves. The percentage of slaves relative to the county's total population equaled approximately $2.5 \%$ in both counties. Those percentages are similar to those in Harrison, Ohio, and Brooke counties. "Total Slave Population, 1830" UVA Census Browser [http://mapserver.lib.virginia.edu/php/state.php] [accessed 28 January 2015] ${ }^{110}$ Harrison County had 771 slaves, the most by far in western Virginia outside of Kanawha County. "Total Slave Population, 1830" UVA Census Browser [http://mapserver.lib.virginia.edu/php/state.php] [accessed 28 January 2015] A strong religious influence in Harrison County, particularly that around Salem and Shinnston, cast doubt on religious, and by extension, political authority, resulting in a strong grassroots movement to embrace democratic ideals. Hall, Rending of Virginia, XIV-XV.

${ }^{111}$ Wheeling Gazette, October 31, 1829, 3.
} 
"mighty influence" was evident in the final tally. ${ }^{112}$ This personal style of politicking perhaps best explains the vote totals in the two counties while showing the uneven advance of democratic reform across the slaveholding South and nation. Further, the vote revealed that the divisions present during the convention carried through ratification, underscoring the Northwest's political diversity and shifting coalitions. ${ }^{113}$

Historians have generally neglected interpreting residents' support for the new constitution, focusing instead on the widespread resistance manifest in the region. Few outspoken supporters left an historical record, making it challenging to analyze their arguments. Dissenting voices likely found it difficult, if not impossible, to speak freely without garnering threats from opponents. And while some supporters of the new constitution voted to ratify it, a high probability remains that not all advocates exercised this right. Virginia's viva voce method of voting opened voters to discrimination, ostracism, and violence, especially those with different interests than those of the majority. (Free Soilers and Republicans in the region would face this same harassment in the 1850s and 1860s). Supporters who journeyed to the polls likely encountered mobs of discontented men determined to prevent votes being cast in favor of the new constitution. Faced with this dilemma, men could bow to peer pressure and vote against the constitution, turn around, or face public censure (or worse) for their opposition vote. The "interested and overbearing majority" that eastern planter-politicians feared in the guise of "King Numbers" operated on both ends of the political spectrum, advocating democratic reform while

\footnotetext{
112 Wheeling Compiler, reprinted in Kanawha Register, May 21, 1830, 2.

${ }^{113}$ The final vote totals also reveal why efforts to annex the Northwest to Ohio, Pennsylvania, or Maryland failed. The visible lack of political and sectional harmony, grinding poverty, a burgeoning two-party system that operated statewide, and identification with one's state all prevented a consensus from emerging in support of annexation.
} 
squelching opposition. ${ }^{114}$ This dynamic would become increasingly important and visible as the politics of slavery occupied state and national politics in subsequent years.

Speaking forty-five years after the conclusion of the 1829-1830 Constitutional Convention, Waitman T. Willey presented a brief biographical treatment of Philip Doddridge at the West Virginia Historical Society's meeting at West Virginia University in Morgantown. Willey, a veteran politician who had himself challenged eastern Virginians' hegemony in the 1850-1851 Virginia Constitutional Convention and had helped guide West Virginia's statehood movement during the Civil War, reduced the debates of the early convention to one issue, slavery. All the theories of government espoused by conservatives like Leigh, Upshur, and Randolph represented a guise for "the protection of slavery," he proclaimed. These leaders apprehended that increased democratization of the state and inclusion of nonslaveholders would inexorably result in oppressive taxation of chattel and perhaps slavery's "total abolition." Doddridge had battle against this powerful ideology, and though he lost, his arguments resonated with West Virginia's founding fathers during the Civil War. ${ }^{115}$

Willey's interpretation of the 1829-1830 Constitutional Convention suggests that the convention represented a conservative counterrevolution, one designed to entrench slaveholding interests and reject democratic reforms. Demagogues such as Leigh and his ilk believed that slavery and democracy represented two antagonistic elements. Doddridge battled this ideology during the convention, only to be overwhelmed by the state's slaveholding regime. This regime, consumed with its pursuit of absolute power and absolute protection for its chattel, would

\footnotetext{
${ }^{114}$ Alexander Hamilton, John Jay, and James Madison, The Federalist Papers, ed. Clinton Rossiter (New York: Signet Classic, 2003), 72.

${ }^{115}$ Waitman T. Willey, A Sketch of the Life of Philip Doddridge (Morgantown: Morgan \& Hoffman, Printers, 1875), 46.
} 
eventually lead the state to civil war and place in motion western Virginia's statehood movement.

What Willey misinterpreted about the convention, though, was that it constituted a critical moment on Virginia's path toward a slaveholding democracy. While delegates at the convention embodied and expressed conservative values and ideologies, the new constitution represented a marked departure from classical republican ideology. Virginians, who had extolled the freehold's virtues of independence and permanence, now spoke of the freehold in terms of the cash nexus. This reconceptualization of republican ideology contained important implications. Sundry forms of private property or capital could be used to determine republican citizenship, moving Virginians closer to the idea of the person-based democratic government advocated by reformers. This commodification of the freehold lessened its attractiveness for determining republican citizenship, requiring Virginians to search for a new litmus test. The belief that slaveownership and herrenvolk democracy could constitute that basis gained increased currency and acceptance across the state, as a racially based democracy would protect and strengthen chattel slavery. ${ }^{116}$ Slavery was not an obstacle to democratic reform, as argued by Willey; it became the essential ingredient.

The convention and new constitution hardened many northwestern residents' perspective of eastern politicians, planters, and slaveholding elites. Transmontane Virginians perceived little in the constitution that reflected the burgeoning democratic ethos that championed the cause of the "common man." Indeed, the constitution seemed antiquated and obsolete before the ink on its parchment dried. A Fourth of July reveler in Wheeling in 1830, hoped that the new constitution would enjoy a "short life" and that the "rights of man" in Virginia would soon

${ }^{116}$ Curtis, "Suffrage Reform in Virginia," 94-96. 
receive political representation. ${ }^{117}$ One historian describes the new constitution as "antediluvian, even in terms of its own times," inferring that it represented a counterrevolution of conservative and slaveholding interests and a stinging defeat for democratic proponents. ${ }^{118}$ But this mischaracterization overlooks the salient ideological, political, and practical changes manifest in the new constitution. The constitution was not "antediluvian"; rather, it represented a blending of nineteenth century conservative and progressive ideals, a reflection of delegates' awareness of a new economic and political context unfolding around them and the uneven march of democratic reform. More importantly, the new constitution accelerated Virginia's development as a modern slaveholding democracy, a movement that received increased support over the next few years.

${ }^{117}$ Wheeling Gazette, July 10, 1830, 3.

${ }^{118}$ Shade, Democratizing the Old Dominion, 70. 
Chapter 3: A Peculiar Détente: The Rise of Proslavery and Pro-Democratic Thought, 1830-1850

In 1850, Virginia appeared on the verge of dramatic political and constitutional reform.

Two decades after the conclusion of the previous constitutional convention, Virginians supported the convening of another body to once again reform the state's laws and (hopefully) address the “political degradation" experienced by many northwesterners. ${ }^{1}$ Randolph County lawyer and slaveholder David Goff presented one guiding principle to his representative to the convention, Gideon Draper Camden of Harrison County, a principle Goff believed would prove beneficial for all Virginians. ${ }^{2}$ "Let the East have any guarantee they want to protect their slave property," Goff insisted. Though he supported the "white basis," a platform opposed by many eastern Virginians, Goff supported constitutional safeguards and other political measures to protect eastern slaveholders' peculiar property. Indeed, Goff believed that the "white basis" and extra protection for slaveholders would "operate to the protection to the West as well as the East." White northwesterners would obtain the political equality they desired while eastern slaveholders would acquire greater protection on their chattel. Long desired sectional harmony would be achieved through a slaveholding democracy. ${ }^{3}$

What important changes over the previous two decades led to the 1850-1851 Constitutional Convention? Why did Goff declare unflinching support for extra "guarantee[s]" for eastern slaveholders, men who had long denied white northwesterners political and constitutional equality? These questions take on greater importance when they are considered alongside the anger and disappointment expressed by northwesterners following the ratification

\footnotetext{
${ }^{1}$ John Carlile to Jonathan M. Bennett, 17 January 1850, Jonathan M. Bennett Collection, A\&M 32, Box 6, item 1564, WVRHC.

21850 U.S. Federal Census, Randolph County, Virginia, Roll: M432_972; Page: 67A; Image: 137 [Ancestry.com] [accessed 30 March 2015]; 1850 U.S. Federal Census - Slave Schedules, Randolph County, Virginia [Ancestry.com] [accessed 30 March 2015]

${ }^{3}$ David Goff to Gideon D. Camden, 31 January 1851, Gideon D. Camden Collection, A\&M 1199, Box 2, Folder December 1850 to March 1851, WVRHC.
} 
of the 1830 Constitution. Historians exploring this episode in Virginia history have arrived at a general consensus that the failure to obtain democratic reforms in 1830 represented one of the mileposts on Virginia's road to eventual dismemberment. ${ }^{4}$ This anachronistic narrative, though, sacrifices contingency for convenience, specifically the convenience of knowing and confirming the conclusion of this important political and constitutional struggle. Goff's instructions to Camden and his belief in the symbiotic nature of slavery and democratic reform reveal the synthesis of two decades of important political and ideological developments in Virginia. Most notably, changes in political thought and the perceived increased dangers against slavery, including the rise of northern antislavery groups, during the 1830s and 1840s ultimately help lead Virginians to support a new constitutional convention.

The changes and issues that compelled Virginians to once again amend their constitution reflected national and state developments concerning slavery. National crises concerning slavery, notably the Wilmot Proviso, the Mexican-American War, and the rise of abolitionism in the North, convinced some eastern planters and politicians that constitutional reform would align the interests of nonslaveholders with those of slaveholders and promote unity among Virginians on the issue of slavery. In 1848, Governor William Smith announced his continued support for "revising our state constitution," arguing that the North's "oppressive policy" toward slavery

\footnotetext{
${ }^{4}$ Ambler, Sectionalism in Virginia, Bruce, Rhetoric of Conservatism, Freehling, Drift Toward Dissolution, Freehling, Secessionists at Bay, Shade, Democratizing the Old Dominion, and Link, Roots of Secession, are a few notable monographs that argue the denial of democratic principles in the 1829-1830 Constitutional Convention put the Old Dominion on a path toward dismemberment, with few, if any, serious attempts at sectional reconciliation. For these historians, differing economic, demographic, social, and political contexts between eastern and western Virginia proved too difficult to reconcile until Virginia's secession in 1861 compelled western Virginians to pursue the creation of a new state. In short, the national narrative of secession mirrored that unfolding in Virginia. Western Virginians, in essence, looked only for their opportunity to escape the clutches of eastern Virginians for over three decades, finally achieving their desire during the Civil War. As this chapter will argue, northwesterners pledged their loyalty to the state and all its institutions. Further, northwesterners advocated some form of political reconciliation through the state's most powerful institution, slavery.
} 
necessitated a united front among all white Virginians against such tyranny. ${ }^{5}$ The following year, Governor John B. Floyd echoed the sentiments of his predecessor. "[C]onstitutional reform will satisfy the demands of the people," Floyd concluded, and unite "all the interests of the Commonwealth." The "sooner" such reform could be "accomplished the better," he maintained. ${ }^{6}$ By closely linking constitutional reform with protecting slavery, Virginians cemented that symbiotic relationship and thus made any attack on slavery an assault on all Virginians' political independence.

Concerns over slavery within the state manifested, too, as threats to the peculiar institution seemed increasingly tangible and serious. ${ }^{7}$ Slaveholders across the state worried that abolitionists operated secretly within the state (and perhaps with aid from sympathetic nonslaveholders), helping slaves flee and indoctrinating blacks and whites with their dangerous and troubling beliefs. In September 1845, the Wood County Circuit Superior Court tried three Ohio residents arrested on providing "countenance, protection, and assistance to six negro slaves." Wood County's location on the Ohio River made it an attractive target for abolitionist activity and slaves hoping to flee to the North and possibly into Canada. These three Ohioans "feloniously entice[d], advise[d], and persuade[d]" the six slaves to "abscond and from the possession and service" of their master. Such subversive actions, Judge David McComas argued, threatened the "peace" and "stability" of Virginia. ${ }^{8}$

The threat of abolitionists invading the state amplified concerns that some nonslaveholding residents looked longingly for the end of slavery. In 1847, Washington College

\footnotetext{
${ }^{5}$ Journal of the House of Delegates, 1848-1849 (Richmond: Samuel Shepherd, 1848), 29.

${ }^{6}$ Journal of the House of Delegates, 1849 (Richmond: State Government Records Collection, Library of Virginia), 9-12, 16.

${ }^{7}$ William A. Link, Roots of Secession: Slavery and Politics in Antebellum Virginia (Chapel Hill: University of North Carolina Press, 2003), 15.

${ }^{8}$ Wood County Superior Circuit Court transcript, 1 September to 12 December 1845 , Wood County Records, A\&M 1752, WVRHC.
} 
President Henry Ruffner published his Address to the People of West Virginia, a tract that elucidated the political, economic, and social ills spawned by slavery. The immense and myriad ills produced by slavery required immediate action, he concluded. Ruffner supported gradual emancipation to prevent western Virginia from being overrun by African American slaves and, in the process, release westerners from the political power wielded by eastern slaveholders. Ruffner's plan garnered mainly negative reviews but nonetheless illustrated that such ideas, though relatively dormant since 1832, still received circulation within the nation's largest slaveholding state. Constitutional reform would hopefully ameliorate nonslaveholders' overt and clandestine attempts to undermine slavery and the power of the slaveholding regime while generating a united front against abolitionists' assaults.

The rise of Jacksonian Democracy during the 1820s and 1830s and the entrenchment of the two-party system across the South bolstered support for slavery, but in Virginia this narrative proved more complex. Proponents of Jacksonian Democracy in Alabama and Mississippi ratified and amended state constitutions so that by 1832 both states had established universal white male suffrage and increased the number of popularly elected political offices. ${ }^{9}$ In Tennessee and North Carolina, Jacksonians reformed their states constitutions in 1834 and 1835, respectively, removing vestiges of colonial and early republic limits on political participation. Most importantly, the new state constitutions excluded African Americans from politics and rejected any emancipation plan, preventing the few free propertied blacks that resided in those states from voting or allowing future freed slaves any opportunity of political representation. ${ }^{10}$ The democratic actions undertaken by these southern states promoted a formal hardening of

\footnotetext{
${ }^{9}$ Wilentz, Rise of American Democracy, 341.

${ }^{10}$ Lacy Ford, Deliver Us From Evil: The Slavery Question in the Old South (New York: Oxford University Press, 2009), 417-443.
} 
racial lines, a flattening of social and class distinctions among white men, and an increased commitment to "herrenvolk republicanism." the 1830s and 1840s across the slaveholding South, ensuring greater political independence for white men and a more ardent commitment to slavery.

Virginians experienced the effects of the two-party system. Partisan newspapers, party platforms, caucuses and nominating committees, and canvassing candidates were common sights throughout the state, including the Northwest. ${ }^{12}$ Though reformers lamented the suffrage restrictions imposed by the 1830 Constitution, the number of those eligible to vote increased and practically all white men could engage in party functions. But as politics increasingly emerged as the purview for white men across the slaveholding South, white, disenfranchised Virginians grumbled about their political exclusion. The disenfranchised felt the "unjust and injurious bearing" produced by the "foolish and anti-republican restriction upon the right of suffrage," a Parkersburg newspaper lamented. The lack of universal male suffrage represented one marker of Virginia's "constitutional misfortunes" that generated needless social and political divisions. These divisions, planters and slaveholders across the state feared, could eventually erode nonslaveholders' fealty toward slavery. ${ }^{13}$

In each reason that compelled Virginians to once again amend their constitution two decades after the previous revision, the same fundamental truth became manifest. Slavery and democracy for white man became inseparable and practically indistinguishable, a southern alloy that promised political and social independence and public and private power for all white men while generating an army of passionate defenders for chattel slavery. The defense of slavery

\footnotetext{
${ }^{11}$ Ford, Deliver Us From Evil, 417.

${ }^{12}$ Shade, Democratizing the Old Dominion, 9.

${ }^{13}$ Parkersburg Gazette and Western Virginia Courier, December 15, 1849, 2.
} 
invariably thus became a defense of democracy, with the inverse holding equally true. In the Northwest, the majority of residents, including men like David Goff, willingly embraced this political dynamic. Though some residents protested the inordinate power wielded by slaveholders and the political "double security" placed on chattel property, the outcry against slavery was minimal and isolated, especially after $1832 .{ }^{14}$ Northwestern residents understood and accepted the southern axiom that political liberty for white men depended on enslaved African Americans.

In the immediate aftermath of the ratification of the 1830 Constitution, the clamor over annexation, demands for another constitutional convention, and even rumors of violent resistance quickly faded by the end of the year. Various reasons existed for this decrease in tensions. "A dismemberment of the old dominion is to be deprecated," one northwestern resident stated, believing that the national and state political ills produced by such action would outweigh possible benefits. ${ }^{15}$ Other western Virginians provided an optimistic perspective on the new constitution. Within scathing reviews of the new constitution, critics often applauded the new requirements for suffrage, noting that the "right of suffrage is extended" before focusing on the constitution's drawbacks. ${ }^{16}$ Though not possessing all the democratic principles advocated by reformers, the 1830 Constitution represented "one great step towards a perfect reform of the government." Western Virginia's continued demographic growth and economic expansion would eventually compel eastern Virginians to accept democratic reforms, residents maintained. The new constitution represented a minor and temporary setback in democracy's eventual triumph. ${ }^{17}$

\footnotetext{
${ }^{14}$ Proceedings and Debate, 75.

${ }^{15}$ Wheeling Gazette, November 6, 1830, 3.

${ }^{16}$ Wheeling Compiler, March 24, 1830, 3.

${ }^{17}$ Virginia Free Press [Charles Town], March 10, 1830, 3.
} 
Other northwestern residents expressed tangible concerns about annexation to Pennsylvania, Ohio, or Maryland. Residents in Wheeling worried about the economic ramifications of annexation to Pennsylvania, as the city competed with nearby Pittsburgh for national prestige, economic power, and commercial clout. ${ }^{18}$ "What would Philadelphia and Pittsburgh agree to do for Wheeling and Clarksburg?"19 Though many residents still believed that politicians in Richmond attempted to stifle Wheeling's economic growth and political clout, securing financial support in the Keystone State would be highly competitive and uncertain. Wheeling politician Archibald McClean believed that the bluster surrounding annexation and the dissatisfaction with the constitution emerged from a vocal and disgruntled minority. If the "whole voice" of the Northwest could speak on this issue, he insisted, "a different result" would be manifest. The supposed "undivided voice" of the Northwest, while manifest in the years preceding the convention, fractured as residents began to appreciate how the new constitution furthered their respective interests. Self-interest, not political principles, swayed many residents. ${ }^{20}$ The immediate response to the new constitution varied across the Northwest. Many residents pined for another convention that would implement democratic reform and liberate the "politically cursed" majority. ${ }^{21}$ Still others accepted the constitution's provisions, enjoying the extension of suffrage while dismissing possible alternatives. The supposedly monolithic Northwest once again illustrated its political diversity.

Any further discussion of the 1830 Constitution quickly faded by 1831 as news of the Southampton uprising in August reached the Northwest. ${ }^{22}$ Nat Turner's rebellion in Southside

\footnotetext{
${ }^{18}$ Barnes, "Urban Rivalry in the Upper Ohio Valley."

${ }^{19}$ Wheeling Compiler, December 1, 1830, 3.

${ }^{20}$ Wheeling Compiler, November 17, 1830, 3.

${ }^{21}$ Wheeling Gazette, July 10, 1830, 3.

${ }^{22}$ For an overview of the Nat Turner Rebellion, see Ford, Deliver Us From Evil, 338-349.
} 
Virginia, outside of its human cost, challenged the emerging southern ideology of paternalism. Paternalism, a lower South remedy to the quandary of slavery and Christianity, progressed in starts and fits. In the Old Dominion, few openly accepted paternalism, with most adherents residing in the heavily slave-populated Tidewater and Southside regions. The majority of Virginia slaveholders, according to Lacy Ford, argued that sagging economic profits demonstrated the limitations of a slave-based economy, leaving some in the state searching for a way to remove slaves and free blacks. ${ }^{23}$ Turner's rebellion appeared to provide that opportunity.

Virginia Governor John B. Floyd proposed a plan to remove all African-Americans from the state. In a letter to South Carolina Governor James Hamilton, Jr., Floyd stated he would support legislation curtailing slaves' mobility. This included confining slaves to their masters' plantations, prohibiting all black preaching, and removing all free African-Americans from the state. ${ }^{24}$ This short-term solution, Floyd hoped, would preclude imitators and calm white Virginians' fears about another revolt. His long-term solution appeared more polarizing. He proposed using surplus state revenue to remove all blacks from Virginia, a "first step to emancipation." Floyd assured Hamilton he would proceed "tenderly and cautiously," and invited responses from the South Carolina governor and Georgia's governor, too. ${ }^{25}$

Floyd's plan for emancipation may not have been as audacious as it first appeared.

Virginia, like Maryland and Delaware, initiated steps in the late eighteenth and early nineteenth centuries to decrease its slave population. For example, in 1816 the Virginia Legislature quietly endorsed colonization and private manumission as part of a larger program to "whiten" the upper

\footnotetext{
${ }^{23}$ Ford, Deliver Us From Evil, 350-360.

${ }^{24}$ Quoted from Charles Ambler, The Life and Diary of John Floyd: Governor of Virginia, an Apostle of Secession, and The Father of the Oregon Country (Richmond: Richmond Press, 1918), 90.

${ }^{25}$ Ambler, John Floyd, 90. Unfortunately, there are no extant records indicating the responses of either lower South governor.
} 
South through demographic reconfiguration. Northwestern residents generally supported this demographic reconfiguration. Parkersburg lawyer Peter G. Van Winkle supported colonization, echoing economic arguments that the "value of slave labor has probably reached its maximum." This realization would eventually compel slaveholders to rid themselves of their chattel. Rather than being inundated with a population of "free blacks" who exhibited a "tendency to crime," removing such a troublesome population became the "duty of the country." ${ }^{26}$ A large majority of northwestern residents supported colonization, characterizing colonization societies as "humane and liberal" as they offered African Americans the opportunity to return to their ancestral home civilized and Christianized. ${ }^{27}$ Once in Africa, these colonized men and women would elevate the "political and moral character" of their continent. ${ }^{28}$ This process of "whitening" Virginia would remove "a black population [northwesterners] do not want," stop the illegal smuggling and importation of slaves to the Deep South, and invalidate the "unnatural and unpatriotic" northern doctrine of abolitionism. ${ }^{29}$

In the Northwest, the public reaction to the fallout from Nat Turner's rebellion remained cautiously guarded. In Morgantown, the Monongalian reprinted a memorial from Richmond slaveholders petitioning the state legislature for inaugurating some means of removing free blacks and colonizing slaves. The "existing curse of slavery" demanded immediate attention, lest the increasing free and enslaved populations eventually overrun Virginia's white population. ${ }^{30}$ The editor of the Monongalian also rebuked any discussion of revisiting a division of the state in the wake of Nat Turner's rebellion. ${ }^{31}$ In Wellsburg, the editor of the Wellsburg

\footnotetext{
${ }^{26}$ Undated speech, Peter G. Van Winkle Collection, A\&M 136, Box 1, WVRHC.

${ }^{27}$ Wheeling Gazette, July 31, 1830, 3.

${ }^{28}$ Harrison County Whig and Western Virginia Advertiser, August 31, 1843, 2.

${ }^{29}$ Western Virginia Times \& Advertiser, February 19, 1840, 1.

${ }^{30}$ Monongalian, November 19, 1831, 2.

${ }^{31}$ Monongalian, December 3, 1831, 2.
} 
Gazette republished an article from the Niles Weekly Register that advocated emancipation with removal. ${ }^{32}$ Few men attacked slavery outright and none demanded its immediate abolition. Indeed, one of the few public attacks on slavery centered on its "deleterious" economic effects, a sentiment that previous generations of Virginians had articulated. ${ }^{33}$ Economic concern may have proven to be the most important for many northwestern residents but not because of slavery's effect on the state's overall economy. Newly emancipated slaves, if not removed or colonized, could, along with free blacks, head north in search of employment. African Americans would flood local job markets, depress wages, and increase unemployment among white men. Growing industrial cities such as Wheeling and, to a lesser extent, Wellsburg, could represent a possible destination for these emancipated former slaves. Unless an ironclad agreement could be reached that ensured the removal of all emancipated African Americans from the state, many northwestern residents remained pessimistic about emancipation's efficacy.

Residents around Charleston expressed similar concerns but noted the possible political ramifications of emancipation. For numerous years, Judge Lewis Summers decried, "eastern gentlemen" acquired their "political power either as derived from the slave population, or under the pretext of guarding that species of property." Yet he worried about the larger, possibly unforeseen consequences of emancipation. If delegates pushed too hard and actually achieved emancipation, Summers worried "nothing will be left for rail-roads or canals in any quarter."34 After appropriating capital for removing free blacks and slaves, the state government would have little left in the treasury for internal improvements for western Virginia. Even the prospect of voting for emancipation could prove dangerous. Eastern politicians could "make reprisals"

\footnotetext{
${ }^{32}$ Wellsburg Gazette, September 30, 1831, 3.

${ }^{33}$ Wellsburg Gazette, February 2, 1832, 3.

${ }^{34}$ Lewis Summers to George Summers, 27 January 1832, Lewis and George Summers Papers, A\&M 1791, Box 1, Folder 1, WVRHC.
} 
against the west "for its course on the slave question," a dangerous proposition considering the immense power wielded by such men. ${ }^{35}$ Instead of advocating for emancipation, Summers remarked that considering slavery's position in electoral politics and its future in Virginia "may be the work of time." 36

The debate over slavery and emancipation unfolded in the state legislature during the winter of 1832, exhibiting similar sectional divisions as those present during the 1829-1830 Constitutional Convention. ${ }^{37}$ Across the Tidewater and Piedmont, proslavery advocates sought to minimalize the threat of insurrection and quash talk of emancipation. Many of these legislators supported removing free African Americans, a group they viewed with suspicion. In areas with few slaves, including the Northwest, delegates took a strong stance for emancipation and removal, reminding their colleagues that slavery retarded economic growth and precluded democratic reform. ${ }^{38}$ Accordingly, northwesterners coalesced around Thomas Jefferson Randolph's post-nati plan. ${ }^{39}$

Most western delegates openly professed their disdain for chattel slavery, arguing that this "cancer on the political body" required immediate removal lest the symptoms worsen. ${ }^{40}$ Other western delegates reminded their colleagues that their section cared "deeply" about the outcome of this debate, rebuking arguments that slavery represented an issue solely for eastern

\footnotetext{
${ }^{35}$ Lewis Summers to George Summers, 10 February 1832, Lewis and George Summers Papers, A\&M 1791, Box 1, Folder 1, WVRHC.

${ }^{36}$ Lewis Summers to George Summers, 28 February 1832, Lewis and George Summers Papers, A\&M 1791, Box 1, Folder 1, WVRHC.

${ }^{37}$ Freehling, Drift Toward Dissolution.

${ }^{38}$ Shade, Democratizing the Old Dominion, 197.

${ }^{39}$ Thomas Jefferson Randolph, The Speech of Thomas J. Randolph in the House of Delegates of Virginia, on the Abolition of Slavery (Richmond: Thomas W. White Press, 1832), 8. Randolph's full proposal included a deportation plan that would rid the state of all African-Americans. Female slaves born after July 4, 1840 would be freed at eighteen, twenty-one years of age for males. Following emancipation, former slaves would join already free African-Americans and become wards of the state. They would labor as wards until they earned enough money to offset the costs of shipping them to Africa.

${ }^{40}$ Henry Berry, The Speech of Henry Berry, (Of Jefferson), in the House of Delegates of Virginia, on the Abolition of Slavery (Richmond: Thomas W. White Press, 1832), 2.
} 
Virginians to debate. ${ }^{41}$ Kanawha County delegate George W. Summers emerged as an avid proponent of emancipation and colonization, believing that the removal of African Americans would eventually beget political equality for white westerners. Slavery, he declared, poisoned slaveholders' republican values, producing the "embryo tyrant of its little domain" while inculcating "abusive epithets" within masters. When property rights came in conflict with the common weal, he averred, the former must yield to the latter. ${ }^{42}$ Brooke County representative John C. Campbell, a disciple of Philip Doddridge, supported voluntary colonization, reflecting his constituents' demand of "whitening" the state and protecting white, laboring northwesterners. To manifest these demands, Campbell worked during the debates to secure sufficient funding for transporting African Americans outside of Virginia. ${ }^{43}$

Eastern representatives, especially those from the Southside, attempted to downplay Nat Turner's rebellion. As Lacy Ford argues, these delegates portrayed the rebellion as an isolated incident that the militia quickly extinguished. Governor Floyd, while a westerner, echoed this interpretation. The "banditti of slaves" never constituted a significant numerical group, and their reign of terror lasted only twenty-four hours. Once alerted, local citizens and militia groups "speedily terminated" these "deluded fanatics." 44 Other slaveholding proponents, including Wiliam O. Goode of Mecklenburg County and James H. Golson from Southside Virginia, wielded similar arguments as those espoused during the previous constitutional convention. Specifically, they deflected assertions that slavery stifled economic growth, blaming instead the

\footnotetext{
${ }^{41}$ Charles James Faulkner, The Speech of Charles Jas. Faulkner, (Of Berkeley) in the House of Delegates of Virginia, on the Policy of the State with Respect to Her Slave Population (Richmond: Thomas W. White, Printer, 1832), 7.

${ }^{42}$ Quoted in Ford, Deliver Us From Evil, 372 and Shade, Democratizing the Old Dominion, 197.

${ }^{43}$ Shade, Democratizing the Old Dominion, 199.

${ }^{44}$ Journal of the House of Delegates of the Commonwealth of Virginia, Begun and Held at the Capitol, in the City of Richmond, on Monday, the Fifth Day of December, One thousand Eight hundred and Thirty-one (Richmond:

Thomas Ritchie, Printer, 1831), 9.
} 
Tariff of 1828 and meddlesome abolitionists and other outside agitators. True safety, such men averred, could be achieved by removing the state's free African American population, not slaves. $^{45}$

As during the previous constitutional convention, numerous eastern delegates denied that western nonslaveholders deserved a voice in this debate. Western Virginians possessed "no pecuniary interest" in slavery and only sought emancipation as a means of inaugurating the dreaded "white basis" that eastern delegates defeated two years earlier. ${ }^{46}$ This debate over slavery "chiefly and peculiarly" affected eastern Virginians, especially since the "farmers and graziers" of western Virginian needed only a "few slaves" to perform the "menial, domestic" tasks. The minimal impact of slavery on western Virginia's economy and society paled in comparison to the slave society of eastern Virginia. ${ }^{47}$ Some men echoed Upshur's assertion that a "rooted antipathy" against slavery existed among western Virginia's hollows and hills, and residents sought only the opportunity to strike against the institution. If this variant of antislaveryism could not be quarantined to the western side of the Alleghenies, Goode warned, a division of the state would emerge as the only possible remedy. ${ }^{48}$

Most delegates generally agreed that emancipation and removal through colonization would, in the end, preserve the Old Dominion as a white man's republic. But they divided over the means to achieve that end. ${ }^{49}$ Virginians were acutely aware of the burdensome costs associated with colonization, and slaveholders across the state posited that taxes needed to support such a plan would come from their pockets. This form of government overreach worried

\footnotetext{
${ }^{45}$ Shade, Democratizing the Old Dominion, 198-199.

${ }^{46}$ William H. Brodnax, The Speech of William H. Brodnax (of Dinwiddie) in the House of Delegates of Virginia, on the Policy of the state with respect to its colored population (Richmond: Thomas W. White Press, 1832),18-19.

${ }^{47}$ John Thompson Brown, Speech of John Thompson Brown on the Abolition of Slavery, Delivered Wednesday, January 18, 1832 (Richmond:Thomas W. White, Printer, 1832), 13-14.

${ }^{48}$ Rice and Brown, West Virginia, 103.

${ }^{49}$ Freehling, Drift Toward Dissolution, 159.
} 
even the most ardent emancipationists, including those in the Northwest. ${ }^{50}$ Randolph's plan constituted an "unconstitutional and unrepublican confiscation of property" that lacked compensation, endangered the "exclusionary" right of private property, and could ultimately establish a dangerous precedent on future political and constitutional actions. ${ }^{51}$ Ultimately, such drawbacks proved the unraveling of Randolph's post-nati plan and other emancipation proposals. ${ }^{52}$ Northwestern delegates salvaged a political victory, though, voting unanimously for a resolution that laid the groundwork for colonizing free African Americans. This proposal, passed by the state legislature, evinced northwesterners hopes for a "whitened" Virginia. ${ }^{53}$

Few Virginians felt satisfied at the conclusion of these debates. Conservatives reproached each other for permitting western nonslaveholders to broadcast their disdain for slavery. Northwestern delegates, while pleased to obtain a tentative plan for the removal of African Americans, hoped the debates would awaken Virginians from their "fatal lethargy on this subject."54 A Wellsburg resident, reflecting on these debates, aptly captured his neighbors' sentiments regarding slavery. In a series of letters published in the Brooke Republican, "W.T.W" spoke plainly about slavery's effects on the state. ${ }^{55}$ The author stated unequivocally that slavery deluded Virginians into supporting the dangerous doctrines of nullification and secession, believing that the latter two spawned from a desire to protect the peculiar institution. Northwestern Virginians, to avoid being dragged into such a perilous situation, should adopt all "honest measures to prohibit...the dark tide of slavery" from washing over their region. These

\footnotetext{
${ }^{50}$ Ford, Deliver Us from Evil, 379.

${ }^{51}$ Curtis, Jefferson's Freeholders, 141; Ford, Deliver Us from Evil, 368; and Shade, Democratizing the Old Dominion, 198.

${ }^{52}$ Curtis, Jefferson's Freeholders, 141.

${ }^{53}$ Wilentz, Rise of American Democracy, 346.

${ }^{54}$ Berry, Speech of Henry Berry, 2.

${ }^{55}$ Extant evidence suggests that Waitman Thomas Willey was the author of these letters. Along with the initials, Willey lived in Wellsburg during the publication of these letters. Further, Willey wielded similar arguments as those published in the Brooke Republican during his political career.
} 
measures included emancipation and colonization along with a vigorous interstate slave trade. ${ }^{56}$ Northwesterners "should lend ready assistance" to eastern Virginians in achieving this important goal, even conceding to eastern Virginians sole discretion on state laws concerning slavery. Refusal on the part of eastern Virginians to "whiten" the state could compel northwesterners to pursue a division of the state. ${ }^{57}$

As with other western representatives during the debates over slavery, "W.T.W" believed that emancipation and removal would protect the white, laboring northwesterner. While a proponent of emancipation, "W.T.W." believed that manumission should occur gradually lest the Northwest be inundated with a "vast mass of miserable population, deplorably ignorant and utterly incapable" of self-sufficiency. The "intelligent laboring classes" of the region would invariably suffer. Western arguments demanding political representation for their labor would be undermined by African Americans who would depress wages, increase competition, and devalue manual labor. ${ }^{58}$ If emancipation could not be properly paired with colonization, then African Americans should remain in bondage. ${ }^{59}$

The removal of African Americans from Virginia would also promote sectional harmony. Slavery brought eastern interests "into direct conflict, with the interests of the west," this Wellsburg resident insisted, with internal improvements, political representation, and public education presented as casualties in this political strife. Only two alternatives existed for producing "an identity of policy" for Virginians. Either western Virginians would yield and purchase slaves until their society mirrored that of eastern Virginia or the slaveholders east of the

\footnotetext{
${ }^{56}$ Brooke Republican, June 12, 1833, 3.

${ }^{57}$ Brooke Republican, June 19, 1833, 1.

${ }^{58}$ Brooke Republican, June 12, 1833, 3.

${ }^{59}$ Brooke Republican, June 12, 1833, 3.
} 
Blue Ridge would emancipate themselves from slavery, making the Old Dominion a free state. ${ }^{60}$ Racial purity, employment for white men, republican virtue, and sectional harmony demanded some form of action, "W.T.W" concluded. Having failed to adequately address these concerns, northwesterners then could seek a division of the state, the final act in this intrastate drama.

Historians interpreting the 1832 Virginia Legislature Debates have generally agreed that these debates presaged Virginia's eventual dismemberment. The threat to divide the state because of Virginians' inability to resolve the issue of slavery appear to reaffirm that interpretation. The "breach" between western nonslaveholders and eastern slaveholders "widened" as a consequence of the debates, Sean Wilentz asserts, foreshadowing both the state and national crisis over slavery in $1860 .^{61}$ Alison Goodyear Freehling traces Virginia's "dissolution" into two states during the Civil War to these debates, as western, pro-democracy reformers battled eastern, aristocratic slaveholders for control of the state legislature, political power, and the future of the Commonwealth. The inability for these two factions to coexist, according to Alison Freehling and William Freehling, clearly illustrated a "white community irrepressibly divided by slavery," a debilitating internal division that continually resurfaced and later weakened the Confederate States of America. ${ }^{62}$ William Shade's core-periphery analytical paradigm adds greater nuance to the clear sectional division posited by Alison Freehling, but he also argues that subsequent discussions over slavery in Virginia followed the same general contours sketched out by Virginians during this debate. ${ }^{63}$

\footnotetext{
${ }^{60}$ Brooke Republican, June 19, 1833, 1.

${ }^{61}$ Wilentz, Rise of American Democracy, 347. For a similar interpretation, see also Daniel Walker Howe, What Hath God Wrought: The Transformation of America, 1815-1848 (New York: Oxford University Press, 2007), 326. Howe argues that the "bifurcation" of Virginia into two states during the Civil War can be traced back to these debates over slavery.

${ }^{62}$ Freehling, Drift Toward Dissolution, xiii; Freehling, Secessionists at Bay, 1776-1854, 178-196; Freehling, South vs. the South.

${ }^{63}$ Shade, Democratizing the Old Dominion, 197.
} 
This historiography suffers from an anachronistic perspective. Aware of West Virginia's separation from Virginia during the Civil War, historians have searched for antecedents to that movement, sacrificing contingency and context for a selective reading of the evidence. Dissatisfaction arising from the 1832 Virginia Legislature Debates and threats of division from the Northwest, for example, seemingly represent an important milepost on the road to "dissolution." When considered alongside the previous constitutional convention, West Virginia's separation appears inevitable. But Virginians were not privileged with such information. Rather, many placed their faith in the marketplace and the legislature's voluntary emancipation scheme to begin the deliberate, if slow, process of "whitening" the state. This demographic reconfiguration would not be achieved overnight, residents understood. Further, talk of division represented an ultimatum or last resort designed to impress upon eastern slaveholders the severity of political injustice suffered by northwesterners. Only after exhausting all political and constitutional options would northwesterners have explored a division of the state.

The true legacy of the 1832 Virginia Legislature Debates emerged from the writings of proslavery advocates Benjamin Watkins Leigh, Thomas Roderick Dew, and Abel Parker Upshur, not in the seemingly inevitable "dissolution" of the Old Dominion. In the span of a few years, these men witnessed slavery come under increasing attack both from within and without. Eastern delegates fended off accusations in the 1829-1830 Constitutional Convention that slaveholders and freeholders wielded inordinate power to the detriment of political representation for white men. While eastern delegates defeated reform initiatives such as universal suffrage and equal representation, the freehold underwent a dramatic redefinition that broadened the electorate but diminished its political viability. Two years later, Virginians 
revisited slavery and its role in the state, with many westerners advocating some means of emancipation and removal. Once again, easterners closed ranks and defeated serious, detailed proposals that called for slavery's eventual removal. Even with these political victories, slavery's future in Virginia appeared uncertain.

The internal political debates over slavery emerged as national discussions over slavery came to the forefront. ${ }^{64}$ The rise of immediate abolitionism in the North, the "Tariff of Abominations," South Carolina's threat of nullification and secession, and David Walker's bellicose Appeal to the Colored Citizens of the World impressed upon proslavery advocates that opposition to slavery appeared increasingly tangible and militant. Few solutions seemed to exist to convince Virginians of the need to maintain slavery and confront threats to the institution. The "positive good" argument posited by Deep South politicians, clergy, and residents had failed to gain traction in Virginia outside of the Tidewater and Southside. Eastern slaveholders' economic arguments about slavery's profitability rang hollow, especially considering the state remained mired in a depression. ${ }^{65}$ Rather, Leigh, Dew, and Upshur sought to recast slavery as essential to republican government. These theorists saw slavery as a wellspring and model of republican virtue, not tyranny. Further, they wanted slaveholding to replace the freehold as the basis for republican citizenship and government, thereby representing the source of political freedom and independence for white men. Slavery's future would be tethered to that of the state, providing the greatest security possible for the peculiar institution.

\footnotetext{
${ }^{64}$ William Shade rightly acknowledges that Virginians mounted an aggressive defense of slavery following the debates in 1832, with some of the most prominent proslavery ideologues emerging in the debate's aftermath. However, Shade does not connect this ardent defense of slavery to changes made to suffrage requirements during the previous constitutional convention. Rather, as I argue, the rising defense of slavery emerged from both the debates over slavery and the constitutional convention, and offered a means of protecting slavery by tethering nonslaveholders' political representation and independence to slavery.

${ }^{65}$ Dunn, Dominion of Memories, 9-10.
} 
Leigh, Dew, and Upshur's campaign to reconceptualize slaveholding as the source of republican citizenship signaled an important political and constitutional shift. The democratization of southern state governments in the 1830s, notably in Tennessee and North Carolina, occurred concomitantly with a more aggressive defense of slavery. Democracy for white men and slavery for African Americans became inseparable, existing in a powerful symbiotic relationship that flattened class distinctions and promoted unity between nonslaveholders and slaveholders. This dynamic would unfold in Virginia, too. The "whitening" sought by northwestern residents would not be achieved solely through demographic shifts but through the manifestation of "herrenvolk republicanism."

Benjamin Watkins Leigh served as the principal figure in refashioning a defense of proslavery republicanism by replacing the freehold with slavery as the basis for republican government. In his 1832 Letter of Appomatox [sic], Leigh reflected on the Virginia Legislature Debates over slavery, scolding delegates for mischaracterizing the evils of slavery and for their reckless discussion of seizing private property. Leigh mocked the supposedly divine revelations received by Turner, insisting instead that a "hallucination" seized the slave and distorted his moral compass. ${ }^{67}$ Any subsequent insurrections would not be traced back to "hallucinations," the "incendiary writings" of northern abolitionists, or the "seditious practices of negro preachers," he warned. The blame would fall upon the "measures proposed" and the "speeches delivered, in our own legislature." ${ }^{98}$ Indeed, Virginians needed to stop the wild and irresponsible talk of abolition, emancipation, and removal lest slaves internalize these words and pursue

\footnotetext{
${ }^{66}$ Ford, Deliver Us From Evil, 417.

${ }^{67}$ [Benjamin Watkins Leigh],The Letter of Appomatox to the People of Virginia: Exhibiting a Connected View of the Recent Proceedings in the House of Delegates, on the subject of the Abolition of Slavery; and a Succinct Account of the Doctrines Broached by the Friends of Abolition, in Debate; and the Mischievous Tendency of those Proceedings and Doctrines (Richmond: Thomas W. White, Printer, 1832), 3.

${ }^{68}$ [Leigh], Appomatox, 21.
} 
freedom through their own means. Leigh proposed an increased militia presence and greater vigilance among citizens, including nonslaveholders, to prevent another slave rebellion. ${ }^{69}$

Leigh also refuted delegates' assertions about slavery's degrading effects on the white population. Though New England enjoyed a superior system of “elementary education," Leigh dismissed thoughts that slavery's absence resulted in educated and literate residents. Moreover, talk of slavery corroding morals or producing the "embryo tyrant of its little domain," as suggested by George Summers, represented a "pernicious" exercise that focused on the few evil deeds publicized by delegates and sympathetic newspaper editors. Greece and Rome, both slaveholding societies, represented the acme of manners and civilization. ${ }^{70}$ Delegates, including those from the Tidewater and Piedmont, had "exaggerated" the evils generated by slavery, confirming westerners' assertions that the health of the republic depended on slavery's abolition. Indeed, these "unwise, [and] ill-judged" mischaracterizations of slavery undermined easterners' defense of slavery, providing an opportunity for opponents of slavery to exploit. Leigh implored slaveholders to broadcast slavery's benefits, believing that such efforts would appease nonslaveholders and quiet any discussion of emancipation. ${ }^{71}$

As Christopher Michael Curtis has noted in his interpretation of the Letter of Appomatox, Leigh avoids any defense of private property in terms of the freehold. Rather, Leigh situated private property in slavery and the master-slave relationship at the center of republican government. ${ }^{72}$ Delegates' plans for emancipation represented a "violent abrogation of the rights of slave property without the consent of its owners."73 The dangerous and revolutionary

\footnotetext{
${ }^{69}$ [Leigh], Appomatox, 7.

70 [Leigh], Appomatox, 22-23.

71 [Leigh], Appomatox, 21.

72 Curtis, Jefferson's Freeholders, 129-130, 146 and Curtis, "Reconsidering Suffrage Reform," 123.

73 [Leigh], Appomatox, 11.
} 
proposals advanced by emancipationists lacked authorization from slaveholders, violated state law concerning private property, and appeared to validate the "tyranny of the majority." Slaveholders possessed an invested right in their current slaves and their future increase, a fundamental law that the "legislature cannot constitutionally take away." Leigh's conclusions were clear. Slaveholders' rights to their chattel were "inviolable," deserving of constitutional and political safeguards to keep it safe from the "power of the public.""74 Indeed, the health of Virginia's republican government depended on the protection of such rights.

The fruits of Leigh's Letter of Appomatox would not be manifest for some time. But his argument that slavery represented a "positive source of republican virtue" and required constitutional safeguards in order to protect it and, by extension, the republic, occurred at a critical moment in Virginia and national politics. ${ }^{75}$ With opposition to slavery and slaveholders increasing, proslavery Virginians needed an ideological defense of the peculiar institution that would ensure its longevity and generate passionate supporters. By tethering slavery to the republic's health, Leigh proposed a powerful symbiotic relationship that would ensure slavery's survival. Few, if any, would attack slavery if it constituted a cornerstone of the state government. Further, by championing the virtues that emanated from the master-slave relationship, Leigh sought to discredit abolitionists from without and emancipationists from within. Finally, his defense of slavery reflected his abandonment of the freehold, providing an opportunity for future constitutional reform on suffrage and political representation. Slavery, not the freehold, would serve as the guarantor of republican virtue and the basis for republican citizenship.

\footnotetext{
74 [Leigh], Appomatox, 16.

${ }^{75}$ Curtis, Jefferson's Freeholders, 148.
} 
William \& Mary Professor Thomas Roderick Dew furthered this reconceptualization of republican government championed by Leigh. In his Review of the Debate in the Virginia Legislature of 1831 and 1832, Dew dismissed emancipation and colonization schemes, extolled the civilization of African Americans in the United States, and offered a pro-democracy theory based upon slavery. Dew found common ground with Leigh. Both men rejected Thomas Jefferson's assertion that slavery corrupted the moral character of the slaveholder and, by extension, the republic. Further, both Leigh and Dew perceived in the master-slave relationship the necessary attributes for republican citizenship. Masters, Dew maintained, acted "humanely" and were "kind and indulgent" to their slaves. ${ }^{76}$ Indeed, the master introduced the "exalted principles of morality and religion" to his slaves, principles the master and slave continually refined during their interactions. ${ }^{77}$ The examples of cruel masters, such as those paraded out by western delegates, illustrated that those slaveholders failed to understand the nuanced masterslave relationship. Dew traced this failure to white northerners who married into slaveholding families, reaffirming his argument that a dearth of political virtue resulted from slavery's absence. ${ }^{78}$ A healthy republican government depended on the exceptional virtues that emanated from slavery and the master-slave relationship, notably benevolence and stewardship. ${ }^{79}$

The benefits of slavery and the master-slave relationship extended to all white men, too, offering equality and independence to nonslaveholders. Liberty for freemen, Dew contended, burned brightly in ancient slaveholding societies such as Rome and Greece because freemen possessed an intimate understanding of bondage. An identical dynamic prevailed in the

\footnotetext{
${ }^{76}$ Thomas R. Dew, Review of the Debate in the Virginia Legislature of 1831 and 1832 (Richmond: T.W. White, 1832), 108.

${ }^{77}$ Dew, Review of the Debate, 109.

${ }^{78}$ Dew, Review of the Debate, 109.

${ }^{79}$ Curtis, "Reconsidering Suffrage Reform," 123.
} 
slaveholding South. A "perfect spirit of equality so prevalent among the whites" demonstrated the great leveling effects of slavery. Because African American slaves occupied the "low and menial offices," the "distinctions" that wracked nonslaveholding societies were practically nonexistent in slaveholding states. ${ }^{80}$ Race was the only "distinction" that existed. "Color alone," Dew proclaimed, represented the sole "badge of distinction... and all who are white are equal in spite of the variety of occupation." The political implications were profound. The "spirit of equality" that characterized slaveholding societies also represented the "generator and preserver...of liberty." ${ }^{\prime 1}$ With all other distinctions subsumed by slavery, Virginians could inaugurate a racially based, democratic polity that offered independence for all white men and increased protection for slavery. Democracy and slavery would more than coexist; they would strengthen each other.

Eastern Shore politician and John C. Calhoun ally Abel Parker Upshur complemented this emerging proslavery discourse seven years later. Upshur posited that racial slavery refined the characteristics of benevolence and stewardship, two important qualities required for a republican government. Slaveholding "prepare[s] [the master] for the love of freedom, and to fit him for the enjoyment of it," Upshur declared. ${ }^{82}$ Slaveholders possessed "more elevated principles, a wider expansion of thought, a deeper and more fervent love, and a juster estimate of...liberty," a reflection of the exceptional qualities derived from slavery. ${ }^{83}$ The master-slave relationship equipped slaveholders with the ability to judiciously and fairly mete out punishment and justice, ensuring the health of their republican government, the safety of their neighbors, and the perpetuation and stability of their patriarchal world. Indeed, the "personal independence and

\footnotetext{
${ }^{80}$ Dew, Review of the Debate, 112. Dew's argument here presaged Henry Hammond's “mud-sill" speech.

${ }^{81}$ Dew, Review of the Debate, 113.

${ }^{82}$ Abel Parker Upshur, "Domestic Slavery," Southern Literary Messenger, (October 1839): 678.

${ }^{83}$ Upshur, "Domestic Slavery," 681.
} 
self-respect" derived from "the relation between master and slave" provided the strongest foundation for "political liberty." ${ }^{\prime 4}$ And with slavery constituting the foundation of a healthy republican government, white men sought to "preserve unbroken" that relationship that bestowed political independence. ${ }^{85}$

White men also sought to "preserve unbroken" the master-slave relationship and slavery in general because of the social benefits derived from the peculiar institution. Upshur, like Dew, posited that slavery flattened social distinctions among white men, generating a powerful sense of equality. "Here the slave is black, and the white man is never a slave," he remarked. Indeed, the "color of the slave," he proclaimed, that "eternal, ineffaceable distinction of nature" bestowed independence for white men and bondage for African Americans. Regardless of how "poor, or ignorant or miserable" a white man may be, the presence of African American slaves ensured a certain level of respectability and status in the community ${ }^{86}$ Moreover, white men could exercise mastery without being a slaveholder. A white nonslaveholder wielded "absolute authority over the negro, and...receive[d] from him continual proofs of deference and respect." ${ }^{87}$ Renting a slave elevated a nonslaveholder into the social ranks of the master class, allowing him to experience the southern ideal of mastery. This temporary entry into the master class increasingly aligned the interests of slaveholders and nonslaveholders, ensuring greater security for the institution that provided social independence and freedom for white men.

Virginians needed to support and maintain slavery, Upshur concluded, because the institution prevented the farcical and dangerous doctrines of abolitionism from upsetting racial hierarchy. The presence of African American slaves cultivated an acute sense of "independence,

\footnotetext{
${ }^{84}$ Upshur, "Domestic Slavery," 678.

${ }^{85}$ Upshur, "Domestic Slavery," 683, 678.

${ }^{86}$ Upshur, "Domestic Slavery," 678. [emphasis in original]

${ }^{87}$ Upshur, "Domestic Slavery," 678.
} 
freedom, and equality among all classes" of white men. The political spirit that emerged from this dynamic was not "that rude and levelling democracy, which seeks to establish a perfect equality." Northern states, under the corrupting influence of abolitionism, had begun to inaugurate this "perfect equality" in their society. Rather, white southerners enjoyed a "republican equality" that permitted white men and only white men to participate ${ }^{88}$ The benefits of slavery touched and supported white southerners in a myriad of ways, thus demanding vigilance and fealty from white southerners every day.

The proslavery defenses promulgated by Leigh, Dew, and Upshur reflected Virginia's changing political, economic, and social contexts. Proslavery Virginians recognized that the longevity of slavery required situating slavery as the basis for republican government, a reconceptualization that sought to inextricably bind the health and future of two institutions. Slavery could also replace the increasingly useless and archaic freehold as a guarantor of republican virtue and liberty. The frank discussions concerning slavery following Nat Turner's rebellion necessitated a stronger defense of the master-slave relationship and the rights of private property in slaves. At the core of all three defenses rested a recognition that slavery's future depended on nonslaveholders, including those in the Northwest. By extending the advantages of slavery beyond the plantation and into every household, business, and polling station, Leigh, Dew, and Upshur illustrated the institution's centrality to all white men. Though northwesterners owned fewer slaves than other regions in Virginia, they enjoyed identical privileges and benefits offered to all white Virginians. The often volatile economic context that characterized industrialization in the Northwest might jeopardize a white man's employment, but he could rest assured that he would never fall below the level of an African American. This

\footnotetext{
${ }^{88}$ Upshur, "Domestic Slavery," 679.
} 
hardening of the color line reflected the increasingly popular and powerful southern axiom that slavery for African Americans generated and protected liberty and independence for white men.

Over the proceeding decades, northwesterners internalized and championed these political ideas, becoming vocal pro-democratic and proslavery Virginians. The entrenchment of the two-party system in Virginia throughout the 1830s and 1840s assisted this development by inaugurating a raucous style of popular politics that elevated the image of and vested political power in the common man. In the slaveholding South, the two-party system pitted politicians and partisans against each another in a political struggle over which party provided the strongest defense for slavery ${ }^{89}$ This brand of politics invited participation among all white Virginians, including those in the Northwest who remained disenfranchised. The political arena of northwestern Virginia mirrored other developments across the South, but the region's proximity to northern states also shaped residents' expectations of their state government. The constant interaction with residents of Ohio and Pennsylvania, two states that offered greater political representation to white citizens, intensified northwesterners' demands for political equality. Within these demands, though, northwesterners offered their pledges of fealty to state and concessions to slaveholders, a clear reflection that the rhetorical effort begun by Leigh, Dew, and Upshur was paying dividends. The path toward democratic reform would be colored distinctively by slavery.

The entrenchment of the two-party system across the state represented one of the critical developments that lent credence to the ideas put forth by Leigh, Dew, and Upshur. As Michael Holt has demonstrated, the two-party system operated effectively on national and state levels because it allowed extensive competition along a broad spectrum of issues. Political parties took

\footnotetext{
${ }^{89}$ William J. Cooper, Jr., The South and the Politics of Slavery, 1828-1856 (Baton Rouge: Louisiana State University Press, 1978).
} 
opposing sides on pertinent political, economic, and social issues, and offered to voters what each party considered the proper means of achieving and maintaining a healthy republican government. A stark demarcation between the two organizations emerged through this process. ${ }^{90}$ The two dominant parties during the 1830s and 1840s, the Whigs and Democrats, possessed all the trappings of modern political parties, including ideologically oriented platforms, caucuses and nominating committees, partisan news outlets, and candidates canvassing the region.

The Northwest was no exception to this development. The proliferation of partisan newspapers, competitive local elections, and the sights and sounds of campaign season clearly illustrated that northwesterners participated in one the key political movements of the era. A supporter of Waitman T. Willey instructed him to "mount your horse and scower the County maik Stump Speaches etc." if he desired to win election to the House of Delegates. Willey, though a prominent and respected Whig in Monongalia, still faced intense competition in a district that heavily favored Democrats. ${ }^{91}$ Democrats also performed well in counties along the Ohio River, southwestern Virginia, and in areas generally undisturbed by the Market Revolution. Whigs garnered the majority of their support in burgeoning manufacturing towns, including Wheeling and Charleston, and in counties favorable to internal improvements. ${ }^{92}$ Both parties worked to mobilize white residents to the polls during elections, hopeful that their message (and perhaps a few alcoholic beverages) would convince residents to vote for their respective candidate. ${ }^{93}$

\footnotetext{
${ }^{90}$ Michael F. Holt, The Political Crisis of the 1850s (New York: Wiley, 1978).

${ }^{91}$ James Evans to W.T. Willey, 3 March 1840, Charles H. Ambler Collection, A\&M 122, Box 10, Folder 2, item 54, WVRHC.

${ }^{92}$ Foulds, "Enemies of the State," 59-60.

${ }^{93}$ Shade, Democratizing the Old Dominion. One contemporary Whig newspaper chastised residents who continued to become "beastly drunk" on hard cider, a favorite "locofoco electioneering" tactic designed to persuade undecided voters to support the Democratic Party. Fairmont Pioneer, July 23, 1843, 3. The practice of "treating" continued well into the 1850s. One Morgantown resident criticized a politician who he saw "treating with cigars and drinking"
} 
The two-party system in Virginia proved crucial for creating a political détente between western and eastern Virginians, specifically on the issue of slavery. As William Cooper has shown, both Whigs and Democrats portrayed their organizations and ideologies as "safe" on the issue of slavery while accusing the opposition of advocating subversive and inimical principles that imperiled the peculiar institution. The "politics of slavery," according to Cooper, mitigated conflict between nonslaveholders and slaveholders and ultimately defined and shaped southern politics before the Civil War. ${ }^{94}$ While Cooper focuses on regions and states across the South with large enslaved populations, this dynamic unfolded along the peripheries of the South, too, including northwestern Virginia. When vetting candidates, some residents supported those who hailed from southern soil. Morgantown resident Thomas P. Ray faced a quandary in the months leading up to the 1836 presidential election as he preferred neither Democrat Martin Van Buren nor Whig Hugh L. White. But White was a Tennessean. "I will choose the southern one," he concluded, confident that White's southern credentials implied his fealty toward the institution. Van Buren, a New Yorker, simply could not be trusted to protect slavery. ${ }^{95}$

The "politics of slavery" were clearly manifest in partisan newspapers, as Whigs and Democrats accused the other of being "unsafe" on the issue of slavery. "It has been for some time drummed in our ears," a Wheeling Whig newspaper lamented, "that the whigs are abolitionists, and that the only safety of the South is in re-electing Mr. Van Buren." Supposedly, the editor complained, only Democrats could be trusted on the sacrosanct issue of slavery. ${ }^{96}$ Whig partisans often denounced Democrats as radical "Loco Foco Abolitionists" who employed

\footnotetext{
with residents following his nomination. John Huddeson to Fletcher Brock, April 2, 1855, Fletcher Brock Collection, A\&M 2869, WVRHC.

${ }^{94}$ Cooper, The South and the Politics of Slavery, xi.

95 Thomas P. Ray to W.T. Willey, 9 February 1835, Charles H. Ambler Collection, A\&M 122, Box 10, Folder 1, item 4-9, WVRHC.

${ }^{96}$ Western Virginia Times \& Advertiser, February 20, 1840, 1.
} 
unscrupulous tactics and spread false rumors in an effort to debase Whigs' slavery credentials. One Whig newspaper returned such a charge, arguing that Democrats' attempts to brand Whigs as unsafe on the issue of slavery represented desperate and manipulative attempts to destabilize the country, a goal Democrats shared with northern abolitionists. ${ }^{97}$ Even the nomination of a southern Whig for president failed to silence some Democrats' accusations. Supporters of Virginian William Henry Harrison during the 1840 Presidential election denied the general's support of abolitionism, arguing that no politician "has gone farther, in his opposition to the schemes of the fanatics." 98

When not denouncing their supposedly abolitionist foes, Democrats burnished their candidates' proslavery credentials. Democrats exalted the "patriotism and political integrity" of their candidates who advocated sound "Democratic doctrines," including the protection of slavery against federal encroachment. ${ }^{99}$ A group of Morgantown residents echoed such sentiments during a Fourth of July celebration. Whigs' disdain for Democratic candidates, one reveler proclaimed, resulted from Democrats' "steadfast principles," which included a marked vigilance on the issue of slavery. ${ }^{100}$ Indeed, Democrats often found greater success in wielding the issue of slavery against their opponents. A Brooke County newspaper editor, reflecting on the conflicts between Whigs and Democrats, admitted that Democrats possessed a "pronounced predilection for proslavery ideas." Democrats' political dominance in the county "for a generation or more" reflected a widespread acceptance of the party and its proslavery ideas. ${ }^{101}$ Even Whigs begrudgingly admitted that Democrats often utilized the issue of slavery more

\footnotetext{
${ }^{97}$ Western Virginia Times \& Advertiser, December 28, 1839, 2.

${ }^{98}$ Parkersburg Gazette, August 6, 1840, Peter G. Van Winkle Collection, A\&M 136, Box 2, WVRHC.

${ }^{99}$ Marshall Beacon [Moundsville], March 25, 1840, 1.

${ }^{100}$ [Parkersburg Gazette?], March 2, 1839, Monongalia County Scrapbook, A\&M 1007, WVRHC.

101 John G. Jacobs, Brooke County, being a Record of Prominent Events, Occurring in Brooke County, W.VA., from the Settlement of the Country, until January 1, 1882 (Wellsburg: Herald Office, 1882), 156-157.
} 
effectively. One national Whig politician lamented that despite Zachary Taylor's election in the 1848 presidential election, Virginians continued to support Democratic candidates, including Lewis Cass. "Old Virginia is still wedded to her idols," he bemoaned, a clear indication of Democrats' superior ability in this election to use the "idol" of slavery to their advantage. ${ }^{102}$

The inclusivity and democratic participation generated by the "politics of slavery" and the two-party system in general represented an important characteristic that mobilized slaveholders and nonslaveholders, freeholders and nonfreeholders, into the political sphere. Here, though they possessed different socioeconomic backgrounds or enjoyed different positions of status in the community, their racial status subsumed these differences. Meetings that often numbered in the thousands became commonplace across the Northwest, bringing residents from across the region into Wheeling, Morgantown, Bridgeport, and other towns. Wheeling resident Peter Garnall, in a letter to his nephew in Florida, remarked at the "excitement" surrounding the upcoming presidential election later that fall. Approximately "three thousand" Whigs convened north of Wheeling while a Democratic meeting equal in number gathered in Bridgeport. Garnall, a Whig, noted that the "overwhelming majority of men women and children" supported the Whig candidate, William Henry Harrison. ${ }^{103}$

Partisans during these political meetings sought to discredit their opponent's platform while burnishing their own, in the hopes of drawing new adherents. Nearly twenty-thousand Whigs gathered in Wheeling to hear political speeches and witness the operation of a nail machine and handle instruments used in glass manufacturing and in the iron foundry. The enterprising spirit exhibited in these three professions represented a marked contrast from

\footnotetext{
${ }^{102}$ M. Criss to Gideon D. Camden, 15 November 1848, Gideon D. Camden Collection, A\&M 1199, Box 2, Folder April 1848 to April 1849, WVRHC.

${ }^{103}$ Peter Garnall to Mordecai Garnall, 9 June 1840, Peter Garnall Collection, A\&M 2543, WVRHC.
} 
Democrats who adhered to traditional agricultural pursuits. ${ }^{104}$ An advertisement for a Whig meeting in Morgantown invited “ALL...WHIG FRIENDS, AND EVERY BODY ELSE” who disapproved of the spoils system used by Andrew Jackson and Martin Van Buren. ${ }^{105}$ Conversely, a Democratic meeting in Morgantown hoped that the "Democrats of the Mountains" would come out in full force to support the Democracy and rescue Virginia from Whig politicians. Democrats welcomed their own members and disenchanted Whigs, too, including those in Maryland, Pennsylvania, and Ohio. ${ }^{106}$

The style of interparty disagreement between Whigs and Democrats manifest during these meetings carried over into the state legislature. Delegates, like their constituents, debated the National Bank, currency, tariffs, internal improvements, the spoils system, and the scope of presidential power supplied fodder for both political parties. Roll-call votes of Whigs and Democrats on many economic issues, such as banking and currency revealed a high level of disagreement between 1835 and 1843. In other economic areas, such as granting corporate charters, Virginia fell in line with other states. ${ }^{107}$ The composition of the state legislature likewise reflected this intense party debates. From 1838 to 1841, for example, Whigs possessed a slight numerical advantage over Democrats, often registering somewhere between one and five percent. ${ }^{108}$ This intense partisan conflict ensured that political parties continued to court voters, a process that helped mobilize more northwesterners into the political sphere. ${ }^{109}$

\footnotetext{
${ }^{104}$ Marshall Beacon, September 14, 1844, 2.

105 Democratic Republican [Morgantown], September 25, 1840, 3.

${ }^{106}$ Democratic Republican [Morgantown], October 21, 1852, 2.

${ }^{107}$ This argument builds off figures provided in Table 4 "Indexes of Interparty Disagreement on Roll-Call Votes on Economic Issues in Selected State Legislatures, 1835-1844," in Michael F. Holt, The Rise and Fall of the American Whig Party: Jacksonian Politics and the Onset of the Civil War (Oxford: Oxford University Press, 1999), $72-73$.

108 These figures are provided in Table 6 "Whig Share of the Seats Won in the Lower House of the Legislature in All States but South Carolina, 1836-1843," in Holt, American Whig Party, 75.

109 Jeffrey L. Pasley, "Party Politics, Citizenship, and Collective Action in Nineteenth-Century America: A

Response to Stuart Blumin and Michael Schudson," The Communication Review, 4, no.1 (2000): 39-54.
} 
While the two-party system encouraged broad participation and intense interparty disagreement, this system also reminded Virginians of those who remained disenfranchised due to constitutional requirements. Partisan meetings in the Northwest often invited fellow Whigs or Democrats from Pennsylvania and Ohio, too, two states that offered far greater political representation for its residents than Virginia. ${ }^{110}$ Indeed, while the state's political parties often fostered sectional harmony on national issues, the lack of political representation for many western Virginians brought some Whigs and Democrats together on the issue of constitutional reform. ${ }^{111}$ As Peter G. Van Winkle suggested, Virginians, regardless of party affiliation, should demand with one voice "an adequate remedy for the evils we deplore." Those "evils" often arose from a constitution Van Winkle and other northwesterners considered broken. ${ }^{112}$

Virginians hopeful for constitutional reform, though, confronted opposition from eastern elites. The 1830 Constitution required the state legislature to review census data and reapportion representation accordingly, but Tidewater and Piedmont planter-politicians in the General Assembly refused to follow through. ${ }^{113}$ The returns from the 1840 U.S. Census revealed the continuation of demographic trends that began decades earlier. The white population west of the Blue Ridge Mountains registered more than that east of the mountains, further validating western Virginians' claims that a minority wielded power over the majority. ${ }^{114}$ Moreover, though the state's total slave population decreased during the previous decade, this decline occurred

\footnotetext{
${ }^{110}$ For example, see Harrison Whig [Clarksburg], August 27, 1840, 4.

${ }^{111}$ For example, see Kanawha Banner [Charleston], May 8, 1834, 2 and Lewisburg Alleghanian, March 7, $1834,3$.

112 Peter G. Van Winkle to Charles P. Bailey, 12 April 1842, Peter G. Van Winkle Collection, A\&M 18, WVRHC. For an opposing interpretation of the role of party politics in fostering constitutional reform, see Lewis Summers to George Summers, 28 February 1842, Lewis and George W. Summers Papers, Box 1, Folder 2, WVRHC. Lewis Summers argued that "the delusive theories of party politics" distracted residents from pursuing constitutional reforms. Party politics in Summers' home of Putnam County, though, differed from that in the Northwest. The Northwest's close proximity to Ohio and Pennsylvania meant the intermingling of Virginians with those of northern, nonslaveholding states that offered greater political representation to its white residents.

${ }^{113}$ Proceedings and Debate, 705.

${ }^{114}$ Shade, Democratizing the Old Dominion, 22 and Ambler, Sectionalism in Virginia, 251.
} 
primarily on the western side of the Alleghenies. Numerous counties in the Tidewater, Piedmont, and Shenandoah Valley witnessed an increase in their slave populations. ${ }^{115}$ These demographic trends demonstrated to one Wheeling resident that northwesterners have been "basely and heartlessly cheated out of our just rights by a minority."116 This "tyrannical and oppressive" form of government, a Lewis County resident declared, required immediate reform to stop the eastern minority from continuing to wield "ruthless" power over the majority. ${ }^{117}$ The demands and justifications articulated by northwestern residents for a new constitution in the 1840 s generally mirrored those expressed prior to the $1829-1830$ Constitutional Convention. Residents' focused on obtaining universal male suffrage, addressing malapportionment in the state legislature, reforming the county court system, allowing for the public election of government officials, and creating a state-supported public education system. Residents' justifications for these reforms likewise echoed those leading up to the previous constitutional convention. Some residents harkened back to the memory of the American Revolution, where, northwesterners maintained, ordinary men had demonstrated their political fitness and boldly sacrificed their lives in the quest for a republican government. At a constitutional reform meeting in Gilmer County, residents assailed the current system used to calculate representation, the "mixed basis." This "arbitrary and unequal" system of apportionment was "wholly irreconcilable with our great revolutionary struggle, which made us

\footnotetext{
115 The aggregate numbers for 1830 and 1840 were 469,757 and 449,087, respectively, a difference of roughly twenty-thousand. Across the Northwest, most counties witnessed a considerable drop in their slave population. For example, the number of slaves in Brooke County decreased from 228 to 91 while Ohio County witnessed a decline from 360 to 212. Such figures were representative for the entire region. University of Virginia Geospatial and Statistical Data Center: Historical Census Browser [http://mapserver.lib.virginia.edu/php/state.php] [accessed on 19 March 2015]

${ }_{116}$ Western Virginia Times \& Advertiser, November 17, 1841, 2.

117 Weston Sentinel, July 20, 1849, 2.
} 
free and independent." White men, not African American slaves, deserved political representation in accordance with the memory of the American Revolution. ${ }^{118}$

Residents' use of the memory of the American Revolution to justify a new constitution dovetailed with the "natural rights" argument. Ordinary men in 1776 clearly illustrated that the possession of property, whether landed or human, was unnecessary to determine one's political fitness. Rather, all white men possessed the natural right to self-government. At a reform meeting held in Wood County, residents professed their belief in the doctrine that "every citizen" should be entitled to "absolute and practical equality," regarding it as "an original or fundamental right."119 In a Fourth of July Speech in Wood County, Peter G. Van Winkle supported the "great principle of equality," denounced the "false distinctions" created by the constitution, and "profess[ed] my faith in my fellow man." "[T]he people," he maintained, "are the safest depositories of all governmental power."120 The right of suffrage represented one of the "natural rights of man," Wheeling newspaper editor J.E. Wharton asserted. Other states correctly recognized that "a man holds suffrage as an inherent right vested in him by his Creator" while "the demagogue with a few acres of ground" could practically "manufacture" a class of citizens beholden to him, not to the state's interests. ${ }^{121}$ By reforming the constitution, Virginians would ensure the manifestation of Providence's design and promote a fair and equitable political system free from manipulation.

The spirit and progress of Jacksonian Democracy over the past decade validated northwesterners" arguments that "the people" could be trusted in their exercise of political

\footnotetext{
${ }^{118}$ Weston Sentinel, October 30, 1846, 2.

${ }_{119}$ Parkersburg Gazette, December 25, 1845, 3.

${ }^{120}$ Fourth of July Oration, Wood County, July 4, 1847, Peter G. Van Winkle Collection, A\&M 136, Box 1, WVRHC.

${ }^{121}$ Western Virginia Times \& Advertiser, November 17, 1841, 2.
} 
power. "Old Virginians," complained a James E. Wharton of Wheeling, "do not feel that men are now able to govern themselves." "[B]ut the people feel that they are able," he stated confidently, and deserved the opportunity to demonstrate their political fitness. ${ }^{122}$ The current "age requires no less" than a thorough constitutional revision, one Parkersburg newspaper explained, an age where all white men enjoyed the prerogatives of citizenship regardless of wealth or social status. ${ }^{123}$ The spirit of Jacksonian Democracy that had empowered "the people" had also inspired southerners to reshape their state constitutions. This reform occurred without endangering slaveholders' rights, encouraging some northwesterners to look to these southern states for guidance. One northwestern politician advised "following the example of Kentucky and making even the judges elective by the people." ${ }^{124}$ The popular election of judges would help remove the traces of nepotism and corruption that plagued the county court system. Peter G. Van Winkle entrusted his fellow northwesterners to "do what is safely done by the people of other states," specifically the "preservation or...exercise" of political power. ${ }^{125}$ Slaveholding states that had embraced democratic principles failed to devolve into anarchy and slavery remained secured, refuting many easterners' assertions about democracy's inherent threat to private property. ${ }^{126}$

The change in social sensibilities manifested in Jacksonian Democracy reflected the changing economic context, too. In the Northwest, the growth of glass works, nail

\footnotetext{
122 Western Virginia Times \& Advertiser, December 1, 1841, 2.

${ }^{123}$ Parkersburg Gazette and Western Virginia Courier, May 19, 1849, 2.

${ }^{124}$ M.H. Johnson to Gideon D. Camden, 7 December 1849, Gideon D. Camden Collection, A\&M 1199, Box 2, Folder May 1849 to March 1850, WVRHC.

${ }^{125}$ Fourth of July Oration, Wood County, July 4, 1847, Peter G. Van Winkle Collection, A\&M 136, Box 1, WVRHC.

${ }^{126}$ For example, see Views of the Constitution of Virginia, contained in the essay of "One of the People;" and in the Letters of Messrs. Robinson, Macfarland, Morson and Patton. In reply to a Communication from many citizens of the Richmond District (Richmond: Colin, Baptist and Nowlan, 1850), 46-47, 57, 63. [hereafter cited as Views of the Constitution of Virginia]
} 
manufacturers, and iron foundries often meant the movement of men and their families from the countryside into the towns of Wheeling, Wellsburg, and their surrounding environs. But as these men moved into the cities, their opportunity to obtain a freehold—and illustrate a permanent attachment to the community in accordance with republican ideology_diminished. Though these men labored and contributed to the state's economic health, they lacked political representation, an absurdity in the minds of many residents. "[P] roperty cannot be made the evidence of a man's permanent interest with and attachment to the community," a Wheeling newspaper proclaimed. ${ }^{127}$ Wheeling, the locus of much of this dynamic economic growth, witnessed an increase in demands for political representation as its industrial labor class matured during this period. In nearby Wood County, residents declared in a reform meeting that "the possession of property" bestowed neither increased political power to its owner nor should it be used to determine political representation. ${ }^{128}$ One Weston resident believed that the "class...of nonfreeholders" who paid taxes or served in the militia demonstrated a "permanent common interest with, and attachment to, the State." ${ }^{129}$ As the region's economy developed along a different trajectory than other areas in Virginia, its residents would continue to feel the burden of a state constitution that, though partially reformed, needed to reflect changing economic and social contexts.

Historians exploring sectional tension in Virginia have accurately recognized other longstanding grievances and demands articulated by western Virginians. Alongside important political and constitutional reforms, historians observe that western Virginians believed that a democratized state constitution would facilitate the creation of a public school system and lead to

\footnotetext{
${ }^{127}$ Western Virginia Times \& Advertiser, November 17, 1841, 2.

${ }^{128}$ Parkersburg Gazette, December 25, 1845, 3.

${ }^{129}$ Weston Sentinel, July 20, 1849, 2.
} 
greater state investment in internal improvements in western Virginia. Such sentiments were widespread throughout the Northwest in the 1830s and 1840s. Northwesterners blamed their failure to achieve political, economic, and social reforms on obdurate eastern slaveholders and politicians. These men, many northwesterners believed, privileged their chattel over white equality and sought to consolidate political power in an effort to arrest the development of the largely nonslaveholding Northwest. Subsequent historians have interpreted this evidence to explain Virginia's eventual dismemberment along clear, sectional lines. Indeed, the frustration exhibited by western Virginians during the 1830s and later during the secession crisis appears to reaffirm this interpretation. ${ }^{130}$

However, extant evidence also reveals an important, complementary narrative. Throughout the 1840s, northwesterners expressed their continued fealty toward Virginia, their hopes for greater sectional harmony, and a firm belief that slaveholders deserved extra safeguards to protect their chattel from external threats. This evidence, overlooked or dismissed by previous historians, offers an interpretation of the state undergoing a "détente" through slavery. Indeed, alongside northwesterners' demands for constitutional reforms were offers to support slaveholders' pursuit of greater political protection over their chattel. Northwesterners remained hopeful that these public pronouncements would demonstrate their fealty toward the state's foremost institution and that the inclusion of large numbers of nonslaveholders would strengthen, not endanger, slavery. Further, these public pronouncements revealed

\footnotetext{
${ }^{130}$ Antebellum Virginia historiography often focuses on the growing sectional division in the state, portraying the eastern-dominated state legislature's refusal to acquiesce to western demands as markers on the road to the eventual dismemberment of the state. For example, see Ambler, Sectionalism in Virginia; Freehling, Drift toward Dissolution; Freehling, Road to Disunion: Secessionists at Bay; Link, Roots of Secession, 11-15; Charles Ambler, "The Clarksburg Educational Convention of September 8-9, 1841," West Virginia History 5, no. 1 (October 1943): 5-54; Thomas C. Hunt, "Sectionalism, Slavery, and Schooling in Antebellum Virginia," West Virginia History, 46, no. 1-4 (1985-1986): 125-136; and, Foulds, "Enemies of the State," 47-50, 59.
} 
northwesterners' support of the ideological reconceptualization of republican thought initiated by Leigh, Dew, and Upshur a decade earlier. Rather than a stumbling block, slavery would become the medium through which democratic and constitutional reform would be achieved.

In October 1845, residents of Lewis County and nearby Harrison County gathered at the local courthouse to discuss and debate constitutional reform. Residents approved the passage of six resolutions that contained many of the common political and constitutional grievances, including the need to inaugurate the "white basis" in the state legislature and the rightful power of majoritarian rule. After the six resolutions had been read aloud, Judge Edwin S. Duncan offered his interpretation of the sectional discord affecting Virginia. While Duncan castigated the "unjust discrimination against the West" by eastern Virginians, he reminded those gathered of their past fealty and continued responsibility to the state and its institutions. "[W]ith what care they had watched over the slave interest, peculiar to the East," he proclaimed. The "obedience and loyalty" northwestern Virginians had exhibited over the past years evinced their support for slavery and that they would protect, not threaten, the institution. Indeed, the "security" desired by eastern slaveholders would occur if they extended "justice" to western Virginians. By the meeting's end, residents unanimously adopted another resolution, stating that northwesterners remained "utterly opposed to a dismemberment of the State for any purpose whatever....[W]e will not separate from the East, and the East will not separate from us." Rather than actively pursue a division of the state or attack slaveholders or slavery, these northwestern residents professed their unwavering support for the state and offered extra protections for slaveholders. Democratic reform would not harm slavery, residents concluded; it would protect and strengthen it. ${ }^{131}$

${ }^{131}$ Parkersburg Gazette, October 23, 1845, 1. 
Northwestern residents and politicians who supported the belief that political reform and greater security for slavery could occur simultaneously also demanded that the two elements needed to remain in equilibrium. Reform must not threaten private property, while the need to protect slavery could not prevent white equality. In a letter to constituents, four northwestern politicians maintained their support for the "white basis" and refused to concede to the "mixed basis" on any new constitution. While slaveholders were "entitled to efficient protection" on their property, that protection could not supersede white northwesterners" "social and political rights."132 One contributor to the Wellsburg Weekly Herald supported an ad valorem tax that would operate equally across the state, an important attribute that would not "oppress the tax payer, or his peculiar property." Northwestern Virginians "unanimously" supported this plan as it would "make Virginia 'one and indivisible.",133 Support for policies and safeguards favorable to slavery and slaveholders extended into the Shenandoah Valley, too. "We would not...refuse adequate protection in the shape of guarantees, to property, if the East desire it," one Shepherdstown newspaper argued. This "compromise" would "not injure us" but rather promote sectional harmony. ${ }^{134}$ "We are willing to see it [slavery] properly surrounded by guards against improvident legislation, and excessive taxation," residents admitted, but not "as an element in the distribution of political power."135 Protection for slavery could not supersede political representation for whites but rather both should help form a healthier and more durable body politic.

These public pronouncements extolling the need for political representation and protection for slaveholders accompanied expressions of fealty toward the state. These

\footnotetext{
132 Parkersburg Gazette and Western Virginia Courier, November 16, 1850, 2.

${ }^{133}$ Wellsburg Weekly Herald, February 22, 1850, 2.

134 Shepherdstown Register, July 30, 1850, 2.

135 Shepherdstown Register, August 13, 1850, 2.
} 
expressions served to reaffirm northwesterners' identity as Virginians and as loyal supporters to the state's institutions. In a reform meeting held at the Wheeling courthouse, residents acknowledged the political evils produced by the constitution and the obduracy exhibited by eastern politicians. Still, residents rejected discussion of dividing the state. "We are opposed to anything like drawing invidious lines of distinction" that could precipitate dismemberment, residents maintained. ${ }^{136}$ In Lewis County, the newspaper editor confessed that many residents "prefer a division of the State to any other mode of redress." These same residents, though, prayed that such an occurrence "may never come" and looked longingly for "chords of common interest" that would bind all Virginians. ${ }^{137}$ Parkersburg residents professed that despite the lack of political representation, they nevertheless felt "deeply attached to this Ancient Commonwealth" and "counted [themselves] among her children." Achieving political equality, not a division of the state, represented their primary goal. ${ }^{138}$ Ritchie County residents expressed similar sentiments. They "hope[d] that our brothers of Eastern Virginia" would act with greater fidelity to western Virginians as they constituted "children of the same good old Commonwealth." ${ }^{139}$ Talk of division creeped into some discussions concerning constitutional reform, but residents often softened that threat by pledging fealty to the state or wielded the specter of disunion to communicate the magnitude of the political injustice northwesterners experienced. Northwesterners considered themselves Virginians first and foremost.

Opponents to this thinking existed in the region, though. These residents maintained that the presence of slavery prohibited true and lasting democratic reform, and that such reform could only succeed once the state removed its slave population. Such voices, however, remained

\footnotetext{
${ }^{136}$ Wheeling Times, reprinted in Parkersburg Gazette, July 14, 1842, 1.

${ }^{137}$ Weston Sentinel, February 25, 1848, 2.

${ }_{138}$ Parkersburg Gazette, December 25, 1845, 3.

${ }^{139}$ Parkersburg Gazette, January 19, 1848, 2.
} 
isolated and marginalized from accepted and established political thought. In Preston County, newspaper editor F.B. Woodward argued that slavery represented "an affliction, a plague, a cankering, itching cancer" in need of immediate removal. Only the removal of slaves from the state could assure pure and enduring democratic reform. ${ }^{140}$ Anson Berkshire in Ohio County shared such sentiments. His newspaper, The Crisis, maintained that some form of emancipation would inaugurate political and social freedom for white men. "The deep-bedded social evil of Slavery" demands "decisive, unflinching, [and] uncompromising" action, Berkshire averred. How could a state singularly devoted to slavery "constitute a republican government?"141 The impassioned pleas from both Berkshire and Woodward, though, represented isolated and radical voices on the issue of slavery. While some northwesterners believed that slavery precluded constitutional and democratic reform, few argued that removing slavery was feasible or practical. Rather, the majority of northwesterners who demanded political reform understood that it would only occur with concomitant pledges to protect slaveholders' property.

Residents' pursuit of another constitutional convention acquired momentum throughout the 1840s. National and international discussions concerning slavery and slaveholders' rights impressed upon some Virginians about the need to resolve domestic disputes. ${ }^{142}$ Northwesterners' continuing pledges of fealty to the state and support for slavery aided such thoughts. Even some eastern Virginians appeared supportive of a new constitutional convention. "The press and people of Eastern Virginia," a Parkersburg newspaper reported, "appear to have undergone.... a total revolution in sentiment with reference to...a constitutional convention." Such advocacy reflected an awareness on the part of easterners of the "odious" features of the

\footnotetext{
${ }^{140}$ Fellowsville Democrat, December 22, 1848, 2.

${ }^{141}$ The Crisis, April 29, 1848, 3.

142 Foulds, "Enemies of the State," 75.
} 
constitution that hampered the entire state, not solely the West. ${ }^{143}$ Indeed, many northwestern legislators heard that a "large number of the Eastern members are in favor of a Convention."144 Still, numerous eastern Virginian planters and politicians remained unimpressed by northwesterners' pronouncements or that constitutional reform would preserve slavery or aid the Commonwealth. In two consecutive sessions in the early 1840 s, the eastern-dominated state senate defeated proposals to call for a convention, and then promptly ignored a similar request by the governor a few years later. ${ }^{145}$ Richmond lawyer Arthur Alexander Morson argued that the "mixed basis" was "essential to the protection of eastern Virginia" as western Virginians owned few slaves and had displayed hostile attitudes to slavery in past political and constitutional conflicts. Constitutional and democratic reform would place eastern Virginia and its peculiar property in a "prostrate" position "at the foot of western Virginia." Morson denied the feasibility and efficacy of democratic reform in a slaveholding state. ${ }^{146}$ Barbour County attorney John Carlile lamented that northwesterners will "have to wring from the east" any acknowledgement of political equality or a call for a constitutional convention. ${ }^{147}$ Political reform, even if a constitutional convention could be achieved, was far from certain.

Even some northwesterners expressed misgivings about a convention. Though the "white basis" received widespread support in the Northwest and supporters declared that "freemen will never tolerate" any other plan, other westerners supported the "mixed basis."148 John Carlile noted that "Valley men and Trans-Allegheny men... are opposed" to the "white basis," tracing

\footnotetext{
${ }^{143}$ Parkersburg Gazette and Western Virginia Courier, December 15, 1849, 2.

${ }^{144}$ M.H. Johnson to Gideon D. Camden, 1849 December 7, Gideon D. Camden Collection, A\&M 1199, Box 2, Folder May 1849 to March 1850, WVRHC.

145 Wilentz, Rise of American Democracy, 588.

${ }^{146}$ Views of the Constitution of Virginia, 57. [emphasis in original]

${ }^{147}$ John Carlile to Jonatham M. Bennett, 31 January 1850, Jonathan M. Bennett Collection, A\&M 32, Box 6, item 1590, WVRHC.

${ }^{148}$ Western Virginia Standard [Morgantown], October 3, 1846, 2.
} 
this opposition to residents who "are jealous of the rapid growth of the North West." "We should not bestow all our censure to the east when we differ among ourselves," he confessed. ${ }^{149}$ Other northwesterners appeared willing to concede to the "mixed basis" if it convinced eastern Virginians to convene a constitutional convention. "Some our members think we ought to be willing to compromise [on] the matter," one northwestern politician reported. ${ }^{150}$ Other western Virginians worried about the breadth and depth of reform. Morgantown merchant Henry Dering admitted that "we need reform," but wondered if reformers would know "where to stop." Democratic reform could devolve into a "hazardous experiment" that could graft the "wildest schemes" imaginable onto the constitution with unknown (and possibly dangerous) consequences. ${ }^{151}$ Further south, Lewis Summers prayed for reform "but without running into a Shay's or Dorr rebellion." Once reformers began altering the state's political foundations, would they retain proper safeguards to protect private property and restrain radical political elements? ${ }^{152}$

The divisions that hampered reformers' aspirations in 1830 emerged again two decades later, revealing once again a divided Northwest and the uneven and uncertain progression of democratic principles across the slaveholding South and the nation. Ultimately reformers differed over their interpretation of a democratic Virginia. Would property qualifications for voting be removed or simply lessened? How would the General Assembly be apportioned? How would slavery shape the state's political structures? What power should be accorded to

\footnotetext{
${ }^{149}$ John Carlile to Jonathan M. Bennett, 23 March 1848, Jonathan M. Bennett Collection, A\&M 32, Box 5, item 1153, WVRHC.

${ }^{150}$ M.H. Johnson to Gideon D. Camden, 7 December 1849, Gideon D. Camden Collection, A\&M 1199, Box 2, Folder May 1849 to March 1850, WVRHC.

${ }^{151}$ Henry Dering to Waitman T. Willey, 23 October 1850, Charles H. Ambler Collection, A\&M 122, Box 10, Folder 3, item 129, WVRHC.

${ }^{152}$ Lewis Summers to George Summers, 7 June 1842, Lewis and George W. Summers Collection, A\&M 1791, Box 1, Folder 2, WVRHC.
} 
private property and its owners in a democratic polity? Would an expanded electorate comprised mostly of nonslaveholders weaken or strengthen the government? Answers to these questions would dominate any constitutional convention.

In 1849, the eastern-dominated state legislature acquiesced to western demands and passed a bill that called for a constitutional convention to be convened on the "mixed basis." 153 While eastern Virginians conceded to call a convention, it would be assembled on their terms, including granting a generous majority of fifteen delegates to their section. The popular referendum that called for a convention on the mixed basis garnered statewide approval, with comfortable majorities in the Tidewater and Piedmont and strong opposition in the western counties. ${ }^{154}$ And even though northwesterners avowed they "cannot submit" to this plan and considered it a "dishonor," they consented, believing that any convention provided an opportunity to achieve some level of constitutional reform. ${ }^{155}$ In the fall of 1850 , northwestern delegates trekked across the mountains to Richmond in search of political equality for their constituents, an endeavor far from guaranteed.

Twenty years after the last constitutional convention, Virginians once again assembled in Richmond and in taverns, churches, meeting houses, and courthouses across the state to debate constitutional and political reform. Though northwesterners expressed frustration and disappointment over the ratification of the 1830 Constitution, these feelings quickly faded as residents considered the benefits of the new constitution and the drawbacks of hasty, reckless

\footnotetext{
${ }^{153}$ Many Virginians also believed that eastern legislators' capitulation to western demands signaled their hope to preclude some of the more democratic reforms. Marion County delegate James Neeson confirmed this belief. Neeson stated that an eastern delegate admitted that he and "many others" supported a call for a convention "in order to prevent the possibility of a transfer from Eastern to Western Virginia of the political preponderance of the State." Neeson estimated that "nine-tenth" of easterners acted in similar fashion. Register of the Debates and Proceedings of the Virginia Reform Convention (Richmond: R.H. Gallaher, 1851), 468. [hereafter cited as Virginia Reform Convention]

${ }^{154}$ Foulds, "Enemy of the State," 76.

${ }^{155}$ Parkersburg Gazette and Western Virginia Courier, February 23, 1850, 2.
} 
actions. The entrenchment and growth of the two-party system in the region welcomed broad participation among voters and non-voters, allowing all men an opportunity to engage in debates, meetings, and party functions. The conflicts between Whigs and Democrats often centered on which party best protected slavery and, with it, white men's political independence. Through these battles, residents understood and accepted the southern axiom that slavery for African Americans produced political equality for white men. This southern axiom, refined and promulgated by Leigh, Dew, and Upshur, would become the defining characteristic of Virginia politics through the U.S. Civil War.

Residents" engagement in the "politics of slavery" during this twenty year period reflected their growing support for the state and slaveholders' rights. Rather than actively seeking a division of the state or attacking slaveholders or slavery, residents expressed fealty to the state, support for extra safeguards for slaveholders, and a belief that democratic and constitutional reform could be achieved through the institution of slavery. Indeed, numerous northwesterners believed that greater protection for slavery could be achieved through democratic reform, a dynamic that had unfolded with great success in other southern slaveholding states. Opponents in the region denied any compatibility between democracy and slavery, but these few voices remained on the periphery of the Northwest's political culture. Democracy and slavery could sustain and strengthen each other, residents believed, ensuring a durable and healthy republican government that would diminish sectional tension. But achieving democratic and constitutional reform in 1850-1851 meant persuading eastern legislators and slaveholders that nonslaveholders would support, not threaten, their peculiar property. Many easterners, aware of the growth and assertiveness of antislavery groups in national politics, balked at such suggestions. The future of the Commonwealth arguably hinged on the resolution 
of this pivotal issue, the foremost issue debated during the Constitutional Convention of 18501851. 
Chapter 4: "Whitening" Politics: Slavery, Politics, and the 1851 Constitution

In November 1851, the Cooper's Clarksburg Register began publication. In its inaugural issue, editor and proprietor William Pope Cooper explained his motives for establishing a weekly newspaper in Harrison County. An avowed exponent of the Democratic Party, Cooper believed that his newspaper would ably serve northwestern Democrats by offering news and political, economic, and social commentary. His analysis of local, state, and national news would be interpreted through a partisan lens, defending the efforts of his party while castigating rivals. Cooper believed that the "great principles of Republicanism avowed by Jefferson" represented the true source of political liberty and independence for white Virginians. As editor, Cooper solemnly declared to use all his journalistic abilities to support and advance that important belief. $^{1}$

The establishment of a partisan newspaper should not be surprising, especially during the prime of the two-party system, when newspapers acted as a critical medium that disseminated and advocated party principles. But the timing of the newspapers' founding reflected what Cooper and other northwesterners' considered to be the beginning of a new political and constitutional era for Virginia. Virginians "have just adopted a new constitution," Cooper exclaimed, expunging the "old relics of monarchy" and replacing them with "enlightened and liberal" democratic principles. This inauguration of democratic reform occurred with increased safeguards for slaveholders woven directly in the new constitution. With slavery interlaced throughout Virginia's political and constitutional structures, the symbiotic nature of democracy and slavery reached full maturation in the Old Dominion in 1851. Cooper, a nonslaveholder, celebrated the constitution's adoption and ratification. ${ }^{2}$

${ }^{1}$ Cooper's Clarksburg Register, November 12, 1851, 2.

${ }^{2}$ Cooper's Clarksburg Register, November 12, 1851, 2. 
After operating approximately two decades under the previous constitution, Virginians elected delegates for the task of rewriting their state constitution. The same democratic reforms that northwesterners demanded in the years preceding the previous constitutional convention were demanded once more in 1850: universal male suffrage, equalized representation in the state legislature, direct election of government officials, and, among other demands, reforming the county court system. Elected representatives assembled in Richmond while northwestern residents anxiously read the convention's proceedings, communicated with their delegates, debated their neighbors on the convention's progress, and anticipated positive news emerging from the state capitol. While the previous constitution disappointed and angered many residents, the new constitution adopted by delegates in 1851 received northwesterners' hearty approbation. The 1851 Constitution contained numerous desired democratic reforms, finally freeing northwestern residents from what many considered aristocratic and antiquated means of determining and vesting power in "the people."

William Cooper celebrated the passage of the new constitution and remarked on what he considered the important changes contained in the new constitution. Universal male suffrage caught the editor's attention. Now, a "large and respectable portion of citizens who have heretofore been deprived of the elective franchise" would enjoy their "birth-right" of enfranchisement. While the 1830 Constitution had increased the electorate beyond the colonial era limits, this new constitution enfranchised practically all white men. These newly enfranchised northwestern residents could exercise this right when they voted for those public officials who "frame[d] and administer[ed]...laws," notably that of the governor and lieutenant governor. (Seizing on this new political structure, Cooper placed the names of Joseph Johnson and Shelton Leake as Democratic candidates for governor and lieutenant governor, respectively, 
near the newspaper's masthead.) Along with universal male suffrage and the direct election of most public offices, a more equalized form of representation in the state legislature and the popular election of judges meant increased political power for northwesterners in state and local affairs. This new constitution inaugurated "the dawn of a new era," exclaimed one northwestern politician. $^{3}$

For many historians, this "new era" represented one of the final, pitched sectional battles before Virginia's dismemberment during the Civil War. Earlier historians such as Theodore Lang and Granville Davisson Hall maintained that the 1851 Constitution clearly revealed the degradation experienced by western Virginians, and that only a division of the state could ensure political equality. Lang contended that "many leading men" in western Virginia "began to devise means for separation" following the new constitution's ratification. ${ }^{4}$ Democratic reform could not overcome the differences manifest in two different societies, differences that Lang emphasized stretched back to the region's "origin of settlement." ${ }^{5}$ Hall perceived in the new constitution the same "Machiavellian hand" that sought to foment disunion and create a southern slaveholding republic, a program solely designed to expand slaveholders' hegemony. According to this interpretation, western Virginians, confronted with this dilemma plotted to divide the state to halt eastern Virginians' slaveholding program. ${ }^{6}$

More recent historians have generally agreed with these previous interpretations. William Freehling argues that the 1851 Constitution "only stalled off [a] class and regional showdown," a conflict continually over slavery and one that would inevitably end with West

\footnotetext{
${ }^{3}$ Journal of the House of Delegates, of the State of Virginia, For the Session of 1852 (Richmond: William F. Ritchie, 1852), 10.

${ }^{4}$ Lang, West Virginia, 4.

${ }^{5}$ Lang, West Virginia, 3.

${ }^{6}$ Hall, Rending of Virginia, 96.
} 
Virginia's creation. ${ }^{7}$ Echoing Theodore Lang, Sean Wilentz contends that antislavery appeals in western Virginia illustrated that "Virginia consisted of two societies encompassed within a single border," and though the 1851 Constitution inaugurated democratic reform, these measures proved insufficient in promoting sectional harmony. ${ }^{8}$ While the Northwest obtained greater political power through the 1851 Constitution, William Link maintains that residents continued to experience and exhibit a feeling of "political isolation" during the 1850s. He argues that residents manifested this "isolation" through various means, including pursuing annexation, gravitating toward the Republican Party, and rejecting secession in $1861 .{ }^{9}$ William Shade suggests that demographic trends in the 1850s signaled an approaching crisis over the issue of slavery. The declining slaveholder population in the state coincided with an increasing nonslaveholder population, especially in the western half of the state. Nonslaveholders, enfranchised by the 1851 Constitution, would invariably, Shade implies, pose an acute political threat to slavery's future in the Commonwealth. ${ }^{10}$ These historians arrive at the same general argument: Virginia's political system had become too ossified to accommodate an increasingly diverse constituency. Demographic, political, constitutional, and economic trends all indicated a looming conflict over the issue of slavery during the proceeding decade. The 1851 Constitution represented only a stop-gap measure, delaying the inevitable rending of Virginia.

But to many Virginians in 1851, the new constitution did indeed inaugurate the "dawn of a new era." For decades, western, disenfranchised nonfreeholders demanded political and constitutional equality on par with their enfranchised and propertied brethren east of the Blue Ridge. Though western reformers endured setbacks, notably in 1830, the 1851 Constitution

\footnotetext{
${ }^{7}$ Freehling, Road to Disunion: Secessionists at Bay, 515.

${ }^{8}$ Wilentz, Rise of American Democracy, 589, 698.

${ }^{9}$ Link, Roots of Secession, 9.

${ }^{10}$ Shade, Democratizing the Old Dominion, 285.
} 
represented a resounding triumph. Northwesterners could now claim membership in an inclusive democratic political system, one that offered broad political rights and guaranteed political representation for all white men. Residents cheered the constitution's recognition of majoritarian power, a principle that resonated with the memory of the American Revolution and validated arguments about man's "natural right" to self-government. The new constitution's safeguards for slavery and slaveholders angered few, with some maintaining that these measures amounted to a compromise between eastern and western Virginians that would allay sectional tensions. Residents displayed their overwhelming support for the constitution by their actions, too, overwhelmingly voting to ratify the constitution.

The articles concerning slaves and slavery in the 1851 Constitution represented the first such references in the state's constitutional history. Along with capping the amount slaves could be taxed, the new constitution placed restrictions on private manumission and curtailed the General Assembly's power to emancipate slaves. These articles strengthened and protected slavery and slaveholders' interests, manifesting the ideas envisaged by proslavery advocates Leigh and Upshur. By fusing slavery and republican government, Virginians ensured the health and longevity of both institutions, effectively making them inseparable. As questions concerning slavery's future continued to surface throughout the 1850 s, Virginia proslavery advocates took solace knowing that white Virginians would interpret any threat to slavery as a threat to their political independence. The new constitution turned white Virginians in all the state's regions into proslavery foot soldiers.

According to nearly all the previous scholars of the topic, white northwesterners turning into proslavery foot soldiers should have increased sectional tension and hastened the statehood movement. But residents deepened their commitment to slavery and the state, embracing the 
fundamental southern axiom that black bondage protected white liberty. Residents championed the rights of slaveholders, denounced the wicked machinations of abolitionists, and defended themselves against accusations questioning their loyalty to slavery and Virginia.

Northwesterners intensified their engagement in the "politics of slavery" as whiteness emerged as the sole factor demarcating freedom from bondage, with residents attacking those who threatened to upset established political and racial hierarchies and relationships. The inauguration of democratic reform in Virginia in 1851 deepened northwesterners' fealty toward slavery and the state.

Delegates to the 1850-1851 Constitutional Convention reflected the changing political, social, and economic dynamics that had been unfolding in the state over the past two decades. The Revolutionary generation had generally faded away, while the number of prominent planters and slaveholders had dwindled, too. Professional men, including lawyers, doctors, and merchants, comprised the majority of delegates to the new constitutional convention. Only a handful of planters and even fewer large slaveholders attended. ${ }^{11}$ Northwestern delegates embodied the rise of this new professional class in the Old Dominion. Over half of the thirteen Northwest delegates practiced law, with others claiming occupation as a millwright, saddler, merchant, and farmer. ${ }^{12}$ At least five delegates were born outside of Virginia, notably four born in northern, nonslaveholding states. ${ }^{13}$ Approximately half of the Northwest delegation was slaveholders, including Waitman T. Willey, Gideon D. Camden, and Joseph Johnson, though

\footnotetext{
${ }^{11}$ Tarter, Grandees of Government, 189 and Shade, Democratizing the Old Dominion, 174-178.

${ }^{12}$ Waitman T. Willey (Monongalia), John S. Carlile (Barbour), Gideon D. Camden (Harrison), James Neeson (Marion), William G. Brown (Preston), Peter G. Van Winkle (Wood), Zachariah Jacob (Ohio), and John F. Snodgrass (Wood) all practiced law. Jefferson Martin (Marshall) was a millwright; John Knote (Ohio) was a saddler; Edward J. Armstrong (Taylor) was a merchant; and Joseph Johnson (Harrison) farmed.

[Ancestry.com] [accessed 23 April 2015]

${ }^{13}$ James Neeson (Pennsylvania), Joseph Johnson (New York), Peter G. Van Winkle (New Jersey), John Knote (Pennsylvania), and Zachariah Jacob (Maryland) had immigrated to Virginia. The other members were native-born Virginians. [Ancestry.com][accessed 23 April 2015]
} 
none were planters or large slaveholders. ${ }^{14}$ Northwest delegates embodied the rise of the new professional class, and manifested their identification as Virginians through their status as slaveholders.

Delegates gathered in Richmond in October 1850 to amend the state constitution. Northwestern delegates gained an important victory in the convention's initial month when they secured the convention's adjournment until the following January when data from the 1850 U.S. Census would become available. ${ }^{15}$ The census confirmed northwesterners' claims about Virginia's antidemocratic and antiquated political structures and functions. While the majority of whites resided west of the Blue Ridge, property restrictions limited their political representation and the overall power wielded by residents and their representatives. ${ }^{16}$ As Taylor County residents argued, the "free white population" represented "the only true basis of republican government." The denial of majoritarian power constituted a tyrannical government unfit for free men as it threatened the important principle of "political equality." Residents demanded what they considered their constitutional rights as a numerical majority. ${ }^{17}$

Eastern Virginians, though a minority, wielded majoritarian power and effectively controlled the state government. And many eastern delegates wanted to perpetuate that power to protect their interest in slaves. National events concerning African American bondage during the 1840s made the institution appear more vulnerable, including the arrival of abolitionism and free

\footnotetext{
${ }^{14}$ Waitman T. Willey and John F. Snodgrass both owned five slaves; Gideon Camden and Edward J. Armstrong each owned seven slaves; and Joseph Johnson owned two slaves. [Ancestry.com][accessed 23 April 2015]

${ }^{15}$ Rice and Brown, West Virginia, 97.

${ }^{16}$ By 1850 , the white population in the West was 494,763 compared to 401,104 in the East. The slave population in the East was 411,379 and 63,234 in the West. University of Virginia Geospatial and Statistical Data Center: Historical Census Browser [http://mapserver.lib.Virginia.edu/php/newlong2.php] [accessed 1 March 2015 to 3 March 2015]. The growth of slavery in the Shenandoah Valley further complicated the political and sectional dynamics during the Convention, as their interests became increasingly tethered to those of the Piedmont and Tidewater and away from the Northwest.

${ }^{17}$ Virginia Reform Convention, 168.
} 
soilism on Virginia's borders. ${ }^{18}$ Demographic trends within the state augmented those fears, notably those unfolding in the Northwest. Delegates John Knote of Ohio County and Jefferson Martin of Marshall County supported publishing the convention's proceedings in German so their German constituents could follow the convention's progress. ${ }^{19}$ Many eastern politicians considered these German immigrants, refugees of the failed 1848 Revolution, as a dangerous populace that understood little of Virginia's political culture or its institutions. Virginians' sanguinity expressed prior to the convention faded as they sparred over reforms and the impact of those reforms on slavery. This focus on slavery during the convention differed sharply from the previous convention, where reformers and anti-reformers debated the efficacy of the freehold and property qualifications.

During the convention's opening weeks, Tidewater and Piedmont delegates, wary of the possible deleterious effects of democratic reform on slavery, denounced reformers' schemes and ideas as dangerous and subversive. Reformers" advocacy of the "white basis" plan of representation, universal suffrage, and the popular election of public officials threatened to elevate uneducated, crude, nonslaveholders into a position of immense power. Halifax County delegate George W. Purkins contended that "the people" certainly did not include that mass of western nonslaveholders who clamored for political representation. Rather, "the people" meant a "political community" of men who shared overwhelming identical interests. In the context of Virginia politics, that "political community" meant slaveholders, a powerful demographic that

\footnotetext{
${ }^{18}$ For example, see Shepherdstown Register, March 5, 1850, 2; W.W. Arnett to Waitman T. Willey, 7 April 1838, Charles H. Ambler Collection, A\&M 122, Box 10, Folder 1, Item 38, WVRHC; W.D. Lemmon to Waitman T. Willey, 16 October 1844, Charles H. Ambler Collection, A\&M 122, Box 10, Folder 2, Item 78, WVRHC; and, W.W. Arnett to Waitman T. Willey, 22 September 1848, Charles H. Ambler Collection, A\&M 122, Box 10, Folder 3, Item 99, WVRHC.

${ }^{19}$ Virginia Reform Convention, 32, 54, 55.
} 
wielded immense state and local power over their slaves and, according to reformers, exercised that mastery over white men, too. ${ }^{20}$

But if reformers resented the mastery wielded by eastern legislators over white men, these eastern legislators feared that a reformed political system would allow western white men to lord over slaveholders. Richmond delegate R.C. Standard perceived in a "democracy of numbers" the characteristics of "naked and unmitigated Dorrism[.]" Standard's reference to the Dorr Rebellion in Rhode Island in the early 1840s reminded delegates of the militant and aggressive tactics employed by democratic reformers. Such scenes of anarchy would unfold in the Old Dominion if Virginians opened politics to the masses, he warned. ${ }^{21}$ Fauquier County delegate and slaveholder Judge Robert E. Scott, annoyed by reformers' majoritarian arguments, wondered how much longer Virginians would be forced to listen to westerners' "eternal demands" that "mere numbers" should constitute the basis for republican government. The "white basis," he warned, would not provide "protection to property" but would instead "lay it open to be plundered at the discretion of a mere majority." Once vested with legislative power, nonslaveholders would impose draconian taxes on slaveholders to pay for internal improvements, effectively taxing slavery out of existence. The "mixed basis" provided the "only adequate protection" for slaveholders, Scott maintained. All other schemes of representation were hostile to Virginia's slaveholding interests. ${ }^{22}$

Opponents of reform claimed that democratic reform, notably the principle of majoritarian rule, closely resembled the dangerous "isms" gaining acceptance in the North.

\footnotetext{
${ }^{20}$ Speech of George W. Purkins, Esq., of Halifax, in the Committee of the Whole, on the Basis Question, Delivered in the Virginia Reform Convention, on Friday, February 21, 1851 (Richmond: R.H. Gallaher, 1851), 6.

${ }^{21}$ R.C. Standard, Esq., of Richmond City, in Committee of the Whole, on The Basis Question, Delivered in the Virginia Reform Convention, on Thursday, April 17, and Wednesday, May 21, 1851 (Richmond: R.H. Gallaher Republican Office, 1851), 7, 8.

${ }^{22}$ Virginia Reform Convention, 284.
} 
Chief among these was free soilism. Standard warned that the "white basis," if inaugurated by the convention, would engender the same sentiments in the General Assembly as those harbored in the House of Representatives, "that northern...antislavery...almost free soil house." Could Virginia's "slaveholding interest expect favor...[or] justice" from either body? ${ }^{23}$ James Barbour of Culpeper County castigated reformers' who argued that slaveholders' antipathy for majoritarian rule precluded political representation for white men. Barbour interpreted in this argument the ideological foundation "upon which the free soil party of the north bases itself." Westerners" assertions that "slave labor is an interference with the rights of free men" mirrored the free soil and free labor arguments articulated by the nascent and northern Free Soil Party. ${ }^{24}$ The presence of free soilism in Ohio and Pennsylvania, along with rumors of free soil meetings in Virginia, made such accusations appear more manifest. Opponents of democratic reform perceived in reformers' cries ideas and values that had been transmitted across the Mason-Dixon Line. "[Y]our democracy is too much of northern origin," complained one conservative to a northwest delegate. ${ }^{25}$ The moral was clear. The style of democracy supported by northwestern reformers appeared tainted by northern values and ideas, notably a visceral aversion toward slavery. And if free soilism could be inaugurated in the Old Dominion, what other northern "isms" could Virginians also embrace?

Reformers' arguments extolling man's natural right to self-government likewise reflected an invasion of northern principles designed to undermine slaveholders' hegemony. Mecklenburg County delegate and planter William O. Goode reminded the convention that a "numerical

\footnotetext{
${ }^{23}$ Standard, Basis Question, 17.

${ }^{24}$ James Barbour, Speech of James Barbour, Esq., of Culpeper, in the Committee of the Whole, on the basis question, delivered in the Virginia Reform Convention, on Thursday, February 27, 1851, (Richmond: R.H. Gallaher, 1851), 12.

${ }^{25}$ Virginia Reform Convention, 117.
} 
majority is no where recognized in our system" of government. Goode seized on a similar objection noted by his predecessors in the previous convention. Did "females" and "little children" possess these same natural rights as reformers' claimed white men held? ${ }^{26}$ Standard furthered Goode's argument, adding that "convicts and paupers" would be invited to the polls under universal suffrage and enjoy representation under the "white basis." 27 Westmoreland County delegate and planter Richard L.T. Beale considered the whole natural rights argument an "absurdity." No "secret law of nature" existed that bestowed political virtue to men or qualified them to vote. The basis for political representation emerged from society, Beale concluded, and Virginia's political community demanded that politics reward property owners. ${ }^{28}$

For Beale and his ilk, property qualifications ensured a constant and stable government with structures and functions in place that mitigated, if not eliminated, the capriciousness and volatility of public opinion. Indeed, the current structure of the state government prevented what Judge Scott of Fauquier considered the "dangerous turbulence of democracy" from convulsing the body politic. ${ }^{29}$ If the convention adopted the "white basis," uneducated and malleable voters (who could be easily plied with alcohol or patronage) threatened to instigate a revolution that would overturn established political hierarchies. ${ }^{30}$ A state government organized under the

\footnotetext{
${ }^{26}$ William O. Goode, Speech of William O. Goode, Esq., of Mecklenburg, in Committee of the Whole, on the Basis Question, delivered in the Virginia Reform Convention, on Wednesday, April 16, 1851 (Richmond: R.H. Gallaher Republican Office, 1851), 11.

${ }^{27}$ Stanard, Basis Question, 6.

${ }^{28}$ Virginia Reform Convention, 313.

${ }^{29}$ Virginia Reform Convention, 339.

${ }^{30}$ The notion that democratic elections would devolve into debauchery held tremendous sway with many elite eastern Virginians who worried that public opinion, if not tethered to propertied interests, would swing violently and unpredictably. Examples from other states added to these fears. In Alabama, a state organized with universal male suffrage, one eastern Virginia reported seeing public officials "trampoozing the whole state, calling upon the people to attend barbecues and frolics of all kinds" as these politicians pandered for votes. For months this scene unfolded across the state, with large numbers of Alabamians under "the potent influence of the delicious fumes of whiskey." "[U]niversal suffrage voters were called to drink deep" on election day, and "sober voters," needed to "take the votes of the drunken ones," were few in number. Such scenes appeared disgraceful to elite Virginians, who considered politics and government a gentlemanly pursuit designed to vest power in educated men who swore to protect the health of the republic. The drunkenness and pandering exhibited by Alabamians represented an
} 
"white basis" could permit a spontaneous "call [for] a new convention" where that majority would "expunge from the constitution any provision" deemed incongruous to political equality. ${ }^{31}$ Slaveholder and Prince George County delegate Timothy Rives wondered if reformers' pursuit of democracy would lead them to dismantle the "long tried practice of the past" and "abandon customs" that had protected the rights of property holders. Rives prayed that reformers would restrain their "radical hands" before they inflicted irreversible damage. ${ }^{32}$

To prevent the inauguration of democratic reform in Virginia, anti-reformers wielded every rhetorical weapon in their arsenal. The memory of the French Revolution once again acted as a powerful means to manifest democracy's excess. Events like the French Revolution occur, an eastern delegate argued, when the government left the "power of the people...entirely unrestricted." ${ }^{33}$ Indeed, the "blood-stained records of revolutionary France" constituted the only evidence needed to elucidate the danger of democratic reform. ${ }^{34}$ Other delegates equated the furor for democratic reform to a volcano. Volcanoes erupted unpredictability and indiscriminately, destroying everything in its path. The "smoldering volcano" west of the Alleghenies threatened to destroy the republic, immersing Virginians into a Hobbesian state of nature where brute force and mere numbers, not intellect or private property, would govern the state. The dangers of democratic reform necessitated a full defense of the current structure of the state government. ${ }^{35}$

An unabashed defense of slavery and the need to protect slaveholders stood at the core of anti-reformers' arguments. This focus on the peculiar institution reflected an abandonment of

\footnotetext{
outgrowth of universal suffrage and ultimately seemed beneath many of these Virginias. Views of the Constitution, 10-11. [emphasis in original].

${ }^{31}$ Standard, Basis Question, 16.

${ }^{32}$ Virginia Reform Convention, 120.

${ }^{33}$ Virginia Reform Convention, 226.

${ }^{34}$ Virginia Reform Convention, 346.

${ }^{35}$ Virginia Reform Convention, 240.
} 
the freehold, a process begun in the post-Nat Turner years and initiated by Leigh, Dew, and Upshur. Delegates' preoccupation with slavery also reflected their increasing concern over slavery's future in a nation with more voices opposing African American bondage.

Northwestern Virginians' demands for reforms, William Goode lamented, “directed the attention of the northern abolitionists, and of the English abolitionists" who might conclude that the "slave holder is weak in Virginia, and...weak throughout the south." Though he denied that conclusion, Goode worried that abolitionists reading the debates could infer that proslavery advocates in the Old Dominion were on the defensive. ${ }^{36}$

Many Tidewater and Piedmont delegates simply believed that enfranchising the state's growing nonslaveholder population would imperil slavery. Examples of other southern states having undergone a thorough democratization without any danger to slave property failed to convince eastern delegates. As Scott argued, the "homogenous interests" in Georgia, Mississippi, and Alabama facilitated democratic reform because a majority of the population manifested a strong investment in slavery. The meager slave population in the Northwest and across western Virginia illustrated that westerners possessed different interests than easterners. ${ }^{37}$ Reformers, cried Standard, asked slaveholders to place "legislative power... in that section in which slave property scarcely exists at all."38 Culpeper delegate James Barbour echoed similar sentiments. "I tremble when I anticipate the day," he declared, "when the unrestricted control over the powers of this government shall pass into hands not interested in the preservation of that

\footnotetext{
${ }^{36}$ Goode, Basis Question, 21.

${ }^{37}$ Virginia Reform Convention, 342.

${ }^{38}$ Standard, Basis Question, 16.
} 
property." 39 Reformers possessed no "natural right to seize my property," Scott declared, and on this position many easterners refused to compromise. ${ }^{40}$

Northwestern reformers confronted an immense challenge refuting what Waitman T. Willey considered the "inferential impeachment of western integrity," specifically that western Virginians could not be trusted on the issue of slavery. ${ }^{41}$ Refuting this accusation took different forms. John S. Carlile declared himself to be a "Virginian by birth" and a proud "Southern man" who posed no danger to the state's institutions. ${ }^{42}$ To demonstrate his constituents' fealty toward slavery and the state, Willey introduced resolutions passed at two different reform meetings held in Morgantown. These resolutions expressed residents' unwavering support for democratic reforms, notably the "white basis," universal male suffrage, and the election of government officials from the governor down to the local courts. Within these demands, Monongalia residents also supported "a sufficient constitutional guaranty" that would "amply and fully" protect property rights, specifically that of slaveholders. ${ }^{43}$ Though "not entitled to representation," private property, including that in slaves, required "just and full protection."44 Gideon Camden introduced resolutions adopted at a similar reform meeting in Harrison County, reemphasizing his constituents' belief that democratic reform could occur with greater protection for slavery. ${ }^{45}$

Such resolutions extolling northwesterners' fealty, though, appeared as paper guarantees in the eyes of some eastern delegates. These guarantees could be easily revoked or forgotten

\footnotetext{
${ }^{39}$ Virginia Reform Convention, 372.

${ }^{40}$ Virginia Reform Convention, 341.

${ }^{41}$ Waitman T. Willey, Speeches of Waitman T. Willey of Monongalia County, before the State Convention of Virginia, on the Basis of Representation; on County Courts \& County Organization, and on the Election of Judges by the People (Richmond: William Culley, Printer, [1851]) 15.

${ }^{42}$ Virginia Reform Convention, 117.

${ }^{43}$ Virginia Reform Convention, 15, 16.

${ }^{44}$ Virginia Reform Convention, 30.

${ }^{45}$ Virginia Reform Convention, 306.
} 
once residents achieved reform. James Barbour of Culpeper stated flatly that he did "not believe in these guaranties, or their efficacy," believing that the majority would "purge" the constitution of these safeguards once residents deemed them "onerous" and "objectionable" to political equality. ${ }^{46}$ Marion County delegate James Neeson denied such accusations, reminding eastern delegates that the "only protection" for slavery rested on expanding political rights for western white men. National crises concerning slavery should serve to remind slaveholders that true security for the peculiar institution rested on securing allies, not alienating neighbors. Other slaveholding states had democratized their state constitutions and "no injury has ever been inflicted on slave property," Neeson maintained. Slaveholders in these states realized that nonslaveholders governed "wisely and faithfully, with due regard to all interests." A government constructed on "injustice...must fall," he averred. But if delegates "constitute a government" on democratic principles they would produce "brave and powerful" allies who would provide "security" for slaveholders and support their rights during the "hour of...direst need." A democratic government would strengthen, not endanger, slavery. ${ }^{47}$

Preston County delegate William G. Brown echoed Neeson's arguments, emphasizing that democratic reform would secure allies who would support slavery against foes from within and without. Northwesterners are "loyal to Virginia and to all her institutions," he declared. Brown considered the "duty of society to guard carefully" property rights, including through "constitutional guarantees and legal enactments." For years, northwesterners had manifested their "affections and our support" for slavery, proving themselves loyal allies to slaveholders. Brown assured delegates that his constituents' fealty would continue "in the future" if the eastern slaveholders would recognize their transmontane neighbors as "equals." But the continued

\footnotetext{
${ }^{46}$ Barbour, Basis Question, 11.

${ }^{47}$ Virginia Reform Convention, 476-477.
} 
denial of political representation to western whites could prove catastrophic, Brown warned.

"There can be no peace in Virginia," he cautioned, “...until all odious political discriminations

are forever abolished." ${ }^{28}$ Like Neeson, Brown expressed little difficulty in granting political and constitutional safeguards to eastern slaveholders. In return, both men asked for political representation for their constituents, a move that would promote unity between slaveholders and nonslaveholders and ease sectional tensions.

No other northwestern delegate, though, provided a clearer and more powerful articulation of his constituents' position on slavery and democratic reform than Monongalia's Waitman Thomas Willey. Willey, a noted Whig, slaveholder, and lawyer who had trained under democratic reformer Philip Doddridge, fervently believed that greater security for slavery could be achieved through the process of political and constitutional democratization. He reminded delegates that, outside of South Carolina, the majority of states operated under some form of the "white basis." Importantly, slave property remained secure in those states. ${ }^{49}$ Eastern delegates' claims that the "possession of lands and tenements, goods and chattles" reflected "superior political authority" and required protection through the "mixed basis" were "abhorrent" and calculated to increase tensions between slaveholders and nonslaveholders. Property bestowed neither "virtue" nor "wisdom to its possessor," he argued. Rather, the memory of the American Revolution mandated that all white men possess equal political power regardless of property, intellect, or birthright. By securing majoritarian rule, Virginians would also secure slavery. ${ }^{50}$ Willey believed that Virginia slaveholders needed this extra protection for slavery because the institution's future seemed uncertain. The "encroachments and menaces of Northern

\footnotetext{
${ }^{48}$ Virginia Reform Convention, 321.

${ }^{49}$ Willey, Speech of Waitman T. Willey, 4-5.

${ }^{50}$ Willey, Speech of Waitman T. Willey, 8.
} 
fanaticism" had made slaveholders "justly alarmed" about not only northerners but nonslaveholders residing in Virginia. ${ }^{51}$ But Willey considered the latter fears unfounded and "idle." The expansion of slavery in the Shenandoah Valley and across southwest Virginia ensured that no "western majority would or could oppress the eastern slave holder by exorbitant taxation, or by any enactment affecting slave property." 52 Willey even supported a "constitutional limitation" on the legislature's "taxing power" to protect slaveholders' property. ${ }^{53}$ Further, he emphasized his constituents' fealty toward slavery and their support for extra protection for slaveholders. Northwesterners supported "just and equal protection" for all forms of property, including slaves, and delegates needed to only look to the historical record for evidence of their unwavering support for slaveholders' rights. ${ }^{54}$ Northwesterners had "united" with eastern Virginians on the issue of slavery in the past and looked forward to maintaining that unity in the future..$^{55}$

But ultimately slavery's future hinged on democratic reform. "Give us our natural rights,” Willey maintained, “... and you secure our fidelity forever.” The bonds of common interest produced by a thorough democratization of the state constitution would generate a powerful and resilient form of political unity that would withstand national or state crises concerning slavery. "You will bind us to your interests and your fortunes, by ties ten-fold stronger than any...legislative majority can devise," he proclaimed. Northwesterners would mobilize "by [the] thousands" against the "leprous hand" of "Northern fanaticism" and against

\footnotetext{
${ }^{51}$ Willey, Speech of Waitman T. Willey, 17-18.

${ }^{52}$ Willey, Speech of Waitman T. Willey, 14-15. Willey's statement referring to the expansion of slavery into southwest Virginia producing stronger bonds between western Virginians and those in the Tidewater and Piedmont confirms Ken Noe's interpretation about the impact of the Virginia and Tennessee Railroad. Noe, Southwest Virginia's Railroad.

${ }^{53}$ Willey, Speech of Waitman T. Willey, 12.

${ }^{54}$ Willey, Speech of Waitman T. Willey, 11.

${ }^{55}$ Willey, Speech of Waitman T. Willey, 17.
} 
the "dark demon of insurrection." Eastern Virginians would not be surprised at this swift and passionate response, for northwesterners" "liberty and honor" would rest on the health of African American bondage. ${ }^{56}$

The benefits of a democratic slaveholding republic were immense and profound; the failure to inaugurate democratic reform, though, could prove detrimental to slavery's future in Virginia. If eastern delegates adopted the "mixed basis" over northwestern objections they would initiate "tumult and [an] alienation of fraternal feelings" and witness the destruction of "peace and concord." 57 Why would northwesterners "ardently and cordially support negro slavery, when by so doing they are virtually cherishing the property which is making slaves of themselves?" 58 Willey dismissed the possibility that abolitionism would gain a foothold in the Northwest, but warned that "a hostility to slavery" could develop among residents who believed that eastern Virginians cherished their chattel more than white equality. This "hostility" could eventually "excite a species of political abolition" against slavery and "an attitude of antagonism" against slaveholders. The failure to inaugurate democratic reform would produce dire consequences. Increased sectional tensions, widened divisions between slaveholders and nonslaveholders, and allies turning into enemies could unfold in the Commonwealth. Slavery would not be protected; it would be placed in greater peril. ${ }^{59}$

Willey's remarks during the convention provide important insight into how northwestern residents understood the dynamic between slavery and democracy. Much like his constituents, Willey did not oppose slaveholders or their right to govern their chattel. ${ }^{60}$ As a slaveholder

\footnotetext{
${ }^{56}$ Willey, Speech of Waitman T. Willey, 18.

${ }^{57}$ Willey, Speech of Waitman T. Willey, 18.

${ }^{58}$ Willey, Speech of Waitman T. Willey, 19.

${ }^{59}$ Willey, Speech of Waitman T. Willey, 19.

${ }^{60}$ William Link argues that both Willey and Carlile were "western white militants [who] opposed slaveholder power" during the convention. However, both delegates defended slaveholders' rights to private property and
} 
himself, Willey considered the "title to this property...sacred." ${ }^{61}$ But northwesterners objected to eastern slaveholders' use of slaves and the issue of slavery to deny majoritarian rights. Such actions smacked of a betrayal and a denial of core republican principles achieved during the American Revolution, an event that demonstrated the political fitness of all white men. Eastern slaveholders' insistence on the "mixed basis" appeared to elevate African Americans to a position in politics reserved solely for white men. If forced to choose between protecting slavery or acquiring their natural political rights, practically all northwesterners would choose the latter. But reform could resolve this conflict. Residents believed that democratic reform would satisfy all Virginians: white, nonslaveholders would achieve the political representation and independence they had long sought while slaveholders would gain greater security for their chattel. ${ }^{62}$

The pleas and pronouncements from northwestern delegates failed to convince enough eastern delegates to adopt reform measures. The convention deadlocked on multiple occasions during early 1851 , and whispers of adjournment or a division of the state quickly surfaced. In the Northwest, residents reached out to their delegates to offer advice and present their perspective about the convention's most pressing issues. George S. Ray, a farmer from Ohio County, expressed his fears about the convention's progress. ${ }^{63}$ Ray worried that delegates from the Shenandoah Valley, aware of slavery's increasing importance to their region, would "play false in the hour of need" and caucus with eastern slaveholders. This coalition would inevitably

supported some form of extra protection for slaveholders in a reformed, democratic political system. Link, Roots of Secession, 19.

${ }^{61}$ Willey, Speech of Willey, 15.

${ }^{62}$ For identical arguments from other another prominent western delegate, see John Letcher, Speech of John Letcher, Esq., of Rockbridge, on the Basis Question. Delivered in the Committee of the Whole Convention, March 14, 1861 (Richmond: Ritchies and Dunnavant, 1851).

${ }^{63} 1850$ U.S. Federal Census, District 44, Ohio, Virginia; Roll: M432_966; Page: 34B; Image: 75

[Ancestry.com][accessed 24 April 2015] 
foil any attempts at reform. If this occurred, "our people will be dissatisfied," he lamented. Residents "will naturally begin to enquire into the subject ... and begin to feel and know that it is the slave power that is ruling over them." "[A] hostility to the peculiar institution" would emerge in the region "which will in the end make Virginia a free state." Ray believed that if the convention failed to properly situate slavery within the state's electoral system, northwesterners would continue to "feel" that the slave power manipulated politics and that enslaved property represented the source of political inequality. This feeling among residents would manifest into an antagonistic spirit toward slavery that could threaten the institution. ${ }^{64}$

Other residents joined in this vibrant debate on slavery and democratic reform. Practically all residents assailed the "mixed basis" and eastern legislators' attempts to use that formula to calculate representation. If easterners ratified a constitution with the dreaded "mixed basis," the Wellsburg Weekly Herald declared, northwesterners would be "Virginia slaves to slave masters." Western delegates needed to continue supporting the "white basis," the newspaper concluded ${ }^{65}$ Fairmont lawyer Alpheus F. Haymond felt his neighbors becoming jaded and frustrated because of eastern delegates' continued intransigence on reforms. "The people of the West," he asserted, "will no longer submit to the present odious constitution and neither will they submit to the mixed basis proper." ${ }^{66}$ John G. Burdett, a farmer from Taylor County, commented that "a respectable group of citizens are...discussing the pros. and cons. of the recent developments" in the convention. The "feeling of our people," he concluded, "are

\footnotetext{
${ }^{64}$ George S. Ray to Waitman T. Willey, 22 January 1851, Charles H. Ambler Collection, A\&M 122, Box 10, Folder 3 , item 131, WVRHC. [emphasis in original]

${ }^{65}$ Wellsburg Weekly Herald, March 21, 1851, 2.

${ }^{66}$ A.F. Haymond to Waitman T. Willey, 28 April 1851, Charles H. Ambler Collection, A\&M 122, Box 10, Folder 3, item 137, WVRHC and 1850 U.S. Federal Census, Western District, Marion, Virginia; Roll: M432_958; Page: 189A; Image: 379 [Ancestry.com] [accessed 13 April 2015].
} 
against compromis[ing] what is humbly conceived to be our rights."67 Parkersburg residents, though "loyal" to the state, remained "unanimous" in their support for the "white basis." Eastern Virginians needed to "repent" from their "reckless indifference" toward the West and cease the "monstrous" injustice they imposed on northwesterners. ${ }^{68}$

Frequently residents' discussions of the convention centered on whether western Virginians should pursue a division of the state if eastern delegates rejected democratic reforms. Nearly all residents declared that such action should only be a last resort or ultimatum used to convince eastern delegates to compromise. ${ }^{69}$ Burdett "hope[d]" that Virginia would remain united, finding it "painful" that members of "the same family" bickered over issues that should unite, not divide, them. He supported a "divorce," though, should eastern Virginians continue to place northwesterners in "unequal and degrading conditions."70 In a constitutional reform meeting held in Wood County, residents “deplore[d] any movement tending towards a separation of Virginia," and that dividing the state should only be advocated if the "anti-republican and oppressive" mixed basis be adopted. ${ }^{71}$ Monongalia County attorney Ralph L. Berkshire cautioned northwestern delegates about actively pursuing dismemberment. "[A] division of the State will not I am confident, be popular with our people though it may be politic to threaten the East with it," he maintained. Withdrawing from the convention to precipitate a division should

${ }^{67}$ John S. Burdett to Waitman T. Willey, 28 April 1851, Charles H. Ambler Collection, A\&M 122, Box 10, Folder 3, item 138, WVRHC and 1850 U.S. Federal Census, District 63, Taylor, Virginia; Roll: M432_978; Page: 210A; Image: 413 [Ancestry.com] [accessed 14 April 2015].

${ }^{68}$ Parkersburg Gazette and Western Virginia Courier, March 22, 1851, 2.

${ }^{69} \mathrm{My}$ interpretation here differs from that offered by William Link. Link argues that "some western radicalsespecially from the Northwest-welcomed state separation" and that "western secession loomed over the convention." While some residents did express a desire for a division of the state to their representatives, practically all of these pronouncements were contingent upon all possible political and constitutional channels being explored and exhausted first. Most residents continued to express fealty and support to the state and slavery, demanding only what they considered their fundamental political rights. Link, Roots of Secession, 23.

${ }^{70}$ John G. Burdett to Waitman T. Willey, 28 April 1851, Charles H. Ambler Collection, A\&M 122, Box 10, Folder 3, item 138, WVRHC.

${ }^{71}$ Parkersburg Gazette and Western Virginia Courier, May 3, 1851, 2. 
only be a "last resort." The widespread support for compromise measures in Monongalia and Preston counties convinced Berkshire that residents would approve any new constitution. ${ }^{72}$ In nearby Harrison County, Circuit Court Judge George H. Lee, a slaveholder, reminded Gideon Camden that of the resolutions passed at a constitutional reform meeting, the first "affirmed the close attachment of the western people to Virginia as she is."73 Harrison County farmer and slaveholder Caleb Boggess believed that western Virginians should only separate after "having exhausted all...peaceful efforts to attain our rights." 74 The interpretation that northwesterners actively pursued a division of the state overlooks the hesitancy and caution expressed by residents. Demanding a division of the state communicated to other Virginians the serious injustice of the "mixed basis." Northwesterners desired to remain Virginians; they also demanded what they considered their fundamental political rights. On this latter issue few residents were willing to compromise.

Accomac County delegate Henry A. Wise emerged as the principal figure in brokering a compromise between reformers and anti-reformers. Though a slaveholder from Virginia's Eastern Shore, Wise often caucused with western reformers and supported their pursuit of democratic reforms. His alliance with western reformers manifested his dogmatic belief that democratic reform would strengthen and protect slavery, not endanger the institution. ${ }^{75}$ Eastern

\footnotetext{
${ }^{72}$ Ralph L. Berkshire to Waitman T. Willey, 30 April 1851, Charles H. Ambler Collection, A\&M 122, Box 10, Folder 3, item 139, WVRHC [emphasis in original] and 1850 U.S. Federal Census, Eastern District, Monongalia, Virginia; Roll: M432_961; Page: 257B; Image: 123 [Ancestry.com] [accessed 13 April 2015].

${ }^{73}$ George H. Lee to Gideon D. Camden, 17 February 1851, Gideon D. Camden Collection, A\&M 1199, Box 2, Folder April 1851 to July 1851, WVRHC; 1850 U.S. Federal Census, District 21, Harrison, Virginia; Roll: M432_950; Page: 161B; Image: 329 [Ancestry.com] [accessed 14 April 2015]; and 1850 U.S. Federal Census Slave Schedules, Harrison County, Virginia [Ancestry.com] [accessed 14 April 2015].

${ }^{74}$ Caleb Boggess to Gideon D. Camden, 18 May 1851, Gideon D. Camden Collection, A\&M 1199, Box 2, Folder April 1851 to July 1851, WVRHC; 1850 U.S. Federal Census, District 21, Harrison, Virginia; Roll: M432_950; Page: 149B; Image: 305 [Ancestry.com] [accessed 13 April 2015]; and 1850 U.S. Federal Census - Slave Schedules, Harrison County, Virginia [Ancestry.com] [accessed 13 April 2015].

${ }^{75}$ Craig Simpson, "Political Compromise and the Protection of Slavery: Henry A. Wise and the Virginia Constitutional Convention of 1850-51," Virginia Magazine of History and Biography, 83, no.4 (October 1975): 387 405.
} 
Virginians continued resistance and support of a "fundamentally aristocratic and antirepublican" electoral system threatened to turn western allies into enemies. ${ }^{76}$ The "democracy" championed by eastern delegates appeared as a derivative of the "Adams school," a political system controlled and manipulated by patricians solely for their benefit. In embracing this corrupted form of "democracy," eastern delegates "den[ied] the sovereign power of the people!" And by rejecting majoritarian rule, Wise declared, Tidewater and Piedmont delegates threatened to destroy the institution they sought to protect. ${ }^{77}$

Wise, an unabashed "pro-slavery man," believed that the continued denial of westerners' political representation would inexorably array thousands of Virginians against slavery. The "worst enemy of slavery" were not northern Free Soilers or abolitionists, he asserted, but in the exclusion of the "free white population in Western Virginia." Implementing the "mixed basis" represented a misguided and dangerous action on the part of eastern delegates. For without adequate political representation, he warned, northwesterners would perceive themselves as equivalent to chattel. But enfranchising westerners would generate proslavery allies who would defend the institution. Wise's support for "free, equal and universal suffrage" and the "white basis" reflected his belief that democratic reforms offered "the best protection, not only to persons but to property." True security for slavery and slaveholders rested not in restricting the number of those who possessed a stake in the institution; true security for the institution rested on showering its benefits on all white men. ${ }^{78}$

\footnotetext{
${ }^{76}$ Henry A. Wise quoted in Barton H. Wise, The Life of Henry A. Wise of Virginia, 1806-1876 (New York: The MacMillan Company, 1899), 145.

${ }^{77}$ Henry A. Wise, Speech of Hon. Henry A. Wise of Accomac, in the Committee of the Whole, on the Basis Question, Delivered in the Virginia Reform Convention on Wednesday, Thursday, Friday, Saturday, Monday, April 23, 24, 25, 26, and 28, 1851 (Richmond: R.H. Gallaher, 1851), 7.

${ }^{78}$ Wise, Speech of Wise, 6.
} 
Wise's political maneuvering and defense of democratic reform helped free the logjam that had stalled the convention's progress. In the weeks following Wise's speech, eastern ranks crumbled as delegates from Lynchburg, Norfolk, and Richmond recanted their support of the "mixed basis." 79 A final bill concerning representation received delegates' approval in late May 1851. In the House of Delegates, the West received eighty-two of the 150 seats, while the East obtained thirty of the fifty seats in the Senate. The bill also stipulated that the General Assembly would revisit apportionment in 1865 and, if members could not reach agreement on how representation should calculated, four options would be voted on by the public. ${ }^{80}$

With representation settled, delegates quickly agreed on other constitutional issues. Unlike during the previous constitutional convention, the expansion of suffrage met little resistance as Whigs and Democrats across the state sought to increase their electorate. Though some conservatives advocated some form of property ownership for voting privileges, their calls appeased few and, by July, delegates passed universal male suffrage. ${ }^{81}$ Delegates also increased the number of popularly elected offices, including that of the governor, lieutenant governor, attorney general, and members of the Board of Public Works. In an effort to reform the county court system, the constitution empowered residents to elect all local and appellate judges and

\footnotetext{
${ }^{79}$ Link, Roots of Secession, 20-25.

${ }^{80}$ Link, Roots of Secession, 22-23 and Tarter, Grandees of Government, 192. The final bill stipulated that each house construct its own plan for apportionment, and then give them to the governor for ratification by the people. If the legislature was unable to agree on a proposal, residents would have their choice of four different options: suffrage basis for both houses, the mixed basis for both houses, suffrage for the House and taxation in the Senate, and suffrage for the House and mixed basis in the Senate. If one of these proposals failed to garner a majority, then the top two would be placed in a runoff.

${ }^{81}$ Curtis, Jefferson's Freeholders, 193 and Gaines, Jr., "The Virginia Constitutional Convention of 1850-51,” 245247. It should be noted that voters had to pay a $\$ 200$ capitation tax, half of which would go to support public education in the state. Though the majority of delegates rejected property qualifications, a few attempted to retain them. Richmond Delegate Hector Davis argued that only taxpayers and those who held at least \$25 worth of land should be allowed to vote. Fairfax Delegate William Edwards believed that only those who were current with their state and county taxes should be allowed to cast a vote. The final bill allowed all white males above the age of twenty-one, and who had lived in the state for two years and their district for twelve months preceding an election to vote. Restrictions were placed on paupers, the mentally handicap, and non-commissioned military personnel.
} 
justices of the peace. ${ }^{82}$ These measures, exclaimed the Wellsburg Weekly Herald, illustrated the "grand advance" of "liberal principles" in the state, and an important triumph of democratic reform over antiquated aristocratic elements. ${ }^{83}$

This constitutional triumph of democratic reform also strengthened the institution of slavery. The 1851 Constitution required that any emancipated African American slave would "forfeit their freedom" and be reenslaved if they remained in the state beyond one year. ${ }^{84}$ The new constitution also empowered the General Assembly to "impose... restrictions and conditions...on the power of slave-owners to emancipate their slaves," curtailing a slaveholder's prerogative while increasing the power of the General Assembly to legislate such actions. ${ }^{85}$ Section 21 of the Constitution prohibited the General Assembly from "emancipat[ing] any slave, or the descendant of any slave." ${ }^{" 86}$ Proslavery advocates found much to celebrate in such clauses. Virginia's government and elected officials would be constitutionally obligated to protect slavery, ensuring that whatever future conflicts arose concerning African American bondage, Virginians would be compelled to support slavery.

Slaveholders also received extra constitutional protection concerning taxation. The 1851 Constitution included an ad valorem system of tax assessment where all forms of property would be taxed "in proportion to its value." Property in slaves, however, was exempt from that assessment. ${ }^{87}$ Rather, slaves twelve years and older "shall be assessed with a tax equal to and

\footnotetext{
${ }^{82}$ Tarter, Grandees of Government, 190 and Curtis, Jefferson's Freeholders, 194.

${ }^{83}$ Wellsburg Weekly Herald, August 1, 1851, 2.

${ }^{84}$ Virginia Constitution, 1851, art. IV, sec. 19 [http://vagovernmentmatters.org/archive/files/vaconstitution1851_ded45111de.pdf] [accessed 14 April 2015].

${ }^{85}$ Curtis, Jefferson's Freeholders, 228 and Virginia Constitution, 1851, art. IV, sec. 20 [http://vagovernmentmatters.org/archive/files/vaconstitution1851_ded45111de.pdf] [accessed 14 April 2015]. This section also included a clause supporting the passage of laws designed to remove the "free negro population."

${ }^{86}$ Virginia Constitution, 1851, art. IV, sec. 21 [http://vagovernmentmatters.org/archive/files/vaconstitution1851_ded45111de.pdf] [accessed 14 April 2015].

${ }^{87}$ Virginia Constitution, 1851, art. IV, sec. 22

[http://vagovernmentmatters.org/archive/files/vaconstitution1851_ded45111de.pdf] [accessed 14 April 2015].
} 
not exceeding...three hundred dollars." Slaves under twelve "shall not be subject to taxation." 88 These articles, similar to proposals offered by Henry Wise, ensured that slaveholders would be protected from market changes and hostile nonslaveholders wielding legislative power. ${ }^{89}$ The full weight of the new state constitution supported slavery and slaveholders' rights while simultaneously inaugurating democratic reform. The democratic revolution of 1851 signaled Virginians' overwhelming commitment to slavery.

Northwestern Virginians passionately defended and supported the new constitution. ${ }^{90}$ One resident exclaimed that the "West ought to be satisfied" with the new constitution "for it is more than I ever expected could be obtained." "[W]e will have a very democratic constitution," he concluded. ${ }^{91}$ The Wellsburg Weekly Herald viewed the new "liberal" constitution with "entire satisfaction" and believed it "will pass without much opposition." Now the "poor man...can stand on equal platform at the polls, with his purse proud neighbor," and obtaining political office "must be gained by other means than buying or courting favor at Richmond." 92 Any faults in the new constitution were "immaterial." If "Virginians cannot thrive under" the new constitution, the Herald concluded, "their case is hopeless."93 The Kanawha Republican, meanwhile, considered the tax concessions as "a wrong and an injustice." But the measures

\footnotetext{
${ }^{88}$ Virginia Constitution, 1851, art. IV, sec. 23 [http://vagovernmentmatters.org/archive/files/vaconstitution1851_ded45111de.pdf] [accessed 14 April 2015]. ${ }^{89}$ Curtis, Jefferson's Freeholders, 226-227.

${ }^{90}$ Northwesterners' support for the new constitution was likewise manifest through their votes for the new constitution. The entire state posted a large majority in favor of the new constitution, 75, 748 for and 11,060 against. Efforts to track down county totals have proven fruitless so far. Given the large majority in favor of the constitution and that most of the opposing votes came from eastern Virginians, Northwestern voters strongly supported the constitution's adoption. David L. Pulliam, The Constitutional Conventions of Virginia: From the Founding of the Commonwealth to the Present Time (Richmond: J.T. West, 1901), 98.

${ }^{91}$ E.D. Wilson to Gideon D. Camden, 27 June 1851, Gideon D. Camden Collection, A\&M 122, Box 2, Folder April 1851 to July 1851 , WVRHC.

${ }^{92}$ Wellsburg Weekly Herald, August 15, 1851, 3.

${ }^{93}$ Wellsburg Weekly Herald, August 8, 1851, 2. The two features the newspaper objected to were the continuation of viva voce and the "arrangement of representative apportionment." Still, the paper threw its full weight behind the constitution's ratification.
} 
were part of a larger "compromise" adopted by Virginians "for the sake of peace and the preservation of the unity of the State." The newspaper called upon "all people of all sections [to] live up to it in good faith." ${ }^{\text {94 }}$ Wirt County farmer Aaron Ruble celebrated the new constitution. He found the new constitution "much better than... anticipated," and believed that it demonstrated the triumph of "Human wrights \& Republican Principals." The "boys of the Western Mountains" had achieved a tremendous victory, he exclaimed. ${ }^{95}$

For more than a decade prior to this constitutional convention, northwestern residents pledged their support for extra safeguards for slaveholders in union with democratic reform. The new constitution satisfied both arrangements. Northwesterners celebrated the new constitution's democratic reforms, notably universal male suffrage, the direct election of government officials, a more equally apportioned state legislature, a reformation of the county court system, and the funding of public education. All of these democratic initiatives vested political power in "the people," a marked departure from what many residents claimed to be the aristocratic and archaic 1830 Constitution. But now "the people" had to protect slavery through the ballot box, supporting politicians who pledged to defend slavery and assailing those who threatened the institution. Further, the actions of elected representatives would be under intense scrutiny, lest any politician waver on their commitment to African American bondage. This heightened defense of slavery reflected its importance in the state's body politic. Virginians situated slavery at the core of their political and constitutional system because slavery now officially provided political independence and protected liberty for white men. This "whitening" of the political process also cast race as the only demarcation between freedom and bondage, further increasing

\footnotetext{
${ }^{94}$ Kanawha Republican, March 17, 1852, 2.

${ }^{95}$ Aaron Ruble to Gideon D. Camden, 13 August 1851, Gideon D. Camden Collection, A\&M 122, Box 3, Folder August 1851 to December 1851, WVRHC and 1850 U.S. Federal Census, District 70, Wirt, Virginia; Roll: M432_981; Page: 78B; Image: 160 [Ancestry.com] [accessed 14 April 2015].
} 
the political stakes. Now defending whiteness meant defending slavery, a dynamic that few in the Northwest opposed.

The euphoria surrounding the new constitution's adoption carried over into the state's first popularly-elected gubernatorial contest in December 1851. Previous governors, chosen by the state legislature, protected the "slaveholding counties" from majoritarian power, one conservative confessed. ${ }^{96}$ John Carlile, though, characterized the governor as a "Creature of the Legislature" who remained "indebted" to legislators while he supposedly represented and served all Virginians. ${ }^{97}$ Now, with the adoption of universal male suffrage, governors appealed directly to voters, championing their causes and defending their interests. While the "politics of slavery" existed prior to 1851, this southern brand of politics intensified post-convention, as political candidates continually reaffirmed their fealty to slavery and support for slaveholders' rights. These appeals represented more than protecting slavery; they also reflected candidates' promises to protect white men's political independence.

Before the constitution's ratification in October 1851, Democrats and Whigs had already chosen their respective candidates for governor. Meeting in September in the Shenandoah Valley town of Staunton, Democrats chose politician and farmer Joseph Johnson from Harrison County. Whigs, convening in Charlottesville, selected Kanawha County lawyer George W. Summers. ${ }^{98}$ Both gubernatorial candidates were slaveholders, with Johnson owning six slaves and Summers five. ${ }^{99}$ As the campaign unfolded, Summers initially stressed traditional Whig

\footnotetext{
${ }^{96}$ Views of the Constitution, 47.

${ }^{97}$ Virginia Reform Convention, 118.

${ }^{98}$ Link, Roots of Secession, 77.

${ }^{99} 1850$ U.S. Federal Census - Slave Schedules, Harrison County, Virginia [Ancestry.com] [accessed 15 April 2015] and 1850 U.S. Federal Census - Slave Schedules, Kanawha County, Virginia [Ancestry.com] [accessed 15 April 2015].
} 
economic policies, notably the creation of state-funded internal improvements and protective tariffs. Slavery, though, quickly trumped these issues and dominated the contest.

In 1832, as a state representative in the House of Delegates, Summers, then a nonslaveholder, announced his support for some form of emancipation. Further, he echoed Thomas Jefferson's assertions that owning slaves corrupted a slaveholders' moral compass. While such sentiments may have been permissible in the immediate post-Nat Turner context, in 1851 they appeared subversive, dangerous, and hostile to African American bondage. Eastern Democrats assailed Summers on his supposed infidelity, accusing him of abolitionism. One Charleston supporter of Summers noted that eastern Democrats "are trying to injure him...by republishing his speech in 1832." He remained optimistic that such efforts "will fail.",100 Another supporter decried eastern Virginians who attempted to brand Summers as an abolitionist. These attacks sought "to prove that Western men were not then, are not now, and ought not hereafter to be trusted on the subject of slavery." All western Virginians should "resent the insult at once" because, as "sons" of the same Commonwealth, they had remained "true to Virginia." Summers manifested that loyalty. The "Western masses" supported Summers because of his "loyal and unflinching" advocacy of "Western interests and rights" but also because of his devotion "to every interest of all Virginians," including slavery. Easterners' characterization of Summers as an abolitionist was ludicrous. "If he cannot be trusted on the subject of slavery," a partisan declared, "neither can the whole West."101

Confronted with such accusations, Summers defended his position on slavery. Summers considered the charge of abolitionism "ridiculous" and solely calculated to produce "false

\footnotetext{
${ }^{100}$ N. Fitzhugh to Waitman T. Willey, 30 October 1851, Charles H. Ambler Collection, A\&M 122, Box 10, Folder 3 , item 144, WVRHC.

${ }^{101}$ Hugh W. Sheffey to Waitman T. Willey, 11 November 1851, Charles H. Ambler Collection, A\&M 122, Box 10, Folder 3, item 145, WVRHC. [emphasis in original]
} 
apprehension" among voters. "I am a slaveholder," he declared, residing in the largest slaveholding county west of the Alleghenies and strongly opposed to "all and every scheme" that could "affect the security of slave property." Summers also reminded voters that he supported the constitutional provision denying the state legislature authority to emancipate slaves. The true threat to slavery, he inferred, was his opponent. Joseph Johnson "lives in a part of the State having less interest in that property" than other regions, and Summers was unsure if Johnson owned slaves. Further, Johnson's former home state of New York welcomed abolitionists and helped escaped slaves flee to Canada. Summers suggested that Democrats carefully scrutinize their candidate before casting aspersions on him. ${ }^{102}$ Despite the "mad-dog cry of abolition" from eastern "blood hounds," Summers remained confident in his chances, and encouraged western Virginians to "stand" against these baseless accusations. For the accusations against Summers' fidelity were more than partisan attacks; rather, they represented "an attack upon the whole West," and all westerners needed to respond. ${ }^{103}$

For his part, Johnson, who had served as governor under the previous constitution, welcomed the work of those Democratic "blood hounds." By December 1851, doubt surfaced among Whigs about turnout for their candidate. In Parkersburg, Peter G. Van Winkle lamented that though he expected a majority for Summers in the traditionally Whiggish city, "nobody here knows and very few... will venture a guess" at that figure. The attacks had taken "a slice...off here and another there," leaving little hope that Summers would emerge victorious. Though

\footnotetext{
${ }^{102}$ Martinsburg Gazette, November 11, 1851, 2.

${ }^{103}$ George W. Summers to Waitman T. Willey, 25 November 1851, Charles H. Ambler Collection, A\&M 122, Box 10, Folder 3, item 146, WVRHC.
} 
Whigs pledged to "do our best," the accusations against Summers proved too difficult for his candidacy to withstand. ${ }^{104}$

Johnson won Virginia's first popularly-elected gubernatorial election by a comfortable margin. Summers received reduced Whig majorities in typical eastern Whig strongholds in the Piedmont and Tidewater, as the charges of abolitionism resulted in "a prodegeous falling away" amongst once stalwart Whigs. In the Northwest, party lines generally held sway. Whig counties in the region, particularly Ohio and Wood, generated large majorities for Summers while traditionally Democratic counties, including Monongalia, Preston, Marion, and Harrison, supported Johnson. ${ }^{105}$ Northwesterners, honed in the practice of the "politics of slavery," showed little of the violent electoral swings that could have unfolded with the inauguration of universal male suffrage. Though defeated Whigs believed that "the new voters were generally on the democratic side," northwestern voters reflected the continuation of entrenched partisan affiliation. ${ }^{106}$ A few voters probably moved from one party to another, but the majority of voters remained loyal to their party. Whigs believed their candidate would defend slavery while Democrats professed the same about their nominee. The two-party system in the Northwest proved resilient and dynamic, permitting broad participation in the post-convention era while still manifesting the "politics of slavery."

But dissatisfaction with the fusion of slavery and electoral politics appeared to take an aggressive turn following the 1851 gubernatorial election. In early 1853, Brooke County

\footnotetext{
${ }^{104}$ Peter G. Van Winkle to Gideon D. Camden, 5 December 1851, Gideon D. Camden Collection, A\&M 1199, Box 3, Folder August 1851 to December 1851, WVRHC.

${ }^{105}$ Cooper's Clarksburg Register, January 28, 1852, 3.

${ }^{106}$ John Allen to Gideon D. Camden, 9 January 1852, Gideon D. Camden Collection, A\&M 1199, Box 3, Folder January 1852 to April 1852, WVRHC. Peter G. Van Winkle also suggested that new voters introduced an unknown variable into the electoral system, suggesting that their inclusion could prove hurtful for Whig candidates. See Peter G. Van Winkle to Gideon D. Camden, 5 December 1851, Gideon D. Camden Collection, A\&M 1199, Box 3, Folder August 1851 to December 1851, WVRHC.
} 
residents convened to discuss annexation to Pennsylvania. Historians have often interpreted this event as a denunciation of the "politics of slavery" and a harbinger of future dismemberment. ${ }^{107}$ The causes of this meeting, though, were more complex. Residents lamented their "dependence upon Wheeling," decrying the favoritism bestowed by Richmond while Wellsburg languished. Wellsburg city leaders predicted that their "unfortunate geographical position" would "become worse and worse as Wheeling" grew "more influential and populous," cementing its status as the Northwest's lodestar. ${ }^{108}$ The state legislature deserved partial blame for refusing to adjudicate this conflict. The "palpable oppression" exhibited by the General Assembly, notably in its lethargic pace in granting railroad charters, incensed Brooke County residents. As Ken FonesWolf has noted, many of Wheeling's economic, social, and political elite cultivated relationships with Richmond politicians, generating ties that bound the two cities together while other northwestern cities and towns suffered. ${ }^{109}$ Wellsburg represented one of those casualties. Wheeling residents jeered Wellsburg's secession movement. The editors of the Wheeling Daily Intelligencer mocked the "proceedings of the Wellsburg night meetings," where a few residents clandestinely convened to express their misguided frustration. Such meetings occurred under the cover of darkness because of Brooke County residents' strong opposition to

\footnotetext{
${ }^{107}$ William Link argues that this meeting, along with another held in 1856, reflected "[p]anhandle disenchantment" and that the meetings enjoyed wide popularity in the Northwest. Link, Roots of Secession, 160.

${ }^{108}$ Wellsburg Weekly Herald, March 18, 1853, 2.

${ }^{109}$ Ken Fones-Wolf, “"Traitors in Wheeling': Secessionism in an Appalachian Unionist City,” Journal of Appalachian Studies, 13, no. 1 and 2 (Spring and Fall, 2007): 75-95. The economic ties between northwestern industries and southern markets also likely fostered important bonds between northwestern residents and slaveholders across the Deep South. Wheeling nail manufacturers often sold their product in southern markets, most likely St. Louis or New Orleans, where they could be purchased by slaveholders and planters. As the Wheeling Daily Intelligencer maintained, Wheeling should "take up the interest of the planter as their own," specifically in regards to the cotton trade. Wheeling Daily Intelligencer, May 21, 1853, 2. Also see Wheeling Daily Intelligencer, September 17, 1852, 3 and Wheeling Daily Intelligencer, May 31, 1853, 3. A cotton manufacturer in Wellsburg "shipped large quantities of it to the south and southwest" during the 1840s and $1850 \mathrm{~s}$, furthering the ties of this northwestern town with slaveholders and planters. Jacob, Brooke County, 67. This economic relationship mirrors a similar one John Inscoe interprets in the mountains of western North Carolina. See John C. Inscoe, Mountain Masters, Slavery, and the Sectional Crisis in Western North Carolina (Knoxville: University of Tennessee Press, 1989).
} 
dismemberment. ${ }^{110}$ Indeed, the Intelligencer doubted the " "natural kinship"” between the Panhandle and Pennsylvania, as suggested by some Wellsburg politicians. Though the Panhandle shared a similar geographic position with Pennsylvania, Wellsburg residents held more in common with Virginians than residents of the Keystone State. ${ }^{111}$ The editors of the Intelligencer were correct. Despite the animosity expressed by Wellsburg residents, many looked toward possible dismemberment with sadness and "regret," not alacrity or hopefulness. ${ }^{112}$ Yet again, those advocating for a division of the state were few and isolated, often advocating dismemberment for other reasons that simply escaping from the state's slaveholding regime.

A division of the state, though, according to one historian, remained in the forefront of politics as dramatic demographic changes accelerated during the late 1840 s and 1850 s. ${ }^{113}$ German immigrants, fleeing the failed 1848 Revolution and attracted by the Northwest's growing industrial sector, arrived in large numbers in the late 1840s and early 1850s. ${ }^{114}$ Most of these immigrants spoke neither English nor the language of slavery. During the previous constitutional convention, eastern delegates worried that these German immigrants, once enfranchised, could elect politicians apathetic or hostile to the state's slaveholding interest. The rituals and public political displays signaled German immigrants' presence and demonstrated their political fitness. ${ }^{115}$ But could these immigrants be trusted on the issue of slavery?

\footnotetext{
110 Wheeling Daily Intelligencer, April 19, 1853, 2.

111 Wheeling Daily Intelligencer, August 13, 1853, 2.

112 Wellsburg Weekly Herald, March 18, 1853, 2.

${ }^{113}$ Link, "This Bastard New Virginia,"” 37-56. This conclusion reflects one of Link's previous arguments in Roots of Secession, where he argues that the large number of Irish and German immigrants in Richmond and Petersburg threatened to destabilize slavery and radically alter electoral politics against the interest of slaveholders. Secession, therefore, represented an attempt to preserve slaveholders' control over not only their chattel but the political system that protected their property rights from nonslaveholders.

${ }^{114}$ Ken Fones-Wolf, "Caught Between Revolutions: Wheeling Germans in the Civil War Era," in Transnational West Virginia: Ethnic Communities and Economic Change, 1840-1940, ed. Ken Fones-Wolf and Ronald L. Lewis (Morgantown: West Virginia University Press, 2002), 19-47 and William M. Seaman, "The Germans of Wheeling: Part One," Upper Ohio Valley Historical Review, 3, no. 2 (Spring-Summer 1979): 21-27.

${ }^{115}$ For examples, see Wheeling Daily Intelligencer, July 6, 1853, 3 and Wheeling Intelligencer, May 23, $1854,3$.
} 
Some Germans attempted to integrate themselves within Virginia's slaveholding culture by defending slavery and denying charges that they harbored antislavery or abolitionist sentiments. In March 1854, Germans in Wheeling gathered to discuss recent legislative action on licensing and temperance. After a speech by Democratic Congressman Sherrard Clemens, gatherers passed a series of resolutions. The attempt by "unprincipled demagogues" to "drag the temperance question" into the political arena reflected the machinations of "Northern fanaticism" who sought to disturb national and state tranquility. These machinations could be clearly seen in the efforts of J.E. Wharton, a Wheeling newspaper editor, who published articles appearing to condemn slavery. Rather than allow such inflammatory messages on slavery to slander the Northwest, these Germans immigrants sought to "condemn the traitor to our laws, and abhor the treason." Wheeling Germans "utterly disclaim the slightest sympathy of feeling" with any article attacking slavery, considering such positions as "not only disloyal to the city and state, but DISGRACEFUL to both." As proud Virginians, these Wheeling Germans denounced any attempt to undermine the institution that supported their political freedom in their new homeland. ${ }^{116}$

The role of Wheeling Germans in supporting slavery extended beyond assailing those who spoke against the peculiar institution within the state's borders. "[A]s a border people," these immigrants considered themselves sentinels on the state's "outpost," offering to defend the "cherished institutions of the State." These men pledged their support in "repressing the invading spirit of Northern fanaticism, in whatever shape presented...by foes without, or less honorable...[and] more insidious and cowardly, foes within.” Wheeling Germans' fealty toward slavery carried over into their support of Virginia. Though rumors of division occasionally surfaced in the region, "we stand by the ancient, faith, policy, and renown of Virginia." "[W]e

${ }^{116}$ Wheeling Intelligencer, March 25, 1854, 2. [emphasis in original] 
will indignantly repel any attempt to distract and divide" Virginians "or to array any one portion of her people against the other upon questions of domestic policy or institution." Rather than actively pursue dismemberment or attack slavery, these Wheeling Germans supported African American bondage, defended the institution from any and all threats, and pledged their fealty to Virginia. Though some eastern planters continued to express fear about this growing new electorate, these immigrants sought to dispel such notions. ${ }^{117}$

Expressions of fealty toward slavery and Virginia, including those articulated by Wheeling Germans, reflected a larger phenomenon unfolding across the Northwest. This commitment to African American bondage and the state reflected the widespread belief of the inextricable and intimate connection between the two institutions. With slavery interlaced through the state's constitutional and political structures and functions, northwestern residents' defense of slavery illustrated their patriotism; their allegiance to the state likewise reflected their attachment to slavery. Residents manifested the arguments championed by Leigh, Dew, and Upshur, who had emphasized the close relationship between the state government and slavery. The voices in the Northwest that questioned this important relationship, such as J.E. Wharton, were few and isolated, and often invited censure from the public. Northwesterners' remained committed to the state and to slavery.

In early January 1853, the Ohio County Court heard the case of a runaway female slave. The slave had escaped to Ohio with the aid of a free African American in Wheeling, who authorities later captured and detained. The court found the slave guilty of absconding from her owner and sentenced her to two years in jail. The justice delivered by the court, the Wheeling Daily Intelligencer proudly announced, demonstrated the Northwest's fealty on slavery and

${ }^{117}$ Wheeling Daily Intelligencer, March 25, 1854, 2. 
slaveholders' rights. The "people of the Northwest are behind none in their fidelity to the laws designed to protect the institutions of Virginia," the Intelligencer declared. Though eastern legislators and slaveholders questioned northwesterners' position on slavery, the court's decision reflected residents' perspective on African American bondage. Northwesterners, "though not slave owners," remained "true to the interests of those of Virginia's citizens who were," and would fight for the right of fellow Virginians to own slaves. Further, residents "opposed...Abolitionism and Free Soil agitation, as any citizens of the State." "[N]o one" in the region opposed the court's decision because northwesterners understood the fundamental importance of the master-slave relationship. The master-slave relationship needed "to be protected and enforced at all hazzards" because it was "part and parcel of the law of the land." Indeed, because slavery and the master-slave relationship represented the cornerstone of the state government, northwesterners would punish "to the utmost rigor of the law, all who seek to interfere" with the peculiar institution. ${ }^{118}$

Those who sought to disrupt the master-slave relationship, notably abolitionists, drew ire and elicited censure from Northwest residents. Northwesterners ridiculed abolitionists' promotion of social and racial equality, perceiving in such ill-fated efforts a baseless attempt to destabilize the country and part of a larger program designed to overturn established hierarchies. The Wheeling paper mocked an "anti-Slavery Convention" held in Cincinnati that welcomed "Infidels, Negroes, and women in short coats and breeches," a motley crew of men and women seeking to overturn patriarchy and racial hierarchy. The differences between abolitionists and anti-slavery advocates mattered little; their endgame appeared identical. ${ }^{119}$ A southwest Virginian maintained that southerners had "rescued [African Americans] from barbarity,

\footnotetext{
${ }^{118}$ Wheeling Daily Intelligencer, January 8, 1853, 2.

119 Wheeling Daily Intelligencer, April 18, 1854, 2.
} 
idolitory, cannibalism, and brutality," Christianizing and civilizing African Americans. But abolitionists" dogma of "Uncle Tomism" threatened to "shake the world and cause civilization to retrograde." ${ }^{120}$ In Morgantown, the editor of the Monongalia Mirror mocked the nuptials of an African American man and the daughter of a white abolitionist. The daughter "had been bro't up an abolitionist," taught to "look upon the negro race with...pity and charity," and witnessed the reception of African Americans into her household "on terms of perfect equality and affection." Though the father objected to the marriage, the two stole away, married, and were now expecting. The Mirror relished in the irony of the situation. "The fool is caught in his folly," the newspaper proclaimed, and soon the abolitionist would be "saluted by the sweet lisp of half a dozen little niggers." Abolitionism was a farcical and dangerous doctrine, northwesterners believed, designed only to overturn established hierarchies and threaten national stability. ${ }^{121}$ Though some northern abolitionists characterized the Panhandle as fertile ground for proselytizing, residents denied such baseless characterizations. "[A]re the people Wheeling Abolitionists or free soilers," the Wheeling Daily Intelligencer rhetorically asked. "[O]r are they Virginians and Southerners in sentiments and interests?" 222 "Our sons of the soil are true as steel to their Alma Mater, the dear old Commonwealth, and to the institutions of their forefathers," the editors maintained. Defending the fidelity of Panhandle residents' seemed unnecessary because of the widespread acceptance of slavery and support for Virginia. Even "most of our adopted brethren have the good sense to respect" slaveholders' rights, slavery, and the institutions of the state. ${ }^{123}$ Followers of these dangerous “ "isms' of the North...burnt the Bible, the Constitution of the United States and the Declaration of Independence, because they sanctioned the institution of

\footnotetext{
${ }^{120}$ Wheeling Daily Intelligencer, May 25, 1853, 2.

${ }^{121}$ Monongalia Mirror, May 14, 1853, 1.

122 Wheeling Daily Intelligencer, March 13, 1854, 2.

${ }^{123}$ Wheeling Intelligencer, April 1, 1854, 2.
} 
slavery." Northwesterners denounced such actions. ${ }^{124}$ Summarizing the position of its citizens, the Wheeling Daily Intelligencer proudly proclaimed that they "have taken a firm stand against Abolitionism and kindred fanaticism." 125 These denunciations of "isms" and "ists" reflected a shared commitment among southern and northern conservatives to marginalize and extinguish ideologies that threatened established hierarchies. ${ }^{126}$ Further, these denunciations also signaled northwesterners' widespread acceptance of established and dominant hierarchies, notably slavery and patriarchy. Northwesterners' felt neither isolated from the state nor indifferent to its institutions; rather, residents closely identified with other Virginians and supported the state's institutions.

The threat of "isms" or "ists" infiltrating Virginia's electoral politics appeared manifest in the 1855 gubernatorial election. Democrats selected Eastern Shore politician and planter Henry A. Wise as their candidate for governor, the "most popular eastern man in the west," according to a Wellsburg newspaper. ${ }^{127}$ His supporters argued that his defense of democratic reforms and increased protection for slavery during the constitutional convention endeared him to yeomen across the state who would help propel him to victory. A Taylor County resident considered "the name of Mr. Wise... a cherish[ed] word in every cabin in W. Virginia," and "hope[d]...to signalise my gratitude in some more tangible form." ${ }^{128}$ Before Wise's official nomination, the Cooper's Clarksburg Register supported his candidacy, reminding readers of his important work in the previous convention. Northwesterners owed Wise their "grateful remembrance" as he "contributed...in overthrowing the odious 'mixed basis"” and helped secure northwesterners'

\footnotetext{
124 Weston Herald, April 11, 1855, 2.

125 Wheeling Intelligencer, April 21, 1854, 2.

${ }^{126}$ Michael F. Conlin, "The Dangerous Isms and Fanatical Ists: Antebellum Conservatives in the South and North Confront the Modernity Conspiracy," Journal of the Civil War Era, 4, no. 2 (June 2014): 205-233.

${ }^{127}$ Wellsburg Weekly Herald, August 18, 1854, 2.

128 John G. Burdett to Waitman T. Willey, 28 April 1851, Charles H. Ambler Collection, A\&M 122, Box 10, Folder 3, item 138, WVRHC.
} 
political representation. ${ }^{129}$ At a Democratic meeting in Harrison County, residents passed two resolutions extolling Wise's efforts during the convention. Wise was the "able and fearless defender of equal rights and equal laws" who also manifested a "sincere devotion...to the interests and institutions of the South." Harrison County residents pledged their full support. ${ }^{130}$

Whigs, though, faced an existential crisis. Whigs' failed attempts to court immigrants in the early 1850s alienated nativist voters in the North and upper South, including Virginia. By 1854, the party fractured, unable to contain the sectional discord arising from the KansasNebraska Act. Fragments of the party (combined with some alienated Democrats) lived on in the American, or Know Nothing, Party. The Know Nothing Party, built upon an anti-immigrant platform, purportedly told its followers to claim that they "know nothing" about the organization's functions. Followers also gained the name "Sam," a derivative of "Uncle Sam" and a reflection of the party's nativist ideology. ${ }^{131}$

By the middle of the 1850s, Know Nothings constituted a prominent political party and a threat to Democratic hegemony in Virginia and the South. Know Nothings enjoyed electoral success in Fredericksburg, Norfolk, Lynchburg, and Portsmouth, and an increasing presence in Wheeling, Charleston, and Lewisburg on the western side of the Alleghenies. ${ }^{132}$ One Wheeling resident approved the party's opposition to "political popery," a stance that opposed the rituals

${ }^{129}$ Cooper's Clarksburg Register, August 16, 1854, 2.

${ }^{130}$ Cooper's Clarksburg Register, March 14, 1855, 2. Conversely, Wise and his supporters broadcasted his opponents' stance on constitutional reform throughout the campaign. Wise labeled Flournoy a "Mixed Basis" supporter, and the Know Nothing candidate for Attorney General John M. Patton an "anti-reformer...agt. popular election - agt. extension of suffrage - for old county court - mixed basis \& c." Henry Wise to Jonathan M. Bennett, 23 March 1855, Jonathan M. Bennett Collection, A\&M 32, Box 11, item 3541, WVRHC. See also Weston Herald, April 4, 1855, 2.

${ }^{131}$ Wilentz, Rise of American Democracy, 679-682. The American Party emerged during the 1840s in response to the influx of European immigrants fleeing political revolutions and famines plaguing Europe. The influx of immigrants from Europe - many of them Irish Catholics - particularly worried Know Nothings because of their Catholic religion and predilection for alcohol consumption.

${ }^{132}$ Link, Roots of Secession, 122. 
used by the Democratic Party to secure political power. ${ }^{133}$ The party's maturation in Virginia reflected the concomitant increase in the number of foreign-born residents within the state and the Northwest. Approximately thirty-five thousand foreign-born residents called Virginia home in 1850, ranking it as one of the highest totals among slaveholding states. Most immigrants settled in cities such as Richmond, Petersburg, and Wheeling. Northwestern counties, notably Marshall and Ohio, boasted some of the higher figures of foreign-born residents in the state. ${ }^{134}$ Democrats welcomed immigrants (and their voting power), believing that their arrival in the United States reaffirmed the nation's exceptional status as a bastion of liberty and freedom. But many residents in the Northwest worried that these immigrants, many of whom were Catholic, would maintain their allegiance to the pope and not the president. Immigrants looked, spoke, and acted differently than Anglo-Americans, increasing concerns that immigrants could upset established hierarchies. This fear provided fertile ground for the Know Nothings to build their grassroots campaign.

While Know Nothings could deliver a nativist message, their secrecy and party procedures garnered sharp criticism. This "subterranean organization" operated clandestinely and avoided "the free and public discussion of all political questions" that characterized American politics, a Clarksburg newspaper charged. ${ }^{135}$ Secret oaths, night meetings, guarded members, and refusing to debate appeared to validate Democrats' accusations that Know Nothings constituted a tangible threat to political stability. Further, this secrecy that shrouded

\footnotetext{
${ }^{133}$ T.G. Gally to Waitman T. Willey, 12 August 1854, Charles H. Ambler Collection, A\&M 122, Box 10, Folder 4, item 187, WVRHC. [emphasis in original]

${ }^{134}$ Of the slaveholding states, only Texas, Louisiana, Kentucky, and Maryland held more foreign-born residents. For the northwestern Virginia counties mentioned above, Marshall was home to 957 foreigners and Ohio had 5,510. Those figures rank seventh and second, respectively, among Virginia counties in 1860. University of Virginia Geospatial and Statistical Data Center: Historical Census Browser [http://mapserver.lib.virginia.edu/php/newlong3.php] [accessed 23 April 2013].

${ }^{135}$ Cooper's Clarksburg Register, August 23, 1854, 2 and Cooper's Clarksburg Register, April 26, 1854, 2.
} 
the party caused some residents to question the manhood of its members. "[A]bolitionists and disunionists," though preachers of "treasonable" doctrines, were "sufficiently honest and manly to boldly avow their principles." Know Nothings' secrecy made members "excessively modest" and inculcated a "conscious weakness and unworthyness" among its followers. ${ }^{136}$ Indeed, some Democrats applauded Abolitionists' "manliness" to maintain their stance and combat Democrats; Know Nothings, though, skirted such conflict. ${ }^{137}$ "In Virginia men are manly," the Morgantown Telegraph declared; "they are not sneaks."138

Most Know Nothings expressed little concern about their party's procedures, but the issue of slavery proved nagging and difficult to navigate. Their candidate for governor in 1855 , Thomas S. Flournoy, a former Whig congressman, encountered this sharp criticism. The Richmond Enquirer uncovered a speech given by Flournoy that caused some Virginians to question his position on slavery. "No country can be prosperous with a slave population," Flournoy stated, an argument that closely paralleled abolitionist rhetoric. ${ }^{139}$ In an effort to burnish their candidates' proslavery credentials, Know Nothings across the state maintained that their nominees would protect the interests of slaveholders, notably by supporting the Fugitive Slave Act, the Kansas-Nebraska Act of 1854, and popular sovereignty in the territories. Know Nothings held "sound views of State policy," notably on slavery, members declared. ${ }^{140}$ In Morgantown, the American Union, one of the few Know Nothing newspapers in the region, defended the disenfranchisement of foreigners and Catholics because of the threat they posed to slavery. Such men believed that "ecclesiastical” authority was "superior to...civil power,"

\footnotetext{
${ }^{136}$ Cooper's Clarksburg Register, August 30, 1854, 2.

${ }^{137}$ Cooper's Clarksburg Register, February 7, 1855, 2.

${ }^{138}$ Morgantown Telegraph, May 31, 1855, 2.

${ }^{139}$ Richmond Enquirer, April 2, 1855, quoted in Craig Simpson, A Good Southerner: The Life of Henry A. Wise of Virginia (Chapel Hill: The University of North Carolina Press, 1985), 110.

140 Wheeling Daily Intelligencer, March 19, 1855, 2.
} 
regarding their allegiance to the pope as superior to their allegiance to Virginia and its institutions. Foreigners" "mistaken notions of Liberty, and more erroneous ideas of their Constitutional prerogatives as citizens" invariably led them to demand slavery's abolition, joining with other "mad-cap factionists...in a war upon the peculiar institutions of the South."141 By restricting foreigners' political representation and power, Know Nothings sought to halt the spread of abolitionism while demonstrating their fealty to slavery.

These public stances on slavery coincided with Know Nothings' attempts to disarm Democrats' accusations about their unsafe position on the institution. Many western Know Nothings mocked attempts by Democrats to label Americans as "traitors" to Virginia institutions, including slavery. Know Nothings sought neither the abolition of slavery nor the overthrow of established hierarchies; rather, they sought to purify the electoral system from Democratic corruption and manipulation. ${ }^{142}$ A Parkersburg newspaper maintained that Know Nothings' candidate for lieutenant governor candidate, James M.H. Beale of Mason County, "avows and entertains the same views on Slavery" as those found in "the whole district, without distinction of party.” Indeed, “all Western Virginia" shared Beale's proslavery convictions. ${ }^{143}$ In Ohio County, Know Nothings denounced Democrats' fear mongering techniques. Democrats resorted to "detraction and misrepresentation, and falsehood upon falsehood" in order "to injure [Know Nothings] in the eyes of the people."144 "Sundry rumors" designed to cast doubt in the minds of voters about Know Nothings' fealty toward slavery should be vehemently rejected. ${ }^{145}$

\footnotetext{
${ }^{141}$ American Union [Morgantown], June 30, 1855, quoted in Scott Alexander MacKenzie, "The Fifth Border State: Slavery and the Formation of West Virginia, 1850-1868," (Ph.D. diss., Auburn University, 2014), 79.

${ }^{142}$ Virginia Free Press [Charles Town], April 19, 1855, 2.

${ }^{143}$ Parkersburg Gazette and Courier, March 24, 1855, 2.

144 Wheeling Intelligencer, May 23, 1855, 2.

145 Wheeling Intelligencer, May 24, 1855, 2.
} 
Northwestern Know Nothings' rhetoric and pledges on the issue of slavery, though, often conflicted with their national platform. During their national convention, northern delegates, frustrated with the proslavery leanings of the party, rejected the southern plank of their organization's platform. Northern Know Nothings had passed anti-slavery resolutions in their home states and hoped to include these resolutions in the party's national platform. But southern Know Nothings' insistence on protecting slavery divided members. This fissure fueled Democratic claims that southern Know Nothings could not be trusted on the question of slavery, as they would capitulate to their northern colleagues and seek slavery's abolition. ${ }^{146}$

Northwest Democrats hounded Know Nothings on their supposed threatening stance on the issue of slavery, what one leading Democrat considered the "most important" issue of the election. ${ }^{147}$ For Democrats, the connection between Know Nothings and abolitionists was clear and compelling. "[P]rominent abolitionists" in Ohio candidly admitted that "Know Nothingism is intended to abolitionize the South" and spread their "infamous doctrines" throughout Virginia. ${ }^{148}$ Democrats charged that James Beale, Know Nothings' candidate for lieutenant governor, declared in a speech in Parkersburg that the "existence...of the institution of Slavery" produced the evils that afflicted the state. This denunciation of slavery sounded less "like the speech of a Virginian" and more "like the impious pratings of some suddenly transplanted Northern Abolitionist." 149 Know Nothings, in collusion with northern abolitionists, sought to repeal the Fugitive Slave Act and the Kansas-Nebraska Act while halting the interstate slave trade and abolishing slavery in the District of Columbia. "Were Virginians ready for this?"

\footnotetext{
${ }^{146}$ Cooper, Politics of Slavery, 363-369; Wilentz, Rise of American Democracy, 693-695; and Frank Towers, The Urban South and the Coming of the Civil War (Charlottesville: University of Virginia Press, 2004), 97.

${ }^{147}$ Spirit of Jefferson [Charles Town], March 20, 1855, 1.

${ }_{148}$ Cooper's Clarksburg Register, May 16, 1855, 2.

149 Weston Herald, April 4, 1855, 2.
} 
Democrat E.W. McComas of Kanawha County averred that such actions "boded no good to Southern rights."150 "Know Nothingism," the "foe of the South and the ally of Northern fanaticism," deserved a sound rebuke in the upcoming gubernatorial election to demonstrate that northwesterners detested their abhorrent doctrines. ${ }^{151}$

Wise defeated Flournoy in the 1855 gubernatorial election by approximately ten thousand votes, a similar majority Johnson enjoyed four years earlier. Traditional Democratic northwestern counties toed the party line, as Monongalia, Harrison, Marion, and Preston provided majorities to Wise. Typical Whiggish counties such as Wood and Ohio racked up large margins for Flournoy. ${ }^{152}$ Democrats rejoiced at Virginians' rejection of northern dogma. In electing Wise, voters illustrated that "they are Virginians; they are not Yankees." Virginians refused to embrace politics "from such a sink of painful infidelity, shallow learning, lechery, corruption, and hypocrisy" that had infected the abolitionist states of Massachusetts and New York. ${ }^{153}$ A Wheeling newspaper celebrated the results, congratulating voters for defeating that "new fangled humbug which had its origin in the brain of some Yankee."154 As during the previous gubernatorial election, the "politics of slavery" figured prominently, as partisans courted voters by stressing their party's fealty toward the peculiar institution. But voters, acclimated to this strategy, generally maintained party affiliation because they believed that their party offered the strongest defense of African American bondage. Perhaps most importantly, the gubernatorial election and the rise of the Know Nothing Party reflected the dynamic nature of Virginia's electoral system. Two viable political parties with distinct ideologies and platforms

\footnotetext{
${ }^{150}$ Weston Herald, April 11, 1855, 2.

151 Cooper's Clarksburg Register, January 10, 1855, 2.

152 The final vote total was 83,424 votes for Wise and 73,244 votes for Flournoy. Democratic candidates for lieutenant governor and attorney general both claimed victories by similar margins. Cooper's Clarksburg Register, August 22, 1855, 2.

153 Morgantown Telegraph, May 31, 1855, 2.

${ }^{154}$ Daily Argus (Wheeling), May 26, 1855, 2.
} 
continued to court voters in the Commonwealth, and neither party appeared in danger of fading. While national politics appeared to be ossifying in the 1850s, Virginia politics remained flexible. ${ }^{155}$

Know Nothings remained an electoral force throughout 1855 and into 1856. Know Nothing politician John S. Carlile of Harrison County won election in the Eleventh Congressional District, while the party maintained an organ in Morgantown and looked to remain a viable political alternative to Democrats. ${ }^{156}$ The party held regular meetings and Fourth of July parades in the region, maintaining its public presence among residents while remaining a thorn in the side of "Dimmykrats." 157 Know Nothings burnished their proslavery credentials, too, mocking "Black Republicans" while warning fellow Virginians about abolitionism and free soilism, two ingredients found in the "boiling cauldron of Northern fanaticism." ${ }^{158}$ Know Nothings stated unequivocally that they "are...good and loyal Virginians" who championed slaveholders' rights and defended slavery against all threats. ${ }^{159}$ Despite their recent gubernatorial defeat, Know Nothingism continued to find fertile ground in northwestern Virginia.

\footnotetext{
${ }^{155}$ William W. Freehling and Michael Holt make this argument in Freehling, Road to Disunion: Secessionists Triumph and Holt, Political Crisis of the 1850s.

${ }^{156}$ Link, Roots of Secession, 134 and Hall, Rending of Virginia, 577.

${ }^{157}$ American Union, July 7, 1855, 2 and August 18, 1855, 2. [emphasis in original]

${ }^{158}$ American Union, September 22, 1855, 2 and August 4, 1855, 2. [emphasis in original]

${ }^{159}$ American Union, February 9, 1856, 2.
} 
William Pope Cooper, a passionate Democrat and editor of the Cooper's Clarksburg Register, continued to hound Know Nothings on the issue of slavery. Know Nothings, like Whigs, exhibited a weakness on slavery that threatened the institution and white men's political independence. Southern Know Nothings appeared "willing to relinquish their constitutional rights" to appease "their abolitionist brethren of the North," proving once again that the party's members were not "sound upon the slavery question." 160 African American bondage generated and protected white men's "natural and Constitutional rights," Cooper asserted, and required vigilance upon the part of all Virginians to ensure slavery's health and vitality. Opponents of this fundamental southern axiom had to be defeated. ${ }^{161}$

On April 4, 1856, Cooper published an engraving that he believed revealed Know Nothings' true motives and actions. Under the caption "SAM KNOW-NOTHING," a young, male

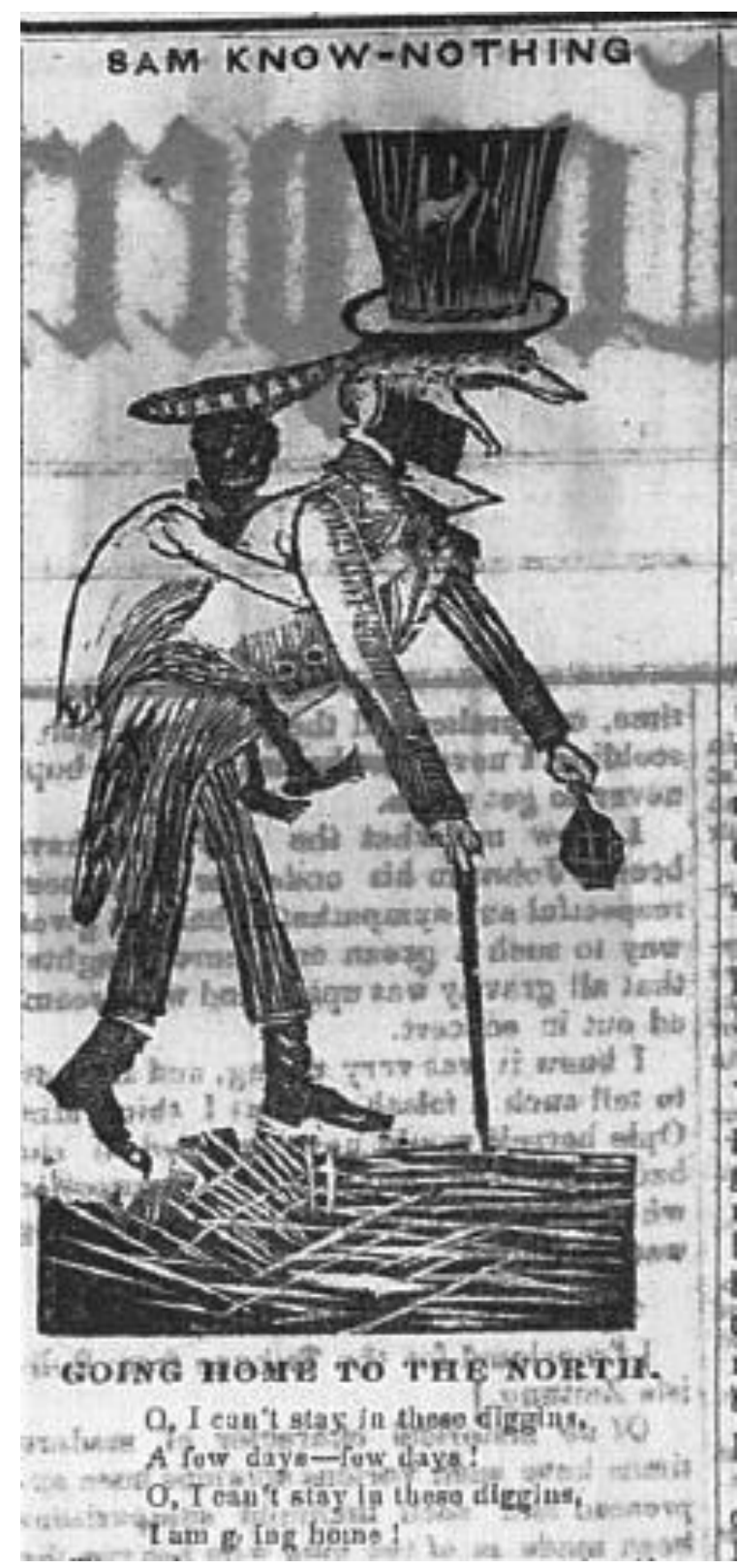
African American slave rides on the back of a well-dressed white man. The man dons a top hat, a jacket with long coattails, a high dress collar, a cane, and holds a money purse. A raccoon takes the place of the individual's head. In bold capital letters under the engraving, Cooper wrote, "GOING HOME TO THE NORTH." In a brief editorial below the picture, Cooper remarked that "Sam Know-Nothing" now found himself "making tracks for Yankee land"

\footnotetext{
${ }^{160}$ Cooper's Clarksburg Register, January 9, 1856, 3.

${ }^{161}$ Cooper's Clarksburg Register, October 3, 1856, 2.
} 
following his "fruitless efforts to proselyte" Virginians with his "abominable political heresies."

The connection between Know Nothings and northern abolitionists could not be more manifest.

"Sam," a "Yankee" exponent, espoused alarming messages that threatened the state's established racial and political hierarchies. "Sam" had "stolen a nigger and...resolved to devote himself more exclusively to that business hereafter." The issue of slave kidnapping represented a raw nerve in the body politic for many Virginians, notably those in the Northwest, who accused abolitionists of absconding with slaves. Know Nothings, Cooper averred, were complicit in such activities and disregarded proslavery legislation. Cooper, like other Democrats, believed that Know Nothings represented apostates to Virginia's slaveholding interests and had to be branded as hostile outsiders.

The political cartoon's iconography confirms Cooper's suspicion that Know Nothings represented Whigs incognito. This disguise, though, could not hide the same fundamental truth: Whigs and Know Nothings posed an acute threat to slavery. The raccoon serving as the figure's head reminded readers that while Know Nothings proclaimed to be a new party, the party represented the reincarnation of the Whig Party. During the 1844 presidential campaigns, Whigs used the raccoon and coonskin hat as a means of capitalizing on the rural identity that propelled them to victory during the previous presidential election. Democrats used the raccoon and coonskin hat to accuse Whigs of being political manipulators and traitors to the "common man," hiding under a hat rather than revealing their true identity. ${ }^{162}$ While Know Nothings paraded as a new political party, Cooper assured his audience that they were "the same old coon." 163

\footnotetext{
${ }^{162}$ David R. Roediger, Wages of Whiteness: Race and the Making of the American Working Class (New York and London: Verso, 1991), 98. During the 1840 presidential campaign, Whigs used the "log cabin and hard cider" iconography to identify the party with rural voters. The campaigning worked, as William Henry Harrison won the presidency over incumbent Martin Van Buren.

${ }^{163}$ Cooper's Clarksburg Register, April 4, 1856, 2. The political iconography associated with the raccoon may have gone deeper than partisan conflict. Gradually after 1848, "coon" emerged as a racial slur because of its connection with blackface minstrel shows, notably "Zip Coon." "Zip Coon," written by Thomas Birch in 1834, became
} 
The figure's fashion also provided important political and social commentary. The top hat, suit, cane, high collar, and coin purse represented the trappings of a northern aristocrat, a man of wealth that contrasted sharply with a northwestern yeoman farmer. Yeomen embodied the "homespun ideology" made fashionable during the American Revolution while Know Nothings, by contrast, were greedy northern capitalists who had strayed from the ideals of the Revolution. ${ }^{164}$ These references represented more than simple partisan conflict. Cooper illustrated that northwest Virginians would remain vigilant against threats to Virginia's republican institutions, notably slavery. Northwesterners would continue to identify and condemn politicians and parties that threatened the values and interests of "the people," promising to uphold and preserve southern democracy.

Cooper's political cartoon illustrates that northwestern Virginians by the 1850 s had deepened their commitment to slavery and to the state. Some residents, though, objected to this deepening commitment. As the Wellsburg Weekly Herald declared, "there are other interests in Virginia...besides those pertaining to slavery."165 "[S]lave influences" had "moulded, cramped

increasingly popular during the antebellum period through blackface minstrel shows. The lyrics, written to mock African American dialect and language, also touched on political events such as Andrew Jackson's presidency and the "Bank War," possible miscegenation, and even the possibility of an African American president. Blackface minstrelsy, popular among the northern working class, allowed audience members to express their racial anxieties and collective fears of a menacing and debased "other." White audience members laughed at the buffoonery on stage, mocking the irregular speech patterns and whimsical songs performed by white actors behind the burnt cork mask. In doing so, the audience constructed a political distance between themselves and African Americans. White men leaving the show believed that African Americans, obviously unfit for political or social equality, belonged in slavery and abolitionists who attempted to argue otherwise were foolish. The overt proslavery dialogue and imagery reinforced this latter point. Through this production of popular culture, white men emerged more assured of slavery's benefits for the slave and for the white republic. Eric Lott, "Blackface and Blackness: The Minstrel Show in American Culture," in Inside the Minstrel Mask: Readings in Nineteenth-Century Blackface Minstrelsy, eds. Annemarie Bean, James V. Hatch, and Brooks McNamara (London: Wesleyan University Press, 1996), 3-32; Alexander Saxton, "Blackface Minstrelsy," in Inside the Minstrel Mask; and University of Virginia: Uncle Tom's Cabin \& American Popular Culture [http://utc.iath.virginia.edu/minstrel/zipcoonfr.html] [accessed 7 March 2013] For references to minstrel shows in the Northwest, see Daily Evening Argus and Wheeling Commercial Advertiser, May 27, 1852, 2, 3.

${ }_{164}$ Michael Zakim, Ready-Made Democracy: A History of Men's Dress in the American Republic, 1760-1860 (Chicago: University of Chicago Press, 2003).

${ }^{165}$ Wellsburg Weekly Herald, March 21, 1856, 2. 
and controlled" the "entire legislation of the state" to the detriment of nonslaveholders. Lest residents labeled the newspaper an abolitionist organ, the Herald would remain aware of "all the existing interests and grievances of slaveholders" and repudiated the notion that "slavery [was] wrong in itself." Still, the Herald supported some form of gradual emancipation as it would serve and protect the "best interests of the white population of the State."166 Dissatisfaction over the state legislature's continued reluctance to appropriate funds for internal improvements and unfair taxation policies roiled some northwesterners who bemoaned eastern legislators' continued intransigence and the favoritism doled on their section of the state. ${ }^{167}$

These dissonant voices, though, remained on the political periphery. Grievances expressed by residents often included continued pledges of fidelity to the state and fealty toward slavery. Northwestern Virginians, "living on...[the] Western border," still felt "as much pride in and veneration" for the state and its institutions all other Virginians. ${ }^{168}$ As Granville Davission Hall later admitted, northwesterners "were Virginian in their traditions and did not give up their pride in the historic fame of the Commonwealth." ${ }^{169}$ Residents often confessed that they lived in one of the most democratic states in the country, and sought not to overturn established hierarchies but merely secure and protect the rights of western white men.

Many historians contend that during the 1850s, northwesterners drifted further away from the state and slavery, growing frustrated with the monomania that characterized Virginia's political culture in regard to African American bondage. But from the Constitutional Convention of 1850-1851 through the middle of the 1850s, northwesterners deepened and intensified their

\footnotetext{
166 Wellsburg Weekly Herald, April 11, 1856, 2.

${ }^{167}$ For example, see Wellsburg Weekly Herald, April 2, 1852, 2; Wellsburg Weekly Herald, January 27, 1854, 2; Weston Herald, January 2, 1854, 2; Weston Herald, February 6, 1854, 2;

168 Weston Herald, February 6, 1854, 2.

${ }^{169}$ Hall, Rending of Virginia, 71.
} 
attachment to Virginia and the peculiar institution. Rather than pursuing division, residents sought closer union. Instead of denouncing slavery, residents defended the institution. These sentiments would continue to pervade northwesterners' actions and thoughts through the secession crisis in 1860-1861.

As Lacy Ford has illustrated, as the process of democratizing state constitutions unfolded in the 1830s, politics emerged as the sole purview of white men as democratic reform flattened other distinctions. And as whiteness became the single characteristic demarcating freedom from bondage, white men fought to protect the institution that validated that racial divide and ensured their political representation. The racial and political implications were profound. The “imperatives and prerogatives of whiteness" became "clear and compelling" for white southerners, as this racial divide "gave a harder, uglier, and more permanent edge to the idea of racial differences." 170 Those who sought to challenge or overturn this fundamental axiom elicited the censure of white southerners.

This same phenomenon unfolded in Virginia after 1851. The 1851 Constitution provided political representation to all white men regardless of property, status, or socioeconomic status. With politics now open to all white men and race as the only division between liberty and slavery, white northwesterners passionately defended this axiom with arguably greater vigor than in previous years. Part of this increased intensity reflected the growth of groups hostile to slavery. Abolitionists, free soilers, and anti-slavery proponents all appeared determined to upset this ruling southern axiom and deny the benefits of whiteness that northwesterners had long sought. The differences between those extremists mattered little, as their ultimate objective appeared identical. The "politics of slavery," manifested through the state's two first popularly-

\footnotetext{
${ }^{170}$ Ford, Deliver Us from Evil, 532-533.
} 
elected gubernatorial contests, took on a greater urgency than in previous elections because the stakes were higher and more important. Each sign of political weakness could provide an opening for northern extremists to exploit. Though Democrats considered themselves the standard-bearer for protecting slavery, Whigs and Know Nothings engaged in similar tactics, professing their hatred for northern "isms" and "ists" while pledging their support for slaveholders and slavery. Political organizations attempting to break ground in the Northwest faced an immense challenge.

Northwesterners' increased intensity defending slavery and their fidelity to the state further reflected what Leigh, Dew, and Upshur had envisaged years earlier. By placing slavery at the core of Virginia's republican institutions, delegates at the constitutional convention tethered the health and longevity of slavery to that of the state government. Virginia's political and constitutional structures, interlaced with safeguards for slavery, shielded the peculiar institution from enemies within and without. The few critics who claimed that the state constitution furthered and protected the interests of slaveholders were correct; but the state constitution furthered and protected the interests of all white men, slaveholders and nonslaveholders alike, by promoting and protecting independence and liberty for all white men. This powerful dynamic subsumed class and political divisions, promoted sectional harmony, and created a united front among Virginians. Northwestern Virginians remained wedded to slavery and the state, the wellsprings of their political representation. 
Chapter 5: Defeating the "mongrel platform": Partisan Politics, Slavery, and the Limited Appeal of the Republican Party, 1856-1861

In late January 1861, Hancock County residents convened to discuss the crisis unfolding across the nation. In December 1860, South Carolina had seceded from the Union, and other states across the Deep South soon joined the Palmetto State to form the Confederate States of America. Virginia, the largest slaveholding state, remained in the Union, but events within and without the Old Dominion challenged its fealty to the nation. Virginia Governor John Letcher convened a special session of the legislature in early January 1861, and delegates approved a special election for representatives for a state convention to meet on February 13. Virginians believed that this convention would help determine the Commonwealth's fate, specifically whether it would join other slaveholding states in the new Confederacy or remain in the United States.

For Hancock County residents, the reasons for remaining in the Union were clear and compelling. Virginians, slaveholders and nonslaveholders alike, "can always obtain...their just rights...by remaining with the Union." And the "rights" Virginians "now enjoy[ed]" were numerous: "the credit and protection of our present government," along with "a share of the common territories, to the arms, the arsenals, the dockyards, and the navy." The federal government's military prowess protected Virginians, most recently in October 1859 when federal soldiers captured John Brown and his armed rebels at Harpers Ferry. Further, the nation's international credit facilitated commercial transactions, an attractive characteristic that could assist the Northwest's expanding industrial footprint. ${ }^{1}$

But Hancock County residents understood that the state's overwhelming investment in slavery led many Virginians, especially those east of the Blue Ridge, to aver that a union under a

\footnotetext{
${ }^{1}$ Wellsburg Weekly Herald, February 1, 1861, 2.
} 
Republican administration would prove fatal to African American bondage. But these Northwest residents found such fears unfounded. Northwesterners "sincerely sympathize with our Eastern Virginia friends in their present alarm, but...assure[d] them that...their fears are groundless and arise from a misapprehension of the intentions of our Northern friends." Remaining "faithful to the Union" represented the safest path for eastern Virginians concerned about their chattel. Northerners "will assist them in the maintenance of their just rights and labor with them for their enforcement," northwesterners maintained. "[S]ome conciliatory plan for the preservation of our institutions" should be pursued "without doing violence to the conscientious opinions of either Northern or Southern men." If Virginians wanted to protect and ensure slavery's immediate future, Virginians needed to remain in the Union. ${ }^{2}$

The argument that slaveholders' rights and slavery were safer in the Union received widespread acceptance in the Northwest. At a Union meeting in Parkersburg in early January 1861 , residents asserted that secession would prove ruinous to slavery. Northwesterners admitted that their neighbors across the Ohio River "have been guilty of flagrant acts of injustice" and had violated the "constitutional rights of slaveholders." But secession would destroy slavery. Joining the Confederacy would produce a "connexion fatal to [Virginia's] credit, her prosperity, and to the happiness of her people" by abrogating the constitutional privileges slaveholders possessed in the Union. "[W]e are fully persuaded that all our grievances may be redressed under the Constitution," residents concluded. Slaveholders' grievances could be addressed if the state remained in the United States; the uncertainty surrounding secession's effect on slavery should give pause to slaveholders as they contemplated Virginia's future. ${ }^{3}$

\footnotetext{
${ }^{2}$ Wellsburg Weekly Herald, February 1, 1861, 2.

${ }^{3}$ Wheeling Daily Intelligencer, January 4, 1861, 1. Stanley Harrold offers a similar argument concerning Border South residents' interpretation of the secession crisis and the future of slavery. The struggle to retain fugitive slaves impressed upon such southerners that only federal protection could guarantee the safety and perpetuation of their
} 
Northwesterners' declarations asserting their fealty to the Union, even as a Republican president assumed office, were common throughout the region. But historians have unfairly overlooked these pronouncements, selecting instead resolutions and declarations demanding an adjustment of the state's ad valorem tax and readjusting apportionment in the state legislature. These grievances appear to illustrate a growing antislavery sentiment in the Northwest and foreshadow residents' demand for a new state free from slavery. Granville Davission Hall argued that nearly all northwesterners were "fighting to get away from" slavery as the secession crisis unfolded. ${ }^{4}$ Northwestern Virginians' "natural association to Ohio and Pennsylvania" encouraged residents' to adopt northern "sentiments" and political "institutions," according to another historian. In a national crisis concerning slavery, these historians claim, northwesterners would align themselves with other northerners and choose the Union and the extermination of slavery. ${ }^{5}$

Current historians have reinforced these earlier interpretations, maintaining that the late antebellum era witnessed an increase of Unionist and antislavery or antislaveholder sentiment among northwestern residents. The rise of the Republican Party in the Northwest further transformed the state's political calculus, as northwesterners allegedly exhibited their true fealty by supporting a party devoted to ending slavery. Each national and state political contest widened the breach between eastern and western Virginians, as the former protected slavery while the latter advanced "free labor." By February 1861, that breach was a chasm. And as the secession crisis unfolded around them in early 1861, northwestern Virginians preached

economic and social systems. Stanley Harrold, Border War: Fighting over Slavery before the Civil War (Chapel Hill: University of North Carolina Press, 2010), esp. 196-201.

${ }^{4}$ Hall, Rending of Virginia, 50.

${ }^{5}$ Lang, West Virginia, 9. 
adherence to the Union over protecting slavery, an institution that had long shackled their political and economic capabilities.

In advancing this interpretation, historians echo the Republican memory of Virginia's intrastate conflict. Northwesterners' political isolation and alienation from Virginia's slaveholding culture reflected residents' increasing antipathy toward slavery and an acute recognition of slavery's deleterious political, social, and economic effects. Further, residents expressed a marked determination to destroy the "Slave Power" that wielded inordinate power and lorded over white nonslaveholders. Charles Ambler argued that Republicans "fed upon the discontent" manifested in the lack of internal improvements, unequal taxation, and an inadequate public education system. By 1860, Republicans within Virginia constituted a "formidable party...resolved to stand by the Union." ${ }^{\prime 6}$ Henry T. Shanks notes that the geographic "dissimilarity" between regions west and east of the Alleghenies exacerbated political tensions throughout the antebellum era. By 1861, few internal improvements existed that could conquer these geographic divisions and promote solidarity among Virginians. With railroads extending into northern and western markets, northwesterners drew closer to free states as they exited Richmond's political gravity. ${ }^{7}$

The perspective of irreconcilable differences emanating from western and eastern Virginia has continued to receive scholarly approval. Richard Orr Curry, while he challenged the Northwest's alleged monolithic nature, still posits that eastern and western Virginia

\footnotetext{
${ }^{6}$ Ambler, Sectionalism in Virginia, 338. The dominant motif in Ambler's Sectionalism in Virginia reflects the Republican memory of the state's sectional conflict. Ambler, a student of Frederick Jackson Turner, argued that western Virginia represented the country's future: an area with immense natural resources that could be tapped with "free labor" and governed by democratic principles. Eastern Virginia represented the nation's slaveholding and oligarchical past and the base of the "Slave Power." Northwesterners, since the early republic and through the antebellum era, evinced a clear opposition to slavery and eastern slaveholders because of the continued denial of democratic reform, political equality, state-supported internal improvements, and a public education system.

${ }^{7}$ Shanks, Secession Movement in Virginia, 8-14.
} 
constituted two separate civilizations on the eve of secession. Different constitutional and political principles combined with the Northwest's hostile climate for slavery encouraged the region to develop along a different trajectory than the rest of the state. William W. Freehling argues that in "vast southern white belt areas," such as the Northwest, "nonslaveholders felt less brotherhood with slaveholders." Indeed, the "fault lines" between the two groups continued to widen throughout the late antebellum era, turning numerous nonslaveholders into "antiConfederates" by $1861 .{ }^{8}$ William Link contends that "northwestern exceptionalism," an ethos incongruous with proslavery values, reflected years of "eastern domination" in politics and slaveholders' monomania concerning their chattel's protection. Northwesterners embraced the Republican Party, interpreting in the organization their opportunity to defeat the "Slave Power" that had long wielded power over western whites. ${ }^{9}$

Other studies exploring sectional tensions in Virginia have approached the late antebellum era through different lenses but have arrived at similar conclusions. Kenneth Noe, echoing Henry Shanks' argument about the lack of economic development in western Virginia, contends that the economic and social impact of railroads represented the "leading factor" in determining loyalty during the secession crisis. Northwestern railroads, connected to northern and western markets, transported northern goods, values, and institutions into the region while alienating residents from the state's slaveholding culture. Railroads in southwest Virginia, connected to Richmond, increased that region's commitment to slavery and the state. ${ }^{10}$ Northwestern Unionists exhibited most of the characteristics that Daniel W. Crofts identifies

\footnotetext{
${ }^{8}$ Freehling, South vs. the South, 22-23.

${ }^{9}$ Link, Roots of Secession, 252-254.

${ }^{10}$ Noe, Southwest Virginia Railroads, 8. This sense of economic integration within the state's slaveholding culture affirms Inscoe's interpretation concerning western North Carolinians support for secession in 1861. Inscoe, Mountain Masters.
} 
among Border South residents, including a firm belief that the Union provided a bulwark for slavery against antislavery forces. ${ }^{11}$ Crofts argues that geographical proximity to northern free states, a lack of state-sponsored internal improvements west of the Alleghenies, and a small slave and slaveholder population produced a "keen sense of regional isolation and resentment" among northwesterners. ${ }^{12}$ Northwestern residents, expressing their dissatisfaction through "an antislavery tone and a threat to divide the state," would finally achieve liberation during the Civil War. ${ }^{13}$

This historiographical consensus posits a clean and comfortable interpretation concerning late antebellum sectional tensions in the Old Dominion. Eastern Virginians' denial of internal improvements and political equality, when combined with the Northwest's geographical isolation and residents' commercial ties to northern and western states, attenuated residents' fealty toward slavery and the state over the preceding decades. By the late 1850s, northwesterners sought refuge in the Republican Party, a political vehicle that could politicize their disenchantment and challenge the "Slave Power." The Republican Party's growth in the Northwest appeared inevitable, as the region's political, demographic, economic, and social characteristics all appeared to provide fertile ground for the "free soil" and "free labor" party. Republicans also provided important leadership during the statehood movement, guiding northwesterners from political bondage to freedom in 1863. Republicans controlled the state and its memory.

Notable flaws, however, weaken this interpretation. Historians rely on extant Republican sources to explain northwesterners' interpretation of political developments in the late

\footnotetext{
${ }^{11}$ Daniel W. Crofts, Reluctant Confederates: Upper South Unionists in the Secession Crisis (Chapel Hill: University of North Carolina Press, 1989), 122-124.

${ }^{12}$ Crofts, Reluctant Confederates, 160, 409 n. 56.

${ }^{13}$ Crofts, Reluctant Confederates, 162.
} 
antebellum era. The two prominent Republican newspapers, the Wheeling Daily Intelligencer and Wellsburg Weekly Herald, enjoyed limited appeal in the region, providing historians a useful but highly subjective and narrow perspective. Republicans increased in strength during the late 1850s but their membership remained generally confined to the northern panhandle. Historians' selective use of the two newspapers, however, mischaracterizes and exaggerates Republicans' strength and appeal in the region. Northwesterners' deep engagement in the "politics of slavery," the numerous proclamations of fealty toward slavery and the state expressed by residents, and their recognition that black bondage protected white liberty demonstrates residents' firm attachment to Virginia and to African American slavery. A few northwesterners attempted to challenge this dominant paradigm but made little progress, encountering hostility from residents who interpreted their ideology as subversive and dangerous to established and traditional hierarchies. Political affiliations remained relatively constant in the region as northwesterners maintained that their party protected slavery, patriarchy, and whiteness.

Historians have often treated Virginia as a microcosm of the national struggle concerning slavery. Decades of conflict in the Old Dominion over slavery and slaveholders' prerogatives and privileges mirrored national crises, as western nonslaveholders and yeoman farmers chafed at eastern slaveholding oligarchs who protected their chattel while corrupting republican government. This anachronistic historiographical argument overlooks decades of northwestern support for slavery and slaveholders' privileges, as only a fraction of the population opposed this political dynamic. An armed conflict over slavery in the Old Dominion was not inevitable, even by 1861 . Further, historians misinterpret northwesterners' fealty toward the Union. Nearly all residents expressed unwavering fealty toward the Union but also pledged to protect Virginia and 
slavery, two institutions that blossomed under the Stars and Stripes and guarded and guaranteed their political representation and liberty.

The late antebellum era in northwest Virginia witnessed residents' continued struggle to protect racial hierarchy, patriarchy, and slavery from dangerous "isms" and "ists." Most northwesterners viewed Republicans not as saviors but sinners, acolytes of a northern, sectional party that advocated principles incongruous with traditional and established hierarchies. Northwesterners' hostility toward Republicans manifested their visceral disgust for a party that allegedly promoted racial equality and the overthrow of slavery. This hostility also manifested residents' continued devotion to other Virginians, including their slaveholding neighbors east of the Blue Ridge. The intrastate sectional struggle that had long characterized Virginia politics faded as residents continued to thrive under the 1851 Constitution. Disputes concerning legislative reapportion or ad valorem taxation reflected disagreements over the most effective means to protect slavery; they were not proposals to place the peculiar institution on the path toward extinction. Even as secession loomed, northwesterners remained devoted to slavery and to protecting eastern slaveholders' rights. The political struggles of the late antebellum era neither attenuated northwesterners' fealty toward slavery and the state nor increased residents' political isolation; rather the late 1850s witnessed northwesterners' strengthening their commitment to slavery and Virginia. Northwesterners were vanguards in Virginia's proslavery defense.

By 1856, the threats to slavery and slaveholders in Virginia appeared increasingly tangible and serious. Democrats considered themselves the standard-bearers of Virginia's slaveholding interest, identifying and vilifying opponents who showed the slightest weakness on the issue of slavery. Much of Democrats' derision fell on Know Nothings, a party that continued 
to recover from its gubernatorial defeat the previous spring. Know Nothings remained a potent political force, sharpening their proslavery message while assailing Democrats who appeared to equivocate on slavery. Northwestern Democrats and Know Nothings continued to operate within the "politics of slavery" throughout the 1850s, a reflection of residents' concern for African American bondage. This political calculus, though, changed as a new threat to slavery appeared in the Northwest.

In early August 1856, the Wheeling Daily Intelligencer published the proceedings of a Republican Party meeting held in the city. The newspaper commented on the meeting's attendance, the national Republican platform, and Republicans' desire to organize an electoral ticket for the forthcoming presidential election. Though "small in numbers," Republicans, warned the editors, represented a "movement calculated only for bad results." A "little reflection" among Republicans would manifest the "unfortunate consequences likely to result from their action" the editors felt, and would ultimately dissuade them from maintaining the party's presence in the Northwest. ${ }^{14}$

The establishment of the Republican Party in the Northwest has received much scholarly attention, as historians maintain that the party's founding hastened secession and the Civil War. Granville Davisson Hall celebrated the Republican Party, lauding its increasing membership despite increasing threats of violence and abusive epithets from opponents. ${ }^{15}$ Northwesterners embrace of the Republican Party, William Link argues, reflected residents increasing political isolation and their determination to arrest the power of the slaveholding regime. ${ }^{16}$ Republicans proved successful in achieving that goal, Richard G. Lowe contends. Eastern Virginians, fearful

\footnotetext{
${ }^{14}$ Wheeling Daily Intelligencer, August 12, 1856, 3.

${ }^{15}$ Hall, Rending of Virginia, 50, 68, 282, 503.

${ }^{16}$ Link, "“This Bastard New Virginia,"” 40-44.
} 
of a growing Republican electorate, advocated secession to stymie the party's expansion. Republicans helped guide the Northwest through secession and statehood, liberating white northwesterners from the political bondage enacted by eastern slaveholders. ${ }^{17}$ The founding of the Virginia Republican Party, according to historians, placed the Old Dominion on the inevitable path toward dismemberment.

For contemporaries and historians, a Virginia Republican Party centered in the Northwest appeared possible, if not plausible. Several factors appeared encouraging. The growth of southern cities, including Baltimore, St. Louis, and New Orleans, inaugurated a form of urban politics often incongruous with traditional "planter-influenced politics." Slaveholders worried that this increasingly heterogeneous urban population possessed values opposed to slaveholding interests, notably an affinity for "free labor" politics and an apathy or hostility toward slavery. Republicans, meanwhile, envisioned these urban dwellers establishing "bridgeheads for a Republican Party invasion of the South." Through patronage and political favors, Republicans could nurture these southern pockets of Republicanism and challenge slaveholder hegemony. ${ }^{18}$

The growth of southern cities in the 1840s and 1850s reflected an important demographic trend. Immigrants, notably Germans fleeing the failed 1848 Revolution, represented one of the largest constituencies in these southern cities and Wheeling was no different. Though Germans had immigrated to Wheeling during the preceding decades, their numbers increased following 1848 as thousands flooded the city in search of employment. By 1860, immigrants or their sons constituted approximately one-half of the city's voting-age male population, with most of these families residing in Wheeling's southern wards and specializing in trades and less-skilled

\footnotetext{
${ }^{17}$ Richard G. Lowe, “The Republican Party in Antebellum Virginia, 1856-1860," Virginia Magazine of History and Biography, 81, no. 3 (July 1973): 259-279.

18 Towers, Urban South, 7, 10, 14.
} 
occupations. Many Republicans believed that these plebeian laborers would embrace the party's "free labor" ideology, a tenet that emphasized social and economic mobility and the dignity of labor. ${ }^{19}$ This assumption carried some legitimacy. While the majority of pre-1848 German immigrants supported the Democratic Party, those arriving after the Revolution gravitated toward the Republican Party. The continued arrival of these Revolutionary Germans meant an increasing Republican electorate, too. ${ }^{20}$

The influx of German immigrants to Wheeling reflected the city's dynamic economic growth. Ironworks flourished in the 1850s, with rolling mills and foundries dotting the city's landscape. Glassworks, tanneries, and tobacco and cotton manufacturers continued to thrive, too. ${ }^{21}$ This growth appeared to distance Wheeling's residents from Virginia's planter-centered political economy. Manufacturers in Richmond and Petersburg often relied on agricultural goods produced by slave-labor, including tobacco, cotton, and hemp, generating ties between slaveholders and business leaders. ${ }^{22}$ But manufacturing in Wheeling, centered on the glass and iron industries, relied on few, if any, agricultural goods produced with slave labor. ${ }^{23}$ As one contemporary later reflected, Wheeling's "interests were industrial rather than agricultural," leading few to cultivate relationships with slaveholders and fewer still to own slaves. ${ }^{24}$

\footnotetext{
${ }^{19}$ Eric Foner, Free Soil, Free Labor, Free Men: The Ideology of the Republican Party before the Civil War (New York: Oxford University Press, 1970), esp. 11-39.

${ }^{20}$ Fones-Wolf, "Caught Between Revolutions," 21, 24, 25, 29 and Bruce Levine, The Spirit of 1848: German Immigrants, Labor Conflict, and the Coming of the Civil War (Urbana: University of Illinois Press, 1992), $250-253$. Levine also notes that post-1848 Germans welcomed Republican's opposition to slavery's expansion into western territories, as many Germans worried about competing with African American slaves for labor and wages. ${ }^{21}$ Anne Kelly Knowles, "Wheeling Iron and the Welsh: A Geographical Reading of Life in the Iron Mills," in Transnational West Virginia, 217.221.

${ }^{22}$ L. Diane Barnes, "Industry and Its Laborers, Free and Slave in Late-Antebellum Virginia," in The Old South's Modern Worlds, ed. L. Diane Barnes, Brian Schoen, and Frank Towers (New York: Oxford University Press, 2011), 189-206.

${ }^{23}$ Fones-Wolf, "“Traitors in Wheeling," 77-78.

${ }^{24}$ Henry Dickerson Scott, Iron \& Steel in Wheeling (Toledo, OH: Caslon Co., 1929), 32.
} 
These demographic and economic trends suggested that northwesterners might embrace the Republican Party. Virginia's intrastate sectional tensions also offered Republicans an opportunity to test the party's "Slave Power" thesis. Republicans argued that a conspiratorial "Slave Power" manipulated the U.S. Constitution and corrupted democratic politics to protect slavery and slaveholders' interests. ${ }^{25}$ The work of the "Slave Power" colored Virginia's history, Republicans maintained. For decades, eastern slaveholders denied western nonslaveholders political representation and equality, and used the structures and functions of the state government to shield the institution and further slaveholders' privileges. Opposing the "Slave Power" could result in "blood or banishment," one Republican warned. ${ }^{26}$

Republicans hoped to politicize Virginia's sectional discord and channel it into party politics. Virginia Republicans could effectively check slaveholders' power and address the few political and constitutional inequalities that remained on the books. A Virginia Republican Party could also, Republican editor John G. Jacob believe, provide "organization and concert" for men not "habitually disposed to dabble in politics." Jacob and other Republicans worried that many farmers, laborers, and yeomen avoided politics because Democrats and Know Nothings championed the slave interest over all others. Without Republicans' assistance, these northwesterners "are practically disenfranchised," making their party invaluable. ${ }^{27}$ Republican success in Virginia could translate into similar movements in other southern slaveholding states, including Missouri, Maryland, and Delaware, where Republicans would continue to battle the "Slave Power."

\footnotetext{
${ }^{25}$ Foner, Free Soil, Free Labor, Free Men, esp.73-102.

${ }^{26}$ John C. Underwood to Archibald W. Campbell, 21 January 1859, Archibald W. Campbell Papers, A\&M 14, Box 1, Folder 1: 1855-March 1859, WVRHC.

${ }^{27}$ Wellsburg Weekly Herald, April 20, 1860, 2.
} 
Despite these favorable characteristics, Republicans discovered that northwestern residents were not as receptive as initially conceived. Few residents recanted their previous proclamations concerning slavery and slaveholders' rights, especially since many had deepened their engagement in the "politics of slavery" following the ratification of the 1851 Constitution. The "high minded loyal citizens of the Commonwealth" rejected Republicans who sought to "bring us to a level with negroes and Yankee pedlers." Speaking against slavery was tantamount to attacking the political prerogatives of all white men, an action that could elicit a violent reaction. "Wheeling cannot consent to become the asylum for politicians of the black creed," one northwestern newspaper editor averred. "Trifle not with public sentiment. Defy not the will of the people," he warned Republicans. ${ }^{28}$ After learning that another Republican meeting would be held in Wheeling, the "Union and Constitution-loving men of the South...advise[d] the members of that party to change both time and place." The editors of the Wheeling Daily Intelligencer warned Republicans that those opposed to this meeting would "protect" the city's reputation. $^{29}$

Such veiled threats of violence against Republicans carried legitimacy. A melee ensued in Wheeling following a Republican meeting as the speaker, Dr. G.P. Smith, was "met with rough handling" following his speech. Smith defended himself with a knife against assailants, leaving two men with lacerations and the doctor in jail. The editors of the Wheeling Daily Intelligencer were "not surprised that our citizens are incensed at this Republican effort." Outbreaks of violence directed toward Republicans could be excused because "this little band" possessed "aims [that] are at war with the institutions of Virginia." Republicans' opposition to slavery's expansion appeared tantamount to abolitionism, a dangerous doctrine that threatened

\footnotetext{
${ }^{28}$ Wheeling Argus, September 19, 1856, 1.

${ }^{29}$ Wheeling Daily Intelligencer, September 15, 1856, 2.
} 
established political and social hierarchies. Northerners attempting to settle in Virginia needed to understand what it meant "to be true to Virginia." Being faithful to the Old Dominion meant supporting and defending slavery. ${ }^{30}$

The attacks levied against Republicans signaled northwesterners continued struggle to protect whiteness. “Abolitionists, Atheists, Socialists...Disunionists, negro worshipers in theory...Beechers and Stowes" all supported the same "mongrel platform" that Republicans and Know Nothings championed. In short, Republicans "advocate every change from the established order of things, no matter how ruinous to society." 31 All white men stood to lose if Republicans abolished slavery. Abolition would "at once place the poor white man and free negro upon the same level," dragging the "white laborer down to the same wretched pittance and...degraded condition and level" that African Americans occupied, a Democratic newspaper insisted. ${ }^{32}$ Northwesterners would “spurn... all new-fangled, false philanthropic, degenerating, disorganizing attempts of brainless innovators upon her ancient and well tried institutions." ${ }^{33}$ Republicans threatened the Union, southern society, and the household, all domains structured on patriarchy. Further, the political rights white northwesterners acquired only a few years earlier would be devalued or eliminated with Republican political dominance. Republicans' attacks on slavery targeted more than the institution; they targeted all parts of southern society.

As the 1856 presidential election approached, residents increased their engagement in the "politics of slavery." Know Nothings, embittered by their recent gubernatorial defeat, attempted to distance themselves from Republicans and abolitionism. Accusations concerning Know Nothings' abolitionist sentiment "won't lie, though every one who makes it does," the

\footnotetext{
${ }^{30}$ Wheeling Daily Intelligencer, August 18, 1856, 3.

${ }^{31}$ Wheeling Daily Intelligencer, May 13, 1856, 2.

${ }^{32}$ Kanawha Valley Star, November 4, 1856, 2.

${ }^{33}$ Wheeling Argus, September 19, 1856, 1.
} 
Morgantown American Union declared. ${ }^{34}$ Any association "between Black Republicanism and Americanism" represented an egregious "mistake," as Know Nothings held nothing in common with the "wooly heads" of the Republican Party. ${ }^{35}$ Those "Ultraists of the North... originated a crusade upon slavery" and had to be defeated, Know Nothings declared. ${ }^{36}$ Though Republicans professed not to meddle with slavery where it existed, the "rankest and most ultra ABOLITION sentiments and appeals" had infected the party and soon Republicans would demand slavery's abolition. ${ }^{37}$ The sectional nature of the Republican Party signaled more trouble on the issue of slavery. "Black Republicanism cannot reconcile our difficulties, because it is...sectional" and "both its candidates [are] from the North." ${ }^{38}$ How could a sectional, northern party be trusted to protect slavery? Further, the proslavery, anti-foreign Know Nothing Party would disenfranchise the "foreign vote" in the North, a "pestiferous source of Abolition power."39

Democrats could not escape Know Nothings' criticism either. Know Nothings questioned two Democratic state legislators who allegedly voted against a bill that would have increased slave patrols on maritime commerce to prevent runaway slaves from absconding. “They ain't Black Republicans, too, are they?” Charges by Democrats that Know Nothings sought to repeal proslavery legislation amounted to "deliberate falsehood[s]" designed to discredit Know Nothings' proslavery position. True protection for slavery, Virginia, and the nation rested in the Know Nothing ticket. By electing Millard Fillmore, Virginians would ensure the perpetuity of the Union, repudiate "Black Republicanism," and secure allies who would ensure slavery's protection.

\footnotetext{
${ }^{34}$ American Union, December 3, 1858, 2. [emphasis in original]

${ }^{35}$ American Union, February 23, 1856, 2.

${ }^{36}$ American Union, December 22, 1855, 2.

${ }^{37}$ American Union, September 27, 1856, 2.

${ }^{38}$ American Union, October 25, 1856, 2.

${ }^{39}$ American Union, May 3, 1856, 2.
} 
Democrats assailed both Know Nothings and Republicans on their supposed infidelity toward slavery, maintaining that African American bondage "was the issue of the canvass and on it alone the contest would be decided. ${ }^{\prime 40}$ Know Nothings constituted a favorite target for Democrats who believed that the party's clandestine nature and northern membership demonstrated the American Party's weakness on slavery. The American Party represented the northern "stepping stone" that allowed the "black clan" to elect Republican representatives, senators, and governors. ${ }^{41}$ Under pressure from its northern wing, Know Nothings, Marion County lawyer Alpheus F. Haymond alleged, had "became sectional and abolitionized." Rumors of Know Nothings celebrating Republican John Fremont's victory in Pennsylvania validated Democrats' accusations of their opponents' "sympathies for the black flag of niggerism." ${ }^{43}$

While engaged in the "politics of slavery," partisans often engaged in questionable tactics to demonstrate their opponents' weakness on slavery. A Know Nothing elector from the Shenandoah Valley canvassing the Northwest supposedly confessed that Millard Fillmore "was prejudiced against slavery," a charge Democrats had long suspected. Further, Virginians were "foolish" to fight for slavery in the territories; as a political minority in Congress, southerners should "compromise with Northern fanaticism or be driven to the wall." Democrats found his conclusion repulsive. Virginians should "give up all their natural and Constitutional rights, and cry 'amen' to the fanaticism of the nigger stealers." ${ }^{\text {"4 }}$ While the newspaper's transcription of the

\footnotetext{
${ }^{40}$ Wheeling Daily Intelligencer, September 30, 1856, 2.

${ }^{41}$ Wheeling Argus, April 11, 1856, 2.

${ }^{42}$ Cooper's Clarksburg Register, October 17, 1856, 2.

${ }^{43}$ Cooper's Clarksburg Register, October 24, 1856, 2.

${ }^{44}$ Cooper's Clarksburg Register, October 3, 1856, 2.
} 
speech can be questioned, Democrats wanted the message to be clear: a Know Nothing victory imperiled slavery.

Republicans posed an equally dangerous threat to slavery, Democrats asserted. While northern Know Nothings dictated the party's platform, Republicans purely sectional and northern electorate forecasted danger for southern institutions. "Fremont has a ticket in every Northern States," one newspaper editor warned, "but no Southern State" had been canvassed by Republicans. ${ }^{45}$ John C. Frémont, the "Republican-Abolition candidate," according to a Democratic organ, sought to abolish slavery and champion "Free Love and Polygamy." Republicans' desire to destroy slavery and inaugurate these two lifestyles threatened white men's patriarchal power in both the public and private spheres. ${ }^{46}$ Democrats were incredulous that even a small number of Virginians supported Frémont knowing that his party threatened patriarchy. "[I]s it possible, that men in Virginia...prefer Fremont to Buchanan," a Democratic partisan questioned. The Old Dominion and its institutions deserved Virginians' "undying protection" from the "damnable doctrines" of northern abolitionists who sought to upset established hierarchies. ${ }^{47}$ Only the election of James Buchanan, a Pennsylvania Democrat who would equally abhorred these "doctrines," could prevent such calamities from unfolding across Virginia and the South.

The partisan attacks coupled with the innuendo and misinformation surrounding Republicans stunted the party's growth. Few northwesterners supported the party, leaving the handful of Virginia Republicans to lean on Ohio or Pennsylvania Republicans for political and

\footnotetext{
${ }^{45}$ Wheeling Daily Intelligencer, July 25, 1856, 2.

${ }^{46}$ Wheeling Daily Intelligencer, July 23, 1856, 2. For a Democratic attack on Know Nothings' alleged support for “woman's rights," see Cooper's Clarksburg Register, June 25, 1856, 2.

${ }^{47}$ Cooper's Clarksburg Register, October 24, 1856, 2.
} 
emotional support and speakers for meetings. ${ }^{48}$ Violence plagued Republicans, too. In Wellsburg, the staff of the Wellsburg Weekly Herald hoisted an American flag above their printing house in support of Republican John Frémont. Their neighbors interpreted the flag as the banner of "black Republicanism" and "swore that down it must come." A "poor, crazy lunatic" performed this "damning deed," and served as a warning for other northwestern Republicans who supported Frémont. ${ }^{49}$

Despite the criticism and physical threats levied against Republicans, members continued to convene in the region and recruit other northwesterners into their party. During Republican meetings, members expressed maintained the steady drumbeat of "free soil" and anti-“Slave Power." In Wheeling, Republicans condemned both Democrats and Know Nothings for christening "the extension of slavery the paramount object of government" while marginalizing all other interests. Republicans reaffirmed their position that Congress could not "interfere with any of the States in regard to the 'peculiar institution,"' but supported Congress' power to "prohibit the extension of slavery" into the territories. ${ }^{50}$ This "free soil" platform would protect white laborers' social and economic mobility in western territories. Equally important, "free soil" would halt the expanding "Slave Power."

Virginia Republicans believed that the "Slave Power" operating in the Old Dominion had retarded economic growth and undermined political equality. Hancock County Republicans reaffirmed their support for "free soil" for western territories because of slavery's deleterious effects in the Northwest. Slavery acted as an "incubus upon the energies of the white population, keeping a large part...in ignorance and poverty." ${ }^{51}$ Further, the Virginia "Slave Power" had long

\footnotetext{
${ }^{48}$ Wheeling Daily Intelligencer, September 19, 1856, 3.

${ }^{49}$ Wheeling Daily Intelligencer, October 11, 1856, 2. [emphasis in original]

${ }^{50}$ Wheeling Daily Intelligencer, October 1, 1856, 2.

${ }^{51}$ Wellsburg Weekly Herald, April 11, 1856, 2.
} 
protected its chattel by "violating the constitution," notably "by passing laws abridging the freedom of speech and of the press." The "Slave Power" decreed that "equality cannot be recognized but by an investment...in the purchase of Slaves" but acquiring slaves "would but strengthen the fetters which now trammel us in our state affairs." Every slave that entered Virginia strengthened the institution and the "Slave Power" while other interests suffered. Faced with this conundrum, northwestern Republicans longed for 1865 when, according to the 1851 Constitution, Virginians could reapportion the state legislature. Apportioning both houses on the "white basis" would "proclaim to the world that Virginia is redeemed" and liberate the "free white race in Virginia" from political bondage. ${ }^{52}$

The returns of the 1856 presidential election revealed to Republicans that the "Slave Power" continued to maintain its hold on politics. Most residents interpreted the election as a affirmation of the "politics of slavery" and the continued dynamism of the Northwest's two-party system. ${ }^{53}$ Residents recognized that the "slave question was the sole issue in the election," and declared by their votes that Democrat James Buchanan would protect slavery. ${ }^{54}$ Buchanan easily carried the Northwest and Virginia, with Know Nothing candidate Millard Fillmore finishing second and Republican John Frémont a distant third. As with previous presidential and gubernatorial elections, northwesterners' traditional political affiliation held sway. Buchanan performed well in the northern panhandle counties of Brooke, Hancock, and Ohio, along with

\footnotetext{
${ }^{52}$ Wellsburg Weekly Herald, September 12, 1856, 2. For other references of Republicans proclaiming 1865 to be the year of white northwesterners' liberation from slaveholders, see [Wheeling] Daily Intelligencer, June 10, 1859, 2; June 20, 1859, 2; and March 13, 1860, 2.

${ }^{53} \mathrm{My}$ interpretation concerning the significance of the 1856 presidential election on Virginia politics differs from that of William Link. Link argues that the presence of the Republican Party, though infinitesimal, suggested the existence and growth of opponents to Virginia's "southern rights agenda." Enough Republicans existed in the Northwest, he suggests, to "give pause to the slave regime." This argument, though, exaggerates Republicans' presence and reveals foreknowledge of the continued growth of the Republican Party. Further, the election returns strongly suggest the continued entrenchment of the two-party politics, a system that revolved around the protection of slavery. Link, Roots of Secession, 167-168.

${ }^{54}$ Wellsburg Weekly Herald, November 7, 1856, 2.
} 
Monongalia, Harrison, Marion, and Preston. Fillmore fared better than previous Whig/Know Nothing candidates in the state, carrying, among others, Kanawha and Marshall counties.

Frémont, receiving 291 votes or $0.2 \%$ of all ballots cast statewide, failed to carry a single county. He received his strongest support in the northern panhandle counties of Hancock, Ohio, and Brooke, along with a few scattered votes in Monongalia and Upshur. ${ }^{55}$ Republicans' lackluster turnout depressed members, as one solemnly remarked that the election passed "quietly and soberly" with "large democratic majorities" in numerous precincts. ${ }^{56}$ This Republican's dour observation reflected most Republicans' uncertainty of whether their party could thrive on southern soil. The lack of voter turnout further reflected residents' skepticism of Republicans' political ideology and the continued entrenchment of the two-party system.

Republicans, unable to tailor their message to the "politics of slavery," remained peripheral and alien to most northwesterners in 1856 .

Republicans' poor showing revealed the Northwest's political dynamics. The continued use of viva voce balloting probably frightened a handful of Republicans who wanted to vote for Frémont but reconsidered when faced with threats, intimidation, and ostracism from neighbors. Still, that number would not have been significant enough to swing any county. Rather, residents' continued engagement in the "politics of slavery" and their defense of "whiteness" contributed to Republicans' low turnout. For decades, residents had extolled their nominee's proslavery credentials while characterizing their opponent as weak on this seminal issue. This practice held firm in the election. The majority of northwesterners believed that Republicans'

\footnotetext{
55 These figures are derived from election returns reprinted in Cooper's Clarksburg Register, December 5, 1856,2 and Wheeling Daily Intelligencer, December 12, 1856, 3. Frémont received 108 votes in Ohio County; 100 in Hancock; 40 from Brooke; 2 in Monongalia; 20 from Marshall; and 10 in Upshur. Other Virginia counties that supported Frémont included Alexandria (1 vote); Shenandoah (5); and Scott (5).

56 Wellsburg Weekly Herald, November 7, 1856, 2.
} 
political ideology threatened slavery and whiteness, two cornerstones of Virginia's political culture.

Republicans' alleged support of abolitionism, amalgamation, polygamy, socialism, and atheism, ran counter to white northwesterners' beliefs and threatened to upset established political, racial, economic, and social hierarchies. Northwesterners were pleased by the Republicans' trouncing; they had defeated another dangerous northern "ism."

Northwestern Democrats rejoiced at

Buchanan's victory, interpreting it a reaffirmation of their party's "safe" stance on African American bondage. To celebrate their "GLORIOUS VICTORY," Democrats planned a "TORCH-LIGHT PROCESSION"

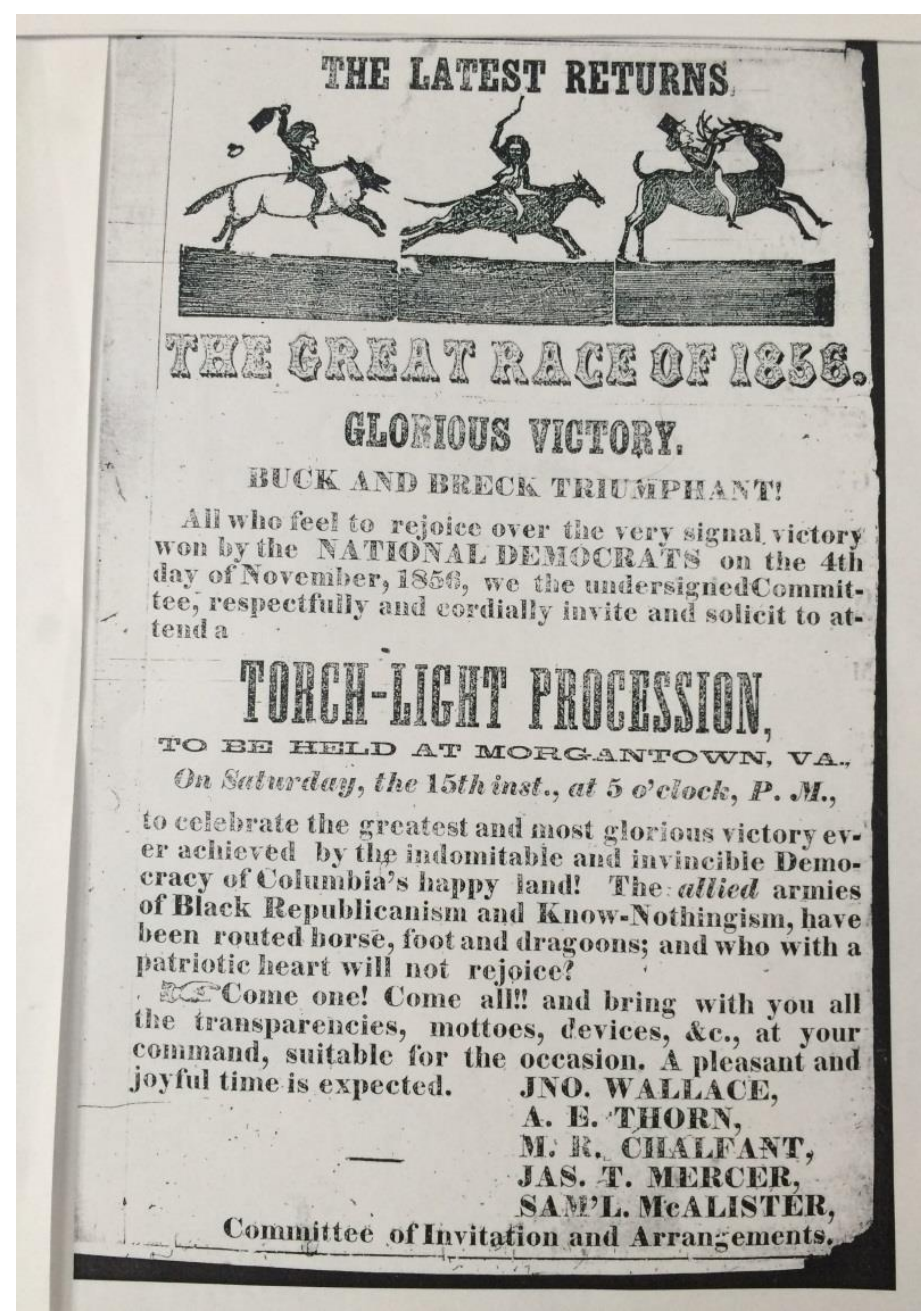
through the streets of Morgantown in Monongalia County. The advertisement for the procession included a wood engraving of the three presidential candidates astride three different animals. James Buchanan, or "Buck," represents the figure on the right riding a male, antlered deer, and winning “THE GREAT RACE OF 1856.” The two other figures represent Buchanan's defeated opponents. The middle figure, John Frémont, rides a black horse, a reference to the denigrating "black" epithet opponents associated with Republicans. Frémont also brandishes a whip, an instrument wielded by slaveholders to punish and compel slaves to work, and a tool that Republicans would use on white southerners if elected. Millard Fillmore, the Know Nothing nominee, represents the figure on the left. Fillmore sits atop a wolf in sheep's clothing, 
reflecting Democrats' accusations that Know Nothings proclamations extolling their position on slavery rang hollow. The dark lantern held by Fillmore signals his party's clandestine suspicious nature. As Democrats maintained, the "allied armies of Black Republicanism and KnowNothingism" could not be trusted on the issue of slavery; Virginians needed to rely on "indomitable and invincible" Democrats to protect African American bondage. ${ }^{57}$

Though northwestern Democrats claimed victory in 1856, nearly all northwesterners felt that the election reaffirmed their fealty toward slavery. "No portion of Virginia is more loyal to the institutions of the State," exclaimed a Charleston newspaper, "or more devoted to the rights of the South, than the Trans-Alleghany." Practically all residents were "proslavery" in sentiment. ${ }^{58}$ The same newspaper supported legislation that would exempt slaveholders from paying taxes on one slave, allowing all Virginians the opportunity to purchase a slave and "rapidly diffuse slaves in every portion of the State." This would further generate a "strong proslavery sentiment" throughout the region. ${ }^{59}$ At a Democratic meeting in Harrison County, residents denounced the "erroneous belief abroad that Virginia is not a unit on the question of slavery." The "West is now, and ever has been devoted" to slavery, and challenged anyone to contradict this assertion. ${ }^{60}$ Further, residents' paternalistic arguments reflected their deep investment in slavery, maintaining that slaveholders provided "all his slaves with good food and raiment whether they earn it or not." Moreover, "slave labor" was much more "lenient" than Republicans" "free labor." ${ }^{\text {"1 }}$ Travelers in the region noted the prevalence of southern attitudes, notably the hostility directed toward those who hailed from northern states. Upon visiting

\footnotetext{
${ }^{57}$ [Unknown newspaper][n.d.] Monongalia County Scrapbook, A\&M 1007, WVRHC.

${ }^{58}$ Kanawha Valley Star, August 31, 1858, 2.

${ }^{59}$ Kanawha Valley Star, September 15, 1857, 2.

${ }^{60}$ Cooper's Clarksburg Register, November 12, 1858, 2.

${ }^{61}$ Fairmont True Virginian, April 19, 1856, 2.
} 
Fairmont, one northerner "learned that northern men were not wanted in any part" of the Northwest. ${ }^{62}$

These pronouncements defending slavery and Virginia left many northwestern Republicans dumbfounded. For decades, Republicans exclaimed, eastern slaveholders had cowed and duped white northwesterners while retarding the state's economic growth and undermining political equality. Virginia's "nigger interest have ever been hostile to the interests of the wool growers," a Northwest Republican organ explained, "[and] has ever been dead against the iron interest of the country." Northwesterners' representatives had done little to resolve this situation. Instead of securing economic freedom and political equality, these politicians "have frequently gone into elaborate expositions to show that we...were all right on the peculiar question.” By supporting Virginia's slaveholding regime, northwesterners defended planters and elites who disregarded western interests. ${ }^{63}$ These "poor emasculated drivels of a Turkish harem" have been "bagged neck and heels for the use of the Sublime Porte at

\footnotetext{
${ }^{62}$ C.R. Pomeroy to Waitman T. Wiley, 24 July 1857, Charles H. Ambler Collection, A\&M 122, Box 10, Folder 5, item 228, WVRHC. Northwesterners' southern attitude carried over into their interpretation of Preston Brooks' caning of Charles Sumner. Residents defended Brooks' action, placing the blame on Sumner as "abolitionists recognized no gentle manly responsibility." Sumner possessed no privilege "to heap violent abuse upon another," and deserved the punishment Brooks doled out. "Every man who has the least spark of southern feeling" believed that Sumner's "insulating language" constituted "sufficient provocation." Even the Republican Wellsburg Weekly Herald characterized Sumner's denunciatory speech of Brooks' relative, Senator Andrew Butler, as "severe, indisputably and no doubt its severity was not softened by anything in the manner of the Speaker." Such attitudes reflected continued animus toward abolitionists, and the alignment of northwesterners' attitudes with that of other southerners. Star of the Kanawha Valley, June 4, 1856, 2; Star of the Kanawha Valley, June 11, 1856, 2; Cooper's Clarksburg Register, June 6, 1856, 2; Fairmont True Virginian, May 31, 1856, 2; and Wellsburg Weekly Herald, May 30, 1856, 2.

${ }^{63}$ Wheeling Daily Intelligencer, April 2, 1858, 2. The Intelligencer's hostile stance toward slavery can be explained by the newspaper changing hands in 1856 when Archibald W. Campbell, along with John F. McDermot, purchased the paper. Republicans' financial support of the paper following the 1856 Presidential election, along with Campbell's advocacy of freedom of the press, led to the publication of many antagonistic arguments directed against slavery, eastern Virginians, and those in western Virginia who supported the state's slaveholding interests. This change in proprietorship did not go unnoticed by other newspaper editors loyal to slavery. The editor of the Fairmont True Virginian denounced the work of Campbell who "has been pouring out some of the vials of his Black Republicanism upon us." Fairmont True Virginian, November 7, 1857, 2. William Cooper, the editor of the Cooper's Clarksburg Register, labeled Campbell a "nigger stealer" and that "Woolly Filthy in Wheeling." Cooper's Clarksburg Register, August 20, 1858, 2.
} 
Richmond," the Wheeling Daily Intelligencer lamented. ${ }^{64}$ Cowed into submission by the "Slave Power," northwestern representatives secured little for their constituents as "all legislation, great and small" supported eastern Virginia. ${ }^{65}$

No piece of legislation embodied northwesterners' submission to eastern slaveholders than the state's ad valorem tax, Republicans argued. While Virginia taxed all forms of private property ad valorem, slaves younger than twelve were exempt while the state capped the tax on those twelve and older at $\$ 300$. The increasing value of slaves in Virginia now made this policy especially onerous and objectionable to nonslaveholders, Republicans alleged ${ }^{66}$ Eastern Virginians implemented these tax exemptions "to encourage and foster slavery," shielding slaveholders from burdensome taxes while the "non-slaveholder and laboring white man" paid the full allotment of taxes. ${ }^{67}$ "Equality in taxation is what we want, be the taxes high or low," demanded Republicans, "and anything else is both degrading and oppressive." 68 But why had so few residents publicly condemned this policy or the "Slave Power" in Richmond? "Were it not that the fear of being called 'abolitionists' deters you, you would have repudiated this reign on iniquity long ago," Republicans claimed. But the "spell of enchantment" placed on northwesterners by eastern slaveholders convinced them that all white Virginians possessed similar interests. Republicans wanted to break that spell. ${ }^{69}$

Chief among Republicans' attempts to defeat the "Slave Power" was emphasizing the benefits of "free labor." Slavery bred "vice and slothfulness" wherever it expanded, endangering

\footnotetext{
${ }^{64}$ Wheeling Daily Intelligencer, January 15, 1858, 2.

65 Pruntytown Visitor, republished in Daily Intelligencer, April 23, $1860,1$.

66 Tarter, Grandees of Government, 149-150 and 413, n. 25. Tarter estimates that the selling of Virginia slaves to southern markets represented the Commonwealth's top commodity by the end of the 1850s.

${ }^{67}$ Wellsburg Weekly Herald, May 11, 1860, 2 and Wellsburg Weekly Herald, September 18, 1857, 2.

${ }^{68}$ Wellsburg Weekly Herald, February 24, 1860, 2.

${ }^{69}$ Wellsburg Weekly Herald, May 11, 1860, 2.
} 
the Northwest's "free laboring classes."70 But further economic decay, emigration, and poor work habits could be prevented if Virginia would "commit the industrial interests of the State to intelligent Anglo-Saxon labor."71 Western Virginia's abundant natural resources and burgeoning industries required "free labor" for the region to achieve its full economic potential. The salubrious effects of "free labor" were clear at the Belmont Nail Works, the second largest nail factory in Wheeling and location of one of two blast furnaces in the city. ${ }^{72}$ The "enlightened and intelligent appearance of the operatives, from the highest to the lowest in station" provided clear evidence that "free labor" benefited all white workers regardless of status. Further, the generous wages these employees earned provided clear evidence that "free labor" could thrive in northwestern Virginia. ${ }^{73}$

Embracing "free labor" would strengthen northwestern laborers and transform many of them to stalwart Republicans. But in order to defeat the "Slave Power," northwesterners needed to appreciate the power and operations of this conspiratorial cabal. For decades, eastern Virginians had deemed "the price of niggers the rule by which to determine any question of State policy."74 What were the results of this policy? "Free speech is suppressed and freedom of the press abridged by the populace, where" such words "infringe[d] upon the sacredness of slavery." "Mob law" reigned, as northwesterners intimidated and lashed out in violence against those opposed to slavery. ${ }^{75}$ "[C]otton, tobacco, and niggers" represented the state's prevailing interests. $^{76}$ But Republicans identified a silver lining. The Northwest's declining slave

\footnotetext{
${ }^{70}$ Wheeling Daily Intelligencer, February 5, 1858, 2.

${ }^{71}$ Wheeling Daily Intelligencer, April 13, 1857, 2.

72 Ohio County Public Library, "The Belmont Nail Works, Wheeling, WV," Ohio County Public Library [http://www.ohiocountylibrary.org/wheeling-history/the-belmont-nail-works-wheeling-wv/2707][accessed 3 June 2015].

${ }^{73}$ Wheeling Daily Intelligencer, August 5, 1857, 2.

${ }^{74}$ Wheeling Daily Intelligencer, September 15, 1857, 2.

75 Wellsburg Weekly Herald, January 27, 1860, 2.

${ }^{76}$ Wheeling Daily Intelligencer, July 1, 1857, 2. [emphasis in original]
} 
population forecasted the impending collapse of the "Slave Power." Boosterism literature for Parkersburg extolled the city's commercial advantages while noting that "slavery in North Western Virginia is an institution existing only in name." Indeed, "free white labor is the productive power of the region" and immigrants would not compete with African American slaves. ${ }^{77}$ The Northwest's declining slave population, an "inexorable" trend, would continue unabated regardless of "impotent protests and pseudo indignation resolutions" that claimed northwesterners' fealty toward slavery. A waning slave population would weaken residents' support for slavery and ultimately decrease the dominion of the "Slave Power." Freed from political bondage, northwestern residents "true interests" with the "border free states" would become realized. ${ }^{78}$

Republicans' optimistic outlook, though, clashed with reality. Dissatisfaction with the tax exemptions enjoyed by slaveholders existed and many residents demanded a resolution. But other political or constitutional issues had been resolved through the 1851 Constitution. "Western Virginia acquired great political power" with "the adoption of the new Constitution," the Kanawha Valley Star declared, removing the "feeling of political inequality" that had characterized intrastate sectional relations. Former opponents of slavery "now argue that African slavery...is a social, moral and political blessing," the newspaper averred, and those who had "desired a division of the State" had recanted their apostasy. The editor charged that a "hallucination" impaired Virginia Republicans from acknowledging these new developments. Whether "Whigs, Know-Nothings, or Democrats," northwesterners are "thoroughly imbued with States Rights' principles and are warmly attached to...the welfare of Virginia and the interests of

\footnotetext{
${ }^{77}$ Benjamin Henry Latrobe, Notices of Parkersburg, Virginia, as it is in July, 1860 (Baltimore: John W. Woods, 1860), 12.

${ }^{78}$ Daily Intelligencer, January 11, 1860, 2.
} 
the South," he concluded. The Northwest's political fissures that Republicans had hoped to exploit had been closed and the bonds between residents strengthened by Virginia's proslavery and democratic constitution. ${ }^{79}$

More political realities became manifest to Republicans during the 1859 gubernatorial election. Democrats and Oppositionists (a mixture of alienated Democrats, Know Nothings, and Whigs) fielded candidates for the state's third popularly-elected gubernatorial contest; no Republican ran for office. Oppositionists, meeting in Richmond in February 1859, nominated Bedford County attorney and planter William L. Goggin for governor and Monongalia County lawyer and slaveholder Waitman T. Willey for lieutenant governor. ${ }^{80}$ One northwestern Oppositionist exclaimed that Willey's nomination represented an "honor conferred...upon our section of the State and...County." 81 While Oppositionists statewide applauded their party's ticket, Democrats faced internal discord.

Following the death of Richmond Enquirer editor and state Democratic leader Thomas Ritchie in 1854, a power vacuum emerged in the Virginia Democratic Party. Governor Henry A. Wise and Senator R.M.T. Hunter both vied for the mantle of Democratic standard-bearer, generating an internecine conflict within their party. Hunterites supported Rockbridge County slaveholder and newspaper editor John Letcher while Wise and his backers opposed Letcher because of his endorsement of the Ruffner Pamphlet in $1847 .{ }^{82}$ Because Letcher believed that

\footnotetext{
${ }^{79}$ Kanawha Valley Star, September 22, 1857, 2. [emphasis in original]

${ }^{80} 1860$ U.S. Federal Census: Southern Revenue District, Bedford, Virginia; Roll: M653_1335; Page: 664; Image: 370; Family History Library Film: 805335; 1860 U.S. Federal Census - Slave Schedules, Southern Revenue District, Bedford, Virginia; and 1860 U.S. Federal Census - Slave Schedules, Monongalia County, Virginia [Ancestry.com][accessed 15 May 2015]

${ }^{81}$ Ralph L. Berkshire to Waitman T. Willey, 11 February 1859, Charles H. Ambler Collection, A\&M 122, Box 10, Folder 5, item 238, WVRHC. [emphasis in original]

${ }^{82} 1860$ U.S. Federal Census: Lexington, Rockbridge, Virginia; Roll: M653_1378; Page: 11; Image: 15; Family History Library Film: 805378 and 1860 U.S. Federal Census - Slave Schedules, Lexington, Rockbridge, Virginia [Ancestry.com][accessed 15 May 2015].
} 
"Western Virginia would be better off without than with negroes," a northwestern newspaper observed, "he is not fit for a Governor." ${ }^{83}$ Fairmont lawyer Francis H. Pierpont believed that "the 'negroocracy' of Virginia" advanced these arguments "as cogent reasons why Letcher should be defeated." 84 Though Letcher secured the party's nomination in December 1858, his previous stance on slavery threatened to derail his candidacy. ${ }^{85}$

Most northwestern Democrats supported Letcher, dismissing his endorsement of the Ruffner Pamphlet and highlighting his work in the previous constitutional convention. At a Democratic meeting in Harrison County, Democrats rejected eastern Virginians' accusations that Letcher was "unsafe" on slavery. Such accusations, which northwestern Democrats considered "unjust" and "calculated to excite a sectional feeling," generated the "erroneous belief abroad that Virginia is not a unit on the question of slavery." Letcher's "public life" and slaveholding status exhibited his "fealty to the Democratic party and the South," evidence that should placate eastern Virginians. Further, his "manly course" during the previous constitutional convention helped secure a democratic and proslavery constitution. Letcher was "now, and ever has been devoted" to the " "peculiar institution."

In an effort to boost his candidacy and quiet critics, Letcher penned an open letter where he once again abnegated his support of the Ruffner Pamphlet (something he had already done in 1850) and extolled his soundness on the issue of slavery. An "owner of slave property, by purchase and not inheritance," Letcher denied ever considering slavery a moral blight. He recanted his "erroneous" conclusions concerning slavery's detrimental political and economic

\footnotetext{
${ }^{83}$ Wheeling Daily Intelligencer, July 1, 1858, 2.

${ }^{84}$ Francis H. Pierpont to Waitman T. Willey, 16 March 1859, Charles H. Ambler Collection, A\&M 122, Box 10, Folder 5, item 242, WVRHC.

${ }^{85}$ Democrats selected Middlesex County lawyer and planter Robert L. Montague for lieutenant governor.

${ }^{86}$ Cooper's Clarksburg Register, November 12, 1858, 2.
} 
influences, condemned the "exceptional" arguments contained in the final version of the Ruffner Pamphlet, and candidly “acknowledged my error" in supporting its publication. Letcher's public apology revealed the deepening importance of slavery in the post-convention years. Since 1851, the slavery question "has been much better understood, not only in Virginia, but throughout the South" as slavery "has been discussed with an ability never before expended upon it." ${ }^{87}$ The ratification of the new constitution deepened residents' participation in the "politics of slavery" because the constitution placed slavery and whiteness at the center of all political discussions, a "revolution of public sentiment" according to Letcher. Any weakness or equivocation exhibited by politicians of any stripes concerning slavery or whiteness elicited censure and condemnation from residents across the state for their political independence and liberty hung in the balance.

Oppositionists doubted Letcher's sincerity. At their nominating convention in Richmond in early February 1859, Oppositionists denounced Letcher's “willingness to divide this ancient Commonwealth, for the purpose of exterminating slavery" in western Virginia. ${ }^{88}$ Oppositionists convening in Norfolk in January 1859 argued that Letcher's nomination "threatens the ultimate, if not speedy overthrow of African slavery." His support of the Ruffner Pamphlet, a document containing "sentiments more foully abolition than ever fell from the lips" of northern abolitionists, revealed Letcher's true character. ${ }^{89}$ Letcher's endorsement of the Ruffner Pamphlet coincided with the establishment of a "powerful party" that launches the "most bitter and determined assaults upon our institutions." This former endorsee of the Ruffner Pamphlet "now demands the suffrages of Virginia slaveholders for the office of their Chief Magistrate, the

\footnotetext{
${ }^{87}$ Quoted in To the People of Virginia! John Letcher and his Antecedents. Read and Circulate. (Richmond: Whig Book and Job Office, 1859), 6-7.

${ }^{88}$ Wheeling Daily Intelligencer, February 15, 1859, 2.

${ }^{89}$ The Ruffner Pamphlet and its Endorsers. Let Everybody read and Judge for Themselves. (Norfolk: Opposition Party of Norfolk, 1859), 3.
} 
conservator of their sectional rights, and guardian of their peculiar institution!"90 Protecting slavery required Virginians to move beyond party loyalty and prioritize the cornerstone of their state's political foundation. Though "party has ties and obligations," Oppositionists reminded Virginians that "state and sections had ties and obligations of a far higher, stronger, and a more sacred character." Norfolk Oppositionists encouraged all Virginians who supported slavery to endorse Goggin and defeat Letcher. ${ }^{91}$

This proslavery rhetoric found a receptive audience in the Northwest. Northwestern Oppositionists rhetorically questioned how residents could "conscientiously and patriotically vote for a man...who was... a foul-mouthed Abolitionist a few years ago."92 Letcher's endorsement of the Ruffner Pamphlet manifested his "unsoundness on the slavery question, and his consequent unfitness for" governor. ${ }^{93}$ Indeed, Letcher's alleged "abolitionism” was "killing him in every slave district" in eastern Virginia, an Oppositionist newspaper charged, forcing him to focus his campaign west of the Blue Ridge. But because slavery concerned all Virginians, Oppositionists maintained Letcher's prospects in the Shenandoah Valley, Southwest, and Northwest were equally as fleeting. ${ }^{94}$ Letcher's abolitionism was so apparent that Oppositionists predicted that he would receive the "anti-slavery vote in Northern and Northwestern Virginia bordering on Pennsylvania and Ohio." 95

While Oppositionists painted Letcher as "unsound" on slavery, their candidates burnished their proslavery credentials. In a speech in Wheeling, Willey stated his continued belief in the "principles that which had been enunciated at Richmond" in 1851, specifically that democratic

\footnotetext{
90 The Ruffner Pamphlet and its Endorsers, 4.

91 The Ruffner Pamphlet and its Endorsers, 5.

${ }^{92}$ Weekly Campaign [Clarksburg], April 18, 1859, 1.

${ }^{93}$ Weekly Campaign, April 11, 1859, 2.

${ }^{94}$ Weekly Campaign, April 18, 1859, 2 and Link, Roots of Secession, 172.

95 Weekly Campaign, April 18, 1859, 2.
} 
reform and increased protection for slavery secured the "best interests of the State and the nation." Willey considered this the "correct" position for all Virginians across the state. ${ }^{96}$ Oppositionists considered Willey's position on slavery as in "perfect propriety" with the "most rabid pro-slavery man in Eastern Virginia." 97 Indeed, Willey was "as true a Virginian, and as loyal a friend of slavery, and as staunch a Southern man, in all his impulses, principles, and purposes" as any Virginian east of the Blue Ridge. ${ }^{98}$ Goggin's record on slavery was "fair and untarnished" and his "soundness on [slavery] had never been called in controversy." "99 Banker and businessman Chester D. Hubbard characterized Goggin's speech in Wheeling as “very effective" and "gained [him] many friends," although Republicans denounced him because of his “slavery proclivities.” Hubbard dismissed Republicans' opinion of Goggin, characterizing the party as "only a corporal guard at best and more impracticable than the Democrats." Though the Republican Party persisted in the Northwest, its incremental growth and failure to field candidates or win numerous legislative seats convinced Hubbard and other northwesterners' that Goggin's proslavery speech, not Republicans' platform, defined Virginia politics. ${ }^{100}$

Slavery's increasing importance to Virginia's electoral politics once again became manifest. Oppositionists agreed with Letcher's assessment of the post-1851 years, arguing that the 1851 Constitution solidified slavery's centrality to politics and white men's political independence. "Slavery or anti-slavery," an issue that held "so little interest in our midst a few years since, has grown in consequence, in magnitude, [and] in momentousness," Oppositionists declared. Now, the "very soul and centre of our social compact and being" centered on African

\footnotetext{
${ }^{96}$ Wheeling Daily Intelligencer, April 7, 1859, 3.

${ }^{97}$ Unknown newspaper, no date, in Willey Diary, 71, Waitman Thomas Willey Diary, A\&M 3, WVRHC.

${ }^{98}$ Richmond Whig, n.d., reprinted in Willey Diary, 71, Waitman Thomas Willey Diary, A\&M 3, WVRHC.

${ }^{99}$ Weekly Campaign, May 9, 1859, 4 and Weekly Campaign, April 25, 1859, 4.

${ }^{100}$ Chester D. Hubbard to William Hubbard, 26 May 1859, Hubbard Family Papers, A\&M 805, WVRHC and 1860 U.S. Federal Census: Wheeling Ward 5, Ohio, Virginia; Roll: M653_1368; Page: 342; Image: 350; Family History Library Film: 805368 [Ancestry.com][accessed 18 May 2015]
} 
American bondage. ${ }^{101}$ Oppositionists and Democrats declared that their candidate and ideology protected slavery, secured slaveholders' rights, and defended whiteness for all white Virginians. These assertions were more than political rhetoric; they constituted the ruling political paradigm.

Republicans witnessing the election unfold mocked this spectacle of political cannibalization. The contest, which "hinge[d] on the everlasting nigger question," provided residents the choice of electing "tweedle-dum" or "tweedle-dee" to carry on the mission of the "ultra niggerites." 102 Democrats' and Oppositionists' monomania concerning slavery reflected Virginians' overwhelming interest in the peculiar institution, a dynamic Republicans lamented. "Its politics—its democracy—its constitutionalism," the Republican Wheeling Daily Intelligencer groaned, "and its [sic] all hangs and swings upon the idea of a universal nigger dominion." ${ }^{103}$ Those opposed to this political dynamic felt trapped. Northwestern political organs were "either too hopelessly bigoted or too fearful of being called Black Republican" to challenge this ruling political paradigm, the Wellsburg Weekly Herald charged. ${ }^{104}$ Anyone opposed to the prevailing "nigger interest" would be labeled an "abolitionist," "traitor," or “conspirator" by Democrats and Oppositionists. ${ }^{105}$ Though Republicans suggested that the "politics of slavery" had "played out" in the Northwest, they were mistaken; slavery dominated the gubernatorial contest. ${ }^{106}$

Letcher won the contest by approximately five thousand votes. This margin represented four thousand fewer votes than what Wise received in 1855, a result some Democratic partisans

\footnotetext{
${ }^{101}$ Weekly Campaign, April 25, 1859, 4.

${ }^{102}$ Wellsburg Weekly Herald, May 6, 1859, 2.

${ }^{103}$ Wheeling Daily Intelligencer, May 4, 1859, 2.

${ }^{104}$ Wellsburg Weekly Herald, May 6, 1859, 2.

105 Wheeling Daily Intelligencer, August 19, 1858, 2.

106 Wheeling Daily Intelligencer, April 22, 1859, 2.
} 
attributed to Letcher's former "free soil proclivities." 107 The slim margin also evoked concern from Democrats about their waning hegemony over state affairs. William Link argues that the gubernatorial contest, compounded with Democratic congressional losses in June 1859, "provided...evidence of the erosion of Democratic domination." Northwestern residents expressed "an anti-Democratic tradition" that opposed Democrats' proslavery platform and proslavery politics in general, he maintains. This waning Democratic support, Link contends, increased larger intrastate tensions concerning African American bondage and provided an opening for Republicans to exploit. ${ }^{108}$

Anti-Democratic politics in the Northwest, though, did not represent antislavery politics. The 1859 gubernatorial contest featured two proslavery candidates and passionate debates among partisans on both sides who extolled their party's sound position on slavery. Much to Republicans' chagrin, the election failed to show residents' waning fealty toward slavery; rather, the election reaffirmed slavery's centrality to politics and residents' worldview. Further, the continued viability of a second party in the Northwest reflected a continuation of politics that had commenced during the 1820s and 1830s. The establishment of these two parties also inaugurated the "politics of slavery," and this brand of southern politics continued to dominate the political landscape. Finally, the gubernatorial election confirmed residents' political affiliation. Traditional Democratic counties, such as Monongalia, Preston, Harrison, and Marion returned majorities for Letcher; Marshall, Ohio, Kanawha, and Wood, all Whiggish counties,

\footnotetext{
${ }^{107}$ B. Wilson to Jonathan M. Bennett, 31 May 1859, Jonathan M. Bennett Papers, A\&M 32, Box 17, item 6009, WVRHC and Figures drawn from "Table 5.1 The Democratic Majority in the Gubernatorial election of 1859," in Link, Roots of Secession, 174.

${ }^{108}$ Link, Roots of Secession, 175-176. Other historians echo Link's interpretation. Charles Ambler labeled Letcher's triumph over Goggin a pyrrhic victory, claiming that Letcher "owed his election to his former utterances in favor of abolition and the anti-slavery sentiment of the west." Ambler, Sectionalism in Virginia, 324-325. Further, the political divisions in Virginia mirror the cleavages that William Freehling argues hampered a unified South from moving in lockstep, and revealed important opposition to slavery and to the eventual formation of the Confederacy. Freehling, Road to Disunion: Secessionists Triumph.
} 
supported Goggin. ${ }^{109}$ The electoral patterns exhibited in the 1859 gubernatorial election confirmed Oppositionists’ observation: slavery dominated politics.

Slavery dominated northwesterners' political worldview and took on greater importance in the wake of John Brown's raid at Harpers Ferry on October 16, 1859. Brown's audacious plan stoked fears among slaveholding Virginians about their nonslaveholding neighbors' fealty, notably those along the state's northern and western borders. But northwesterners' condemned the raid, labeling Brown a northern abolitionist radical and a possible harbinger of future conflict over slavery. A Parkersburg resident characterized the raid as "evidence of the intense fanaticism which exists among some persons on the subject of slavery." "[J]ustice" would be brought to bear on the "ringleaders" of this raid, a Parkersburg newspaper predicted, as they would "scarcely escape hanging." 110 Preston County locomotive engineer Patrick Plummer considered the "insurrection" the work of "Black Republicans," but noted that Brown met his fate at the gallows. ${ }^{111}$ Lewis County attorney Joseph Spalding supported Governor Wise's aggressive response to Brown's raid, applauding his stance despite the "threats or imprecations" from the "friends and sympathizers of these blood stained emissaries of Black Republicanism." 112 The Republican Wheeling Daily Intelligencer also condemned this "suicidal" attack from a "fanatical renegade."113 But the raid could turn public opinion in favor of colonization, Virginia Republicans hoped. A "large and degraded class of humanity" resided within Virginia and appeared poised to revolt against white Virginians, Republicans erroneously

\footnotetext{
${ }^{109}$ Kanawha Valley Star, June 21, 1859, 2.

${ }^{110}$ Parkersburg News, October 18, 1859, 2.

${ }^{111}$ Patrick Plummer Diary, A\&M 2772, WVRHC and 1860 U.S. Federal Census: Newburg, Preston, Virginia; Roll: M653_1372; Page: 250; Image: 256; Family History Library Film: 805372 [Ancestry.com][accessed 19 May 2015]

112 Joseph Spalding to Jonathan M. Bennett, 11 November 1859, Jonathan M. Bennett Papers, A\&M 32, Box 17, item 6316, WVRHC and 1860 U.S. Federal Census: Weston, Lewis, Virginia; Roll: M653_1358; Page: 187; Image: 195; Family History Library Film: 805358 [Ancestry.com][accessed 22 May 2015]

${ }^{113}$ Wheeling Daily Intelligencer, October 19, 1859, 2.
} 
speculated. Much like San Domingo and Southampton, Harpers Ferry should remind Virginians that an "irruption" threatened to decimate society. ${ }^{114}$

This "irruption" could be prevented, Virginia Republicans maintained, by electing Abraham Lincoln for president in November 1860. For decades, the national government had operated like a "machine for the propagation of the institution of slavery" by increasing the number of slaves and augmenting slaveholders' power while the 1851 Constitution induced Virginians into "ten years sleep" by providing democratic reforms but enslaving white men. ${ }^{115}$ But Lincoln would prohibit the extension of slavery into the territories, protect the interests of white laborers, and defeat the national "Slave Power." And as the national "Slave Power" withered, the Virginia "Slave Power" would weaken, too. Virginia Republicans believed that his election would accelerate the party's growth. As one national Republican predicted, Lincoln's "triumph...would give the cause of Free Soil a powerful propulsion" in the Old Dominion and "in all the border slave states." In a few years, Virginia Republicans could secure a "free soil balance of power" over state politics that would soon liberate Virginia from the "incubus" of slavery. White Virginians would finally be freed from the "Slave Power."116

Republicans envisioned a whole sequence of political and social changes that would flow from Lincoln's victory. The “unequal and unfair operation of pro-slavery legislation upon Western Virginia" would be stymied, specifically the constitutional provision exempting full taxation on slaves and the continued use of the "mixed basis" to determine state Senate apportionment. ${ }^{117}$ The "gradual emancipation sentiment" that had long existed among residents

\footnotetext{
${ }^{114}$ Wheeling Daily Intelligencer, October 21, 1859, 2.

115 Wellsburg Weekly Herald, September 28, 1860, 2 and Daily Intelligencer, February 13, 1860, 2

116 J. Medill to Archibald Campbell and John McDermot, 30 October 1859, Archibald W. Campbell Papers, A\&M 14, Box 1, Folder 2: April-November 1859, WVRHC.

${ }^{117}$ Daily Intelligencer, April 7, 1860, 2.
} 
would soon "triumph." Slavery's demise in the Northwest manifested the "order of nature" and “fate itself," finally freeing residents to pursue closer relations with their northern neighbors. ${ }^{118}$ The Northwest's “free laboring white men” would experience liberation from the state's slaveholding "Olegarchy." For decades, this slaveholding cabal "aim[ed] for the destruction of all the industrial interests of Western Virginia," sanctioned the construction of "railroad and other public improvements" east of the Blue Ridge, and considered white northwesterners "more subservient to their interest and dictation than the degraded African." The "sacred guarantees of Constitutional liberties" extended to white northwesterners in exchange for their political submission only strengthened this "Olegarchy."119 The "mighty movement" of Republicanism would soon instigate a "radical change in our organic laws" that would liberate white northwesterners and destroy the "Slave Power."120

Though the confidence expressed by Republicans ran counter to political developments in the Northwest over the previous decades, Republicans believed they could politicize the intrastate animosity that existed in the state. But Republicans' sanguine outlook contained numerous flaws. Republicans often exaggerated their numerical strength, admitting that the majority of their strength, "with few exceptions, reside in the Panhandle" and the "great bulk of them in [Wheeling]."121 Taylor County farmer Fabricius A. Cather attended a "Republican poleraising" in late September 1860 but noticed the lackluster attendance, noting "[n]ot a very large turnout" for this Republican gathering. ${ }^{122}$ John G. Jacob, editor of the Republican Wellsburg Weekly Herald, understood the party's challenge to building a grassroots movement. Jacob

\footnotetext{
118 Daily Intelligencer, February 29, 1860, 2.

119 Daily Intelligencer, May 23, 1860, 2.

${ }^{120}$ Daily Intelligencer, April 25, 1860, 2.

${ }^{121}$ Daily Intelligencer, April 25, 1860, 2.

122 Diary entry, September 21, 1860, Fabricius A. Cather Civil War Diaries, A\&M 3633, WVRHC.
} 
"[e]ncourage[d] ...outsiders...to break through the shackles" while Virginia Republicans "put in an occasional modest lick." 123 Jacob blamed the epithet "Black Republicanism" for suppressing Republican membership, finding it "difficult to induce men to subscribe their names" to Republican organs. ${ }^{124}$

Republicans also faced difficulties in overcoming northwestern residents' established political affiliations. For over three decades, Democrats, Whigs, Americans, or Oppositionists courted voters with well-defined and accepted ideological platforms based on protecting slavery and whiteness. Attracting an electorate would be difficult for Republicans, notably because of the party's association with some avowed antislavery politicians and abolitionists. As one Democratic newspaper declared, Virginia Republicans worked with "that greasy, manumitted African, Fred Douglas," a relationship that would compel its members to support racial equality. ${ }^{125}$ Though Republicans claimed to protect the interests of white men through "free labor" and "free soil," northwestern residents believed that protecting slavery offered the best defense of whiteness. Republican doctrines, conversely, appeared to threaten whiteness.

The 1860 presidential election demonstrated northwesterners' concern for protecting slavery and whiteness. Four candidates vied for the White House, including two Democrats. Southern Democrats had walked out of the national convention after northern delegates refused to support a plank that would have protected slave property in all territories. The remaining Democrats nominated Illinois Senator Stephen Douglas. Douglas, an exponent of "popular sovereignty" in the territories, represented the only nomine who could prevent the "Black

\footnotetext{
${ }^{123}$ John G. Jacob to Archibald W. Campbell, Archibald W. Campbell Papers, A\&M 14, Box 1, Folder 3: January April 1860, WVRHC.

${ }^{124}$ John G. Jacob to Archibald W. Campbell, Archibald W. Campbell Papers, A\&M 14, Box 1, Folder 3: January April 1860, WVRHC.

${ }^{125}$ Cooper's Clarksburg Register, July 16, 1858, 2.
} 
Republicans" from destroying the Union, a Fairmont supporter declared. ${ }^{126}$ Though "[s]outhern papers" questioned "Douglas' peculiar dogma," the Little Giant's doctrine of "popular sovereignty" provided stability and security for slaveholders and nonslaveholders alike. Douglas' "popular sovereignty" also separated him from the notorious "free-soil party" that sought slavery's extinction. ${ }^{127}$

Douglas' national appeal made him a more viable candidate than his Democratic counterpart, John C. Breckinridge of Kentucky. Douglas Democrats maintained that Breckinridge represented the "Seceders" and supported a "sectional party" that would repel northern voters. ${ }^{128}$ Wheeling banker Chester D. Hubbard considered Douglas the "stronger" Democratic candidate "in this part of the state," predicting that the Illinois Senator would "poll two votes to his [Breckinridge] one." ${ }^{129}$ Hubbard was sanguine about Douglas' electability because his platform protected white men's interests. Following a Douglas rally, white laborers paraded the streets of Wheeling while they displayed their trade tools. The "bricklayer with his trowel and a wheelbarrow full of bricks, the blacksmith with his hammer and tongs, [and] the carpenter with his saw and adze" endorsed Douglas because unlike his opponents, the Little Giant championed the interests of white men. ${ }^{130}$

Vice President John C. Breckinridge was the other Democratic nominee. Breckinridge supporters characterized Republicans and their other opponents as unsound on slavery, the seminal issue of the election. Republicans "favor[ed]...negro equality," Breckinridge partisans declared, and "wanted to free all the negroes who would come in competition with the white

\footnotetext{
${ }^{126}$ Virginia Weekly Star [Morgantown], August 30, 1860, 2.

${ }^{127}$ Virginia Weekly Star [Morgantown], August 30, 1860, 2. [emphasis in original]

${ }^{128}$ Virginia Weekly Star, August 30, 1860, 2.

${ }^{129}$ Chester D. Hubbard to William Hubbard, 17 September 1860, Hubbard Family Papers, A\&M 805, WVRHC.

${ }^{130}$ Daily Intelligencer, August 30, 1860, 3.
} 
laborer, and by working for low wages make hard times among the white folks." The "Republican Party is not the white man's party" while Breckinridge "was the true friend of the laboring white man." Breckinridge supporters considered Douglas' doctrine of popular sovereignty "as not much better than the Lincoln doctrine in regard to the territories." Northerners' alleged superior mobility meant that they "could gather their little dunnage in a bandana handkerchief and with a few clocks...hurry into a new territory and make a patent free state in three months." Popular sovereignty forecasted doom for white southerners, Breckinridge Democrats argued. Douglas' plan amounted to southern submission to northerners; white southerners who cherished their constitutional rights to take their property into the territories needed to endorse Breckinridge. ${ }^{131}$

Though Breckinridge enjoyed widespread support throughout the Deep South, his prospects in western Virginia were equally encouraging. One Barbour County resident argued that the "Northwest is for Breckinridge \& Lane." So confident was this resident in Breckinridge's prospects that he chastised eastern Virginians for their lukewarm support for him. "Are they all teeming Free Soilers" east of the Blue Ridge? "[I]f so, let them go, as the Northwest has more than once saved the Democratic party." 132 Western Virginians needed to endorse Breckinridge because his platform championed African American bondage, the wellspring of white men's political independence. "Negro slavery protects the white laborers' interests," maintained one western Virginia Breckinridge organ, as slavery placed the "white laborer in the south...upon a perfect equality with his employer." A Republican victory would

\footnotetext{
${ }^{131}$ Daily Intelligencer, September 5, 1860, 3.

132 A.G. Ryer to Jonathan M. Bennett, 2 August 1860, Jonathan M. Bennett Papers, A\&M 32, Box 19, item 6742, WVRHC.
} 
upset that hierarchy. Only a Breckinridge victory could prevent that calamity from unfolding, a dire situation for all white Virginians. ${ }^{133}$

Former Whigs continued to be a potent political force in 1860, reorganizing as the Constitutional Union Party and nominating Tennessean John Bell for president and Massachusetts politician Edward Everett for vice president. Bell and his supporters proclaimed that the Constitution contained the remedy for the ills that afflicted the republic. The rights of slaveholders, Constitutional Unionists declared, were safer in the Union and under the Constitution where their grievances could be redressed and the power of the Constitution compelled northerners to respect southerners' constitutional rights. This message found wide acceptance in the Northwest. Taylor County newspaper editor Daniel S. Morris "expect[ed] to fight hard for Bell and Everett," while Constitutional Unionists in Upshur County reported that "Bell and Everett poles are going up all over the [c]ounty." 134 Wheeling insurance agent Nathaniel C. Arthur noted that the "Bell \& Everett stock" was "on the increase here and is increasing everywhere." 135

Bell's popularity reflected white northwesterners' belief that Bell, unlike his opponents, provided white northwesterners the greatest economic and political security. Kanawha County slaveholder George W. Summers warned northwesterners that a Breckinridge administration would reopen the African slave trade, a practice that "would ruin the slave interests of

\footnotetext{
${ }^{133}$ Independent Democrat [Charles Town], July 31, 1860, 2.

${ }^{134}$ Daniel S. Morris to Waitman T. Willey, 11 July 1860, Charles H. Ambler Collection, A\&M 122, Box 10, Folder 6, item 274, WVRHC; 1860 U.S. Federal Census: Taylor, Virginia; Roll: M653_1381; Page: 507; Image: 11; Family History Library Film: 805381 [Ancestry.com][accessed 22 May 2015]; and Executive Committee Union Club [J.D. Rapp, E.J. Colerider, F. Berlin, G.W. Berlin, and W.H. Gibson] to Waitman T. Willey, 30 August 1860, Charles H. Ambler Collection, A\&M 122, Box 10, Folder 6, item 281, WVRHC.

${ }^{135}$ Nathaniel C. Arthur to Jonathan M. Bennett, 6 September 1860, Jonathan M. Bennett Papers, A\&M 32, Box 19, item 6809, WVRHC and 1860 U.S. Federal Census: Wheeling Ward 3, Ohio, Virginia; Roll: M653_1368; Page: 198; Image: 206; Family History Library Film: 805368 [Ancestry.com][accessed 22 May 2015].
} 
Virginia." 136 Wheeling lawyer and slaveholder A.B. Caldwell "convict[ed] the Republican Party of Abolitionism and Sectionalism," noting the presence of few southern Republicans. Without a southern wing, he inferred, northern Republicans could declare war on slavery. ${ }^{137}$ Randolph County lawyer and slaveholder David Goff, a Bell supporter, believed the contest to be between "Bell \& Lincoln." The "whole south should unite...in order to defeat black republicans." 138 In Wheeling, Waitman Willey emphasized the danger of a Republican president. Willey predicted "hordes of free negroes running loose here amongst us freemen, and competing in labor with our honest artizans." ${ }^{139}$ During a meeting, Constitutional Unionists declared their nominee's "allegiance to support [southern] institutions... and [that] the North and the Republican party" should not meddle in southern affairs. White southerners could rest assured that Bell would secure their interests. ${ }^{140}$ Such fealty toward the Constitution and to slavery provided "every assurance" to Chester Hubbard that Bell would carry Virginia. ${ }^{141}$

Virginia Republicans attempted to engage in the "politics of slavery" but with mixed results. Republicans championed "loyalty to party, loyalty to State, [and] loyalty to Southern institutions," uttering "not a single word in derogation of such a sentiment." Yet many Republicans also considered this unquestioned loyalty "political suicide" and characteristic of the "empty ideas of Southern society." 142 In a Republican meeting in Hancock County,

\footnotetext{
${ }^{136}$ Daily Intelligencer, October 1, 1860, 3 and 1860 U.S. Federal Census - Slave Schedules, Kanawha County, Virginia [Ancestry.com][accessed 22 May 2015].

${ }^{137}$ Daily Intelligencer, August 13, 1860, 3; 1860 U.S. Federal Census: Wheeling Ward 3, Ohio, Virginia; Roll: M653_1368; Page: 197; Image: 205; Family History Library Film: 805368 [Ancestry.com][accessed 22 May 2015]; and, 1860 U.S. Federal Census - Slave Schedules, Ohio County, Virginia [Ancestry.com][accessed 22 May 2015]. ${ }^{138}$ David Goff to Caleb Boggess, Jr., 9 October 1860, Gideon D. Camden Collection, A\&M 1199, Box 6A, Folder July 1860 to October 1860, WVRHC; 1860 U.S. Federal Census: Randolph, Virginia; Roll: M653_1374; Page: 109; Image: 122; Family History Library Film: 805374 [Ancestry.com][accessed 22 May 2015]; and, 1860 U.S. Federal Census - Slave Schedules, Randolph County, Virginia [Ancestry.com][accessed 22 May 2015].

${ }^{139}$ Daily Intelligencer, October 3, 1860, 3.

${ }^{140}$ Daily Intelligencer, July 16, 1860, 3.

${ }^{141}$ Chester D. Hubbard to William Hubbard, 17 September 1860, Hubbard Family Papers, A\&M 805, WVRHC.

${ }^{142}$ Wellsburg Weekly Herald, August 17, 1860, 2.
} 
Republicans stressed that "we are loyal to the constitution and laws of our own state... and ready...to defend our institutions and soil from invasion of fanatics." Further, northwestern Republicans' "fealty and kindness to the State of Virginia and to our Eastern brethren" was unmatched. But these Republicans also condemned the "Constitutional wrongs and Legislative enactments of this Commonwealth," labeling them a "stain" on the state's dignified history. Republicans' pronouncements concerning slavery obfuscated their message of "free labor" and “free soil," casting further doubt about their party’s political motives. ${ }^{143}$

While Republicans struggled to navigate "politics of slavery," they emphasized their overwhelming concern for whiteness, an important interest for white northwestern laborers. Republicans manifested their advocacy of whiteness by holding rallies and meetings at northwestern industries, notably iron mills. This appropriation of the Northwest's industrial context held deep political meaning. Since the 1820 s and 1830 s, courthouses represented the locus and projection of state power and white men's political independence and liberty. ${ }^{144}$ Both Democrats and Whigs appropriated the courthouse during election season to manifest their party's defense of whiteness and white men's political privileges. Republicans envisaged the Northwest's industries commanding the same political and cultural significance as the courthouse. Labor generated self-worth, dignity, and independence in white men, important virtues that carried over into politics. The state no longer represented the source of political independence for white men, generating greater distance between the laborer and the values and institutions that shaped the state. The "four hundred people" in attendance at a Republican meeting at La Belle Rolling Mill in Wheeling celebrated more than the Republican ticket or the

\footnotetext{
${ }^{143}$ Daily Intelligencer, March 31, 1860, 1.

${ }^{144}$ Laura F. Edwards, The People and their Peace: Legal Culture and the Transformation of Inequality in the PostRevolutionary South (Chapel Hill: University of North Carolina Press, 2009).
} 
employment provided by the mill; they manifested their political independence. These attendees "will be found voting the glorious Republican ticket," the Daily Intelligencer reported, as these men considered labor the wellspring of their political independence. ${ }^{145}$

Virginia Republicans understood the challenges they faced heading into the presidential election. To mobilize northwestern voters, Republicans encouraged the formation of Wide Awake organizations and held numerous pole raisings throughout the region. Republicans hoped that these civic functions would "stir up a spirit of enthusiasm and secure a full turn out of the Republican strengthen of the city at the election." ${ }^{146}$ Wheeling Germans often enrolled as Wide Awakes, a paramilitary organization that courted young voters and encouraged political participation. ${ }^{147}$ Members held the proceedings and adopted a Constitution in German, often inviting the "German public...to attend" these gatherings. ${ }^{148}$ Republicans also held pole raisings throughout the region and extended invitations to "any of the friends of Lincoln." The attendance of Republican neophytes during these gatherings offered a clear signal to northwestern Republicans of their party's ascendency and popularity. ${ }^{149}$

\footnotetext{
${ }^{145}$ Daily Intelligencer, August 6, 1860, 3. See also Daily Intelligencer, August 4, 1860, 3. Though Republicans attempted to appropriate the Northwest's industrial context for political purposes, they held political meetings and rallies at local courthouses, too, another signal that southern values continued to guide politics in 1860.

${ }^{146}$ Daily Intelligencer, August 29, 1860, 3.

147 Jon Grispan, “'Young Men for War': The Wide Awakes and Lincoln's 1860 Presidential Campaign," Journal of American History, 96, no. 2 (September 2009): 357-378.

${ }^{148}$ Daily Intelligencer, September 8, 1860, 3 and September 16, 1860, 2. For another example of German Republican political involvement, see Daily Intelligencer, October 29, 1860, 3. The strength of the Republican Wide Awakes may have been exaggerated by Republican organs. Republicans from Pittsburgh often augmented Wide Awake ranks, a signal that the epithets and abuses directed toward them impeded membership. For example, some partisans labeled Wide Awakes as a "continuation of John Brown's brilliant scheme to abolitionize the South" and considered them "'Nigger thieves,' 'Wooley heads,' 'Abolitionists,' and every species of opprobrious epithets." See Daily Intelligencer, September 25, 1860, 3, October 5, 1860, 3, October 12, 1860, 3, October 13, 1860, 3, and November 6, 1860, 2 and Wellsburg Weekly Herald, October 5, 1860, 2.

${ }^{149}$ Daily Intelligencer, July 24, 1860, 2. Much like Wide Awakes, pole raisings also generated conflict between Republicans and northwestern residents who disagreed with Republican principles. For example, following a pole raising in Hancock County, the Wellsburg Weekly Herald later reported that a "poor, miserable thing, in the shape of a man, felled our pole to the ground." Wellsburg Weekly Herald, September 28, 1860, 2.
} 
On the election's eve, Republicans expressed optimism about their electoral chances in the Northwest. Many Republicans appeared "in good spirits" as they looked ahead toward a "bright, political sky before them." 150 Hancock County farmer Abraham Pittenger remarked that the "Rail Splitter has lots of friends here."151 Republicans received further encouragement with news that Francis Pierpont was "stirring up the sovereigns in the mountain counties," showing residents slaveholders' tax receipts and the exemptions the state provided them. ${ }^{152}$ As Republicans argued during their state convention in Wheeling, the "non-Slaveholding farmers, mechanics and workingmen of Western Virginia" had been "oppressed and weighed down with taxation for the benefit of Eastern Virginia Slave capitalists.” But Lincoln's election would represent a watershed moment in the state's history. ${ }^{153}$ "The great cause of free labor, free speech, and free homesteads" would encourage northwesterners to elect Abraham Lincoln, the "champion of all their best hopes." 154

Even if Lincoln failed to carry Virginia, the votes northwesterners cast for him would represent a stinging rebuke to eastern slaveholders. Northwesterners "should vote for Lincoln and Hamlin... because they have been told in some quarters that they would not be allowed to vote that ticket." Such a denial fed Republicans' arguments that the "Slave Power" despised and manipulated democracy and would prevent white men from choosing the candidate of their choice. "The right to vote as a man pleases is the very corner stone of free institutions," Republicans declared, and a vote for Lincoln would illustrate northwesterners" "independence” and "their abhorrence of the treasonable sentiments of the secession democracy." Ballot by

\footnotetext{
${ }^{150}$ Daily Intelligencer, November 6, 1860, 3.

${ }^{151}$ Abraham Pittenger to Friends, 23 August 1860, Pittenger Family Papers, A\&M 3127, WVRHC; 1860 U.S. Federal Census: Hancock, Virginia; Roll: M653_1349; Page: 977; Image: 507; Family History Library Film: 805349 [Ancestry.com][accessed 26 May 2015] [emphasis in original]

${ }^{152}$ Fairmont True Virginian, November 10, 1860, 2; and, Wellsburg Weekly Herald, April 20, $1860,2$.

${ }^{153}$ Daily Intelligencer, May 5, 1860, 2.

${ }^{154}$ Daily Intelligencer, September 8, 1860, 2.
} 
ballot, Republicans would defeat the "Slave Power" and achieve political liberation for white northwesterners. ${ }^{155}$

The election returns demonstrated that Republicans still operated on the Northwest's political margins. Constitutional Union candidate John Bell narrowly carried the state over Democrat John C. Breckinridge by a few hundred votes. Lincoln failed to win the state or a single county, even in the supposed fertile soil of the Northwest or northern panhandle. While Republicans captured the White House, his vote total in Virginia illustrated his party's limited appeal. Lincoln received 1,929 votes or approximately $1.2 \%$ of all ballots cast statewide; both the aggregate and the percentage represented increases from Frémont's candidacy four years earlier. ${ }^{156}$ Yet Republicans failed to win a single county, even though Democrats offered a split ticket. Lincoln performed well in Hancock and Brooke counties; both counties, though, supported Breckinridge. In Ohio County, Lincoln finished just ahead of Douglas but still two hundred votes short of Breckinridge and five hundred votes behind Bell. ${ }^{157}$ What accounts for these voting patterns and Republicans' continued poor showing?

Republicans pinpointed the continued operation of the viva voce method of balloting but those prevented from voting for Lincoln would not have been enough to swing a count in his favor. Entrenched political affiliations continued to frustrate Republicans who failed to dislodge residents from their party loyalties. Traditionally Democratic counties once again provided important majorities for Breckinridge or Douglas, with Brooke, Hancock, Harrison, Lewis, Marion, and Preston counties all supporting the former. Monongalia County was one of the few across the state that Douglas carried. Over fifty-percent of northwestern voters supported

\footnotetext{
155 Wellsburg Weekly Herald, November 2, 1860, 2.

156 These figures are found in Tarter, Grandees of Government, 199.

${ }^{157}$ Parkersburg News, December 13, 1860, 2. Other northwestern counties casting ballots for Lincoln included Mason (58); Preston (110); Ritchie (12); and Wood (81).
} 
Democratic candidates. ${ }^{158}$ Whiggish northwestern counties, including Kanawha, Marshall, and Ohio, supported Bell. ${ }^{159}$ These partisan affiliations had remained relatively stable since the 1820s, an important roadblock Republicans failed to remove prior to the election.

The campaign revealed residents' continued deep engagement in the "politics of slavery." Whiteness and the protection of slavery represented the central issues of the election and all four parties cast their candidate as the "safest" choice for voters. Democrats and Constitutional Unionists experienced little difficulty in this political practice; Republicans, though, found it difficult to navigate the latter. While Republicans cast their party as the "white man's party," their membership included some antislavery politicians and even a few abolitionists. How could a party associated with such "radicals" truly protect white Virginians' interests? Republicans, unable to provide a sufficient answer for such a question, failed to significantly increase its northwestern membership. No party or politician in Virginia could succeed without finding the right answer to this question.

Northwesterners' expressed disappointment with Lincoln's election but recognized that his administration could do little to interfere with African American bondage. Fairmont Clerk of the Circuit Court Thomas G. Watson "acknowledge[d] the election of Lincoln...but it goes hard" among his Marion County neighbors. ${ }^{160}$ Chester Hubbard maintained that "Mr. Lincoln can not move a step... and will be checkmated at every turn" if he attempted to interfere with slavery in Virginia or across the South. If Lincoln "stands by the Constitution with all its compromises and enforces the laws," Virginia's institutions would be secured. ${ }^{161}$ Monongalia farmer William

\footnotetext{
${ }^{158}$ Figures from Table 6.1 "Votes for Presidential Candidates in the Election of 1860," Link, Roots of Secession, 208.

${ }^{159}$ Parkersburg News, December 13, 1860, 2.

${ }^{160}$ Thomas G. Watson to ?, 8 November 1860, Gideon D. Camden Collection, A\&M 1199, Box 6A, Folder November 1860 to February 1861, WVRHC and 1860 U.S. Federal Census: District 4, Marion, Virginia; Roll: M653_1361; Page: 576; Image: 136; Family History Library Film: 805361 [Ancestry.com][accessed 26 May 2015]. ${ }^{161}$ Chester Hubbard to William Hubbard, 10 November 1860, Hubbard Family Papers, A\&M 805, WVRHC.
} 
Price, who, though he opposed Lincoln's election “with all my might and advocated that of Bell as strenuous," found no constitutional grievance with Lincoln "until he commits some unconstitutional act."162 At a meeting in Triadelphia, residents "regret[ted] his success" and "emphatically denounce the cardinal principles of the party which elevated him to power," but considered Lincoln's election as "prescribed by law." Northwesterners would accept his administration until he "clearly violates their constitutional rights." 163 Though many northwesterners deplored Lincoln's election, most believed that the Constitution and the federal government's system of checks and balances would restrain his administration from meddling with Virginia's peculiar institution. Slavery in Virginia would continue to thrive under the Stars and Stripes.

Virginia Republicans celebrated Lincoln's election, interpreting it as a transformative moment in Virginia politics. "The aristocracy of niggerdom will no longer be dominant," the Wheeling Daily Intelligencer exclaimed. Northwestern voters would no longer be shackled to the Richmond "Slave Power," subordinating their interests to those of "Eastern Virginia's nigger interest." Residents would be unafraid to elect officials "for their soundness on our own interests" rather than "being selected for their soundness on the nigger."164 And with "Republicanism...the growing element...in Western Virginia," the political calculus in the state would never be the same. Soon, Republicans would inaugurate a true ad valorem tax, commence construction on internal improvements west of the Blue Ridge, achieve equal representation in

\footnotetext{
162 William Price to Michael Price, 26 December 1860, Box 1, William Price Papers, A\&M 1809, WVRHC and 1860 U.S. Federal Census: District 6, Monongalia, Virginia; Roll: M653_1364; Page: 255; Image: 267; Family History Library Film: 805364 [Ancestry.com][accessed 26 May 2015].

163 Daily Intelligencer, January 24, 1861, 1.

${ }^{164}$ Daily Intelligencer, November 9, 1860, 2.
} 
both state houses, and unleash the economic power of western Virginia. These changes in state and constitutional policies would hasten the collapse of the Virginia "Slave Power." 165

While northwesterners formulated two different interpretations concerning Lincoln's election, other white southerners interpreted his election as the death knell of the Union. South Carolina seceded in the wake of Lincoln's election, with Mississippi, Florida, Alabama, Georgia, Louisiana, and Texas following the Palmetto State's action in January and February 1861. The dissolution of the Union and the subsequent formation of the Confederate States of America initiated meetings and debates across the Northwest concerning Virginia's future. Most meetings evinced residents' determination to resist secession and remain in the Union. Hancock County residents maintained that they "can remain loyal to both" the United States and Virginia, arguing that their institutions depended on the Old Dominion remaining in the Union. These gatherers also assured "our Eastern brethren" that "their fears are groundless and arise from a misapprehension of the intentions of our Northern brethren." As "long as they remain faithful to our State and Union," Hancock County residents would use "our best efforts" to secure "their just rights, and labor with them for their enforcement." Bound by a shared goal, Virginians in all regions of the state would protect slavery and slaveholders' prerogatives. ${ }^{166}$

Similar meetings in Wheeling, Wellsburg, and Preston County manifested northwesterners' belief that remaining in the Union provided the greatest security for slavery and slaveholders. Most residents supported the Crittenden Compromise as a "final compromise of the vexed question of slavery," arguing that this constitutional "remedy" would resolve "any and

\footnotetext{
165 Daily Intelligencer, November 12, 1860, 2 and William W. Freehling, The Reintegration of American History: Slavery and the Civil War (New York: Oxford University Press, 1994), 213.

166 Daily Intelligencer, January 26, 1861, 4.
} 
all aggressions."167 Democratic Congressman Sherrard Clemens maintained that the U.S.

Constitution provided Virginia "greater protection than she will ever obtain" in the

Confederacy. ${ }^{168}$ Waitman Willey recounted how the "Northern press and pulpit" had

"persistently assailed" African American bondage, and believed that such abuses by northerners "ought to excite indignation and do demand resistance" from white northwesterners. But the federal government had always acted faithfully toward slaveholders, providing protection and ensuring the recapture of fugitive slaves and would mitigate this conflict. "What infraction of Southern rights has the General Government ever committed? Can any Southern man find any defection here?" Willey found it equally "remarkable...that Northern Presidents have always been faithful to Southern rights" and believed that Lincoln could do little to interfere with slavery. Secession, a "degrading" action and a "virtual acknowledgement of southern inferiority and inability to maintain her rights and vindicate her character," would threaten African American bondage. Slavery would continue to thrive under the federal government and Constitution. ${ }^{169}$

Not all white northwesterners, though, agreed that the Union would continue to protect slavery. In a meeting in Ritchie County, residents denounced the "spirit and legislation of Black Republicanism in the North, the unconstitutional enactments of the Northern States, and the denial of equal rights in the territories." How would remaining in the Union resolve these grievances? While residents "deprecate[d] disunion," Virginia should secede if northern states continued to deny white southerners "equal right[s]."

\footnotetext{
${ }^{167}$ Kingwood Chronicle, February 2, 1861, 3, Daily Intelligencer, January 21, 1861, 3, Daily Intelligencer, January 24, 1861, 1, and Wellsburg Weekly Herald, January 11, 1861, 2.

${ }^{168}$ Sherrard Clemens to Archibald W. Campbell, 23 January 1861, Archibald W. Campbell Papers, A\&M 14, Box 1, Folder 5: January - June 1861, WVRHC.

${ }^{169}$ Western Virginia Guard [Clarksburg], undated, reprinted in Waitman Thomas Willey Diary, Volume 1, 91-92, A\&M 3, WVRHC.

${ }^{170}$ Parkersburg News, January 24, 1861, 2.
} 
similar grievances. The "nullifying action of Northern States" and the "encroachments of the North upon our rights" provided enough evidence for these Wood County residents that only secession could secure their constitutional rights. ${ }^{171}$ During a public meeting in Gilmer County, residents denounced the actions "fanatical, sectional Black Republican[s]" who have "arrogated to themselves the dangerous privilege of interfering... with our domestic institutions." How could northwesterners trust northern Republicans who labored for slavery's "ultimate extinction"? ${ }^{172}$ The Fairmont True Virginian reminded residents that "Virginia claims your allegiance," an important reminder considering that Lincoln possessed the "power...to force you to be a butcher of your own brethren." Aggression against any slaveholding state should compel Virginians to defend their fellow southerners. ${ }^{173}$

Residents' disagreements concerning Virginia's future in the Union reflected disputes about the Northwest's future if the Old Dominion joined the Confederacy. Republicans maintained that Virginia's secession would justify residents' pursuit of dismemberment and the creation of a new state. Secession, the pet project of eastern slaveholders, would drag white westerners into a union with other slaveholders who likewise prized their chattel over white equality. White westerners would resist such action and break their political bondage by creating a new and free state. If Virginia "shows herself unfaithful, it will be at the expense of a division of the State," John G. Jacob declared. Northwesterners would "repudiate the hasty and fanatical Southern sentiment so prevalent East of the Blue Ridge." 174 If dismemberment occurred, "it was not the West, but the East, not the free labor, but the slave labor half" that deserved blame and

\footnotetext{
${ }^{171}$ Parkersburg News, December 20, 1860, 3. Emotions between secessionists and unionists in late 1860 were often tense. For example, Fabricius A. Cather attended a Union meeting in Taylor County only to have it "broken up by the disunionists." Diary entry, 26 November 1860, Fabricius A. Cather Civil War Diaries, A\&M 3633, WVRHC.

172 Parkersburg News, January 24, 1861, 2.

${ }^{173}$ Fairmont True Virginian, November 17, 1860, 2.

${ }^{174}$ Wellsburg Weekly Herald, January 11, 1861, 2.
} 
condemnation, he concluded. ${ }^{175}$ Republican Archibald W. Campbell concurred, declaring that "no affinity" had ever existed between eastern and western Virginians. Differences in "climate," "geography," and "slave populations" divided the Commonwealth. ${ }^{176}$ At a Union meeting in Wheeling's Fifth Ward, gatherers averred that should Eastern Virginians be "untrue to the Union and secede therefrom," these slaveholders "must go by themselves" as northwesterners "procure[d] the establishment of a separate, sovereign State." 177 Hancock County residents maintained that their "particular geographical position" made it "incumbent" upon them to adhere to the Union, even if it meant Virginia's division. ${ }^{178}$

Northwestern residents unaffiliated with the Republican Party downplayed the threat of dismemberment, considering it a last resort or ultimatum. Chester Hubbard believed that he and fellow northwesterners could "keep Virginia" under the Stars and Stripes, while exuding confidence that the "'handle' will stick to the 'pan." "179 A few weeks later, Hubbard judged that only the "smallest number" of residents "advocate a division of the state at present except under strong provocation from Eastern Va." Still, if Virginia only fought in "defence of her rights under the Constitution," he predicted that the state "will be a unit." ${ }^{180}$ Ritchie County residents considered the "division of the State by any line.... as worse than a dissolution of the National Union."181 Reflecting on the secession crisis, Waitman Willey considered a "division of the state" as the "'only alternative" available to residents if war commenced. ${ }^{182}$ Northwesterners,

\footnotetext{
${ }^{175}$ Wellsburg Weekly Herald, February 8, 1861, 2.

${ }^{176}$ Daily Intelligencer, December 25, 1860, 2.

177 Daily Intelligencer, January 21, 1861, 3.

${ }^{178}$ Daily Intelligencer, January 26, 1861, 4.

${ }^{179}$ Chester Hubbard to William Hubbard, 10 November 1860, Hubbard Family Papers, A\&M 805, WVRHC.

${ }^{180}$ Chester Hubbard to William Hubbard, 3 January 1861, Hubbard Family Papers, A\&M 805, WVRHC.

${ }^{181}$ Parkersburg News, January 24, 1861, 2.

182 Waitman Thomas Willey Diary, Volume 1, 92, A\&M 3, WVRHC.
} 
continuing a line of thinking present over the previous three decades, lamented a division of the state and would postpone such action until they exhausted all other options.

The formation of the Confederacy compelled the Virginia state legislature, under the instruction of Governor John Letcher, to convene an assembly of elected representatives to discuss this national crisis. Representatives elected by northwestern voters evinced slavery's continued importance in the region and in any decision residents would reach concerning secession. Preston County attorney William G. Brown, one of the largest slaveholders in the region, held seven slaves. ${ }^{183}$ Monongalia County attorney Waitman Willey and Ohio County Democratic congressman Sherrard Clemens both owned two slaves. ${ }^{184}$ Clemens' also possessed familial connections to the Deep South as his wife, Betty, hailed from Louisiana. ${ }^{185}$ Braxton County lawyer Benjamin Byrne and John Carlile of Harrison County were both slaveholders, too, owning three and one slaves respectively. ${ }^{186}$ While not a slaveholder, Benjamin Wilson, a lawyer representing Harrison County, used his legal training to protect slaveholders. Wilson acted as prosecuting attorney when Harrison County indicted three individuals, including Horace Greeley, for circulating the "incendiary" New York Tribune in the Northwest. ${ }^{187}$

Further south, in Kanawha County, George W. Summers held fourteen African American slaves while Spicer Patrick, a planter, owned twenty-two slaves. ${ }^{188}$ The election of these western representatives demonstrated that residents still sought to protect and champion slaveholders' privileges even though the majority of residents were nonslaveholders. These privileges were

\footnotetext{
1831860 U.S. Federal Census - Slave Schedules: Preston County, VA [Ancestry.com][accessed 28 May 2015].

${ }^{184} 1860$ U.S. Federal Census - Slave Schedules: Monongalia County, VA [Ancestry.com][accessed 28 May 2015] and 1860 U.S. Federal Census - Slave Schedules: Ohio County, VA [Ancestry.com][accessed 28 May 2015]. 1851860 U.S. Federal Census: Ohio, Virginia; Roll: M653_1368; Page: 450; Image: 462; Family History Library Film: 805368 [Ancestry.com][accessed 28 May 2015].

1861860 U.S. Federal Census - Slave Schedules: Braxton County, VA [Ancestry.com][accessed 28 May 2015] and 1860 U.S. Federal Census - Slave Schedules: Harrison County, VA [Ancestry.com][accessed 28 May 2015]. ${ }^{187}$ Hall, Rending of Virginia, 72.

1881860 U.S. Federal Census - Slave Schedules: Kanawha County, VA [Ancestry.com][accessed 28 May 2015].
} 
more secure in the Union than the Confederacy, residents argued, and demanded that their representatives pledged themselves as unconditional unionists. Chester Hubbard characterized the election for representatives as a "strong rebuke to Disunion in all shapes," believing residents had correctly manifested its fealty toward the Union. ${ }^{189}$ Residents concluded that this adherence to the Union could only be severed by popular referendum. ${ }^{190}$

While most northwesterners opposed secession, many believed that the convention offered an opportunity to redress some lingering constitutional grievances. Parkersburg newspaper editor Charles Rhoads hoped that the convention would apportion the state senate on the white basis, "equalize taxation" on all forms of property, and "abolish the County Court system." Rhoads, though, dismissed accusations that such demands represented an ultimatum where a failure to satisfy northwesterners would trigger dismemberment. ${ }^{191}$ One Preston County resident considered western Virginia the leading actor in the upcoming convention, as western delegates would "amend the Constitution" while eastern representatives "will have to take a 'back seat."' Any sectional drama would be driven by westerners, the author concluded. ${ }^{192}$ Clarksburg lawyer John Stringer Hoffman predicted that eastern delegates "will...yield uniform ad valorem taxation on all property," a grievance aired by many residents. ${ }^{193}$ The convention provided northwesterners an opportunity to reform the state constitution, not to precipitate a division of the state.

\footnotetext{
${ }^{189}$ Chester D. Hubbard to Waitman T. Willey, 4 February 1861, Charles H. Ambler Collection, A\&M 122, Box 10, Folder 6, item 292, WVRHC.

${ }^{190}$ William W. Freehling and Craig M. Simpson, Showdown in Virginia: The 1861 Convention and the Fate of the Union, (Charlottesville: University of Virginia Press, 2010), XI and Wellsburg Weekly Herald, February 15, $1861,2$. Freehling and Simpson argue that the majority in favor of a popular referendum west of the Blue Ridge was approximately 5-1.

${ }^{191}$ Parkersburg News, December 20, 1860, 2 and 1860 U.S. Federal Census: Parkersburg, Wood, Virginia; Roll: M653_1384; Page: 550; Image: 558; Family History Library Film: 805384 [Ancestry.com][accessed 28 May 2015$].$

${ }^{192}$ Kingwood Chronicle, February 2, 1861, 3.

193 John Stringer Hoffman to Caleb Boggess, 25 January 1861, Gideon D. Camden Collection, A\&M 1199, Box 6A, Folder November 1860 to February 1861, WVRHC.
} 
As northwestern representatives travelled to Richmond in early February 1861, the future appeared uncertain for northwestern residents and all Virginians. Would Virginia secede and join the Confederacy? If the state left the Union, how would northwestern residents respond? Was slavery's future more secure in the Confederacy? If the state remained in the Union, could slavery be maintained, even in the Northwest? Northwesterners' election of unconditional unionists reaffirms Daniel Crofts' argument concerning these "reluctant Confederates." Residents' economic interests and Whiggish political tendencies aligned them with similar northerners and westerners. Crofts, though, portrays Virginia's intrastate sectional conflict as inevitably concluding in dismemberment, an interpretation that marginalizes contingency and foreshadows West Virginia's creation. ${ }^{194}$ Few residents, except primarily Republicans, expressed a desire to pursue a division of the state. Most residents preferred remaining in the Old Dominion.

Residents' desire to remain in the Union and their marginalization of Republican ideology exhibited the political dynamics that had unfolded across the region over the previous years. Republicans had attempted to politicize what they interpreted as northwestern residents' ardent desire to defeat Virginia's "Slave Power" and free their region from political bondage. Demographic, economic, and geographical trends appeared favorable for a Republican Party to acquire a foothold in the Northwest. A burgeoning immigrant population, a declining slave and slaveholder population, commercial ties to northern and western markets, and an increasing wage labor population appeared to provide an opportunity to establish a Virginia Republican Party that could wield "free soil" and "free labor" politics in state affairs. Republicans' increasing national

\footnotetext{
${ }^{194}$ Crofts, Reluctant Confederates, 106-109. Crofts characterizes the sectional tensions that afflicted Virginia as "explosive," arguing that residents considered themselves "neglected and exploited by the rest of the state." Crofts centers this alienation on the lack of internal improvements, unfair taxation, and the failure of the 1851 Constitution to adjudicate the state's intrastate sectional conflict.
} 
popularity suggested that Virginia Republicans would receive patronage and assistance from a national party unafraid of "doughface" northerners. White northwesterners' political redemption was at hand.

Republicans, though, misjudged the popularity of their message and residents' antipathy toward slavery. The inauguration of universal suffrage in 1851 deepened residents' engagement in the "politics of slavery" and made them more acutely aware of threats to whiteness. Eastern Virginians' fears that universal suffrage would threaten slavery were unfounded; universal suffrage strengthened residents' commitment to slavery and slaveholders' interests. This commitment carried over into residents continued political affiliation, as Democrats and Oppositionists continued to dominate the political landscape. Though these parties differed in their approach to protecting slavery, patriarchy, and white supremacy, their positions gathered more support than Republicans. Northwestern residents were "reluctant Confederates" not only because of the economic and political tendencies Crofts identifies; their reluctance reflected their belief that their established and traditional hierarchies depended on slavery's survival. ${ }^{195}$ And nearly all residents maintained that slavery was safer in the Union and under the Constitution.

Northwesterners' belief that the Union protected slavery and slaveholders represented a fundamental disagreement with many eastern slaveholders. Tidewater and Piedmont residents elected the majority of representatives who favored immediate secession, arguing that a Republican administration would place slavery on a path toward extinction. Only a union with the Confederacy could protect African American bondage. ${ }^{196}$ Northwesterners' loathed Republicans, too, but maintained that Lincoln and his ilk would be constitutionally restrained

\footnotetext{
${ }^{195}$ Crofts, Reluctant Confederates, 159. Though Crofts argues that northwesterners defended slavery and believed that secession threatened it, he does not ground these beliefs in residents' maintenance of patriarchy and white supremacy.

${ }^{196}$ Link, Roots of Secession, 227.
} 
from interfering with slavery. Republicans could be defeated, northwesterners argued, by remaining in the Union, electing proslavery politicians, and fashioning new alliances with northern and western constituencies. Leaving the Union meant forgoing the checks and balances that constrained Lincoln and his Republican operatives, allowing them to inaugurate conflict on slavery. By early 1861 , most northwestern residents expressed a firm attachment to the Union not as a manifestation of their antislavery position but rather as an argument that their political independence depended on the maintenance of slavery under the Stars and Stripes. 
Chapter 6: Preserving the Union and Slavery: Secession and the Statehood Movement, 18611862

In early January 1862, the Clarksburg National Telegraph continued to warn northwesterners about the Confederacy. The "destruction" of the Confederate States of America "is foredoomed," the newspaper predicted, and pinpointed the "actions of the secession leaders" who "are afflicted with madness" as the cause for the southern confederacy's impending doom. This "madness" was manifest in Confederates' decision to secede and wage war against the United States. These men "profess to be fighting for their rights in slavery when they are doing the very thing that will injure the institution....[or] destroy it." African American bondage thrived under the Stars and Stripes because the federal government "has always...protect[ed] it," notably from hostile European nations who would now seek slavery's abolition. Slavery's future in the Confederacy appeared fleeting. ${ }^{1}$

For northwesterners, slavery's perpetuation ensured that racial hierarchy and patriarchy would continue to operate for the benefit of all white men, regardless of their slaveholding status. Northwesterners' political rights would remain sacrosanct, too. But the Confederacy's political principles threatened those hierarchies and those rights. The Confederate States sought to "immediately establish a strong Aristocracy or a Monarchy," the National Telegraph declared. This patrician ruling class would pronounce slavery as the Confederacy's "grand desideratum," restricting suffrage to slaveholders and using slavery as "the stepping-stone to both official and social position." Unlike northwesterners who claimed political independence without owning a slave, the status of a "free man" in the southern confederacy would only be achieved with the purchase of human chattel. $^{2}$

\footnotetext{
${ }^{1}$ National Telegraph [Clarksburg], January 3, 1862, 1.

${ }^{2}$ National Telegraph, January 3, 1862, 1.
} 
The National Telegraph revealed northwesterners' central objective as the Civil War entered its second year. The majority of residents demanded to remain in the Union, refusing to join the Confederacy at any cost. The newspaper's anti-Confederate stance reinforces prevailing historical scholarship that recognizes the Unionist grounds the Northwest occupied during the war. Unionists contended that the federal government provided slaveholders the greatest protection for their property, arguing that constitutional checks and balances, national political structures, and the armed forces all assisted slaveholders in maintaining power over slaves. Secessionists fundamentally disagreed and cited the growing Republican threat as evidence that slavery would soon be abolished. Though a minority, secessionists existed and operated throughout the region, often with impunity. Still, the majority of northwesterners' political compasses pointed to the Union.

The newspaper's commentary on slavery revealed the fruits of the 1851 Constitution. Politically and constitutionally empowered by that document, white, nonslaveholding northwesterners enjoyed tremendous political power. These men elected government officials from the governor to local judges, exercised suffrage without owning any property, and claimed the status of a "free man" without purchasing a slave. The Confederacy threatened those rights, as noted planters and patricians in that nation hoped to limit democracy and disenfranchise large numbers of Confederates. This project, begun before the war and with disciples in Virginia, too, revealed to white northwesterners the immense power they exercised and the fragility of that power. Slavery and democracy coexisted and strengthened each other, northwesterners declared, providing the proper political and constitutional foundation for their independence.

The National Telegraph published this commentary on slavery at an important time in the Northwest. Approximately two months prior, northwesterners had voted overwhelmingly to 
ratify a division ordinance that accelerated western Virginia's separation from the rest of the commonwealth. A constitutional convention in session at Wheeling now attempted to craft a state constitution that voters would ratify and Congress would approve. Two previous conventions also held in Wheeling, however, revealed diverse opinions concerning slavery's future in a new state. Few delegates or residents appeared willing to let slavery, reflecting the broad acceptance the institution enjoyed.

That northwesterners would still remained attached to the peculiar institution as late as 1862 challenges historians' arguments concerning northwesterners' interpretation of the secession crisis and the initial stages of the statehood movement. Contemporaries, including Union veteran Theodore Lang and Wheeling Daily Intelligencer report Granville Davisson Hall identified slavery as producing the "inequalities and injustice" that divided Virginians. This division became manifest in 1863, as the creation of West Virginia "brought the proud old State down from its ancient grandeur to its later humiliation." Westerners, unattached to slavery like their neighbors in Ohio and Pennsylvania, escaped this "humiliation." Charles Ambler provided a fitting coda to contemporaries' hagiographic interpretation of northwesterners' attitudes toward slavery during the secession crisis. "[L]ess than one year" after the 1860 presidential election, Ambler argues, "more than one-half" of voters in what would become West Virginia had become Republicans. A Republican electorate would assuredly not tolerate slavery or secession on behalf of slavery. ${ }^{4}$

\footnotetext{
${ }^{3}$ Hall, Rending of Virginia, 609 and Lang, West Virginia, 9, 137.

${ }^{4}$ Ambler, Sectionalism in Virginia, 333. George Ellis Moore offers a similar interpretation concerning northwesterners political affiliation and that influence on their Unionist position. The "true Unionists" hailed from the Northwest, Moore argued, as their "political beliefs" often "shaded into Republicanism." George Ellis Moore, $A$ Banner in the Hills: West Virginia's Statehood (New York: Appelton-Century-Crofts, 1963), 40.
} 
Modern historians have generally agreed that as the secession crisis intensified and war commenced, northwesterners desired slavery's abolition. Northwesterners operated in similar fashion to northerners, William Freehling argues, with most apathetic (if not supportive) of slavery but resistant to attempts by the "Slave Power" to enslave white men alongside black slaves. Northwesterners' concerns with equalizing taxes on slaves rather than attacking a Republican administration, though, further divided and alienated northwesterners from eastern Virginians. ${ }^{5}$ Daniel Crofts argues that the "shrill manifestations of western indignation about eastern dominance and mistreatment contained both an antislavery tone and a threat to divide the state." William Link agrees with Crofts' explicit connection between northwesterners' antislavery attitudes and the creation of a new state. "By 1860-61," Link argues, "many northwesterners" had developed a "new political consciousness" that "offered an aggressive critique of the politics of slavery." Dissatisfied with slaveholders' abuse of power over the past half-century, northwesterners drifted away from slavery and closer to their free state neighbors. ${ }^{7}$ The intrastate drama between eastern and western Virginians, Crofts and Link maintain, mirrored the national crisis and would reach a similar conclusion concerning slavery's future, as well. ${ }^{8}$

A fatal struggle between democratic reforms and slavery represents the central argument for these historians. Decades of national and state conflict centered on nonslaveholders resisting slaveholders' increasing dominion over political operations and structures, a characteristic that complemented Republicans' "Slave Power" thesis. The creation of a "modern proslavery and antidemocratic state" in 1860-61 represented the culmination of those political trends, Stephanie McCurry argues. This project defied western political traditions by restricting political

\footnotetext{
${ }^{5}$ Freehling, Road to Disunion: Secessionists Triumph, 526.

${ }^{6}$ Crofts, Reluctant Confederates, 159-160, 162.

${ }^{7}$ Link, Roots of Secession, 9.

${ }^{8}$ Link, "“This Bastard New Virginia,"” 38-40.
} 
representation and by creating a republic solely for white men. The "hubris" exhibited by white men who believed that slaveholding would trump democracy and restrict "the people" was "stunning," according to McCurry. The "reckoning" that unraveled the Confederate project represented a testament of the internal weakness and the "impoverished political vision" of Confederate leaders. ${ }^{9}$

McCurry's argument complements the body of historiography that posits increasing tension between democratic-minded northwesterners and eastern slaveholding oligarchs. Indeed, the statehood movement, a process decades in the making according to most historians, reflected a seemingly natural, if not inexorable, conclusion to Virginia's intrastate drama. For decades, eastern Virginians, under the pretext of protecting their chattel from western nonslaveholders, used constitutional, legal, and political powers to deny their transmontane brethren any measure of political equality. Eastern Virginians' decision to secede to protect their chattel over northwesterners' protestations destroyed any remaining ties residents held for slavery and Virginia. Northwest Virginians would no longer support slavery nor would they support Virginia. This interpretation has served as the dominant memory of the subsequent statehood movement, portraying the dismemberment of the state as a revolution against eastern Virginia slaveholders and slavery.

As revealed by the National Telegraph, this body of scholarship misinterprets how white northwesterners interpreted the dynamic between slavery and democracy during the secession crisis and early stages of the Civil War. Empowered by the 1851 Constitution, northwesterners wielded tremendous political and constitutional power and enjoyed rights practically on par with eastern slaveholding oligarchs. A few constitutional grievances remained, notably the tax

\footnotetext{
${ }^{9}$ McCurry, Confederate Reckoning, 1, 83.
} 
restrictions on African American slaves, but these were resolvable. Indeed, removing the tax restrictions placed on chattel would remove a festering inequality and grievance against slavery. Northwesterners declared that with Virginia in the Union and slavery secured, all white men regardless of their slaveholding status could rightfully claim the mantle of a "free man." Put simply, slavery had perfected the political power white men enjoyed. But Virginia's secession challenged that dynamic. White northwesterners believed that they had effectively checked Virginia planters' political hegemony over the past decade, but secession brought those planters together in a formal political alliance with likeminded Deep South planters and patricians. Much like these cotton aristocrats, Old Dominion planters had sought to stem and reverse the democratic tide that had washed away their aristocratic political structures and functions. The state's membership in the southern confederacy deepened that desire. Faced with the prospect of losing their hard fought political and constitutional rights, northwesterners began the process of creating a new state.

But historians err in interpreting this move toward creating a new state centered in the Northwest as an antislavery reaction. Over the preceding decades, northwesterners had deepened their fealty toward slavery and recognized the political independence they derived from the institution's presence. Abolishing the institution threatened to destabilize or destroy those rights and upset the established and traditional hierarchies that also buttressed African American bondage. Rather, Unionist northwesterners initiated a counterrevolution to protect slavery and democracy, maintaining that the perpetuation of each institution would ensure the survival and continuation of their political representation. ${ }^{10}$ This counterrevolution centered on resisting

\footnotetext{
${ }^{10}$ Manisha Sinha argues that South Carolinians, distrustful of democratic trends and consumed with consolidating their slaveholding power, instigated a "counterrevolution" to take their state out of the Union to protect African American bondage. I argue, though, that northwesterners initiated a similar "counterrevolution" to protect slavery
} 
secession through the ballot box and enlistment in the armed forces. These forms of resistance acted as a prelude to northwesterners' central objective of this counterrevolution, to create a new state where democracy and slavery would continue to exist in equilibrium. The statehood movement's initial stages reveal that though northwesterners understood the political obstacles incumbent in creating another slave state given the context, few relented. Slavery and democracy would continue to thrive in the hollows and hills of the Northwest.

On February 13, 1861, representatives from across the state gathered in Richmond to debate the state's future. Approximately one-sixth of these delegates championed immediate secession, with most representing counties with dense slave populations east of the Blue Ridge. Another one-sixth of delegates considered their fealty to the Union supreme to all other issues; most of these hailed from western Virginia and the Northwest in particular. The remaining twothirds were conditional unionists, representatives that sought to preserve Virginia's place in the Union but wary of Republican coercion. Most delegates waited to see how Lincoln and his administration would react to the secession crisis unfolding across the nation before deciding Virginia's future. Despite these differences, these delegates professed the same goal of protecting slavery. How to protect slavery, though, represented the fundamental difference that divided delegates. ${ }^{11}$

The beginning weeks of the convention contradict many historians' arguments concerning the Northwest's monolithic support for the Union. As Marion delegate and lawyer Ephraim B. Hall predicted, northwesterners "are going to have trouble here \& some of our

but this protection would occur within the Union. Manisha Sinha, The Counterrevolution of Slavery: Politics and Ideology in Antebellum South Carolina (Chapel Hill: University of North Carolina Press, 2000).

${ }^{11}$ Freehling and Simpson, Showdown in Virginia, X-XIV. 
western men will not pull true" to the Union. ${ }^{12}$ His prediction was accurate. If a conflict concerning residents' "allegiance" arose, Barbour County attorney Samuel Woods declared that his constituents would "yield obedience to the State of Virginia."13 Woods argued that "[m]idnight robbers and assassins" had violated northwesterners" "RIGHTS" and exhibited a "sentiment hostile to [Virginia's] institutions." "[I]nfuriated negroes, with pikes in their hands" aided these northern agents while northerners "canonized" radical abolitionists like John Brown as "saints and martyrs." John Brown's raid manifested the venom with which abolitionists had poisoned the northern body politic, turning northerners against southern institutions and society. Secession, Woods averred, would protect his constituents from northern voters who allegedly demanded racial equality at all costs. ${ }^{14}$

A meeting in Woods' district bolstered his secessionist stance. Barbour County residents "denounce[d] the doctrine of Federal coercion" and pledged their "obedience and allegiance to [Virginia] alone." The Old Dominion, along with other southern states, have "borne so patiently the encroachment of Northern fanaticism" until residents could no longer bear such injustices. The election of Abraham Lincoln now christened his party as the "dominant party" and would empower northern radicals to "perpetuate those grievances." Raids such as that perpetrated by John Brown would increase in frequency with an antislavery party in control of the White House. Faced with continued northern assaults on southern rights, these Barbour County residents prayed that Virginia would "immediately withdraw" from the Union. ${ }^{15}$

\footnotetext{
${ }^{12}$ Ephraim B. Hall to Francis H. Pierpont, 15 February 1861, Francis Harrison Pierpont Collection, A\&M 9, Box 2, Folder 22, WVRHC and 1860 U.S. Federal Census: District 4, Marion, Virginia; Roll: M653_1361; Page: 569; Image: 129; Family History Library Film: 805361 [Ancestry.com][accessed 15 June 2015].

${ }_{13}^{13}$ Proceedings of the Virginia State Convention of 1861, February 13-May 1, ed. George H. Reese (Richmond: Virginia State Library, 1965), 1:131 [hereafter cited as 1861 Proceedings] and 1860 U.S. Federal Census: Barbour, Virginia; Roll: M653_1334; Page: 212; Image: 218; Family History Library Film: 805334 [Ancestry.com][accessed 11 June 2015].

${ }^{14} 1861$ Proceedings, 2:586.

151861 Proceedings, 1: 632-633.
} 
Wetzel County lawyer Leonard S. Hall agreed with his Barbour County colleague. Hall believed that abolitionists' machinations would become more widespread with a Republican president. "The press, the pulpit, the school-house and the Sabbath school," Hall declared, "all exert their influence in hostility to the institutions of the South." These institutions could broadcast their hatred of slavery and southern society with Lincoln granting impunity to such messages. ${ }^{16}$ Further, Wetzel's proximity on the Ohio River made it an attractive "terminus" for the "underground railroad," forcing residents to abandon slavery lest "emissaries" abscond with their human chattel across the river. But the presence of only a few slaves and slaveholders should not cloud other Virginians' interpretation of Wetzel's citizens. "[N]o sounder State-rights people" existed in the state than Hall's constituents, and these residents believed that northerners' increasing hostility toward slavery forecasted future conflicts concerning the institution. Only an alliance with the Confederacy could secure slavery and stymie the work of “emissaries" lurking along Wetzel's borders. ${ }^{17}$

Though most northwestern delegates opposed Woods' and Hall's secessionism, all agreed that slavery and slaveholders' rights demanded protection. They believed that disrupting the master-slave relation threatened all northwesterners, whether or not they owned slaves. ${ }^{18}$ Harrison County lawyer Benjamin Wilson worried that abolition would unleash a "half-caste race" that lacked the "capacity for self-government." Soon, the "time of our courts would be occupied in trying them for crime" while the state would be "heavily taxed to defray their criminal expenses.” Perpetuating slavery ensured that African Americans remained in their

\footnotetext{
161861 Proceedings, 2:398 and 1850 U.S. Federal Census: District 64, Wetzel, Virginia; Roll: M432_981; Page: 41A; Image: 87 [Ancestry.com][accessed 11 June 2015].

171861 Proceedings, 1:133.

${ }^{18}$ Northwestern Republican organs generally denounced this fealty. John G. Jacob, editor of the Wellsburg Weekly Herald, groaned that he was "sick of this eternal pulling about 'loyalty to Virginia." Wellsburg Weekly Herald, March 1, 1861, 2.
} 
proper place. ${ }^{19}$ Sherrard Clemens, representing Ohio County and an owner of two slaves, rejected claims that he "stood upon a platform which was advocated by the editor of the Wheeling 'Intelligencer.'” That Republican organ, Clemens argued, evinced its hostility to slaveholders and the institution through its free labor and free soil diatribes. ${ }^{20}$ Harrison County attorney John S. Carlile, a slaveholder, emerged during the convention as one of slavery's most vocal advocates. Carlile considered the institution a "social, political, and religious blessing," and declared himself a "slaveholder, not by inheritance, but by purchase." His declaration of purchasing rather than inheriting slaves functioned as a powerful shibboleth in late antebellum Virginia. Carlile manifested his approbation of the institution and proslavery credentials through deliberate choice, not empty rhetoric. This financial stake in African American bondage proved useful in bolstering his support for tax reform and remaining in the Union. Such steps, he avowed, would protect his investment along with thousands of other Virginians. His election to this convention testified to his constituents' approval of his status as a slaveholder and his proslavery ideas, as well. ${ }^{21}$

Many northwestern delegates stressed their constituents' fealty toward slavery, reminding colleagues of northwesterners' unwavering support for the institution. Carlile averred that though few northwesterners held a "pecuniary interest" in African American bondage, all residents championed the axiom that " African slavery... is essential to American liberty.",22

\footnotetext{
${ }^{19} 1861$ Proceedings, 2:360 and 1860 U.S. Federal Census: Clarksburg, Harrison, Virginia; Roll: M653_1351; Page: 757; Image: 247; Family History Library Film: 805351 [Ancestry.com][accessed 11 June 2015].

${ }^{20} 1861$ Proceedings, 1:143; 1860 U.S. Federal Census: Ohio, Virginia; Roll: M653_1368; Page: 450; Image: 462; Family History Library Film: 805368; and 1860 U.S. Federal Census - Slave Schedules: Ohio County, VA [Ancestry.com][accessed 11 June 2015].

${ }^{21} 1861$ Proceedings, 1, 468; 1860 U.S. Federal Census: Clarksburg, Harrison, Virginia; Roll: M653_1351; Page: 754; Image: 244; Family History Library Film: 805351; 1860 U.S. Federal Census - Slave Schedules: Harrison County, VA [Ancestry.com][accessed 11 June 2015].

${ }^{22} 1861$ Proceedings, 1: 457-458. The Republican Wheeling Daily Intelligencer, though it disagreed with Carlile's proslavery stance, applauded him for being "sound on the great issue of Secession or Union, law or anarchy." He
} 
Doddridge County lawyer Chapman J. Stuart proclaimed that his constituents have been "loyal and true to the institutions of their State...especially to the institution of slavery."

Northwesterners had "stood up for the institution and the rights of slavery" and Virginia slaveholders would continue to "find us at our posts ready to do battle for it.". as sound and as emphatically Southern as the people of Richmond," Marion County lawyer Alpheus Haymond explained. "[N]o want of loyalty to any of the institutions of Virginia" existed among his neighbors. ${ }^{24}$

As during the Reform Convention a decade earlier, Monongalia County lawyer and slaveholder Waitman T. Willey emerged as the Northwest's principal spokesman. He dismissed eastern Virginians accusations concerning the Northwest's unsoundness on the issue of slavery, reminding delegates that more passionate supporters of the institution could not be found outside of the Northwest. A "very serious misapprehension" and "intimations and insinuations prejudicial to the character" of his district had "been busily circulated" but such claims were unfounded, Willey declared. Monongalia County residents were ready to "defend [Virginia's] rights to the death," a "universal" sentiment in the trans-Allegheny. Unconvinced delegates needed only to reflect upon his constituents' history in defending and supporting Virginia slaveholders.

In what portion of our history can a single incident be pointed to that would subject us to the ban of your distrust? In what have we been derelict? In what have we been faithless? When did we not come up to the full demands of justice to the East on all questions? Never. ${ }^{25}$

\footnotetext{
"has done his duty as a Western man, as a Virginian, [and] as an American citizen." Daily Intelligencer, March 11, $1861,2$.

${ }^{23} 1861$ Proceedings, 3:51 and 1860 U.S. Federal Census: Doddridge, Virginia; Roll: M653_1342; Page: 482; Image: 490; Family History Library Film: 805342 [Ancestry.com][accessed 11 June 2015].

${ }^{24} 1861$ Proceedings, 2: 61 and 1860 U.S. Federal Census: District 4, Marion, Virginia; Roll: M653_1361; Page: 572; Image: 132; Family History Library Film: 805361 [Ancestry.com][accessed 11 June 2015].

${ }^{25} 1861$ Proceedings, 1: 136-137; 1860 U.S. Federal Census: District 2, Monongalia, Virginia; Roll: M653_1364; Page: 74; Image: 84; Family History Library Film: 805364; and 1860 U.S. Federal Census - Slave Schedules: Monongalia, VA [Ancestry.com][accessed 11 June 2015].
} 
Eastern delegates' baseless accusations represented the true danger to slavery, Willey asserted, not his northwestern neighbors. Their continued attacks on northwesterners' proslavery credentials threatened to turn residents against the institution. Such a turn of events would prove disastrous for slaveholders. For if a national conflict arose concerning the institution, where would eastern Virginians "get the strong arms to defend your slaves?" "From our glorious mountains of the West," he answered. Eastern Virginians needed northwesterners' support. ${ }^{26}$ Northwesterners' continued support for eastern Virginians' chattel could be secured through two important measures. The first was to remain in the Union. Though secessionists claimed that remaining in the Union would prove the death knell of slavery, northwestern unionists maintained that the federal government strengthened and protected the institution. Delegates needed to look no further than to John Brown's failed raid in 1859. Carlile reminded delegates that when the abolitionist attempted to incite a slave rebellion, "fourteen... marines belonging to the Federal Government" captured Brown and delivered him to Virginia authorities. He doubted that a Confederate army stationed in Richmond could mobilize with greater speed in future crises. ${ }^{27}$

The federal government's response to Harpers Ferry demonstrated to Carlile the Union's continued defense of slaveholders' rights. Under "our common Constitution," the "army," "navy," and the "gallant voters of the non-slaveholding states" will "battle in defence of our rights." ${ }^{28}$ Willey agreed, reminding delegates that the "Supreme Judicial tribunal" had "guarantee[d]" the "right of every slaveholder...to carry his property into all the territories." 29

\footnotetext{
${ }^{26} 1861$ Proceedings, 3: 5.

27 1861 Proceedings, 1: 477.

${ }^{28} 1861$ Proceedings, 1: 458.

${ }^{29} 1861$ Proceedings, 1: 361. Willey referenced the 1857 Dred Scott decision, where the U.S. Supreme Court argued that slaveholders could take their property into the territories.
} 
This federal assistance would continue unabated even with a Republican in the White House.

The "Black Republican" Party only controlled the "powerless" executive branch and "can do no harm" to slavery unless Virginians secede, Carlile stressed. ${ }^{30}$ But if eastern Virginians dragged the state out of the Union, he predicted that slavery would "not exist in Virginia five years after the separation." The "whole civilized world" demanded slavery's "ultimate extinction," he claimed. Only the U.S. government, not the impotent Confederacy, could guarantee slavery's existence. $^{31}$

Willey echoed Carlile's fatalistic prediction concerning slavery in the Confederacy. Virginia's secession would "bring Canada to our doors," increasing slaves' "motive to escape." Northwestern slaveholders, fearful of losing their property, would "themselves remove farther South, or...sell their slaves to be sent farther South." Slavery's erosion along the South's periphery would produce tremendous harm. The region's political clout would decrease, empowering Republicans to reach deeper and more aggressively into the South. Southerners would be "hemmed in by a cordon of hostile elements," he concluded. ${ }^{32}$ The boundaries between Virginia and its northern neighbors would become a conflict zone, threatening to "make North-Western Virginia the Flanders of America." Confederate soldiers would be unable to rescue northwesterners, as Virginia legislators had failed to provide sufficient "legislative aid to

\footnotetext{
${ }^{30} 1861$ Proceedings, 2: 315. Willey also emphasized the constraints that Lincoln faced even as he assumed control of the executive branch. Before the secession of other southern states, Lincoln "could not have appointed an officer in the whole federal government... without the consent and ratification of the South." Further, "we never would have had a law objectionable to the South presented to him to be signed, and made final according to the provisions of the Constitution." The minority status southerners enjoyed, he declared, occurred because seven southern states had left the Union and leaving behind eight slaveholding states. Reese, Proceedings, 1: 363.

${ }^{31} 1861$ Proceedings, 1: 469.

321861 Proceedings, 1: 367. Willey recognized a high level of agency in slaves if disunion occurred. He asserts that the "slave will soon be apprized" of such a development. The slave "will know that when he reaches this line [Virginia's border with Ohio or Pennsylvania] he will be safe; and escape he will."
} 
transpierce these mountains" that divided the state. This apocalypse could only be prevented by remaining in the Union. ${ }^{33}$

Remaining in the Union provided security and safety for northwestern slaveholders and their chattel. The Union also protected northwesterners from the antidemocratic mindset that Deep South planters and patricians had exhibited over the years. This mindset, residents observed, had deepened with the creation of the southern confederacy. In a meeting held prior to the convention, Morgantown residents declared their opposition to being placed under the "rule of King Cotton." 34 The epithet of "King Cotton" meant more than the overwhelming economic importance placed on cotton production while other agricultural and commercial interests suffered; rather, "King Cotton" symbolized the political tyranny exhibited by Deep South slaveholders. These cotton planters considered the Confederacy's establishment as a "moment of possibility" to purge "corrupting democratic tendencies" that had infected southern states. Chief among these "tendencies" were universal male suffrage, frequent elections, and unmooring property from politics. Deep South elites believed these democratic reforms compromised slavery and threatened to inaugurate "Yankee" politics on southern soil. ${ }^{35}$

This phenomenon unfolded in Virginia after the ratification of the 1851 Constitution. That democratic document empowered nonslaveholders across the state through universal suffrage, direct election of government officials, and greater representation in the state legislature. The result was a more transparent and open political system that checked planters' political hegemony. But foes of Virginia's democratic transformation existed. One Virginian decried the reign of "King Numbers," fearing the "deep and radical changes" that this ruler

\footnotetext{
331861 Proceedings, 1: 370.

${ }^{34}$ Daily Intelligencer [Wheeling], February 7, 1861, 2.

${ }^{35}$ Michael T. Bernath, "The Confederacy as a Moment of Possibility,” Journal of Southern History, 79, no. 2 (May 2013): 325-335.
} 
would inaugurate. "[C]herished and venerated institutions" would be destroyed and "long established opinions and principles" would be overturned. ${ }^{36}$ John Coles Rutherfoord, a lawyer, slaveholder, and member of the House of Delegates, expressed similar fears. "[P]ublic opinion... is king," he lamented, "making and unmaking the laws or setting them at naught...and sweeping away whatever it opposes." 37 Southerners needed to "modify" their political institutions, proslavery theorist George Fitzhugh asserted, to dethrone "King Numbers." Modifications included "remov[ing] the people farther from the direct exercise of power," "lengthen[ing] the tenure of office," and shielding representatives from public opinion. $\mathrm{He}$ applauded South Carolina for already implementing such measures. "Aristocracy is the only safeguard of liberty," he concluded, and stressed that unless planters restricted political representation, the South, much like the North, would soon devolve into "pure democracy" and "anarchy." 38

Northwesterners' feared that Virginia's membership in the Confederacy could assist these antidemocratic foes in manifesting their desires. The "political views of the South Carolina school of politicians," Wellsburg residents declared, rejected majoritarian rule and restricted political participation to only slaveholders. How could northwesterners' democratic rights be protected in a union with such politicians $?^{39}$ The Wheeling Daily Intelligencer reported that a recent issue of the Richmond-based Southern Literary Messenger contained articles that denounced "universal suffrage of the white man" as a "disgraceful failure." "African slavery"

\footnotetext{
36 "The Constitution of Virginia, 1851," Southern Literary Messenger, 12 no. 2 (October 1855): 363-384.

${ }^{37}$ John Coles Rutherfoord, Speech of John C. Rutherfoord, of Goochland, in the House of Delegates of Virginia, 21 February, 1860, in favor of the proposed Conference of Southern States (Richmond: William H. Clemmitt, 1860), 11; 1860 U.S. Federal Census: Goochland, Virginia; Roll: M653_1347; Page: 859; Image: 519; Family History Library Film: 805347 [Ancestry.com][accessed 16 June 2015]; and, 1860 U.S. Federal Census - Slave Schedules: Goochland County, VA [Ancestry.com[accessed 16 June 2015].

38 "The Message, the Constitution, and the Times." De Bow's Review, 30 (February 1861): 163-164.

${ }^{39}$ Wellsburg Weekly Herald, January 11, 1861, 2.
} 
would provide the foundation for the southern confederacy, thereby consolidating political power in the "fewest possible numbers" and forcing the "poor white man to emigrate." 40 The "ballotbox," that "mighty engine for the redress of grievances," would be inaccessible to white men unless they owned African American slaves. "[A]ristocrats say they will do...[the] thinking...legislating and governing" for all white men. ${ }^{41}$

The abrogation of northwesterners' democratic rights in the Confederacy constituted a central argument during the convention. "South Carolina initiated this movement," John Carlile reminded delegates, and that state "will control this movement." The Palmetto State's propertyholding requirements for political office would be replicated in the Confederate national government, too, forcing nonslaveholders into a state of political bondage. ${ }^{42}$ Confederates had already constructed a government lacking "popular sanction,” Willey observed, as Jefferson Davis had been appointed, not popularly elected. He predicted that the southern confederacy would soon be ruled by an "oligarchy, or constitutional monarchy, or military despotism." 43 And with cotton planters controlling the government and reluctant to relinquish that power, the future appeared bleak for white nonslaveholders in the Confederate States. "It seems to me this Southern Confederacy," Willey warned, "is disposed to repudiate the principle that the political power resides in the people."44 In Morgantown, merchant Henry Dering supported his delegate's conclusions. Monongalia County residents "will not be put along with the Cotton States," he declared, and "pray[ed]" that Willey and other northwestern delegates would "keep Va. in her

\footnotetext{
${ }^{40}$ Daily Intelligencer, January 29, 1861, 2.

${ }^{41}$ Daily Intelligencer, February 28, 1861, 2.

421861 Proceedings, 1: 468.

43 1861 Proceedings, 1: 369.

44 1861 Proceedings, 1: 369.
} 
present position." 45 Northwesterners opposed any measure that would "precipitate the old Dominion out of this glorious Union, [and] into the treasonable bosom of King Cotton."46 Membership in the Confederate States endangered slavery and democracy, the two wellsprings of northwesterners' political rights. Remaining in the Union, though, would ensure their perpetuity.

Remaining in the Union represented northwestern delegates' primary objective in the convention and would deepen northwesterners' desire to protect eastern Virginians' chattel. Reforming the tax code, specifically by equalizing taxation across all property, constituted the second measure northwestern delegates believed would further solidify their constituents' fealty toward easterners' property. ${ }^{47}$ These exemptions, enacted by the 1851 Constitution, generated sectional and class friction while providing fodder for Republicans who believed that the exemptions reflected the machinations of the "Slave Power." Resolving this taxation issue, northwesterners assured the convention, would not destroy the institution. Rather, eliminating these restrictions would ease sectional and class tension and strengthen residents' support for slavery. As Alpheus Haymond explained, equalizing taxation would "harmonize this Commonwealth from one end to the other" and make Virginians "one and indivisible in

\footnotetext{
${ }^{45}$ Henry Dering to Waitman T. Willey, 23 February 1861, Charles H. Ambler Collection, A\&M 122, Box 10, Folder 6, item 295, WVRHC and 1860 U.S. Federal Census: Morgantown, Monongalia, Virginia; Roll: M653_1364; Page: 11; Image: 17; Family History Library Film: 805364 [Ancestry.com][accessed 16 June 2015].

${ }^{46}$ Henry Dering to Waitman T. Willey, 19 March 1861, Charles H. Ambler Collection, A\&M 122, Box 10, Folder 6, item 303, WVRHC.

${ }^{47}$ Many northwestern delegates argued that the convention provided the opportunity to resolve constitutional issues that continued to plague their constituents. Alpheus Haymond's motion for a "general examination of our state constitution" would explore "all the subjects of state policy- taxation, white basis in both houses, county courts, election of the judiciary, \&c. \&c. will come up for consideration." But most northwesterners focused on taxation as the principle issue that affected them. As Chester's brother, Jack Hubbard, explained, northwesterners "want the white basis and advalorem tax pushed hard - such sentiment is not confined to the Republican party" and approximately " $3 / 4$ of the people from the mouth of the Big Kanawha through to the Alleghenies" desired these two reforms. Chester Hubbard to William Hubbard, 25 February 1861, Hubbard Family Papers, A\&M 805, WVRHC and Jack Hubbard to Chester Hubbard, 4 March 1861, Hubbard Family Papers, A\&M 805, WVRHC.
} 
sentiment and feeling." An ad valorem tax on slaves would not endanger the institution; it would strengthen it. $^{48}$

The debate concerning taxation commenced on March 7 when Preston County attorney William Guy Brown moved that the convention establish a committee to explore ad valorem taxation on all forms of private property. Brown's initial argument in offering this motion centered on the need to equip, arm, and feed an army should military conflict break out. Brown observed that "Eastern citizens are prepared now...to subject their property to equal taxation...[to] help us now raise the sinews of war."49 The convention tabled Brown's motion 69-41, but Willey introduced a similar measure nine days later, garnering the approval of northwestern secessionists and unionists. ${ }^{50}$ Secessionist Samuel Woods of Barbour County observed that the "common masses of the people... are at a loss to understand" why the state fully taxed land yet exempted African Americans under the age of twelve. ${ }^{51}$ Ephraim B. Hall bemoaned the "odious distinction" and "inequality" created by these restrictions, and believed that this "inequality" should be resolved before delegates settled Virginia's future. ${ }^{52}$ Benjamin Wilson predicted that a "dire and awful conflict" between the "laboring man and the slave owner" would unfold in the Old Dominion unless delegates resolved this issue. Wilson reminded delegates that "[m]ore true and more loyal friends of the negro interest are no where to be found than in the Western party of the state." Providing justice to northwesterners would ultimately strengthen the bonds between them and slaveholders, an important task given the

\footnotetext{
481861 Proceedings, 2: 61.

491861 Proceedings, 1: 443-444.

${ }^{50}$ Freehling and Simpson, Showdown in Virginia, 136.

511861 Proceedings, 2: 51.

521861 Proceedings, 2: 341-342.
} 
national political climate. Refusing to yield on this issue, however, threatened to attenuate those bonds. $^{53}$

William Brown expounded on his earlier support for the ad valorem tax on slaves. As an owner of seven slaves, he was "interested directly in the institution of slavery" and its preservation. Brown expressed similar paternalistic attitudes as other Virginians, professing that the institution was "ordained of God himself for the purpose of redeeming the African race from barbarism." The Northwest's scarce slave population, though, should not persuade fellow Virginians that his neighbors believed differently. Though northwesterners "may not have as much of that peculiar kind of property as" eastern Virginians, slavery "will never be injured or disturbed" by the "people of North-western Virginia." By removing the tax restrictions on slaves, delegates would ensure that all citizens "bear [the] equal proportion of the burdens of Government." This equality would deepen his constituents' paternalistic and proslavery sentiments. $^{54}$

Willey, a slaveholder like Brown, provided a full defense for removing the tax restrictions on black slaves. The "laggard" construction of western internal improvements was a visual representation of this policy's operation. Lacking sufficient roads, canals, or railroads to eastern markets, northwesterners used natural channels to transport goods to northern and western markets. This flow of commerce to external markets consolidated capital in northern states while "Northern population," "power," and "the ratio of representation against us" increased. Republicans, now the dominant party in the North, benefited from this arrangement. ${ }^{55}$ The operation of this tax policy among nonslaveholders was equally appalling. Willey confessed

\footnotetext{
${ }^{53} 1861$ Proceedings, 2: 16.

${ }^{54} 1861$ Proceedings, 2: 6-8.

${ }^{55} 1861$ Proceedings, 3: 6.
} 
that he felt a "sense of mortification" knowing that the state taxed "every cent" that belonged to his "non-slaveholding neighbor" while his property was "exempt from taxation."56 Though northwesterners had spearheaded this movement to equalize taxation, he denied any sectional prejudice. Taxation "is not a sectional question," he declared, but a "question between the nonslaveholding and the slaveholding portions of the people of Virginia." White laborers in Richmond, Petersburg, and Lynchburg along with white farmers in the countryside paid a full share of taxes while a slaveholders' chattel labored and masters paid only a fraction of taxes. This scenario represented the true threat to slavery, Willey inferred, not that slaveholders paid more taxes. ${ }^{57}$

Despite their efforts to show the injustices created by the tax restrictions, northwestern delegates failed to persuade Piedmont and Tidewater delegates. These eastern delegates maintained that the convention should settle federal matters before addressing issues such as taxes or representation in the state legislature. Petersburg merchant and slaveholder Thomas Branch declared that he would consider a "re-organization of the organic law" on taxation after the "Convention shall have determined that the State shall leave the Union." 58 "That is the way the whip is cracked over the head of Western men," complained the Wheeling Daily Intelligencer ${ }^{59}$ Ephraim Hall stated that secessionists' suggestion to "buy us" while offering "all we asked on the question of negro tax" received quiet endorsement from some colleagues. ${ }^{60}$ Lewis County attorney Caleb Boggess confirmed such divisions, admitting that "a great number

\footnotetext{
561861 Proceedings, 1: 767.

57 1861 Proceedings, 2: 507-508.

581861 Proceedings, 2: 17; 1860 U.S. Federal Census: Petersburg South Ward, Petersburg (Independent City), Virginia; Roll: M653_1342; Page: 326; Image: 332; Family History Library Film: 805342 [Ancestry.com][accessed 16 June 2015]; and, 1860 U.S. Federal Census - Slave Schedules: Petersburg, VA [Ancestry.com][accessed 16 June $2015]$.

59 Daily Intelligencer, March 29, 1861, 2.

${ }^{60}$ Ephraim B. Hall to Francis H. Pierpont, 18 March 1861, Francis Harrison Pierpont Collection, A\&M 9, Box 2, Folder 22, WVRHC.
} 
of the Valley members and some of the Western Members... are opposed" to removing tax restrictions on slaves. Plagued by divisions, northwesterners attempts to reform the tax code had stalled by early April. ${ }^{61}$ By mid-April, though, northwesterners' prospects improved as the convention approved Willey's motion to form a committee to explore removing the tax restrictions on slaves. ${ }^{62}$

Even with this important victory, the convention's laggard pace coupled with secessionists' obduracy frustrated northwestern residents and delegates. This frustration persuaded some northwesterners that dismemberment should remain on the table. Barbour County delegate Samuel Woods lamented a "rupture of the good old Commonwealth of Virginia" but maintained that representatives in Richmond needed to provide "equal justice to every section" of the state to prevent such a calamity from unfolding. ${ }^{63}$ In Morgantown, Henry Dering demanded "our just rights" and "equality in our own state, or in lieu of it, a division of the state." "give us our rights - make us freeman and equals by the law with themselves," northwesterners "will be the last to ask for a division of the state." "[G]ive us what rightfully belongs to us," the newspaper concluded, “and we will never say division, Never, Never, Never." Refusing to provide northwesterners justice, though, would intensify the demands for dismemberment. ${ }^{65}$

By early April, events within and without the convention provided mixed signals concerning Virginia's future. On April 4, delegates voted 90-45 against immediate secession. ${ }^{66}$

\footnotetext{
${ }^{61}$ Caleb Boggess to Unidentified, 5 March 1861, Gideon D. Camden Collection, A\&M 1199, Box 6A, Folder March 1861 to May 1862, WVRHC and 1860 U.S. Federal Census: Weston, Lewis, Virginia; Roll: M653_1358; Page: 186; Image: 194; Family History Library Film: 805358 [Ancestry.com][accessed 16 June 2015].

${ }^{62}$ Freehling and Simpson, Showdown in Virginia, 152.

${ }^{63} 1861$ Proceedings, 2: 55.

${ }^{64}$ Henry Dering to Waitman T. Willey, 26 March 1861, Charles H. Ambler Collection, A\&M 122, Box 10, Folder 6, item 306, WVRHC.

${ }^{65}$ Virginia Plain Dealer [Middlebourne], April 5, 1861, 2.

${ }^{66}$ Tarter, Grandees of Government, 209.
} 
In Washington, D.C., Augusta County delegate John B. Baldwin met secretly with President Lincoln to ascertain his intentions concerning Fort Sumter in Charleston harbor and the unfolding national crisis. ${ }^{67}$ While the vote rejecting secession encouraged northwestern delegates, Baldwin's visit proved disappointing, as Lincoln had allegedly supported resupplying troops in Fort Sumter with food and other essentials without first consulting Virginia unionists. ${ }^{68}$ Other delegates, unaware of this visit, agreed to send three representatives on a similar factfinding mission Baldwin undertook a few days earlier. During their meeting on April 13, Lincoln informed the three delegates that the "unprovoked assault" on Fort Sumter the previous day would compel the president to "repossess" any and all federal forts lost to the Confederacy. ${ }^{69}$

The firing on Fort Sumter, though, failed to turn unionists into secessionists or convince delegates that war was inevitable. Delegates offered a variety of explanations for the assault on the federal installation. Some accused South Carolina for instigating the conflict while others were confident that the conflict would be localized to Charleston harbor. Some unionist delegates believed that their compromise measures would be considered more seriously by all parties now that fiery rhetoric had turned into open hostilities. Immediate secessionists like former governor Henry A. Wise were apoplectic that Virginians dithered while war was afoot. ${ }^{70}$ But on April 15, President Lincoln's request for 75,000 troops, including 2,340 officers and men from the Old Dominion, changed the convention's atmosphere and numerous delegates' stance

\footnotetext{
${ }^{67}$ Freehling and Simpson, Showdown in Virginia, 153-154.

${ }^{68}$ John B. Baldwin, Interview between President Lincoln and Col. John B. Baldwin, April 4, 1861: Statements and Evidence (Staunton, VA: Spectator Office, 1866), 11-13. While the veracity of Baldwin's testimony-given five years after the interview with Lincoln — is questionable, it nonetheless indicates a sense of misunderstanding between Lincoln and Virginia unionists.

${ }^{69}$ Freehling and Simpson, Showdown in Virginia, 155-160; 1860 U.S. Federal Census: Montgomery, Virginia; Roll: M653_1363; Page: 704; Image: 202; Family History Library Film: 805363 [Ancestry.com][accessed 23 June 2015]; and, 1860 U.S. Federal Census - Slave Schedules: Montgomery, Virginia [Ancestry.com][accessed 23 June 2015]. The three delegates sent to Lincoln were Preston, Alexander H.H. Stuart of Augusta County, and George Wythe Randolph of Richmond.

${ }^{70}$ Freehling and Simpson, Showdown in Virginia, 160-161.
} 
on secession. ${ }^{71}$ Delegates convened in secret session, with Wise and George Wythe Randolph of Richmond declaring that the welfare of the republic required an immediate military response to Lincoln's "coercive" declaration before public ratification of a secession ordinance. ${ }^{72}$

Wise's assertion that military mobilization against the Union must occur prior to popular approval or rejection of secession infuriated northwestern unionists. Sherrard Clemens of Ohio County declared that delegates "must await the decision of the people upon" the secession ordinance before Virginians seized military installations or aligned with the Confederacy. ${ }^{73}$ Wood County lawyer John J. Jackson was "astounded" that secessionists planned to capture "public property within the limits of Virginia" before Virginians offered their blessing to such actions. Indeed, Jackson considered Wise's suggestion a "sham" and a "solemn farce" that would place Virginians in a "peculiar embarrassment." Virginians would be in political limbo as the state collaborated with the Confederacy but remained in the Union until the public approved of secession. ${ }^{74}$ Secessionists' desire to withdraw the state without the consent of the body politic would prove the death knell of slavery, Willey predicted. "We are certainly not yet out of the Union," he declared, warning that this "hasty measure" will "destroy the loyalty of the best friends that ever your slaveholders had." Secessionists' headlong rush to sever Virginia's ties to the nation "will dissolve the state," placing easterners' property in a precarious situation. ${ }^{75}$

\footnotetext{
71 Tarter, Grandees of Government, 210. News of Lincoln's call for troops frustrated some northwestern residents. Gideon Camden lamented the "intended course of the administration," considering it "cowardly" and misleading. Though the Lincoln administration advertised its policy as "peaceful," it was "preparing for coercion." Still, Camden "hope[d] that some prompt \& firm action on the part of the border slave states will avert a civil war." Gideon Camden to [?], 16 April 1861, Gideon D. Camden Collection, A\&M 1199, Box 6A, Folder March 1861 to May 1862, WVRHC.

721861 Proceedings, 3: 757-759 and 1861 Proceedings, 4: 4-9.

731861 Proceedings, 4: 109.

741861 Proceedings, 4: 32-33 and 1860 U.S. Federal Census: Parkersburg, Wood, Virginia; Roll: M653_1384; Page: 549; Image: 557; Family History Library Film: 805384 [Ancestry.com][accessed 29 June 2015].

751861 Proceedings, 4: 51-52.
} 
Such pleas, however, failed to stop the convention's march toward secession. Delegates approved the ordinance, 88-55, with a popular vote on the ordinance to occur on May 23. A handful of northwestern delegates voted in favor of the ordinance, while one abstained and the majority voted against its ratification. ${ }^{76}$ Though the public would vote on the ordinance in approximately one month, the scenes around Richmond convinced one northwestern delegate that Virginia's fate was with the Confederacy. Benjamin Wilson marveled at the "excitement and action of the people" outside the convention. "Companies are leaving every day," he observed, while residents exhibited a "furnished determination to seize all public property within the state" and "almost every man \& boy... has a gun and sword in hand." saw no point in waiting for public ratification of the ordinance; Virginia was no longer in the Union. $^{78}$

Unionist northwesterners felt despondent about the convention's action but determined to continue their fight for slavery, democracy, and the Union. John S. Burdett of Taylor County left Richmond on April 17 to inform his constituents of the convention's decision; a few days later, John Carlile and most other northwestern delegates had left the convention and arrived in the Northwest by April 21. Carlile convened a meeting in Clarksburg on April 22 and over onethousand residents answered the call to attend this unionist rally. These northwestern unionists decried secessionists' actions in seizing federal installations and custom houses in the state capital without sanction from voters. The "people of Virginia...by their votes, and through the

\footnotetext{
${ }^{76}$ Northwestern delegates who voted in favor of the ordinance included Cyrus Hall of Pleasants and Ritchie; Leonard S. Hall of Wetzel; John N. Hughes of Randolph and Tucker; and Samuel Woods of Barbour. Benjamin Wilson of Harrison abstained from voting on the ordinance. Alpheus Haymond and George Berlin, who initially voted against the ordinance, changed their votes in favor on April 23. A State of Convenience: The Creation of West Virginia, "Voting Results on the Virginia Ordinance of Secession," West Virginia Archives \& History [http://www.wvculture.org/history/statehood/rcdelegates.html] [accessed 24 June 2015].

${ }^{77}$ Benjamin Wilson to unidentified, 19 April 1861, Benjamin Wilson Letter Regarding Conditions in Richmond after Passage of Ordinance of Secession, A\&M 3626, WVRHC.

${ }^{78}$ Link, Roots of Secession, 240-243.
} 
ballot-box" would solely determine whether the Old Dominion would remain in the Union or join the Confederacy. The extralegal actions undertaken by secessionists lacked legitimacy because they occurred without popular sanction. Now northwesterners existed in a political purgatory as this "fearful emergency" unfolded across the nation and the state. To help northwesterners' navigate this fluid and hostile political climate, Carlile endorsed the passage of a resolution that enjoined residents to "appoint...their wisest, best, and discreetest men" for a meeting set to convene in Wheeling in May. Northwesterners would find a democratic path out of this national crisis. ${ }^{79}$

Not all northwesterners supported Carlile's "Clarksburg Convention" or expressed dismay about the convention's decision, however. Upon returning to Wheeling, Chester Hubbard remarked that the "secession element is very active" in the city and that a tenuous "peace" existed between unionists and secessionists. ${ }^{80}$ Adding to the tense atmosphere in Wheeling, the Daily Union maintained that "every citizen, native and naturalized" must "acknowledge allegiance to Virginia alone." "Self preservation and the best interests of the State" required this unquestioned fealty toward Virginia. ${ }^{8182}$ A Parkersburg resident remarked that though a "large majority" supported the Union, a "very considerable minority of as rabbid secessionists as could be found in South Carolina" resided in Wood County. These secessionists

\footnotetext{
${ }^{79}$ A State of Convenience: The Creation of West Virginia, "Clarksburg Convention," West Virginia Archives \& History [http://www.wvculture.org/history/statehood/clarksburgconvention.html][accessed 24 June 2015].

${ }^{80}$ Chester Hubbard to William Hubbard, 21 April 1861, Hubbard Family Papers, A\&M 805, WVRHC.

${ }^{81}$ Daily Union [Wheeling], May 7, 1861, 2.

${ }^{82}$ The fealty of immigrants to either the Confederacy or the Union represented a contentious issue in the Northwest. One Confederate writer believed that the immigrant community around Wheeling - many of whom had remained loyal to the federal government - should impress upon other southerners the need to restrict suffrage to only nativeborn citizens. "Wherever foreigners settle together in large numbers, there universal suffrage will exist-for they will not become slaveholders." The author pinpointed the communities of "St. Louis, Louisville, north-western Virginia, and eastern Tennessee" where such a phenomenon had unfolded. To prevent the establishment of future such hostile communities, the author recommended that "no foreigners, immigrants hereafter, should ever exercise the right of suffrage." "The Perils of Peace," Debow's Review, 31, no. 4 and 5 (October-November 1861): 397. For an exploration of Germans in Wheeling during the Civil War, see Fones-Wolf, "Caught Between Revolutions": 1947.
} 
were "openly and secretly plotting the overthrow" of the federal government, he warned. ${ }^{83}$ Upshur County farmer Lewis Lunsford observed that those "who love Virginia[,] her laws[,] institutions[,] and dictations in this particular vicinity, are surrounded...by...people whose Northern feeling and Abolition sentiments are proclaimed among us with impunity." These unionists enraged Lunsford. Such northwesterners mocked their birthright and empowered "Lincoln and his Abolition allies," men who had "usurped the powers of...[the] Constitution." Lunsford feared that his Union neighbors would "put their threats into execution" and, in so doing, upset the state's "laws" and "institutions." 84

The convention's adoption of the Ordinance of Secession further illustrated that the Northwest remained divided, not monolithic. Taylor County farmer Fabricius Cather witnessed this division firsthand. Unionists "hissed down" secessionist Samuel Woods during his speech and showered "secession troops" mobilizing in Grafton with "hisses \& groans." 85 In Wellsburg, John G. Jacob noted that a "formidable and active body of secessionists" operated in "every community" across the region, including Hancock County. ${ }^{86}$ On April 26, four days after Carlile's "Clarksburg Convention," secessionists gathered in the city for a "STATES-RIGHTS MEETING" to decry northerners' "long continued hostility" against the slaveholding South. These residents applauded the work of their elected representatives in Richmond in removing Virginia from a nation ruled by a "despot" who wielded the "power of a military Emperor" against the

\footnotetext{
${ }^{83}$ Samuel Peden to Waitman T. Willey, 30 April 1861, Charles H. Ambler Collection, A\&M 122, Box 10, Folder 6, item 320, WVRHC. [emphasis in original]

${ }^{84}$ Lewis Lunsford to Jonathan M. Bennett, 8 May 1861, Jonathan M. Bennett Papers, A\&M 32, Box 20, WVRHC and 1860 U.S. Federal Census: Upshur, Virginia; Roll: M653_1382; Page: 308; Image: 315; Family History Library Film: 805382 [Ancestry.com][accessed 25 June 2015].

${ }^{85}$ Diary entry, 11 May 1861 and 22 May 1861, Fabricius A. Cather, Civil War Diaries, A\&M 3633, WVRHC.

${ }^{86}$ Wellsburg Weekly Herald, May 10, 1861, 2. This body of secessionists continued to operate well into 1861. Jacob noted that secessionists who "are fully as virulent as those further South" roamed Hancock County, identifying such men as those who "have imbibed strong southern and pro-slavery principles, which they feel it incumbent upon them to promulge [sic[ and defend." Wellsburg Herald, August 23, 1861, 2.
} 
South's "free government and enlightened institutions." Northwestern unionists deserved equal condemnation. Such men disparaged the memory of the American Revolution and their birthright as Virginians. Further, their desire to detach the Northwest from Virginia and become a "fragmentary bastard corner of Pennsylvania or Ohio" or an independent "helpless, renegade community" would generate "civil strife" and expose "families and...property to murder, rapine, fire, and general devastation." Carlile's attempt to establish a "Provisional Government" in Wheeling lacked "law or authority" from the people and would surely fail. Accordingly, these northwestern secessionists "utterly condemn[ed] the proposition to divide the State, and...loath and abhor the diabolical manner in which it is proposed." ${ }^{\prime 87}$

This secessionist meeting in Clarksburg contributed to what Waitman Willey considered unionists' "embarrassed position in the N. West." His return to Morgantown convinced him that secession had "greatly divided" residents, creating doubt about whether the Northwest would remain in the Union or join the Confederacy. "[W]e do not now know, how strong the Union sentiment is in the N. Western counties," he lamented. Willey's uncertainty reflected the region's fluid political climate, as he remained unsure whether his constituents would ratify or reject the secession ordinance. He believed that the upcoming vote on the Ordinance of Secession would provide a "reliable index" in measuring residents' unionism but worried that overwhelming support for ratification would prove disastrous for unionists. "If we are in a minority in the N. West, what shall we do?" A lopsided defeat of the ordinance, though, could assist in securing a division of the state. Though the "idea of a division of the state is new to the people," Willey expressed confidence that Virginia's allegiance with the Confederacy would deepen that desire. Still, he cautioned against pursuing any "further and ultra movements" if

87 “States-Rights Meeting in Harrison,” Broadside o.s., 1861: 59, VHS. 
residents' demanded division, including against slavery. Willey was not prepared to propose slavery's abolition in a new state. ${ }^{88}$

Further dividing northwesterners was news from Richmond that on April 26 the convention had removed the tax restrictions on African American slaves. Many secessionists, after securing the passage of the secession ordinance, supported full taxation on slave property to foster unity among Virginians and heal the sectional divisions the convention had exposed. Jeremiah Morton of Greene County and George W. Randolph of Richmond, both slaveholders, spearheaded this movement to equalize taxation. Morton maintained that western delegates would return home "triumphantly" having secured a constitutional guarantee of equal taxation on black slaves, a measure that would further promote a "united" Virginia during this national crisis. ${ }^{89}$ Randolph concurred, arguing that western delegates, notably those who ratified the secession ordinance, deserved a "satisfactory adjustment" on taxation. ${ }^{90}$

Some northwesterners agreed with secessionists' arguments. Benjamin Wilson of Harrison County, who remained in Richmond after the vote on secession, believed that this amendment would promote "unity" in a region that had expressed "dissatisfaction" with secession. Indeed, removing the tax restrictions on African American slaves would "defeat" those who used such exemptions to foment "discord and division" in the Northwest. ${ }^{91}$ The Fairmont True Virginian agreed. With easterners paying "three times as much tax" as westerners, Virginia would be "one and indivisible." 92 The Republican Wellsburg Herald, however, considered the amendment one of the convention's "artful dodges" designed to make

\footnotetext{
${ }^{88}$ Waitman T. Willey to Chester Hubbard, 6 May 1861, Hubbard Family Papers, A\&M 805, WVRHC. [emphasis in original].

${ }^{89} 1861$ Proceedings, 4: 534

${ }^{90} 1861$ Proceedings, 4: 228.

911861 Proceedings, 4: 539.

${ }^{92}$ Fairmont True Virginian, May 4, 1861, 2.
} 
the secession ordinance more palpable to northwestern voters. Still, the Republican organ worried that "many good Union men" would fall into the "trap" set by secessionists, specifically that unionists would be tricked into voting in favor of equalize taxation and the secession ordinance. $^{93}$

The Wellsburg Herald and unionists across the Northwest looked toward the First Wheeling Convention for guidance during this fluid political climate. Convened on May 13, the convention included over 400 attendees, with a handful of northwestern counties providing over half the delegation. ${ }^{94}$ Divisions immediately surfaced among delegates over what mode of redress northwesterners should pursue and when to place such plans into motion. Parkersburg lawyer John J. Jackson "opposed... any definite or decisive action" on the part of the convention, arguing that moving for a division of the state was "premature," "revolutionary," and "altogether unwise" until northwesterners had "exhausted" all other options. Jackson urged the publication of resolutions expressing the "wrongs" suffered by the Northwest while exhorting delegates to campaign against the secession ordinance's ratification. ${ }^{95}$ Carlile rejected Jackson's cautious nature and his "paper resolves." "[L]et us show our loyalty to Virginia and the Union," he declared, "and let us maintain ourselves in the Union at every hazard." Such prompt action and determination among unionists would furnish clear evidence of residents' fealty toward the federal government, a loyalty that would compel the government to provide northwesterners military assistance. ${ }^{96}$ While Brooke County delegate and merchant Campbell Tarr agreed with

\footnotetext{
${ }^{93}$ Wellsburg Herald, May 24, 1861, 3.

${ }^{94}$ MacKenzie, "Fifth Border State," 139-141 and Tarter, Grandees of Government, 218.

${ }^{95}$ Virgil A. Lewis, How West Virginia Was Made: Proceedings of the First Convention of the People of Northwestern Virginia at Wheeling, May 13, 14, and 15, 1861, and the Journal of the Second Convention of the People of Northwestern Virginia at Wheeling, which assembled June 11th, 1861 and Continued in Session until June 25th. Adjourned until August 6, 1861. Reassembled on that date, and continued in session until August $21^{\text {st }}$, when it adjourned sine die (Charleston, WV: News-Mail Company Public Printers, 1909), 42. [hereafter cited as Lewis, How West Virginia Was Made].

${ }^{96}$ Lewis, How West Virginia Was Made, 43-44.
} 
Carlile's position, Willey stood with Jackson, arguing that residents looked to the convention for a thoughtful, not a hasty, response. ${ }^{97}$

This division among delegates about the proper course for northwesterners characterized the First Wheeling Convention. As Carlile remarked, delegates evinced a "unanimous determination" to defeat the Ordinance of Secession and remain in the Union but bickered over the proper "means of resistance" against the Confederacy. ${ }^{98}$ Though Carlile maintained that dismemberment represented the "only legal, constitutional remedy" available to residents during this crisis, others disagreed. ${ }^{99}$ Clarksburg lawyer John J. Davis avowed that "hasty action would not do," and prayed that Virginians would defeat the ordinance and keep the state "one and indivisible." 100 Constitutional requirements for creating a state from an existing state presented a formidable obstacle for dismemberment, as nearly all delegates recognized that the Virginia General Assembly would not assent to such a request. ${ }^{101}$ At the end of the convention, delegates passed a series of resolutions enjoining residents to defeat the secession ordinance, denouncing the Richmond convention's actions in severing the state's ties to the Union without first securing the "consent of the governed," and pledging their loyalty to the U.S. Constitution and federal government. ${ }^{102}$ Prior to adjournment, Carlile made one more impassioned plea for a new state. He urged the "erection of a New State," by "blood" if necessary, to help preserve Virginia's institutions. ${ }^{103}$ Willey, acting as Carlile's political and constitutional counterweight, encouraged

\footnotetext{
${ }^{97}$ Lewis, How West Virginia Was Made, 45-46 and 1860 U.S. Federal Census: District 2, Brooke, Virginia; Roll: M653_1337; Page: 531; Image: 71; Family History Library Film: 805337 [Ancestry.com][accessed 29 June 2015].

${ }^{98}$ Lewis, How West Virginia Was Made, 48.

${ }^{99}$ Lewis, How West Virginia Was Made, 50.

${ }^{100}$ John J. Davis to Anna Kennedy, 17 May 1861, Box 1, John J. Davis Family Papers, A\&M 1946, WVRHC and 1860 U.S. Federal Census: Clarksburg, Harrison, Virginia; Roll: M653_1351; Page: 743; Image: 233; Family History Library Film: 805351 [Ancestry.com][accessed 29 June 2015].

${ }^{101}$ John E. Stealey III, West Virginia's Civil War-Era Constitution: Loyal Revolution, Confederate CounterRevolution, and the Convention of 1872 (Kent, OH: Kent State University Press, 2013), 73.

${ }^{102}$ Lewis, How West Virginia Was Made, 63-64.

${ }^{103}$ Lewis, How West Virginia Was Made, 65-66.
} 
northwesterners to first "kill" the secession ordinance at the ballot box; a constitutional path would emerge from this action and guide northwesterners to safety. Though Virginia's membership in the southern confederacy appeared as a fait accompli, dismemberment still appeared possible but not inevitable. ${ }^{104}$

The First Wheeling Convention's missive following the proceedings reflected this division concerning statehood and the overall precarious situation northwestern unionists occupied. Delegates avoided any mention of the Richmond Convention's recent removal of tax restrictions on African American slaves, afraid that even a passing reference to that action would legitimize the convention's other initiatives. Delegates carefully chose their words concerning slavery, too, avoiding avoided any discussion of African American slavery. Rather, the convention used the word "slavery" to elucidate the Richmond convention's recent activities. "Eastern despots" had "tyrannized over" residents and had attempted to "enslave" northwesterners by removing Virginia from the nation without the people's consent. This "crime" had robbed white northwesterners of their political and constitutional rights. Between the First Wheeling Convention's conclusion and the commencement of another convention set to convene in early June, delegates urged continued resistance to the "disunion majority" assembled in Richmond. Such resistance would demonstrate to Virginia authorities that white northwesterners would not be dragged into the Confederacy like black slaves. ${ }^{105}$

The results of voting on the secession ordinance and taxation amendment on May 23 provided mixed results for northwestern unionists. Eleven northwestern counties ratified the Ordinance of Secession while extreme northwestern counties along the Ohio and Pennsylvania borders returned solid majorities against secession. Even in these counties, though,

\footnotetext{
${ }^{104}$ Lewis, How West Virginia Was Made, 66-70.

${ }^{105}$ Lewis, How West Virginia Was Made, 72-76.
} 
northwesterners cast ballots in support of the ordinance. ${ }^{106}$ Over one-hundred residents voted for secession in Brooke County, while twenty-three ratified the ordinance in Hancock County. In his History of Brooke County, John G. Jacob recognized that a "very strong southern element" existed in the county. The "doctrine of States rights," he observed, "had as staunch advocates" in Wellsburg as in Richmond. ${ }^{107}$ The Wellsburg Herald lamented that "so large a proportion" of "misguided" residents had become "traitors" to the United States. Such citizens deserved to be recognized, the newspaper determined; the editors printed the names of those who voted in favor of the ordinance. ${ }^{108}$

In Ohio County, the Daily Intelligencer undertook a similar action against secessionists. Over one-hundred and fifty Virginians, including eighty-one in Wheeling, voted to ratify the ordinance. The Republican Daily Intelligencer printed the broadside "Traitors in Wheeling," identifying those who had voted for secession. These secessionists often had close political or economic ties to state authorities in Richmond, and the prospect of a divided Virginia threatened those ties. ${ }^{109}$ Scattered newspaper reports suggest that though unionists defeated the secession ordinance in most northwestern counties, a strong secessionist element existed in each county. ${ }^{110}$

\footnotetext{
${ }^{106}$ Curry, A House Divided, 48. The eleven northwestern counties that voted to ratify the Ordinance of Secession were Barbour, Braxton, Clay, Gilmer, Nicholas, Pocahontas, Randolph, Roane, Tucker, and Webster.

${ }^{107}$ Jacobs, History of Brooke County, 156-157.

${ }^{108}$ Wellsburg Herald, May 31, 1861, 2. In Brooke County, 721 voters rejected the secession ordinance while 109 supported it. In Hancock County, 744 voted against the ordinance and 23 voted in favor. George Fitzhugh agreed with Jacob that a strong secession element friendly to the South resided in Hancock County. "The people of Brooke county, in the midst of the Pan Handle, are as true to the South as the people of South Carolina," Fitzhugh declared. He blamed the "people of Wheeling, the lower order of tradespeople, whose Bible is the ledger" for fomenting opposition to the Confederacy. George Fitzhugh, "Conduct of the War," Debow's Review, 32, no. 1 and 2 (JanuaryFebruary 1862): 145.

${ }^{109}$ Daily Intelligencer, May 25, 1861, 3 and Fones-Wolf, “Traitors in Wheeling”: 75-95. The official vote for the secession ordinance in Ohio County was 159 for, 3,368 opposed.

${ }^{110}$ The Wellsburg Herald printed results that it considered "nearly correct, [with] some of the figures being official." In Marshall County, 1,993 voted against secession while 142 voted in favor. Secessionist Leonard S. Hall's county of Wetzel voted against the ordinance, 790 to 180. Vote totals against secession in Monongalia and Preston Counties were similar, with 2,148 to 110 opposed in the former and 2256 to 63 opposed in the latter. Harrison County, home of John Carlile, witnessed a tighter contest but still a comfortable Unionist majority. While 1,691 residents voted against secession, 694 voted to ratify it. In Wood County, 1,955 opposed secession while 257 supported it. Wellsburg Herald, May 31, 1861, 2. Arguably, Richard Curry's exploration of the statehood
} 
But with statewide approval of the ordinance, this northwestern secession element would likely receive aid and support from Richmond. The Northwest would continue to be a divided region.

Three days after the vote on the secession ordinance and tax amendment, the federal government responded to unionists' pleas. Major-General George B. McClellan led Union troops into Wheeling to protect ostracized unionists and secure the region's railroads and waterways for transporting troops and matériel. ${ }^{111}$ McClellan ordered his soldiers to respect "persons and property," to be merciful to "misguided" secessionists, and allow the "loyal men of Western Virginia...to organize and arm." ${ }^{112}$ McClellan fashioned himself as northwesterners' savior from the "machinations of a few factious rebels in your midst." These rebels had prevented men from "expressing your loyalty at the polls" and would attempt to make Unionists "yield to their schemes and submit to the yoke of the traitorous conspiracy" of the Confederate States. McClellan emphasized that northwesterners' constitutional and personal rights would be "religiously respected" by the federal government. Chief among such property rights was slaveholding. Though secessionists maintained that the federal government would wage war on slavery, McClellan denied such rumors. The federal government would "abstain from all such interference" on slavery, but would use its "iron hand" to "crush any attempt at insurrection" on the part of slaves or secessionists. ${ }^{113}$

movement provides the closest approximation to the vote on the secession ordinance. He estimates that over 30,000 northwesterners voted against the ordinance while slightly over 10,000 voted in favor. Curry, A House Divided, 142-144. Missing vote totals on the ad valorem tax amendment likewise hamper further analysis on that subject. John E. Stealey reports that there are no extant voting results for fifteen counties in present-day West Virginia: Brooke, Doddridge, Hancock, Jackson, McDowell, Marion, Marshall, Monongalia, Pleasants, Preston, Ritchie, Roane, Taylor, Wetzel, and Wood. Still, in present-day West Virginia, Stealey finds that 28,037 voted for the amendment, while 2,934 opposed it. Stealey, West Virginia's Civil War-era Constitution, 69.

${ }^{111}$ William G. Thomas, The Iron Way: Railroads, the Civil War, and the Making of Modern America (New Haven: Yale University Press, 2011), 74 and MacKenzie, "Fifth Border State," 168.

${ }^{112}$ George B. McClellan, quoted in Curry, A House Divided, 55.

${ }^{113}$ George B. McClellan to the Union Men of Western Virginia, 26 May 1861, reprinted in The Civil War Papers of George B. McClellan: Selected Correspondence, 1860-1865, ed. Stephen W. Sears (New York: Ticknor \& Fields, 1989), 26. 
McClellan's presence and rhetoric calmed unionists' fears. ${ }^{114}$ The federal government extended shelter and protection to besieged unionists while respecting the property rights of all citizens. Willey later hailed McClellan's respect for slaveholders' rights, noting the "supreme satisfaction" northwesterners' felt as the general vowed to protect their chattel. ${ }^{115}$ McClellan's aid was critical as unionists reconvened in Wheeling in early June to discuss the reorganization of the state government and the propriety of dismemberment. Though a month removed from the First Wheeling Convention, no consensus existed concerning a division of the state. ${ }^{116}$ This disharmony became manifest as the Second Wheeling Convention progressed. ${ }^{117}$ On June 13, two days after its commencement, the convention passed a declaration denouncing the recent actions of Virginia Governor John Letcher and the Richmond Convention in denying Virginians an opportunity to ratify or reject the secession ordinance prior to the state levying war against the Union. ${ }^{118}$ Northwesterners considered the actions separating the state from the Union as enacted

\footnotetext{
${ }^{114}$ John J. Davis believed that the "presence of Federal troops" in the Northwest "saved the Union men from being crushed \& persecuted to death by the Secessionists." He noted that prior to McClellan entering the Northwest, Union men in Taylor and Barbour counties "were persecuted most shamefully," with some "imprisoned" and others "forced to take the oath of allegiance to the Southern Confederacy." John J. Davis, quoted in F. Gerald Ham, "The Mind of a Copperhead: Letters of John J. Davis on the Secession Crisis and Statehood Politics in Western Virginia, 1860-1862," West Virginia History, 24, no. 1 (October 1962 to July 1963): 99.

${ }^{115}$ Waitman T. Willey, Speech of Hon. W.T. Willey of Virginia, on the Object of the War; Delivered in the Senate of the United States, December 19 and 20, 1861 (Washington, D.C.: Congressional Globe Office, 1862), 5.

${ }^{116}$ Kingwood Chronicle, June 8, 1861, 2. George and Amos Row, publishers of the Kingwood Chronicle in Preston County, argued that the Northwest's "position is to adhere to the old State Constitution." Virginia officials had vacated congressional and state offices, mandating that northwesterners fill those positions while maintaining its presence in the Union. The actions of eastern Virginians, the publishers concluded, required northwesterners to assume governing responsibilities, not to create a new Virginia. Part of northwesterners' hesitancy to create a new state may have reflected the success of Union forces in the region. Union victories across the Northwest, including at Philippi and, later, Rich Mountain, may have persuaded some northwesterners that the Civil War would be shortlived. Any drastic change advocated by residents could be abandoned if conflict ceased, leaving pro-statehood northwesterners in an awkward political position once relations with eastern Virginia returned to antebellum status.

${ }^{117}$ Unlike the first convention, more of the 105 delegates hailed from Virginia while slaveholding continued to be an important characteristic for some members. MacKenzie, "Fifth Border State," 148. MacKenzie concludes that ten delegates owned a total of fifty-one slaves, with Lewis Ruffner of Kanawha County owning half of those slaves. ${ }^{118}$ John Letcher disagreed with the convention's argument concerning his and the Richmond Convention's antidemocratic behavior. In a letter "To the People of Northwestern Virginia," Letcher maintained that the "sovereign people of Virginia... by their own free choice, have... severed the ties" to the federal government. The "majority is against you," Letcher argued, and thus it became the "duty of good citizens to yield to the will of the State." The Virginia governor called upon northwesterners to reflect upon their shared birthright, heritage, and memories with eastern Virginians, their brethren who had recently displayed their "magnanimity" in equalizing
} 
"without authority" and therefore "void." 119 The convention reestablished the offices of governor and lieutenant governor and elected delegates to meet in a legislative body in the city. Delegates selected Francis H. Pierpont of Marion County and Daniel Polsley of Mason County for governor and lieutenant governor, respectively. ${ }^{120}$

Pierpont's two addresses to the convention reflected northwestern unionists' concern with protecting slavery and democracy. Confederates declared that "the people are not the source of all power," an axiom that represented the antithesis of what northwesterners had argued over the preceding decades. These traitors maintained that only the "educated class" should possess political representation, not "laboring classes." 121 Importantly, Pierpont denied that the "protection of negro slavery was the great object" of the war. The blame for the war rested on southern patricians. These aristocrats had grown "dissatisfied with the Union" and used slavery as a "pretext" to overthrow the current government and institute "one more suited to their tastes and habits of life.” By branding southern patricians, not slavery, for instigating the war, Pierpont disarmed those who may have considered action against the institution a necessary prerequisite in destroying the Confederacy. Northwesterners should concern themselves with quelling the rebellion and reorganizing the state government, Pierpont declared, not in interfering with African American slavery. ${ }^{122}$

taxation. John Letcher, "To the People of Northwestern Virginia," 17 June 1861, John Letcher papers, Mss1 L5684 a FA2, Series 6, Folder 401, VHS.

${ }^{119}$ Lewis, How West Virginia Was Made, 86-87.

${ }^{120}$ Lewis, How West Virginia Was Made, 92, 140-141.

${ }^{121}$ Lewis, How West Virginia Was Made, 144-145.

${ }^{122}$ A State of Convenience: The Creation of West Virginia, "Proceedings of the Second Wheeling Convention, June 17, 1861," West Virginia Archives \& History: West Virginia Division of Culture and History [http://www.wvculture.org/history/statehood/wheelingconvention20617.html][accessed 2 July 2015]. Waitman Willey supported Pierpont's assertion that southern planters and aristocrats who despised democracy instigated the war. Willey argued that "dissatisfaction with the principles and operation of democratic government" and a "hostility to the simplicity and equality of republican institutions" drove these southern patricians to secede and declare war on the United States. Willey, Object of the War, 11. 
The motion to reorganize the state government and not to pursue dismemberment divided the convention. John Carlile, a passionate and ardent supporter of a separate state a month earlier, expressed more caution during this latter meeting. He confessed that he "first started the little stone down the mountain" but now believed it prudent to "apply the rubbers to other gentlemen" who advocated immediate division. ${ }^{123}$ Chester Hubbard of Ohio County agreed, arguing that delegates were "not here to create a State, but to save one."124 Other delegates insisted that the convention must consider constitutional obligations, especially because the federal government had provided the necessary security for protecting this convention. ${ }^{125}$

Delegates advocating immediate dismemberment were few and held little sway in the convention. Monongalia delegate George B. Dorsey characterized dismemberment as a "dire necessity" that would permanently separate two "entirely antagonistic" peoples. Virginia's "history" provided sufficient evidence to Dorsey that western Virginians' shared few, if any, “interests" with their eastern brethren. ${ }^{126}$ Dorsey and fellow pro-statehood members failed to convince their colleagues about the immediate need for separation, however. John J. Davis believed that "Black Republicans" were the "strongest supporters and advocates" for immediate separation, a scheme that appeared more of a "revolution" than a "legal, constitutional action."127

\footnotetext{
${ }^{123}$ Lewis, How West Virginia Was Made, 125.

${ }^{124}$ Lewis, How West Virginia Was Made, 123.

${ }^{125}$ Lewis, How West Virginia Was Made, 106-107, 110-111. John D. Nicholls of Brooke County and Chapman J. Stuart of Doddridge cautioned delegates about undermining constitutional principles in creating a new state out of an existing state. Peter G. Van Winkle of Wood County worried about the boundaries of the new state being drawn during the early stages of the war, especially when secessionists still controlled some western counties.

${ }^{126}$ Lewis, How West Virginia Was Made, 104-106.

${ }^{127}$ John J. Davis to Anna Kennedy, 13 June 1861, John J. Davis Family Papers, A\&M 1946, Box 1, WVRHC. Davis admitted that he "felt Virginian all over" during these proceedings, especially when that "negro loving" abolitionist John C. Underwood applied for admission to the convention. [emphasis in original]
} 
Though the Second Wheeling Convention agreed to consider separate statehood at a future meeting in August, divisions and accusations prevented delegates from cohering on this issue. ${ }^{128}$ The divisions expressed by delegates concerning separation should not be surprising or that advocates for division remained in the minority. Over the preceding decades, northwesterners wielded dismemberment as a threat against eastern legislators who had abused political power and refused to extend political equality to all white men. Even when northwesterners discussed dismemberment, opposing voices noted serious political, economic, and constitutional issues could derail the movement. Common bonds of heritage, history, and religion further dampened such talk. The 1851 Constitution extinguished any discussion of disunion in the state, as northwesterners finally achieved the equality that had been denied to them. The onset of war, though, challenged residents' fealty toward the state. Secessionists' extralegal maneuvers infuriated northwesterners who interpreted such actions as that of a master compelling his black slave. Questions loomed in northwesterners' minds. Could northwesterners trust these secessionists if they occupied the same body politic following the war? Would a decisive Union victory displace these secessionists from positions of power and place northwesterners in control of the state government? How would secessionists' actions impact slavery? Could northwesterners' satisfy constitutional requirements if they desired division? These questions confounded northwesterners. Lacking sufficient answers to these questions, most northwesterners preferred resistance to secessionists, not revolution, in 1861.

\footnotetext{
${ }^{128}$ Even the Republican Wellsburg Herald, an advocate for separate statehood, realized that "common sense" and the "natural run of events" convinced delegates to postpone talk of division. The newspaper hoped that once "affairs take a more settled shape," delegates and northwesterners would be able to revisit this question. Wellsburg Herald, June 14, 1861, 2. A few weeks later, John G. Jacob, editor of the newspaper, argued that "if the new State is to be a free State, we are for it; otherwise, we are for the old State." He lamented that an element existed in the region that "still consider slavery as the one thing needful for the salvation of the State." Wellsburg Herald, July 19, 1861, 2. [emphasis in original]. See also Wellsburg Herald, July 26, 1861, 2.
} 
When the Second Wheeling Convention reconvened in early August, ${ }^{129}$ Confederate fortunes had improved immensely. Confederate victories, notably at Manassas in late July, persuaded many northwesterners that the war would not end quickly and possibly without a decisive Union victory. ${ }^{130}$ A Confederate victory or truce between the two belligerents would create an uncertain future for northwestern unionists and for slavery and democracy in the region. ${ }^{131}$ Faced with improving Confederate military prospects, delegates at the Second Wheeling Convention further distanced the Northwest from the reach of the Richmond government, declaring all constitutional, legislative, and policy actions enacted by that body "illegal, inoperative, null, void, and without force or effect."132 On the convention's seventh day, the Committee on a Division of the State offered its ordinance for dividing the state, maintaining that a division would improve the "social, commercial and political condition" of western Virginians. Though more delegates supported dismemberment than a month prior, dissenting voices still existed. ${ }^{133}$

\footnotetext{
${ }^{129}$ During the interim between the Second Wheeling Convention in June and in August, the reorganized government convened in Wheeling from July 1-26. On July 4, President Lincoln informed Congress that he recognized the Wheeling government as the legitimate government for Virginia. This recognition from Lincoln aided the convention's work. Delegates elected Waitman T. Willey and John Carlile as U.S. Senators for Virginia, replacing the seats vacated by James M. Mason and Robert M.T. Hunter. This reorganized government of eight state senators and thirty-two house delegates focused primarily on western Virginia's military and financial matters. Only during the latter part of the session did the General Assembly take up the question of a division. The House of Delegates voted down the measure while the state senate tabled it. Every delegate except one returned in August when the Second Wheeling Convention reconvened. Tarter, Grandees of Government, 220 and A State of Convenience: The Creation of the State of West Virginia, "Legislature of the Reorganized Government of Virginia meets in Extra Session, July 1-26, 1861," West Virginia Archives \& History: West Virginia Division of Culture and History [http://www.wvculture.org/history/statehood/statehood08.html][accessed 3 July 2015].

${ }^{130}$ Charles H. Ambler and Festus P. Summers, West Virginia: The Mountain State (Englewood Cliffs, NJ: PrenticeHall, 1958), 204.

${ }^{131}$ William G. Brown expressed such fears as the Second Wheeling Convention adjourned in late June. Brown argued that securing an "early division of the State" was of the "utmost importance," believing that the antipathy between eastern and western Virginians made reconciliation impossible. This project needed to be completed "before the parties are done fighting," he emphasized, and further hoped that a new state would be a "home for Union men who may be driven from other parts of the State.” William G. Brown to Francis H. Pierpont, 24 June 1861, Francis Harrison Pierpont Papers, A\&M 9, Box 2, Folder 23, WVRHC. [emphasis in original].

${ }^{132}$ Lewis, How West Virginia Was Made, 195.

${ }^{133}$ Lewis, How West Virginia Was Made, 204.
} 
Committee chairman James G. West, a farmer from Wetzel County and former opponent of the statehood movement, dismissed concerns that fluid and hostile boundaries between union and secession counties should be resolved before creating a state. ${ }^{134}$ Marion County merchant John S. Barnes, though, emphasized the "impropriety" of creating a new state, arguing that its creation should be done in "accordance with the Constitution." Would Congress admit Western Virginia on a "mere technicality?" Barnes also stressed that residents in numerous counties included in the initial boundaries of the state had embraced secession only months earlier. Barnes urged his colleagues to first exhaust "all peaceful and legal means of obtaining a separation," even if that meant consulting the "whole state." The war, he concluded, had been waged over the "maintenance of the Constitution," thereby requiring unionists to strictly adhere to constitutional principles lest their actions undermine the federal government. ${ }^{135}$ But Wetzel County farmer Reuben Martin asserted that a new state would manifest the "line between us" that the "God of nature" had drawn between eastern and western Virginians. Northwesterners, in fashioning a new state, would simply be following Providence's will. ${ }^{136}$

The issue of slavery entered the discussion as delegates continued to debate dismemberment. Andrew F. Ritchie, a farmer from Marion County, believed that the convention's effort to create a new state would produce irreparable harm for the federal government. Dividing Virginia, he asserted, would be a "violation of the spirit, if not the letter of the [Federal] Constitution." The Constitution provided specific instructions for creating a new state; western Virginia failed to satisfy those requirements. An attempt to apply to Congress for

\footnotetext{
${ }^{134}$ Lewis, How West Virginia Was Made, 206-208 and 1860 U.S. Federal Census: Wetzel, Virginia; Roll: M653_1384; Page: 29; Image: 33; Family History Library Film: 805384 [Ancestry.com][accessed 5 July 2015].

${ }^{135}$ Lewis, How West Virginia Was Made, 208-210 and 1860 U.S. Federal Census: District 4, Marion, Virginia; Roll: M653_1361; Page: 583; Image: 143; Family History Library Film: 805361 [Ancestry.com][accessed 5 July 2015]. ${ }^{136}$ Lewis, How West Virginia Was Made, 210-211 and 1860 U.S. Federal Census: Wetzel, Virginia; Roll: M653_1384; Page: 154; Image: 158; Family History Library Film: 805384 [Ancestry.com][accessed 5 July 2015].
} 
statehood would "embarrass the action" of the federal government in its attempt to "put down the rebellion." Attempting to create a state without fully addressing the "slavery question," he emphasized, would "only create controversy in Congress." Controversy would also extend into the Northwest, where a "divided sentiment" existed among residents concerning the institution. Republicans, still an alien organization to most residents, would not rest until slavery ceased to exist in the region, Ritchie insisted, thereby creating a division that would destroy the reorganized government. The Lincoln Administration had not interfered with slavery or the rights of slaveholders in its war against the Confederacy; how could western Virginians inaugurate or tolerate such action in their own state ${ }^{137}$

Other delegates agreed with Ritchie's rationale concerning slavery. Fontain Smith, a lawyer from Marion County, maintained that geography and climate could resolve the question of slavery in western Virginia, freeing delegates from any action on the issue. Still, African American bondage was "constitutionally right," he declared. ${ }^{138}$ Charles S. Lewis, a slaveholder and lawyer in Harrison County, resisted secession because he believed the Confederacy "would strike a death blow at the institution," not save it. Lewis dismissed the "ravings of the abolitionists" in demanding emancipation and cautioned delegates about the "danger" of turning western Virginia into a free state. Instead of permitting the "emancipationist...[to] raise his head

\footnotetext{
${ }^{137}$ Lewis, How West Virginia Was Made, 218-220 and 1860 U.S. Federal Census: District 4, Marion, Virginia; Roll: M653_1361; Page: 608; Image: 168; Family History Library Film: 805361 [Ancestry.com][accessed 5 July 2015]. Ritchie also presented to the convention a letter from U.S. Attorney General Edwin Bates who advised the convention to avoid introducing "any new elements of revolution" and to adhere to constitutional outlines for creating a new state. Bates feared that erecting a new state from an existing one without the consent of the latter would validate a "new and hazardous experiment." Edwin Bates to A.F. Ritchie, 12 August 1861, quoted in Lewis, How West Virginia Was Made, 219-220.

${ }^{138}$ Lewis, How West Virginia Was Made, 221-222 and 1860 U.S. Federal Census: District 7, Marion, Virginia; Roll: M653_1361; Page: 710; Image: 272; Family History Library Film: 805361 [accessed 5 July 2015][accessed 5 July 2015].
} 
in our midst," Lewis urged delegates to allow the "silent laws of political economy" to determine slavery's fate. ${ }^{139}$

The slavery question continued to vex delegates. Wood County delegate Arthur I. Boreman asserted that a constitution submitted to Congress that contained no provision for ending slavery would be rejected. Such an action by the Republican legislature would "foment such an excitement in Western Virginia as was never witnessed before." Could this “excitement" evolve into secessionism? ${ }^{140}$ Ohio County banker Daniel Lamb agreed with Boreman's conclusion. Though Lamb admitted that the territory proposed for the new state contained a small slave population in comparison with eastern Virginia, he became concerned that this statehood movement would evolve into an "abolition movement." If the convention petitioned Congress for statehood with slavery, Republicans would deny admittance. Why "push such a question upon the councils of the nation" while the federal government waged war, Lamb wondered. ${ }^{141}$ Lieutenant Governor Daniel Polsley maintained that "he was as good a pro-slavery man as any one in the State," but confessed that he would abandon slavery if it meant the

\footnotetext{
${ }^{139}$ Lewis, How West Virginia Was Made, 224-225; 1860 U.S. Federal Census: Millford, Harrison, Virginia; Roll: M653_1351; Page: 767; Image: 257; Family History Library Film: 805351 [Ancestry.com][accessed 5 July 2015]; and, 1860 U.S. Federal Census: Slave Schedules - Harrison County, VA [Ancestry.com][accessed 5 July 2015]. Waitman Willey and Taylor County merchant and fellow slaveholder John S. Burdett agreed with Lewis. In a speech in the U.S. Senate, Willey argued that Virginians and all Americans should "leave slavery where the Constitution and laws have placed it." Burdett reaffirmed his position as a "pro-slavery man," noting that he had "bought and sold a few Negroes" over the past years. He also maintained that the "way to perpetuate the institution is to preserve the Union of the states," especially against that "damnable heresy of secession." Willey, Object of War, 11; John S. Burdett to Waitman T. Willey, 27 August 1861, Charles H. Ambler Collection, A\&M 122, Box 10, Folder 7, item 347, WVRHC; 1860 U.S. Federal Census: Taylor, Virginia; Roll: M653_1381; Page: 508; Image: 12; Family History Library Film: 805381 [Ancestry.com][accessed 6 July 2015]; and, 1860 U.S. Federal Census - Slave Schedules: Taylor, Virginia [Ancestry.com][accessed 6 July 2015].

${ }^{140}$ Lewis, How West Virginia Was Made, 273-274.

${ }^{141}$ A State of Convenience: The Creation of West Virginia, "Proceedings of the Second Session of the Second Wheeling Convention, August 20, 1861, Mr. Lamb's Speech on the Division of the State," West Virginia Archives \& History: West Virginia Division of Culture and History [http://www.wvculture.org/history/statehood/statehood08.html][accessed 6 July 2015] and 1860 U.S. Federal Census: Wheeling Ward 5, Ohio, Virginia; Roll: M653_1368; Page: 340; Image: 348; Family History Library Film: 805368 [Ancestry.com][accessed 6 July 2015].
} 
salvation of Virginia and the federal government. ${ }^{142}$ As Republican John G. Jacob later admitted, though the Northwest was "on the margin of the slaveholding community" by 1861 , residents expressed "a good deal of interest" in the institution and its maintenance. In "various ways" and "by association" slavery impacted each and every resident, he observed. ${ }^{143}$ Jacob was correct. Though few slaves and even fewer slaveholders resided in the Northwest, the institution enjoyed broad acceptance and countless advocates. Cognizant of residents' support for slavery, delegates remained uncertain about the prospects of a new state or the institution.

When the convention adjourned on August 21, delegates passed "An Ordinance to Provide for the Formation of a New State out of a Portion of the Territory of this State" by a 5028 margin, a reflection of persistent divisions. ${ }^{144}$ Delegates tackled the issue of slavery by not addressing it at all; the ordinance made no reference to slaves or slavery. Residents would vote on the ordinance, along with a slate of delegates to attend a constitutional convention set to convene in November if the ordinance carried, on October 24. Dismemberment and the creation of the new state of Kanawha were on the horizon but without a resolution on slavery, Kanawha's admittance into the Union appeared uncertain. ${ }^{145}$

Residents remained conflicted as the October vote loomed. In a mass meeting held in Wheeling, Governor Pierpont emphasized that Confederates' "leading object...was not only to keep their negroes enslaved, but to enslave the whole working classes of the country." Securing a division of the state would save white laborers from political bondage. ${ }^{146}$ An anonymous writer in the Daily Intelligencer argued that the vote represented an "opportunity of freeing"

\footnotetext{
${ }^{142}$ Lewis, How West Virginia Was Made, 277.

${ }^{143}$ Jacob, History of Brooke County, 163.

${ }^{144}$ Other issues outside of slavery created more divisions among delegates. These included the proposed state's borders, debt assumption, and Virginia's intrastate tensions over the preceding decades. Lewis, How West Virginia Was Made, 210, 224-225, 237-238.

${ }^{145}$ Lewis, How West Virginia Was Made, 284-300.

146 Daily Intelligencer, September 26, 1861, 3.
} 
northwesterners "from the yoke of the oppressor." Virginia's "history" and "geography," notably the "mountain barriers" that no internal improvement had "hewn down or pierced," should provide sufficient evidence to all voters that eastern and western Virginia possessed divergent "interests." 147 The editors of the Daily Intelligencer believed that the "day that is to sever us from our political connection with Eastern Virginia" would soon become manifest. ${ }^{148}$ The newspaper dismissed the slavery issue, reminding readers that Kanawha's future resembled that of its free state neighbors Ohio and Pennsylvania. Regardless of future action on slavery, "natural laws" and the "irresistible march of events" would eventually make Kanawha a free state, too. ${ }^{149}$

The Wellsburg Herald expressed more concern and doubt than its fellow Republican organ. "The signs in the political heavens are unpropitious." Though optimistic about the ordinance receiving residents' approval, the newspaper believed that congressional approval for a new slave state was unlikely. A "civil war" would commence, dividing residents into those who demanded the "abolition of slavery" and those "whose rallying cry will be death to the Abolitionists." Civil war would engulf the region. ${ }^{150}$ John J. Davis, a delegate to the Second Wheeling Convention who had voted in favor of the division ordinance, "hope[d]...[that] the measure will carry with the people and relieve West Va." Still, he found the timing "inopportune during the continuance of hostilities." ${ }^{151}$ A convincing Confederate victory in the Northwest could force Davis and other unionists "to say farewell to the land of my birth" and imperil the

\footnotetext{
${ }^{147}$ Daily Intelligencer, October 8, 1861, 2.

${ }^{148}$ Daily Intelligencer, August 21, 1861, 2.

${ }^{149}$ Daily Intelligencer, October 21, 1861, 2.

${ }^{150}$ Wellsburg Herald, August 30, 1861, 2.

${ }^{151}$ John J. Davis to Anna Kennedy, 25 August 1861, John J. Davis Family Papers, A\&M 1946, Box 1, Folder 1, WVRHC.
} 
statehood movement. ${ }^{152}$ Lewis County attorney Caleb Boggess noted that a "large majority" of northwesterners favored division but worried that achieving "Congressional consent" would derail the movement. This "doubt" concerning congressional approval expanded the "diversity of opinion" already existing on the subject. Could a resolution on this issue be achieved that satisfied voters? ${ }^{153}$

The results on the division ordinance revealed residents' desire for dismemberment but presented a cautionary tale about aggressive action concerning slavery. Over eighteen-thousand residents voted in favor of the ordinance, while less than five-hundred rejected it. ${ }^{154}$ John J. Davis celebrated the "overwhelming" margin in favor of division. He "hope[d] Jeff Davis will let us depart in peace now," as the election results provided "unmistakable evidence of our unwillingness to become subjects of his." ${ }^{155}$ Though one hurdle had been cleared, several more remained with slavery being the most imposing. An anonymous writer remarked that "the people are not yet prepared for a rejection of slavery" and argued that it constituted "too great a change" for many to consider. Could a free state be realized? ${ }^{156}$ The Wellsburg Herald was "satisfied" with the results but cautioned that the issue of slavery still loomed. The Herald predicted that a "provision for gradual emancipation, would probably not abolish slavery under 25 or 30 years" in the Northwest, and instead recommended that residents let slavery perish from

\footnotetext{
152 John J. Davis to Anna Kennedy, 2 September 1861, John J. Davis Family Papers, A\&M 1946, Box 1, Folder 2 , WVRHC.

${ }^{153}$ Caleb Boggess to Waitman T. Willey, 11 October 1861, Charles H. Ambler Collection, A\&M 122, Box 10, Folder 7, item 352, WVRHC and 1860 U.S. Federal Census: Weston, Lewis, Virginia; Roll: M653_1358; Page: 186; Image: 194; Family History Library Film: 805358 [Ancestry.com][accessed 6 July 2015].

${ }^{154}$ Lewis, How West Virginia Was Made, 318. The official returns were 18,408 for and 481 opposed. As Richard O. Curry notes, in a few counties only a handful of votes were cast in the election. Raleigh, Braxton, Clay, and Hardy counties all returned totals that reflected only a fraction of the voting population. Curry suggests that enlistment in both armies along with intimidation prevented a better turnout. Curry, House Divided, 86.

${ }^{155}$ John J. Davis to Anna Kennedy, 4 November 1861, John J. Davis Family Papers, A\&M 1946, Box 1, Folder 2, WVRHC.

${ }^{156}$ Daily Intelligencer, November 4, 1861, 2.
} 
"natural decay.” Any aggressive action concerning African American bondage, including a gradual emancipation clause, threatened to derail the statehood movement. ${ }^{157}$ In Wheeling, the Daily Intelligencer appeared less concerned about the issue of slavery. The newspaper castigated those who "bring forward Mr. Nigger on all occasions, and use him as a getter up of prejudice," notably those who characterized the statehood movement as an offspring of "abolitionism, or some other obnoxious ism." The issue of slavery, the newspaper confidently predicted, would be easily resolved in the coming months. ${ }^{158}$

The Daily Intelligencer expressed a confidence concerning slavery and the upcoming constitutional convention that appeared justified. Northwestern Republicans believed that the war manifested the bitter fruits of the peculiar institution and its subversive effects on democratic government. Republican John G. Jacob recognized that the "incompatibility of African slavery with republican institutions and the development of the American idea of self-government" produced the troubles that afflicted both the nation and the state. ${ }^{159}$ The actions of the Richmond Convention and Henry Wise and his ilk in levying war against the Union prior to public ratification of the secession ordinance smacked of tyranny as it constituted an affront to republican government. Such actions, Republicans averred, reflected slavery's corrupting political influence. As the war continued and the deaths mounted, Republicans reasoned that any remaining proslavery sentiment in the Northwest would dissipate. The vote on the division ordinance further clarified and strengthened Republicans' interpretation concerning slavery and the statehood movement. Residents demanded a new state, one free from slavery's baneful reach.

\footnotetext{
${ }^{157}$ Wellsburg Herald, November 29, 1861, 2.

${ }^{158}$ Daily Intelligencer, November 12, 1861, 2.

159 Wellsburg Herald, July 26, 1861, 2.
} 
The Daily Intelligencer poorly misread northwesterners' interpretation of African American bondage, a misinterpretation that has shaped the historiographical debate concerning West Virginia statehood and the issue of slavery. Northwesterners' adhered to the Union and rejected the Confederacy not because they desired slavery's extinction; rather, residents remained committed to the Union because slavery would continue to flourish under the Stars and Stripes. The hierarchies constructed on the peculiar institution, notably racial supremacy and patriarchy, would remain inviolable in the Union. Further, northwesterners' democratic rightsrights obtained after decades of struggle and debate-would remain protected from overzealous planters who wished to stem the tide of democratic reform across the South.

The "Slave Power" that Republicans castigated existed under the guise of "King Cotton" in the Deep South and parts of eastern Virginia. But unlike in South Carolina, Alabama, or Mississippi, northwesterners believed that their constitution properly situated power in the hands of nonslaveholders while checking the power of such patrician-minded slaveholders. Empowered by universal suffrage and more legislative representation, northwestern nonslaveholders believed that they wielded tremendous political power and, in general, they were correct. Though a few grievances remained on the books that expanded slaveholders' power, nonslaveholders believed they could resolve those issues by appealing to democratic sensibilities. Few, if any, non-Republican northwesterners, though, sought to use that political power to disturb the master-slave relationship.

The preservation of the master-slave relationship and protecting democratic rights constituted northwesterners' primary objectives during the Richmond Convention, important objectives that historians have overlooked. Unionists and secessionists disagreed over the proper means of securing both but agreed that their preservation was vital. For unionists like William 
G. Brown and Waitman Wiley, the means for securing both rested on staying in the union and taxing African American slaves at their full market value. Such a move, they declared, would remove an odious feature that irritated nonslaveholders and would ultimately make the institution more secure, not endanger it. Rather than an abolitionist scheme as interpreted by some secessionists, northwesterners sought only to strengthen the institution. Northwestern secessionists generally agreed that removing tax restrictions on slaves would promote unity and raise much-needed revenue. But such actions should occur in concert with Virginia's membership in the southern confederacy. Secessionists' desire to protect their chattel persuaded many to sanction Henry Wise's extralegal actions and that of the convention as a whole, notably as the convention began to sever Virginia's bonds to the Union before the people voted on the Ordinance of Secession. Unionists bemoaned the convention's decision, interpreting the triumph of "King Cotton" over republican government and principles. Faced with a hostile populace, many northwestern delegates returned home and contemplated what move unionists could take in this national crisis.

For some northwesterners the next move was to adhere to the Union but remain loyal Virginians. The national crisis would soon be resolved through diplomacy or military conflict, and soon residents could return to their antebellum political status. Others, though, believed that secessionists' actions forced northwesterners to explore a division of the state. For decades, northwestern residents and politicians had wielded dismemberment as a signal of their dissatisfaction with their lack of political equality and as a threat to extract concessions from obdurate easterners. Now, with a war expanding in scope and cost and faced with an uncertain future, northwesterners took the next step in exploring dismemberment and statehood. But their desire for a new state did not necessarily reflect their desire for a free state, a premature 
conclusion too many historians have supported. While some residents endorsed gradual and compensated emancipation for loyal slaveholders, other northwesterners maintained that slavery must constitute the foundation for any new state. Anything short of that feature could imperil the whole movement. The unionist coalition that had steered the Northwest through the initial phases of the Civil War would be tested in the coming months on the paramount issue of the day: slavery. 
Chapter 7: (Some) Mountaineers are Always Free: Statehood and Preserving Racial Hierarchy, 1862-1863

On June 20,1863, West Virginia entered the Union as a slave state. In his inaugural address as the state's first governor, Republican Arthur Ingraham Boreman characterized the Mountain State's creation as a manifestation of the intrastate sectional tension that had threatened to dismember Virginia multiple times over the preceding years. Eastern Virginians had "always" considered the trans-Allegheny an "outside appendage" or "territory," Boreman insisted, as constitutional, political, and economic structures favored eastern Virginians at the expense of their transmontane neighbors. Empowered by the "original Constitution of the State," eastern Virginians had "collected heavy taxes from us" to construct "railroads and canals in the East" while they "withheld appropriations from the West." West Virginia's "natural channels" meant that "[o]ur markets, our trade and our travel" occurred with northern and western states, generating "little intercourse" among eastern and western Virginians. Differences in "nature, our commerce, travel, habits, associations, and interests" coupled with eastern Virginians' support for the "fatal doctrine of secession" strengthened Boreman's interpretation that "two peoples" occupied the same state, making the Old Dominion's dismemberment inevitable. $^{1}$

Boreman's memory of Virginia's sectional history reflected the difficulty leading a state still struggling with the issue of slavery. West Virginia's path to statehood was fraught with numerous obstacles and divisive issues, most notably slavery. In 1861, Northwest residents pledged loyalty to the United States for, among other reasons, the government's unwavering commitment to slavery and slaveholding interests. Northwest politicians carried this message to

\footnotetext{
${ }^{1}$ Arthur I. Boreman, “Inaugural Address of Governor Arthur I. Boreman,” West Virginia Archives \& History: West Virginia Division of Culture and History [www.wvculture.org/history/boremania.html][accessed 21 June 2013].
} 
Richmond in 1861, attempting to convince their fellow Virginians that their constituents supported slavery and would protect slaveholders' chattel from meddling abolitionists and a Republican president. Northwesterners' support for easterners' property, though, was contingent upon remaining in the Union, for an alliance with Deep South planters imperiled the political rights guaranteed by the 1851 Constitution. Any disruption of equilibrium between slavery and democracy threatened to destroy both institutions. Despite northwesterners' protestations, Virginia seceded and joined the Confederate States of America.

The commencement of civil war divided Northwest residents. Secessionists' applauded the Richmond convention's decision and promised to defend the state and new nation from northern enemies. Many northwesterners considered secession an unforgivable act and grounds for dismemberment, however, while others stressed caution and deliberation, wary that hasty action would precipitate further calamities or a speedy conclusion to the war would embarrass the movement. Confederate military victories, though, impressed upon the majority of Northwest unionists that dividing Virginia would protect African American bondage and democratic rights. A series of meetings and conventions established a reorganized government for loyal Virginians and laid the groundwork for the statehood movement. But the statehood movement, rather than promoting cohesion and unity, fostered more division and acrimony.

The statehood movement's divisiveness centered on the issue of slavery. Politicians and residents had expressed caution tackling the subject because of the institution's centrality to northwesterners' political thinking. Northwest Republicans emerged as vocal supporters of abolishing slavery to save the Union and to hasten West Virginia's creation. Republicans, aided by the presence of federal troops and their identification with the statehood movement, stressed that slavery's abolition in western Virginia would liberate white residents from the political 
tyranny imposed by eastern Virginia oligarchs. Slavery, the central cause of secession and the Civil War according to Republicans, had severed the remaining bonds of union between eastern and western Virginians; removing this cancer from the body politic represented a lasting rebuke to the Richmond "Slave Power" and those who performed that cabal's bidding in the Northwest. Slavery's destruction in western Virginia would also undermine Confederate efforts, hasten the war's conclusion, and preserve the Union. "Shall we object that slavery is destroyed...if the Union is thereby saved," Boreman questioned. ${ }^{2}$ Republicans' leadership in the new statehood movement increased their popularity, allowing them to control the direction of the state and the memory of its formation.

Republicans' eagerness to abolish slavery encountered intense opposition. Many nonRepublicans who supported the statehood movement suggested measures that prohibited importing African Americans into the state while others insisted that market forces would slowly drain that population southward. Other westerners were more vocal in their opposition. Conservative northwesterners - some who expressed varying degrees of support for statehood while others outright opposed it — worried about the broadening scope of war, notably Republicans' flagrant dismissal and denigration of fundamental constitutional rights. Foremost among these rights were those of slaveholders. "[W]aging...a war for the abolishment of slavery in the southern States is in open violation of the Constitution," the Clarksburg Patriot insisted. ${ }^{3}$ A war to save the Union had evolved into a war to destroy slavery, a development that unconditional unionists before the war had not supported and now strongly opposed. John Carlile maintained this position, arguing that directions from congressional Republicans to create

\footnotetext{
${ }^{2}$ Boreman, "Inaugural Address."

${ }^{3}$ Clarksburg Patriot, April 3, 1863, 2.
} 
a new state amounted to congressional dictation. The creation of West Virginia reflected political submission, conservatives averred, not liberation.

The Union's victory over the Confederacy in 1865 overshadowed conservatives' arguments, a phenomenon that has shaped the memory and historiography of West Virginia's founding. The seemingly inevitable conflict of slaveholding states and nonslaveholding states has colored historians' arguments concerning the inevitable conflict between eastern slaveholders and western nonslaveholders in Virginia. Western nonslaveholders, aware that their political liberation was near, helped overthrow the Richmond "Slave Power," destroy African American bondage, and separate from eastern Virginians. As Charles Ambler argued, these developments in Virginia represented a "microcosm" of the national struggle. ${ }^{4}$ Decades of conflict concerning slaveholders' prerogatives, slavery's political characteristics, geographical isolation, and political inequality led to the creation of West Virginia, William Freehling argues, leaving Virginia "shattered" by $1863 .^{5}$

This argument concerning the inevitable and inexorable conflict between western and eastern Virginians has received broad scholarly support from contemporary and current historians. Theodore Lang averred that during the "thirty years before the Rebellion," a "condition of absolute hostility" existed between eastern and western Virginians. Matters of political inequality, specifically limited suffrage, unequal representation, and unfair taxation, contributed to this "hostility." Further, "in order to secure the suffrage of people of his district," Lang claimed that prospective candidates for political office had to "pledge...t to the principle of a division of the state." Politics in the Northwest, therefore, centered on dismemberment. ${ }^{6}$

\footnotetext{
${ }^{4}$ Ambler, Sectionalism in Virginia, 335.

${ }^{5}$ Freehling, Road to Disunion: Secessionists Triumph, 526.

${ }^{6}$ Lang, Loyal West Virginia, 3-4.
} 
Charles Ambler argued that the creation of West Virginia arose from the Old Dominion's sectional conflict, a development that was "impossible" to prevent. The "radicals of the northwest" succeeded in 1863 in "dismembering the "Mother of Commonwealths," he concluded, a fitting coda to a process decades in the making. ${ }^{7}$ Henry Shanks maintained that the "separate state movement was part of a long, sectional rivalry" that had been building for decades over the political issues raised by Lang and Ambler. Northwesterners' nearly unanimous opposition to secession while eastern Virginians embraced the Confederacy represented the final act in this intrastate sectional struggle. And this struggle not only led to West Virginia's founding but the long-awaited death knell of slavery, too. ${ }^{8}$

Modern historians have generally agreed that Virginia's decades-long sectional struggle culminated in the statehood movement, a movement driven by the same tensions and forces that tore the nation apart in 1861. Daniel Crofts emphasizes that years of "intense" sectional animosity in Virginia generated the "most explosive regional antisecession movement" of the war. Northwesterners, "exploited" and "neglected" by eastern Virginians, argued that the state failed to "provide tangible benefits" for their region while slaveholders enjoyed special privileges. Secession increased sectional tension to a breaking point. ${ }^{9}$ The "formation of West Virginia...represented a culmination of trends evident" in preceding years, specifically in Virginians' disagreement over slavery's role and power in electoral politics, William Link argues. By the 1850s, William Link argues that "West Virginia exceptionalism emerged and blossomed as a social and political phenomenon." Residents, imbued with this ethos, challenged

\footnotetext{
${ }^{7}$ Charles H. Ambler, "The Cleavage between Eastern and Western Virginia," American Historical Review, 15, no. 4 (July 1910): 780.

${ }^{8}$ Shanks, Secession Movement in Virginia, 211-212. Other earlier historians have echoed this interpretation. Granville Davisson Hall, Virgil A. Lewis, and George E. Moore contend that sectional grievances dating back to the American Revolution set in motion the creation of West Virginia, an inevitable result considering eastern Virginians' refusal to embrace democratic reforms and abandon slavery.

${ }^{9}$ Crofts, Reluctant Confederates, 159-160.
} 
eastern slaveholders' hegemony while articulating militant antislavery appeals. The widespread acceptance of antislaveryism provided the contours for West Virginia's establishment as a free state in 1863. Thus, the "same narrative of sectional conflict" that unfolded across the nation during the Civil War era was manifest in Virginia, too. ${ }^{10}$

The statehood movement's culminating phases appears to bear out that interpretation, specifically in regard to abolishing slavery. Northwest Virginia represented what William Freehling considers one of the South's "white belts," areas where geographic features prevented widespread plantation agriculture and large slave populations. With little personal, financial, or political investment in the institution, northwesterners faced little difficulty in resolving the issue of slavery on the path toward statehood. ${ }^{11}$ James Oakes maintains that only western Virginians' "deference to the property rights of slaveholders," not their deep investment in racial hierarchy or defense of slavery, convinced them to initially "block the adoption of a gradual emancipation clause in the new state constitution." ${ }^{12}$ Northwestern Republican organs during the war offered similar arguments concerning slavery's fate in the new state. As a writer in the Wellsburg Herald explained, slavery had placed eastern and western Virginia in its "conflicting position," making it "unjustifiable" and "reprehensible" that northwesterners should further condone that institution. ${ }^{13}$ Residents' eventual and overwhelming support for gradual emancipation in 1863 provided "an unmistakable indication" that northwesterners demanded a free state. ${ }^{14}$

A closer analysis of the statehood movement suggests a more divided constituency and uncertainty surrounding slavery's future in the Northwest and West Virginia. Far from a

\footnotetext{
${ }^{10}$ Link, "“This Bastard New Virginia," 38-40.

${ }^{11}$ Freehling, South vs. the South, 23.

${ }^{12}$ James Oakes, Freedom National: The Destruction of Slavery in the United States, 1861-1865 (New York: W.W. Norton \& Co., 2013), 295.

${ }^{13}$ Wellsburg Herald, September 20, 1861, 2.

${ }^{14}$ Daily Intelligencer, April 22, 1862, 2.
} 
comfortable or clean divorce from the institution, northwesterners experienced a protracted and difficult debate concerning African American bondage. Residents acknowledged slavery’s vital importance to political rights and wondered how to reconstruct white liberty without black bondage. Northwesterners' reluctance to embrace emancipation also reflected their hatred for abolitionists who allegedly desired to foist immediate emancipation and racial equality upon West Virginians. But emancipation on northwesterners' own terms made emancipation more tolerable, a sentiment that increased in popularity as guerrilla conflict continued in the mountains and the Civil War's conclusion appeared uncertain.

The changing war context, though, provided only part of the reason for northwesterners' ratification of gradual emancipation. Following months of intense popular debate, statehood promoters convinced residents that racial hierarchy would survive without slavery, as African Americans would remain subordinate while white residents retained their superior political, social, and economic statuses. An exodus of slaves and freed blacks following statehood would produce a demographic "whitening” of West Virginia, supporters declared, preserving the new state for white residents only. The few remaining freed blacks would labor in menial, service positions, a visual manifestation of the racial hierarchy West Virginians sought to perpetuate. Restrictive laws, including corporal punishment, extended antebellum "justice" on African Americans into the statehood years, too. Though slavery eventually ceased to operate within the Mountain State, the institution's effects lingered. Residents' belief in liberty for whites and slavery for blacks, a stance derived from and animated by residents' deep engagement in the “politics of slavery" over the preceding decades, provided the foundation for West Virginia's establishment. 
The Constitutional Convention convened in Wheeling on November 26, 1861. Critical issues lay ahead for delegates, notably defining the state boundaries, settling on a name for the new state, and, above all, settling the issue of slavery. As John Stealey III has noted, delegates approached resolving these issues through two methods. Some delegates suggested that the 1851 Constitution required only slight modifications while others maintained that eastern Virginians' rebellion required westerners to overhaul that constitution and write a new one. ${ }^{15}$ James H. Brown of Kanawha County and Peter G. Van Winkle from Parkersburg articulated these two positions. Brown, a lawyer and slaveholder, argued that anything "Virginian commends itself to my approval first and foremost." Brown admonished those delegates who considered it "a mark of degradation... [and] opprobrium" to borrow constitutional or political principles "that is Virginian."16 Van Winkle, though, disagreed. "We are here with a blank sheet of paper on which we are to write a constitution," he declared. He opposed Brown's motion "to take the old constitution and patch it here and there." 17 Whether or not these framers would write a new constitution that mirrored Virginia's constitutional history represented a central theme of the convention.

Delegates first tackled the state's boundaries. The secession ordinance ratified by voters in October identified those counties included in the new state, but statehood opponents suggested adding more counties in an effort to foil the movement. On December 3, the Committee on Boundary reported that in addition to the original thirty-nine counties contained in the October

\footnotetext{
${ }^{15}$ Stealey, West Virginia's Civil War-Era Constitution, 74-75.

${ }^{16}$ Debates and Proceedings of the First Constitutional Convention of West Virginia, 20 December 1861 [hereafter cited as Constitutional Convention of West Virginia] [http://www.wvculture.org/history/statehood/cc122061.html] [accessed 14 July 2015]; 1860 U.S. Federal Census: Charleston, Kanawha, Virginia; Roll: M653_1356; Page: 161; Image: 168; Family History Library Film: 805356 [Ancestry.com][accessed 14 July 2015]; and, 1860 U.S. Federal Census - Slave Schedules: Kanawha, Virginia [Ancestry.com][accessed 14 July 2015].

${ }^{17}$ Constitutional Convention of West Virginia, 20 December 1861

[http://www.wvculture.org/history/statehood/cc122061.html] [accessed 14 July 2015]
} 
ordinance, committee members proposed an additional thirty-two counties. ${ }^{18}$ Most of these counties, located in the Shenandoah Valley and southwest, had supported secession and remained under Confederate control. ${ }^{19}$ Committee members defended these new boundaries. Chapman J. Stuart of Doddridge County argued that including these counties shielded unionists there from the "oppression and tyranny of eastern Virginia." Such men endured the same political inequality as northwesterners and deserved protection from a new government. ${ }^{20}$ Brown concurred with Stuart. Echoing a previous argument made by Marion County delegate Ephraim B. Hall, Brown argued that the presence of "one solitary Union man in those counties" should compel the convention to expand the state's boundaries. These unionists deserved our "protection and aid, and we ought to include them and save [them]."21

Other delegates doubted the sincerity of such pronouncements. Ohio County merchant James W. Paxton predicted that this expanded boundary would "embarrass, retard, and...defeat this whole new state project." 22 Fellow Ohio County delegate and Methodist minister Gordon Batelle agreed, characterizing the expanded boundary as "dodge" designed to destroy the

\footnotetext{
${ }^{18}$ Constitutional Convention of West Virginia, 3 December 1861

[http://www.wvculture.org/history/statehood/cc120361.html][accessed 14 July 2015]. Curry notes that whether by design or not, convention president John Hall of Mason County appointed opponents of the statehood movement to the Boundary Committee. Included in this committee was Stuart J. Chapman of Doddridge County, whom Curry characterized as the "most effective obstructionist" in the convention. Curry, House Divided, 87.

${ }^{19}$ Curry, House Divided, 87.

${ }^{20}$ Constitutional Convention of West Virginia, 9 December 1861

[http://www.wvculture.org/history/statehood/cc120961.html][accessed 14 July 2015]

${ }^{21}$ Constitutional Convention of West Virginia, 7 December 1861

[http://www.wvculture.org/history/statehood/cc120761.html][accessed 14 July 2015]. The previous day, Ephraim

B. Hall asked the convention if delegates would "disregard the interests of the loyal people of those counties, because...there are disloyal persons there?" Such a contingency would disqualify practically all northwestern counties, Hall noted. Constitutional Convention of West Virginia, 6 December 1861

[http://www.wvculture.org/history/statehood/cc120661.html][accessed 14 July 2015].

${ }^{22}$ Constitutional Convention of West Virginia, 9 December 1861

[http://www.wvculture.org/history/statehood/cc120961.html][accessed 14 July 2015] and 1860 U.S. Federal Census:

Wheeling Ward 3, Ohio, Virginia; Roll: M653_1368; Page: 174; Image: 182; Family History Library Film: 805368

[Ancestry.com][accessed 14 July 2015].
} 
movement. ${ }^{23}$ Adding a large number of secessionists worried William G. Brown, who quipped that these Confederates could elect a secessionist governor in the new state. ${ }^{24}$ Creating a new state provided western Virginians' an opportunity to break away from the "old slave oligarchy" that ruled the state and declared war against the Union, Cabell County lawyer Granville Parker declared. The Massachusetts-born lawyer suggested that the convention distance themselves from the committee's proposal; if not, "nothing - nothing! - will carry us through" Congress. ${ }^{25}$ Parker's argument concerning the proposed state's affiliation with eastern Virginians reflected some delegates' concern about increasing Kanawha's slave population. Delegates already doubtful of Congress admitting another slave state predicted that increasing the proposed state's slave population would foil statehood. John M. Powell, a minister from Harrison County, remarked that adding more slaves "would destroy us in Congress." 26 Others dismissed such concerns. Waitman Willey considered slavery "doomed," and asserted that "the friends of the institution have brought the doom upon it by their own conduct." He predicted that every slave in the proposed counties would be freed soon through self-emancipation or by the Union army. Adding a few slaves, he concluded, should not prohibit delegates from considering additional counties. $^{27}$

\footnotetext{
${ }^{23}$ Constitutional Convention of West Virginia, 10 December 1861 [http://www.wvculture.org/history/statehood/cc121061.html][accessed 14 July 2015].

${ }^{24}$ Constitutional Convention of West Virginia, 7 December 1861 [http://www.wvculture.org/history/statehood/cc120761.html][accessed 14 July 2015].

${ }^{25}$ Constitutional Convention of West Virginia, 11 December 1861 [http://www.wvculture.org/history/statehood/cc121161.html][accessed 14 July 2015] and 1860 U.S. Federal Census: Guyandotte, Cabell, Virginia; Roll: M653_1338; Page: 61; Image: 67; Family History Library Film: 805338 [Ancestry.com][accessed 14 July 2015].

${ }^{26}$ Constitutional Convention of West Virginia, 10 December 1861

[http://www.wvculture.org/history/statehood/cc121061.html][accessed 14 July 2015] and 1860 U.S. Federal Census: Millford, Harrison, Virginia; Roll: M653_1351; Page: 771; Image: 261; Family History Library Film: 805351 [Ancestry.com][accessed 14 July 2015].

${ }^{27}$ Constitutional Convention of West Virginia, 11 December 1861

[http://www.wvculture.org/history/statehood/cc121161.html][accessed 14 July 2015].
} 
Following ten days of what one observed called a "long and profitless debate" concerning the boundary, delegates opposed to the expanded boundaries defeated the committee's proposal, 28-17. ${ }^{28}$ Delegates added nine southern counties while permitting seven Shenandoah Valley counties to vote on admission. ${ }^{29}$ Solidifying the new state's boundaries reopened discussion of the new state's name. "Kanawha" supporters maintained that creating a new state required a name unaffiliated with its progenitor, especially one that had offered nothing but "oppression" to their western brethren, Daniel Lamb of Wheeling maintained. ${ }^{30}$ "[W]e are...casting off the fetters," Peter Van Winkle exclaimed, and retaining any affiliation with "Virginia" required westerners to "bow the knee to Old Virginia." Any "soubriquet" like "West," "New," or "Little" would continue to "degrade us in comparison with" easterners. ${ }^{31}$

But opponents of "Kanawha" stressed that the state's bitter sectional history should convince delegates to embrace the moniker of "West." "Western Virginia has been made dear to all of us" through years of struggle for "western Virginia rights," Marshall County lawyer Elbert H. Caldwell insisted. "32 "[W]e have fought this fight under the name of West Virginia," Waitman Willey stressed, and adopting "West Virginia" reflected residents" "love of right and of

\footnotetext{
${ }^{28}$ Chester D. Hubbard to William Hubbard, 20 December 1861, Hubbard Family Papers, A\&M 805, WVRHC.

${ }^{29}$ MacKenzie, "Fifth Border State," 191. The nine counties included were Boone, Logan, Mercer, Wyoming, Raleigh, McDowell, Greenbrier, Monroe, and Pocahontas. The Shenandoah Valley counties of Pendleton, Hardy, Hampshire, Morgan, Berkeley, Jefferson, and Frederick voted in favor of joining the new state except the last county. Not all northwestern delegates, though, approved of this measure. Henry Dering, of Morgantown, though he supported including these counties in the new state, believed that this "additional Territory will prove disastrous." He confessed that he voted for the measure because the railroads in these counties "are a Commercial and may be at some future day a Military necessity." Henry Dering to Waitman T. Willey, 13 December 1861, Charles H. Ambler Collection, A\&M 122, Box 10, Folder 7, item 354, WVRHC.

${ }^{30}$ Constitutional Convention of West Virginia, 3 December 1861

[http://www.wvculture.org/history/statehood/statename.html][accessed 14 July 2015].

${ }^{31}{ }^{31}$ Constitutional Convention of West Virginia, 3 December 1861

[http://www.wvculture.org/history/statehood/statename.html][accessed 14 July 2015].

${ }^{32}$ Constitutional Convention of West Virginia, 3 December 1861

[http://www.wvculture.org/history/statehood/cc120361.html][accessed 14 July 2015] and 1860 U.S. Federal Census: Moundsville, Marshall, Virginia; Roll: M653_1360; Page: 195; Image: 201; Family History Library Film: 805360 [Ancestry.com][accessed 14 July 2015].
} 
liberty." ${ }^{33}$ Chapman Stuart believed that the same "fire and patriotism" that previous western Virginians exhibited in defending the state and nation was manifest in "the people of northwestern Virginia." Retaining the name of "Virginia" honored the Revolutionary spirit that continued to animate northwesterners. ${ }^{34}$ Proponents of "West Virginia" carried the day, with a strong majority pulling in favor over "Kanawha" or "Western Virginia." 35

First and Second Wheeling Convention delegate John J. Davis worried that the convention's progress outpaced residents' desires. A "body of radicals and extremists" seized control of the convention, Davis lamented, and threatened to "change in toto the character of our State government." Such men wanted to "give us a Yankee constitution and laws," a prospect that "will defeat the whole movement in West Va." ${ }^{36}$ These "Yankee" sentiments were manifest in debates on the viva voce voting system. Republican Granville Davisson Hall later proclaimed that this "open" voting system perpetuated the "domination of the slave aristocracy." 37 Some delegates arrived at similar conclusions and mentioned the May vote on secession for evidence. Hancock County minister Joseph S. Pomeroy remarked that "if it had not been for the viva voce plan of voting Virginia would never have voted herself out of the Union." 38 The "present mode of voting...give[s] an undue power to men of wealth, influence and position - especially party leaders," Gordon Battelle asserted. ${ }^{39}$ Secessionist merchants in Taylor County reportedly filed

\footnotetext{
${ }^{33}$ Constitutional Convention of West Virginia, 3 December 1861 [http://www.wvculture.org/history/statehood/statename.html][accessed 14 July 2015].

${ }^{34}$ Constitutional Convention of West Virginia, 3 December 1861 [http://www.wvculture.org/history/statehood/cc120361.html][accessed 14 July 2015].

${ }^{35}$ The final vote was 30 in favor of "West Virginia"; 9 for "Kanawha"; 2 each for "Allegheny" and "Western Virginia"; and one for "Augusta."

${ }^{36}$ John J. Davis to Anna Kennedy, 7 December 1861, John J. Davis Family Papers, A\&M 1946, Box 1, folder 2, WVRHC.

${ }^{37}$ Hall, Rending of Virginia, 70. The Daily Intelligencer agreed with Hall's statement. The newspaper considered viva voce "one of those old aristocratic thumb screws of Eastern Virginia, engrafted by her and preserved by her...to prop up her despotic influence." Daily Intelligencer, December 6, 1862, 2.

${ }^{38}$ Constitutional Convention of West Virginia, 5 December 1861 [http://www.wvculture.org/history/statehood/cc120561.html][accessed 14 July 2015].

${ }^{39}$ Constitutional Convention of West Virginia, 5 December 1861
} 
suit against approximately twenty unionists who refused to elect a secessionist delegate to the Richmond Convention. Such were the "evils resulting from viva voce voting," mechanic Harmon Sinsel of Taylor County quipped. ${ }^{40}$

But proponents argued that open voting displayed a man's political independence. "[T]he poor man feels his consequence, self-respect and equality with the highest and richest in the land," James Brown of Kanawha stressed. The "viva voce system tends to encourage a manly independence in the voter, and leads him to prize the privilege of voting more highly." Opponents' attempts to inaugurate a secret ballot threatened to turn these independent men into "cowards and slaves" who "will not dare to come up to the polls like men and speak aloud their preferences." Brown finally appealed to Virginians' fondness for this oral tradition. Oral voting “is a Virginia system, long and dearly cherished by our people." 41 Chapman Stuart agreed with Brown. Stuart failed to "detect any corruption" concerning open voting, but asserted that the "independent character that seems to be stamped and inherent in the principles of Virginia" emanated from viva voce. ${ }^{42}$ Despite claims that viva voce inculcated independence, the convention voted to implement the secret ballot and, in the words of Morgantown merchant Henry Dering, maintain the "security" and "purity of the ballot box." 43

[http://www.wvculture.org/history/statehood/cc120561.html][accessed 14 July 2015].

${ }^{40}$ Constitutional Convention of West Virginia, 5 December 1861

[http://www.wvculture.org/history/statehood/cc120561.html][accessed 14 July 2015] and 1860 U.S. Federal Census: Taylor, Virginia; Roll: M653_1381; Page: 503; Image: 7; Family History Library Film: 805381

[Ancestry.com][accessed 14 July 2015]. Richard Locke Brooks of Upshur County similarly noted that a merchant in his county compelled his debtors to elect the politician he desired. The merchant listened to those in his debt cast ballots for his candidate except for one who had the "fortitude" and he "declare[d] his independent choice." Within ten days, Brooks remarked, the merchant filed suit against that voter. Constitutional Convention of West Virginia, 5 December 1861[http://www.wvculture.org/history/statehood/cc120561.html] [accessed 15 July 2015]

${ }^{41}$ Constitutional Convention of West Virginia, 5 December 1861

[http://www.wvculture.org/history/statehood/cc120561.html][accessed 15 July 2015]

${ }^{42}$ Constitutional Convention of West Virginia, 5 December 1861 [http://www.wvculture.org/history/statehood/cc120561.html][accessed 15 July 2015]

${ }^{43}$ Constitutional Convention of West Virginia, 5 December 1861

[http://www.wvculture.org/history/statehood/cc120561.html][accessed 15 July 2015] 
When the constitutional convention adjourned on December 20, delegates had decided the new state's name, boundary, and method of election. But the "more difficult question of slavery is as yet untouched," Wheeling banker Chester Hubbard observed. Hubbard suggested that the convention's reluctance to tackle African American bondage signaled delegates' realization that the "whole movement for division was premature and can not be accomplished at present." Without a resolution on slavery, the new state movement could not proceed. Some "prefer saying nothing about slavery in the constitution while others are for putting the declaration in the" document. Proponents of the former, like Willey, argued members should "say nothing, [and] do nothing" concerning slavery. Members of the latter, including Gordon Battelle, were "disposed to give the subject an airing." Hubbard suggested that the convention should "indicate our future policy on this question" but offer no firm declarations concerning slavery's future. ${ }^{44}$

Some delegates forced the convention to open this discussion on slavery prior to the December adjournment. On November 30, Boone County minister Robert Hagar introduced two resolutions concerning the institution. The first resolution identified "Negro slavery...[as] the origin and foundation of our national troubles, and the cause of the terrible rebellion in our midst." Hagar considered the institution "detrimental to the interests of free people." These conclusions led him to propose "gradual emancipation" in the second resolution. James Brown of Kanawha characterized any discussion of slavery as "unwise and impolitic," and suggested that the state legislature handle this matter. A majority of delegates shared Brown's opinion and tabled Hagar's resolutions. ${ }^{45}$ Two weeks later, Gordon Battelle introduced a similar gradual

\footnotetext{
${ }^{44}$ Chester Hubbard to William Hubbard, 20 December 1861, Hubbard Family Papers, A\&M 805, WVRHC.

${ }^{45}$ Constitutional Convention of West Virginia, 30 November 1861
} 
emancipation clause but included a prohibition on importing slaves into West Virginia.

Delegates tabled Battelle's motions, too. ${ }^{46}$ These gradual emancipation resolutions worried northwestern delegates. "I am sorry [Battelle] has introduced the subject," Henry Dering lamented. ${ }^{47}$ But after conversing with Peter G. Van Winkle, Dering cheerfully reported that only “a handfull” supported Battelle's plan and that delegates “will not have any trouble in keeping the vexed question out of the Constitution." 48

The march of democratic reform in the convention's first month encouraged free state supporters that slavery would soon be expunged, too. Hagar, Battelle, and the Daily Intelligencer believed that West Virginia's future mirrored that of its free state neighbors. "[W]e can never be a Southern State," the Daily Intelligencer declared. "We may say that we are a Southern State, and that we ought to have a negro policy, just as many foolish people in Western Virginia have said for years past," but such thoughts only "mock, deride, and curse us."49 But such thoughts still remained in the minority, despite Campbell's assertions. Northwestern delegates had long maintained that democratic reform and slavery were compatible, if not symbiotic. Moving toward a secret ballot would not inaugurate slavery's demise or undermine slaveholders' power; other southern states operated with the secret ballot and slavery thrived. ${ }^{50}$ Nor would later actions undertaken by the convention threaten the institution, including

[http://www.wvculture.org/history/statehood/cc113061.html][accessed 15 July 2015] and 1860 U.S. Federal Census: Boone, Virginia; Roll: M653_1336; Page: 2; Image: 6; Family History Library Film: 805336

[Ancestry.com][accessed 15 July 2015].

${ }^{46}$ Constitutional Convention of West Virginia, 14 December 1861

[http://www.wvculture.org/history/statehood/cc121461.html][accessed 15 July 2015].

${ }^{47}$ Henry Dering to Waitman T. Willey, 13 December 1861, Charles H. Ambler Collection, A\&M 122, Box 10, Folder 7, item 354, WVRHC.

${ }^{48}$ Henry Dering to Waitman T. Willey, 16 December 1861, Charles H. Ambler Collection, A\&M 122, Box 10, Folder 7, item 361, WVRHC.

${ }^{49}$ Daily Intelligencer, December 9, 1861, 2.

${ }^{50}$ Stealey, West Virginia's Civil War-Era Constitution, 81. Only Virginia, Kentucky, Georgia, and Oregon used the viva voce voting system, with the latter two providing power to state legislatures to use the ballot system. Constitutional Convention of West Virginia, 5 December 1861

[http://www.wvculture.org/history/statehood/cc120561.html][accessed 15 July 2015]. 
replacing the county court system with townships or instituting ad valorem taxation or creating a system of free public schools. ${ }^{51}$ Northwesterners had long supported these initiatives and dismissed concerns that democratic reforms would disturb the master-slave relationship. Rather, these reforms would strengthen white equality and marginalize criticism of slavery and slaveholders.

That gradual emancipation supporters faced a hostile audience, then, should not be surprising. Cabell County delegate Granville Parker later remarked that the institution held a "mysterious and over-powering influence" that became manifest when Battelle introduced his resolutions. ${ }^{52}$ The “influence" Parker observed represented slavery's continued centrality to political matters, and that delegates' constituents remained reluctant to abandon African American bondage even as the Civil War continued. This "influence" also reflected residents' hatred of abolitionism. As the Clarksburg National Telegraph averred, "fanatical abolitionists" like Battelle who advocated emancipation "cling to the ebony, woolly-headed god of their idolatry." Battelle should labor for the "preservation of the liberties of the twenty millions of white people who are fighting to retain their free institutions than to be wasting time in endeavoring to liberate the few thousand slaves of West Virginia." Further, if Battelle and his ilk succeeded in foisting emancipation upon West Virginians, what other legislation would they enact? Would they seek racial equality at the ballot box $?^{53}$ Unless free state advocates could ensure the perpetuation of racial hierarchy without slavery, West Virginia's prospects as a free state appeared fleeting.

\footnotetext{
${ }^{51}$ For an overview of these constitutional changes, see Stealey, West Virginia's Civil War-Era Constitution, 83-94.

${ }^{52}$ Granville Parker, The Formation of the State of West Virginia: and other incidents of the late Civil War, with remarks on subjects of public interest, arising since the war closed (Wellsburg, WV: Glass \& Son, 1875 ), 78.

${ }^{53}$ National Telegraph, February 7, 1862, 2.
} 
The constitutional convention reconvened in early January 1862 following a brief recess. Gordon Battelle introduced similar resolutions on slavery, including a colonization plan and pushing back gradual emancipation until July 4, 1865. Delegates tabled those resolutions. ${ }^{54}$ Henry Dering chastised Battelle for "press[ing] this subject upon us," and feared that further agitation on slavery "will prove the opening of Pandoras Box." 55 Dering further admonished Battelle for such resolutions, insisting that these actions would "prove...fatal before the people." Battelle and his ilk "will not be able to carry his proposition," Dering predicted but feared that this constant agitation would "produce disturbance[s]" in West Virginia and other Union slave states. ${ }^{56}$ The Wellsburg Herald agreed with Dering's conclusion. "The people will not vote for gradual emancipation or any other interference with the rights of slave owners." Many delegates will "snap and snarl" if Battelle continued to persist in his antislavery mission, jeopardizing the entire movement. ${ }^{57}$

Battelle persisted despite these fatalistic predictions. On February 12, he introduced a set of similar resolutions. Battelle supported a prohibition on African Americans entering the state after the constitution's ratification and paired this with a more lenient gradual emancipation clause. West Virginia voters, not constitutional delegates, would either ratify or reject these resolutions. ${ }^{58}$ Battelle demanded an open and candid discussion on slavery, quipping that he "hope[d] that no such gag rule will be instituted here in this Convention." 59 Chapman Stuart

\footnotetext{
${ }^{54}$ Constitutional Convention of West Virginia, 27 January 1862 [http://www.wvculture.org/history/statehood/cc012762.html] [accessed 15 July 2015].

${ }^{55}$ Henry Dering to Waitman T. Willey, 28 January 1862, Charles H. Ambler Collection, A\&M 122, Box 10, Folder 7, item 374, WVRHC.

${ }^{56}$ Henry Dering to Waitman T. Willey, 5 February 1862, quoted in Curry, House Divided, 91.

${ }^{57}$ Wellsburg Herald, January 31, 1862, 2.

${ }^{58}$ Battelle proposed to emancipate slaves born after 1870 after males reached twenty-eight years and females eighteen years of age. These changes meant that slavery would continue to exist well into the twentieth century.

${ }^{59}$ Battelle purposely referenced the "gag rule" to parallel the experiences of antislavery West Virginians with those of antislavery northerners who had their speech limited by proslavery advocates decades earlier. In 1836, the U.S. House of Representatives enacted a "gag rule" whereby abolition petitions sent by the American Anti-Slavery
} 
chided Battelle, declaring that the issue of slavery was "not debatable." Delegates tabled these resolutions, too, 24-23. ${ }^{60}$ The following day, Hancock County minister Joseph Pomeroy suggested a compromise. West Virginians "do not want free negroes here," Pomeroy declared, leading him to recommend the adoption of Battelle's prohibition on African Americans entering the state following the constitution's ratification. By a 48-1 margin, delegates adopted Battelle's motion. Following the vote, Marion County delegate Hiram Raymond instructed Battelle to "never mention slavery here again." 61

The convention adjourned a few days later after formally adopting a new state constitution. Despite dire warnings from proslavery advocates that "a body of radicals and antislavery sympathisers" would inaugurate a "Yankee constitution," the final draft of the constitution demonstrated that West Virginians "were also Virginians." ${ }^{22}$ This Virginia mindset was manifest in how delegates resolved the issue of slavery. Battelle's resolution prohibiting the importation of any African Americans, free or enslaved, amounted to a disappointing defeat for "free soil" advocates. An anonymous Tyler County resident derisively referred to it as "our proslavery Constitution" and doubted that Congress would approve this constitution. ${ }^{63}$ The Wellsburg Herald, though, acknowledged the difficulty in introducing Battelle's prohibition measure. A "direct emancipation clause...would have shocked long-existing prejudices of a majority of the people," the newspaper reasoned. Aggressive advocates of emancipation "make a great noise, [but] in numbers they don't amount to much outside of the Panhandle." The

\footnotetext{
Society would not be debated by delegates but referred to a House committee. Wilentz, Rise of American Democracy, 451-452.

${ }^{60}$ Constitutional Convention of West Virginia, 12 February 1862 [http://www.wvculture.org/history/statehood/cc021262.html][accessed 16 July 2015].

${ }^{61}$ Constitutional Convention of West Virginia, 13 February 1862 [http://www.wvculture.org/history/statehood/cc021362.html][accessed 16 July 2015].

62 John J. Davis to Anna Kennedy, 10 February 1862, John J. Davis Family Papers, A\&M 1946, Box 1, Folder 3, WVRHC.

${ }^{63}$ Daily Intelligencer, March 8, 1862, 1.
} 
"people," it concluded, "are not yet ripe for that question." 64 Though some Republicans and free state supporters hoped that West Virginia's climate and lack of southern staples would compel African Americans to move to warmer climates, natural reproduction would likely ensure slavery's presence in the new state. ${ }^{65}$ Many West Virginians "seem to rely with implicit confidence upon the silent innovations of future years for [slavery's] elimination from our midst," an unnamed resident remarked. "The voice of history is a disappointment to their cherished hopes." 66 For free state promoters, Battelle's resolution failed to resolve the slavery question.

But for some West Virginia politicians and residents, Battelle's resolution amounted to a compromise that saved the statehood movement. Henry Dering predicted that had the convention adopted all three of Battelle's resolutions, "the whole...Sou[th] Western Delegation would have left... and have got their whole people to oppose it." The new constitution "would have been voted down by the Counties from Harrison [County] to the Kentucky line."67 Dering later reported that the convention's ratification of all three of Battelle's resolutions would have "kill[ed] the new state" in the Kanawha River Valley. ${ }^{68}$ Taylor County farmer William W. Warder maintained that delegates constructed "a firstrate constitution" and had "settled the niger

\footnotetext{
${ }^{64}$ Wellsburg Herald, March 14, 1862, 2.

${ }^{65}$ Defenders of slavery often argued that African American biological makeup permitted them to work in the South's warm climate, while white men and women lacked this biological composition. Proslavery writers and theorists used this interpretation to justify slave labor and defend slavery from antislavery commentators and abolitionists in the North. Conevery Bolton Valencius, The Health of the County: How Americans Understood Themselves and Their Land (New York: Basic Books, 2002), 238-240. Some West Virginians articulated similar arguments. One anonymous Preston County author stated that slavery "may well exist in the Tobacco, Hemp, Cotton, Rice and Sugar growing portions of our country, where the labour of the black race can be profitably employed and the slave better clothed, fed, and cared for....My desire for a free State arise out of the conviction that our climate and soil... are vastly better adapted to free than salve labour." Daily Intelligencer, February 26, $1862,1$. ${ }^{66}$ Wellsburg Herald, March 28, 1862, 1.

${ }^{67}$ Henry Dering to Waitman T. Willey, 3 March 1862, Charles H. Ambler Collection, A\&M 122, Box 11, Folder 1, item 381, WVRHC.

${ }^{68}$ Henry Dering to Waitman T. Willey, 18 June 1862, Charles H. Ambler Collection, A\&M 122, Box 11, Folder 2, item 414, WVRHC.
} 
question without any excitement." He predicted that the compromise "will be received by all parties with sadisfaction." ${ }^{99}$ A Preston County resident believed that the new constitution would receive the "suffrage of every friend of a New State, whatever may be his proclivities in regard to the colored race."70 Chester Hubbard applauded the "compromise" enacted by the convention, as African Americans would either "flourish or perish as the case may be."71 The Wellsburg Herald agreed with Hubbard's conclusion. The new constitution would "not interfere with the master's rights" but simply allowed slavery to either "stand" or "fall."72

West Virginia Republicans and other free state supporters applauded the "onward spirit and progressive tendencies" of the new constitution's democratic reforms but loathed the convention's refusal to make the new state a free state. ${ }^{73}$ A Hancock County writer characterized the "compromise" on slavery as a "subterfuge" to deceive the public. Virginians had exported, not imported, slaves for decades and slavery continued to expand; how would this measure hasten the institution's extinction in West Virginia? ${ }^{74}$ In a mass meeting in Upshur County, residents maintained that the "interests of the white laboring population" opposed the "peculiar course of legislation" that the "protection of slavery" demands. Those West Virginians who "love slavery...that they cannot consent to have it ever removed are no friends of a new State," gatherers concluded. ${ }^{75}$

Supporters of a free West Virginia denounced their neighbors' attempts to brand Battelle's resolution as an "abolitionist scheme.” One Monongalia County writer admonished

\footnotetext{
${ }^{69}$ William W. Warder to Evy Warder, 13 February 1862, William Wesley Warder Papers, A\&M 1633, WVRHC and 1860 U.S. Federal Census: Taylor, Virginia; Roll: M653_1381; Page: 656; Image: 164; Family History Library Film: 805381 [Ancestry.com][accessed 7 August 2015].

${ }^{70}$ Daily Intelligencer, March 15, 1862, 2. [emphasis in original]

${ }^{71}$ Chester Hubbard to William Hubbard, 13 February 1862, Hubbard Family Papers, A\&M 805, WVRHC.

${ }^{72}$ Wellsburg Herald, February 28, 1862, 2.

${ }^{73}$ Daily Intelligencer, February 21, 1862, 2.

${ }^{74}$ Daily Intelligencer, February 27, 1862, 2.

${ }^{75}$ Daily Intelligencer, March 24, 1862, 2.
} 
constitutional convention delegates who had been "gulled and bamboozled by...advocates and representatives of the small 'nigger interest' in Western Virginia." These delegates had "shrunk... at the old cry of 'abolitionism' sounded by those who own a part of the little stock of niggers now in the west."76 The constitutional convention's refusal to allow public ratification on Battelle's resolutions reminded Brooke County residents of the "Lecompton stratagem" that proslavery politicians in Kansas inaugurated in the 1850s. West Virginia politicians beholden to the institution rejected voters' opinion on slavery because they feared residents' antislavery sentiments. ${ }^{77}$ Republicans lamented that the "old standard slang about 'abolition' has been poured out day by day to serve a personal and partisan purpose.”78 Despite Republicans' protestations, the "abolitionist" shibboleth still commanded tremendous power and influence across West Virginia.

On April 3, West Virginia voters approved the new constitution by a wide margin, 18,862 in favor to 514 opposed. In some precincts, residents could also vote on a nonbinding gradual emancipation clause. As with the new constitution, West Virginians overwhelmingly supported gradual emancipation, 6,052 to $616 .^{79}$ The gradual emancipation proposal mirrored that offered by Battelle, as slaves born after 1870 would be freed upon reaching twenty-eight years for males and eighteen years of age for females. Slaves would continue to reside in the region well into the

\footnotetext{
${ }^{76}$ Daily Intelligencer, March 7, 1862, 1.

${ }^{77}$ Daily Intelligencer, March 7, 1862, 2.

${ }^{78}$ Daily Intelligencer, April 2, 1862, 2.

${ }^{79}$ Curry, House Divided, 97. As Scott MacKenzie argues, though, wartime voting often produced skewed results while lopsided margins in many northwestern counties suggest that free state advocates employed coercive techniques to intimidate opponents or convince them to change their vote. MacKenzie, "Fifth Border State," 196. Despite the overwhelmingly margin in favor of gradual emancipation, some northwestern counties posted significant votes against the measure. In Monongalia, 185 voted against the clause, while 43 opposed it in Brooke County. In Hancock, 44 residents voted against it while 71 in Marshall also voted in the negative. In Ohio County, 54 opposed the measure. Though the vote in favor of gradual emancipation dwarfed those of their opponents, the continued presence of an electorate opposed to gradual emancipation reveals a contested political battleground and a measure of dissent that would continually contest measures against slavery. Daily Intelligencer, April 23, 1862, 2.
} 
twentieth-century. Free state supporters believed that this informal election provided "an unmistakable indication that our people want to make their State a free State." 80 The Wellsburg Herald declared the informal poll on gradual emancipation "a blow at slavery, and...[it] cripples the rebellion more than the defeat of an army." 81 Others were less sanguine, however. Peter G. Van Winkle considered the "grand experiment of taking a vote on emancipation at the late election... a fizzle" that had frustrated free state supporters. ${ }^{82}$ John G. Jacob inferred that strong support for gradual emancipation reflected residents' desire to control possible emancipation without congressional interference, not a reflection of West Virginians' antislaveryism. ${ }^{83}$

Historians have generally interpreted the informal poll on the gradual emancipation clause as revealing West Virginians' desire to liberate their region from slavery's deleterious effects. Granville Davisson Hall proclaimed that the vote demonstrated that West Virginians "were ready to accept emancipation — eager to do so — as giving their new State its fitting status at home." ${ }^{84}$ Richard Curry declared the vote a "turning point in the history of statehood politics," igniting residents' latent and long-held antislavery sentiment. ${ }^{85}$ For some West Virginians, the vote on the gradual emancipation represented their opportunity to destroy the institution that had instigated the war and torn asunder the Union. These residents also blamed slaveholders who prized their chattel over white political equality for the constitutional ills that had plagued the Northwest over the preceding decades. "The wicked rebellion, as well as all the past and present injustices suffered by Western Virginia," Upshur County resident William M.

\footnotetext{
${ }^{80}$ Daily Intelligencer, April 22, 1862, 2.

${ }^{81}$ Wellsburg Herald, April 25, 1862, 2.

82 Peter G. Van Winkle to Waitman T. Willey, 10 June 1862, Charles H. Ambler Collection, A\&M 122, Box 11, Folder 1, item 411, WVRHC.

${ }^{83}$ Wellsburg Herald, April 25, 1862, 2.

${ }^{84}$ Hall, Rending of Virginia, 507. For a similar interpretation, see Foulds, "Enemies of the State," 297-298.

${ }^{85}$ Curry, House Divided, 97.
} 
Shinn declared, "are due to Slavery and the evil principles engendered by it." ${ }^{86}$ Residents" vote on April 3 confirmed their resolve to hasten slavery's demise, the source of the political and economic inequality that had plagued their region for decades. As Preston County merchant Harrison Hagans maintained, the "masses were sincere" in their vote, believing that a "New State meant not only loyalty, but prospective deliverance from slavery." 87

For other West Virginians, the informal poll represented their opportunity to take control of the statehood movement from misguided delegates. Disappointed that delegates during the constitutional convention had capitulated to slaveholding interests, these residents would use the ballot box to admonish their representatives and manifest their desires concerning slavery. Lewis County physician Newton B. Barns reported that the "great masses fully expected the convention to propose the new state freed of slavery." Residents reacted with "surprise... and regret" that the convention included only Battelle's prohibition measure. ${ }^{88}$ Residents understood that their petition to Congress for admission would be stronger if the state sought entry as a free state, not a slave state, a move that reflected political pragmatism rather than deeply-held emancipationist sentiments. As a Ritchie County resident argued, the "road by which slave States have traveled into the Union, has become so slippery with the blood of the brave men of our nation that it cannot be traveled any more." The war had made slavery unpalatable and West Virginia's admission as a slave state unfeasible. Placing slavery on a path toward gradual extinction would ensure the state's admission to the Union. ${ }^{89}$

\footnotetext{
${ }^{86}$ William M. Shinn to Waitman T. Willey, 14 July 1861, Charles H. Ambler Collection, A\&M 122, Box 10, Folder 7, item 335, WVRHC. [emphasis in original]

${ }^{87}$ Harrison Hagans to Waitman T. Willey, 2 May 1862, Charles H. Ambler Collection, A\&M 122, Box 11, Folder 1, item 400, WVRHC and 1860 U.S. Federal Census: Brandonville, Preston, Virginia; Roll: M653_1372; Page: 2; Image: 6; Family History Library Film: 805372 [Ancestry.com][accessed 21 July 2015].

${ }^{88}$ Newton B. Barns to Waitman T. Willey, 21 February 1862, Charles H. Ambler Collection, A\&M 122, Box 11, Folder 1, item 377, WVRHC and 1860 U.S. Federal Census: Lewis, Virginia; Roll: M653_1358; Page: 50; Image: 56; Family History Library Film: 805358 [Ancestry.com][accessed 21 July 2015]. [emphasis in original]

${ }^{89}$ Daily Intelligencer, March 5, 1862, 1.
} 
Other West Virginians wanted to control the statehood movement because they feared congressional interference and abolitionist meddling. As Arthur I. Boreman reported, "many good men in Wheeling, who generally took no part in politics, were opposed to congress prescribing the provisions of our constitution on any subject embraced in it." This fear of “congressional dictation" received widespread support from John Carlile. ${ }^{90}$ Carlile and other conservatives feared that the war and demands for unquestioned patriotism provided a "pretext for transcending Constitutional limits," notably private property rights. ${ }^{91}$ As the Republican Wellsburg Herald explained in its defense of the Union army confiscating slaves, the "present emergency" necessitated such actions to prevent Confederates from exploiting slaves’ “intelligence" and "military aid."92 Such arguments smacked of congressional tyranny, according to some conservatives. "Congress has no right to go further and inquire into the domestic institutions of the state," the National Telegraph maintained. "The people of the State themselves must be left free to regulate their own domestic affairs," the newspaper stressed. The prospect of "Congressional dictation" took on added urgency as the "negro loving fanatics in Congress" appeared bent on making West Virginia a free state without "the people determin[ing] the question for themselves in in their own way."93

West Virginians' fear of "Congressional dictation" reflected their hatred for abolitionists. Abolitionists' advocacy of racial and political equality threatened the hierarchies that residents had championed and defended over the preceding decades. Recent actions by the federal government concerning slavery augmented those fears. In March 1862, Waitman Willey

\footnotetext{
${ }^{90}$ Arthur I. Boreman to Francis H. Pierpont, 30 July 1862, Francis Harrison Pierpont Papers, A\&M 9, Box 3, Folder 3, WVRHC.

${ }^{91}$ National Telegraph, May 9, 1862, 2.

92 Wellsburg Herald, June 27, 1862, 2.

${ }^{93}$ National Telegraph, June 13, 1862, 2. [emphasis in original]
} 
denounced the bill to abolish slavery in the District of Columbia in March 1862, castigating the legislation as neither "essential, nor even beneficial, in prosecuting the war and restoring the peace." Willey further doubted that emancipating slaves would change African American's status in the body politic. "You may emancipate the slave, and call him free," he affirmed, "but he is still a slave. He can never be anything else in this country." Abolitionists' attempts to turn African American slaves into "freemen...is utterly fallacious," he insisted. ${ }^{94}$ Morgantown merchant Henry Dering agreed with Willey. The "whole series of Nigger bills which are being introduced into Congress are all wrong, untimely and calculated to do mischief," he declared, "and the abolition of slavery in the district...is exceedingly unfortunate." 95 Congress should "leave [slavery] to Providence and our people to work out," he concluded. ${ }^{96}$

Residents' informal ratification of gradual emancipation also signaled their attempt to limit the power wielded by West Virginia Republicans, a group that often appeared allied with northern abolitionists. Chester Hubbard reported that "Republicanism has full sway in the Panhandle," and that Republicans "are making every thing bend to the behest of party."97 The Wheeling Daily Intelligencer's stance on gradual emancipation in connection with statehood "has been jesuitical," Van Winkle grumbled. Newspaper editor Archibald Campbell and his ilk opposed the "New State unless the Abolitionists can rule," what Van Winkle considered a "humiliating condition." 98 He later prayed that this Republican "clique will be able to lay the

\footnotetext{
${ }^{94}$ Waitman T. Willey, Speech of W.T. Willey of Virginia, on the Abolition of Slavery in the District of Columbia, Delivered in the United States Senate, March 20, 1862 (Washington, D.C.: Towers, Printers, 1862), 5, 8. ${ }^{95}$ Henry Dering to Waitman T. Willey, 29 April, 1862, Charles H. Ambler Collection, A\&M 122, Box 11, Folder 1, item 399, WVRHC. [emphasis in original]

${ }^{96}$ Henry Dering to Waitman T. Willey, 18 June 1862, Charles H. Ambler Collection, A\&M 122, Box 11, Folder 2, item 414, WVRHC.

${ }^{97}$ Chester Hubbard to William Hubbard, 26 September 1861, Hubbard Family Papers, A\&M 805, WVRHC.

${ }^{98}$ Peter G. Van Winkle to Waitman T. Willey, 10 June 1862, Charles H. Ambler Collection, A\&M 122, Box 11, Folder 1, item 411, WVRHC.
} 
devil [of emancipation] they have raised." 99 John J. Davis, disgusted with the "Anti-Slavery parasites" in the state legislature who attempted to foist emancipation on West Virginians, voted against an antislavery measure. ${ }^{100}$ He later predicted that the Daily Intelligencer would provide "Comments" on this negative vote and that the newspaper along with other Republicans would encourage his constituents to convene "another indignation meeting" against him. By determining how West Virginians would control and resolve the issue of slavery, Davis and others believed that they could remove such "parasites" from the body politic before they infected it with radical ideas. ${ }^{101}$

Residents' aspiration for a new state deepened in mid-1862 as Major-General George B. McClellan's Peninsula Campaign appeared poised to capture Richmond and end the war before an independent West Virginia had been secured. Indeed, Governor Francis Pierpont, confident that the "rebellion" would "shortly [be] put down," contacted President Lincoln inquiring about treatment of former Confederates and their political status in the Reorganized Government of Virginia. ${ }^{102}$ Other West Virginians shared this same expectation throughout early 1862 . "We are watching and waiting with anxious hearts for the fall of Richmond," Morgantown attorney J. Marshall Hagans reported. ${ }^{103}$ Residents' anxiousness, though, coexisted with trepidation of reuniting with Confederates. "Wo be to the West," Rev. James L. Clark warned, "if we have to go back under the dominion of Richmond." 104 If Richmond fell and Virginia remained

\footnotetext{
${ }^{99}$ Peter G. Van Winkle to Waitman T. Willey, 27 June 1862, Charles H. Ambler Collection, A\&M 122, Box 11, Folder 2, item 422, WVRHC.

${ }^{100}$ John J. Davis to Anna Kennedy, 11 May 1862, reprinted in Ham, "The Mind of a Copperhead," 105.

${ }^{101}$ John J. Davis to Anna Kennedy, 19 May 1862, reprinted in Ham, "The Mind of a Copperhead," 105-106.

${ }^{102}$ Francis Pierpont to Abraham Lincoln, 14 March 1862, Francis Harrison Pierpont Letters to Abraham Lincoln, A\&M 1034, WVRHC.

${ }^{103}$ J. Marshall Hagans to Waitman T. Willey, 21 June 1862, Charles H. Ambler Collection, A\&M 122, Box 11, Folder 2, item 419, WVRHC and 1860 U.S. Federal Census: District 2, Monongalia, Virginia; Roll: M653_1364; Page: 74; Image: 84; Family History Library Film: 805364 [Ancestry.com][accessed 23 July 2015].

${ }^{104}$ James L. Clark to Waitman T. Willey, 28 June 1862, Charles H. Ambler Collection, A\&M 122, Box 11, Folder 2 , item 426, WVRHC.
} 
undivided, Harrison Hagans of Preston County explained, the "rebel constituency in the East will...send men to represent them, who will tax the West to pay this rebel war debt, and rule it with an iron rod." The "pitiless storm of wrath" that westerners had endured over the preceding decades would be "made hotter by disappointed ambition in this wicked rebellion."105 Unable to create a national "cotton oligarchy," one Clarksburg newspaper predicted that these embittered Confederates would establish a similar "aristocratic structure" in Virginia where the "wealthy" controlled the government and diminished "the influence of the poor man." 106 West Virginians, faced with possible reunion with secessionist Virginians, prayed that a new state would deliver them from their former brethren.

On May 6, 1862, Francis Pierpont convened the General Assembly of the Reorganized Government of Virginia in Wheeling to satisfy constitutional requirements concerning the establishment of a new state. In his address to the legislature, Pierpont stressed that Virginia's "history, geography, and social relation[s]" required dismemberment. Burdensome taxation, unequal representation, and easterners' preference of slave labor over westerners' "free labor" had generated conflict over the preceding decades. The rebellion's possible conclusion threatened to reunite West Virginians with easterners, a prospect many residents loathed. West Virginians needed a new state. ${ }^{107}$ One week later, the legislature granted permission. ${ }^{108}$ On May 29, Senator Waitman Willey presented West Virginia's petition for admission to the Senate, recapitulating the events of the previous two years and the difficult position West Virginia

\footnotetext{
${ }^{105}$ Harrison Hagans to Waitman T. Willey, 2 May 1862, Charles H. Ambler Collection, A\&M 122, Box 11, Folder 1, item 400, WVRHC.

${ }^{106}$ National Telegraph, May 9, 1862, 2 and June 13, 1862, 2.

107 "Governor Pierpont's Address to the Reorganized Government of Virginia, 6 May 1862," A State of Convenience: The Creation of West Virginia, West Virginia Archives \& History [http://www.wvculture.org/history/statehood/pierpont050662.html][accessed 23 July 2015].

108 "Act of the Reorganized Government of Virginia Granting Permission for Creation of New State," A State of Convenience: The Creation of West Virginia, West Virginia Archives \& History

[http://www.wvculture.org/history/statehood/rgov051362.html][accessed 23 July 2015].
} 
unionists occupied during the war. The "loyal spirit of the people of northwest Virginia," he declared, "revolted" against secession and adhered to the Union. "Public mass meetings" held across the Northwest announced "our allegiance to the United States" and sought how to "protect ourselves from the remorseless despotism of the usurpers." 109 Willey, like Pierpont, insisted that Virginia's diverse geographic, commercial, and social institutions produced two civilizations possessing "interests fundamentally different" from the other. ${ }^{110}$ West Virginia's marginal and declining slave population manifested residents' "free labor" interests while the proposed state's climate and geographic proximity demonstrated that "slave labor cannot be profitable there." Armed with evidence of slavery's inevitable extinction in West Virginia, Willey assured northern Republicans that the Mountain State would be a slave state in name only. ${ }^{111}$

The Senate Committee on Territories received Willey's petition and committee chairman Benjamin Wade of Ohio instructed Virginia Senator John Carlile to compose West Virginia's statehood bill. The bill the committee returned on June 23 shocked and disappointed West Virginians. Carlile, in his effort to adhere to strict constitutionalist grounds and defeat the statehood measure, altered Willey's petition. He increased West Virginia by adding fifteen counties and included a gradual emancipation clause that a new constitutional convention would have to ratify. The emancipation clause mandated that all slaves born on or after July 4, 1863, would be free. ${ }^{112}$ Carlile's political chicanery appeared to doom the statehood movement. "The bill carries death to our new state," Henry Dering lamented. The slave population included in the

\footnotetext{
${ }^{109}$ Waitman T. Willey, Speech of Hon. W.T. Willey, Delivered in the United States Senate, May 29, 1862, On Presenting the Memorial of the Legislature of Virginia, requesting the consent of Congress to the erection of a new state within the jurisdiction of that State, to be called “West Virginia," (Washington, D.C.: Scammell \& Co., 1862), 2.

${ }^{110}$ Willey, Memorial of the Legislature of Virginia, 10-12.

${ }^{111}$ Willey, Memorial of the Legislature of Virginia, 13.

112 The fifteen counties included in Carlile's amended bill were Berkeley, Jefferson, Clark, Frederick, Warren, Page, Shenandoah, Rockingham, Augusta, Highland, Bath, Rockbridge, Botetourt, Craig, and Alleghany.
} 
additional fifteen counties would rankle northern Republicans while the entire bill "ignores the action of our loyall people in West Va." Many West Virginians now expected Congress to deny admission. "Our people are in despair and many have now given up all hopes of a new state."113 Methodist Episcopal minister Moses Tichenell of Marion County implored Willey to remove the additional counties from the statehood bill. Shenandoah Valley residents possessed "sympathies, habits, and...interests" identical to those of the "strong niggerdum of the east" and antagonistic to West Virginians. Though his neighbors "are not Abolitionists in the present acceptation of the offensive term," they despised the "rule of southern slave[ry]" and sought freedom from the "tyranical lash of the proud nabobs of eastern Virginia" at any cost. ${ }^{114}$ Morgantown resident J. Marshall Hagans agreed. Though the "vox populi" of West Virginia had not placed their official "stamp" on a gradual emancipation clause, he believed residents would approve that plan if Congress granted admission. ${ }^{115}$

Carlile's political subterfuge elicited censure from many West Virginians who viewed his actions as a denial of majoritarian power. In a meeting in Wetzel County, residents labeled Carlile a "political desperado," a “disgrace," and a “w[i]llful deceiver of his constituents." He acted as one of Jefferson Davis' "minions," truckling to West Virginia Confederates who wished to join the Confederacy and wage war against the Union. ${ }^{116}$ Residents in Taylor County agreed, denouncing their senator for "willfully misrepresent[ing] the loyal people of West Virginia." Carlile must resign lest he continue ignoring and misrepresenting voters. ${ }^{117}$ Though Carlile's

\footnotetext{
${ }^{113}$ Henry Dering to Waitman T. Willey, 27 June 1862, Charles H. Ambler Collection, A\&M 122, Box 11, Folder 2, item 425, WVRHC.

${ }^{114}$ Moses Tichenell to Waitman T. Willey, 28 June 1862, Charles H. Ambler Collection, A\&M 122, Box 11, Folder 2, item 429, WVRHC and 1860 U.S. Federal Census: Triadelphia, Ohio, Virginia; Roll: M653_1368; Page: 493; Image: 505; Family History Library Film: 805368 [Ancestry.com][accessed 24 July 2015].

115 J. Marshall Hagans to Waitman T. Willey, 28 June 1862, Charles H. Ambler Collection, A\&M 122, Box 11, Folder 2, item 428, WVRHC.

${ }^{116}$ Daily Intelligencer, August 12, 1862, 1.

${ }^{117}$ Daily Intelligencer, July 29, 1862, 2.
} 
mouthpiece, the Clarksburg National Telegraph, declared him a "true and loyal statesman" who had "been assiduous in his works of loyalty and for the good of West Virginia," few residents agreed. ${ }^{118}$

Senate debate on West Virginia's admission focused on the issue of slavery. Republican Charles Sumner of Massachusetts, a prominent abolitionist, opposed the gradual emancipation clause as it "recognize[d] the existence of slavery during the present generation." One extra day was "too long for slavery," he announced. He proposed adding a clause that would free all slaves on July 4, 1863. ${ }^{119}$ Willey, though, doubted the efficacy of Sumner's proposal. Providence had ordained that West Virginia "must...be free forever," and his work was already unfolding in the state. West Virginia's climate, soil, geographic position, and declining slave population demonstrated the institution's fleeting prospects. ${ }^{120}$ Political complications, however, would arise with congressional emancipation. Willey acknowledged that a "very considerable amount of secession sentiment" existed in the proposed state, and that these secessionists would wield the issue of slavery to "stir up the prejudices of the people" and "defeat" the statehood movement. Though he preferred senators abstain from interfering with slavery in West Virginia, Willey recognized that abolitionists and northern Republicans would never consent to another slave state. Confronted with this dilemma, Willey sought compromise. ${ }^{121}$

Willey proposed emancipating all slaves born after July 4, 1873, a measure that rankled antislavery northerners and abolitionists. He then introduced a similar measure written by Representative William G. Brown of Preston County that would free slaves born after July 4,

\footnotetext{
${ }^{118}$ National Telegraph, June 27, 1862, 2.

119 "U.S. Senate Debate on West Virginia Statehood, June 26, 1862," A State of Convenience: The Creation of West Virginia [http://www.wvculture.org/history/statehood/ussenatedebate062662.html][accessed 24 July 2015].

120 "U.S. Senate Debate on West Virginia Statehood, July 1, 1862," A State of Convenience: The Creation of West Virginia [http://www.wvculture.org/history/statehood/ussenatedebate070162.html][accessed 24 July 2015 ].

121 "U.S. Senate Debate on West Virginia Statehood, July 14, 1862," A State of Convenience: The Creation of West Virginia [http://www.wvculture.org/history/statehood/ussenatedebate071462a.html][accessed 26 July 2015$].$
} 
1864 and banned future importation of slaves into the state. With assistance from Kansas

Senator James Henry Lane, Willey amended his proposal to include a more comprehensive gradual emancipation policy. The "Willey Amendment" would free slaves born after July 4, 1863, while those younger than ten would be liberated upon turning twenty-one; slaves older than ten but younger than twenty-one would remain enslaved until they reached twenty-five. The "Willey Amendment" also contained a ban on importing African American slaves into the state. Senators approved the compromise and West Virginia's admission by a 23-17 vote. ${ }^{122}$ When the House of Representatives reconvened in December, former opponents of West Virginia's admission emerged as supporters because slavery's demise in the state appeared certain. Thaddeus Stevens of Massachusetts endorsed West Virginia's application, noting that the added provision "makes [West Virginia] a free State." Schuyler Colfax of Indiana agreed, expressing his "peculiar pleasure" that West Virginians "have provided for the ultimate extinction of slavery." "123 On December 10, representatives passed West Virginia's statehood application, 96-55. West Virginia's statehood bill next required Lincoln's signature. ${ }^{124}$

\footnotetext{
${ }^{122}$ Stealey, West Virginia's Civil War-Era Constitution, 105. Willey also successfully removed the additional counties included in the committee's bill. As Richard Curry notes, twenty of the twenty-three votes cast for West Virginia's admission came from Republicans. Four radical Republicans, including Sumner, and thirteen conservative senators joined in opposition to statehood. Curry, House Divided, 104.

123 "U.S. House of Representatives Debate on West Virginia statehood, December 9, 1862," A State of Convenience: The Creation of West Virginia [http://www.wvculture.org/history/statehood/ushousedebate120962.html][accessed 26 July 2015]. 124 "U.S. House of Representatives Debate on West Virginia statehood, December 10, 1862," A State of Convenience: The Creation of West Virginia [http://www.wvculture.org/history/statehood/ushousedebate121062.html][accessed 26 July 2015]. Opposition for West Virginia's admission from Virginia representatives existed. Joseph E. Segar, a Virginia Unionist representing the Eastern Shore, maintained that West Virginians had adopted a "pro-slavery constitution" but Congress imposed an "anti-slavery one" for voters to accept or reject. Segar implored Congress to allow West Virginians to decide the institution's future in its borders. Segar also feared that unionists in eastern Virginia would be vulnerable to Confederate reprisals once the Restored Government of Virginia in Wheeling turned into the West Virginia state government. Finally, Segar appealed to Virginia's "rich cluster of glorious memories and associations," denouncing the attempt to create two Virginia's and sully the state's history.
} 
The bill admitting West Virginia arrived on Lincoln's desk on December 22. Lincoln felt conflicted. Issues of slavery, constitutionality, and timing vexed the president, leading him to solicit arguments from cabinet members concerning the state's admission. ${ }^{125}$ On December 31 , 1862, President Lincoln concurred with those cabinet members who agreed that West Virginia's admission was “expedient” and constitutionally sound. West Virginians' loyalty to the Union and their "aid" in fighting the rebellion manifested residents' unwavering devotion to the federal government, Lincoln declared. The addition of the "Willey Amendment" ensured that "slave soil" would become "free," what Lincoln considered an "irrevocable encroachment upon the cause of the rebellion." The president applauded West Virginians' "secession in favor of the constitution" and granted their request for statehood. ${ }^{126}$

West Virginia's admission into the Union would become official pending ratification of the "Willey Amendment" by a constitutional convention and by public referendum. But as Willey acknowledged, secessionists in the proposed state would wield the gradual emancipation clause against statehood supporters. These secessionists constituted a mixture of Confederate sympathizers, residents opposed to "congressional dictation," or opponents to statehood on all grounds. Secessionists' planned to defeat the amendment by branding it as an abolitionist attempt to foist racial equality upon white West Virginians, what John J. Davis characterized as

125 "Opinions of Lincoln's Cabinet on the Constitutionality of West Virginia," West Virginia Archives \& History, West Virginia Division of Culture and History

[http://www.wvculture.org/history/statehood/cabinetopinions.html][accessed 26 July 2015].

126 "Opinion of Abraham Lincoln on the Admission of West Virginia," A State of Convenience: The Creation of West Virginia [http://www.wvculture.org/history/statehood/lincolnopinion.html][accessed 26 July 2015]. Virginia Governor Francis Pierpont reminded Lincoln that denying West Virginia's admission would imperil the Union cause in the region. West Virginians" "failure" to secure a new state "will ruin the Union," he warned, a foreboding prospect considering that residents" "sentiment" for the Union and for a new state "have become identical." "If one is struck down I don't know what is become of the other." Henry Dering agreed with Pierpont, declaring that Lincoln's veto "would turn all Western Va. into rebels" and "he would not have a friend in al Western Va." Francis Pierpont to Abraham Lincoln, 20 December 1862, and 30 December 1862, Francis Harrison Pierpont Letters to Abraham Lincoln, A\&M 1034, WVRHC and Henry Dering to Waitman T. Willey, 16 December 1862, Charles H. Ambler Collection, A\&M 122, Box 11, Folder 2, item 452, WVRHC. 
“degrading terms" for statehood. ${ }^{127}$ African Americans, opponents declared, would flood West Virginia and demand full and equal access to employment opportunities and the ballot box. To perpetuate and protect racial hierarchy, West Virginians must reject the "Willey Amendment." From early 1862 through 1863, pro-statehood West Virginians launched a counteroffensive against their opponents. These proponents campaigned to convince white West Virginians that ratifying the "Willey Amendment" would strengthen, not threaten, racial hierarchy. Gradual emancipation would hasten slavery's decline in the region, accelerating a demographic "whitening" already unfolding across the region. This erosion of slave labor would facilitate the expansion of "free labor," transforming West Virginia into an industrial state like Ohio and Pennsylvania. Removing slaves from the state would also remove West Virginia beyond "Jeff. Davis' kingdom," an aristocratic nation allegedly bent on disenfranchising poor white men. ${ }^{128}$ Access to the ballot box in West Virginia, though, would continue for white men regardless of wealth while the state's few African Americans would be disenfranchised. West Virginians' abolition of slavery would hasten the war's conclusion, a stinging rebuke to eastern Virginians whose zeal to protect their slave property now threatened its existence. West Virginians, supporters proclaimed, would continue to enjoy the benefits of slavery as "whiteness" would reign as the principal political ethos.

West Virginians in favor of statehood stressed the benefits of "free soil," crafting arguments that touched on contemporary political developments and Virginia's sectional history. Upon hearing the news that the House of Representatives approved West Virginia's admission, an anonymous writer in the Daily Intelligencer celebrated West Virginia's policy of "equal

\footnotetext{
${ }^{127}$ John J. Davis to Anna Kennedy, 10 December 1862, John J. Davis Family Papers, A\&M 1946, Box 1, Folder 4, WVRHC.

${ }^{128}$ Daily Intelligencer, March 23, 1863, 2.
} 
taxation, [and] equal representation." These democratic principles "have animated...all true Western Virginians for many long years." ${ }^{129}$ In a meeting in Marshall County, Brooke County merchant Campbell Tarr, a Wheeling convention delegate, blamed the "slaveholding oligarchy of Eastern Virginia" for the "whirlpool of destruction" that now engulfed the country. Tarr expressed little remorse for the "poor Eastern Virginia rebel wretches...suffering all the horrors of a desolating and destructive war." This cabal had governed by the maxim "'rule or ruin"” over the preceding decades, and without western allies, eastern Virginians faced certain destruction. ${ }^{130}$ A Marion County resident reported that his neighbors "are highly gratified with the cheering prospect of being separated from Eastern Virginia." For decades, western Virginians had lived in "Niggerdom," where all political matters centered on slavery. But West Virginia's establishment and slavery's inevitable demise had overthrown the "king" and "master" of this tyrannical domain. ${ }^{131}$ Though secessionists "might prate forever about rights, and might appeal to all our Virginia-ism, and all our nominal connection with the institutions of the South," West Virginia was not a southern state, the Daily Intelligencer asserted. Richmond legislators' attempts to make the Northwest "southern" failed because residents shared more in common with their "free soil" neighbors than eastern Virginians. ${ }^{132}$

West Virginia's transformation into a free state mirrored geographical realities, proponents maintained. As the Daily Intelligencer explained, "natural causes, silently and uncontrollably at work, were...ridding Western Virginia of slavery," as the region's "climate" and "soil" were hostile to this "foreign institution." Further, West Virginia's proximity to Ohio and Pennsylvania shaped residents' interpretation of African American bondage. The

\footnotetext{
${ }^{129}$ Daily Intelligencer, December 11, 1862, 3.

${ }^{130}$ Daily Intelligencer, August 20, 1862, 2.

${ }^{131}$ Daily Intelligencer, December 15, 1862, 2.

132 Daily Intelligencer, August 23, 1862, 2.
} 
“influence," "politics," "industries," and "sentiments" of West Virginia's neighbors "were steadily destroying the hold of slavery" in the region. ${ }^{133}$ Abolishing slavery promised to expand industrial development and place the state on a similar economic trajectory as that of Ohio and Pennsylvania. The "black spots that has given us so much trouble and retarded our growth and prosperity so greatly" would be removed, Henry Dering predicted. ${ }^{134}$ Slavery had "paralyzed" West Virginia's economic development over the preceding decades, Willey declared, while the "rapid progress" evinced by Ohio demonstrated the benefits of "free soil" and "free labor." With slavery removed, West Virginians would finally unleash the state's "inexhaustible mineral resources" that had remained undisturbed for decades. ${ }^{135}$

The labor force required to transform West Virginia into an industrial state rested on the state's "intelligent freemen." Such "men work for a purpose," one statehood proponent declared, as these white laborers sought to secure their "destiny in their own hands." Unlike slaves whose masters compelled them to labor, white workers labored because they "have families to rear and educate, and friends to entertain, and a fortune" to acquire. These "purposes" promoted a healthy body politic, "free labor" advocates declared, encouraging the development of independence, comity, and erudition. A slave's labor, though, solely benefited his master and sharpened divisive class distinctions. ${ }^{136}$ The "hardy sons of toil in our mountains" opposed

\footnotetext{
${ }^{133}$ Daily Intelligencer, January 17, 1863, 2.

${ }^{134}$ Henry Dering to Waitman T. Willey, 25 February 1863, Charles H. Ambler Collection, A\&M 122, Box 11, Folder 3, item 492, WVRHC.

${ }^{135}$ Waitman T. Willey, Address of Hon. Waitman T. Willey, Delivered before the Constitutional Convention of West Virginia, in the City of Wheeling, on the $12^{\text {th }}$ day of February, 1863, in compliance with a Resolution of that body, inviting him to do so (Wheeling: n.p., 1863), 8. [hereafter cited as Willey, Constitutional Convention of West Virginia, February 12, 1863].

${ }^{136}$ Daily Intelligencer, January 29, 1863, 1.
} 
placing "free labor...on equality with slave labor," Willey declared. ${ }^{137}$ "Vote in the New State," he instructed Wheeling laborers, and "[y]ou will have...free labor."138

The economic prosperity wrought by "free labor" would also protect white men's political rights. Confederates sought to establish an aristocratic government and place white laborers in the same economic stratum that African American slaves occupied, statehood supporters alleged. In a meeting in Triadelphia, Governor Francis Pierpont declared that Confederates believe "that the working classes are the mudsills of society" and that "capital should own labor." These beliefs revealed Confederates' true character. "Aristocracy never could tolerate the idea that the country should belong to those who rightfully cultivate it," he proclaimed. ${ }^{139}$ George Porter, Speaker of the Virginia House of Delegates in Wheeling, agreed with Pierpont. In a gathering in Wheeling, Porter confirmed that Confederates "are not a democratic people." They opposed "a government of all the people" and sought to restrict the "right of suffrage" until only property owners could vote. ${ }^{140}$ In a mass meeting in Philippi, residents maintained that Confederates sought to create a government "in which negro slavery shall be made a fundamental principle of government." Slaveholding would constitute the "basis of civil preferment, [and] of elevated social positions and distinctions." Confederates, to achieve this goal, would "open and maintain the African slave trade in all its barbarous cruelty and injustice." West Virginia's creation, however, would protect residents from these antidemocratic Confederates. ${ }^{141}$

\footnotetext{
${ }^{137}$ Willey, Constitutional Convention of West Virginia, February 12, 1863, 6.

${ }^{138}$ Daily Intelligencer, March 23, 1863, 2.

${ }^{139}$ Daily Intelligencer, August 14, 1862, 3.

${ }^{140}$ Daily Intelligencer, February 2, 1863, 2.

${ }^{141}$ Daily Intelligencer, September 3, 1862, 1.
} 
The "secessionists" that Willey feared often articulated similar arguments offered by statehood supporters. Carlile's organ, the National Telegraph, remained staunchly unionist and opposed to the Confederacy. ${ }^{142}$ The National Telegraph celebrated West Virginia's natural resources," predicting that the state would become "powerful and...wealthy" in the "not far distant" future. West Virginia should separate from the "Eastern portion of the State," the newspaper continued, as "impassable mountains" and divergent "commercial interest[s]" demonstrated that the two sections possess "nothing in common."143 Carlile expressed his continued hope for a new state, too. He remained steadfast that his actions against the new state in the Senate "will not delay our separation from Eastern Virginia." ${ }^{144}$ The Morgantown Monitor, edited and published by William P. Willey and George C. Sturgis, expressed their "general acclamation" and "relief" that residents appeared willing to accept the new state with a gradual emancipation clause. Though Congress had "intermeddled" with the state's constitution, Willey and Sturgis believed that the "people of the counties composing the proposed new State" would ratify the new constitution. ${ }^{145}$

Though these "secessionists" expressed varying degrees of opposition, their hatred for and fear of abolitionists united them. Abolitionists, conservatives maintained, sought to transform West Virginia into a colony for freed blacks, initiating a demographic "blackening" of the region" and dismantling the region's racial hierarchy. Defying congressional emancipation would hopefully convince northern Republicans and their Northwest allies that residents would not submit to the "Wheeling Abolition clique."146 This clique, West Virginia conservatives

\footnotetext{
142 National Telegraph, February 7, 1862, 2.

${ }^{143}$ National Telegraph, June 27, 1862, 2.

${ }^{144}$ John Carlile to John S. Burdett, 24 March 1862, reprinted in Wheeling Daily Press, January 5, $1863,4$.

145 Morgantown Monitor, February 21, 1863, 3.

${ }^{146}$ National Telegraph, August 29, 1862, 2.
} 
charged, attempted to foist a constitution crafted by northern abolitionists and their allies upon residents to maintain "themselves in power and carry out their promise to the Abolitionists of New England to give the New State to them." The new constitution offered little benefit for white West Virginians. ${ }^{147}$ Indeed, a state constitution tinctured by abolitionism threatened all residents. "No matter where abolition touches," the National Telegraph maintained, "it palsies, pollutes and destroys." 148

Conservatives hoped to seize upon residents' widespread hatred for abolitionism by blurring distinctions between Republicans, abolitionists, and statehood advocates, a tactic that centered on the "inevitable nigger question."149 Gradual emancipation would not "whiten" the state but "blacken" the mountains, conservatives alleged, as African Americans would flood the state seeking employment and political and civic equality. Aided by northern abolitionists and their West Virginia allies, freed blacks would control the state. Skeptical residents needed to only look at Lincoln's draconian policies on political opponents and slaveholders for evidence of abolitionists' increasing power over the president and the administration's prosecution of the war. Abolitionists had transformed a war for the Union into a crusade for racial equality, a transformation that now targeted West Virginia.

John Carlile emerged as a prominent exponent of such views. Carlile had initially attempted to defeat the statehood movement in the Senate by enlarging West Virginia's proposed boundary, a move that signaled his wariness of the state's constitutionality. His efforts in 1862 and 1863 centered on his hatred for northern abolitionists, a group he worried would foist racial equality upon white residents. In a speech in Clarksburg, Carlile "classed all friends of the New

\footnotetext{
${ }^{147}$ Wheeling Daily Press, January 24, 1863, 2.

148 National Telegraph, September 12, 1862, 2.

${ }_{149}$ Arthur I. Boreman to Francis Pierpont, 27 February 1863, Francis Harrison Pierpont Papers, A\&M 9, Box 3, Folder 6, WVRHC. [emphasis in original]
} 
State Bill in the same category with Wendell Phillips and J.R. Giddings." The "Secessionists of this vicinity were greatly pleased with the remarks," reported Union soldier E.C. Moderwell, while "many undoubted Union men felt outraged by the same." Carlile "advised his hearers to resist Congressional interference or dictation, if needs be with the sword." ${ }^{150}$ Carlile carried this message beyond West Virginia. In Indianapolis, he assailed Republicans for "turning this war for the Constitution and the Union, into a war for the negro over the prostrate bodies of both the Constitution and the Union."151 Republicans insisted that "the existence of the institution of slavery... is incompatible with the existence of the Union," a claim Carlile labeled a "slander" against the nation's founders and motivated by visions of "power, and place, and treasuries to plunder." 152 But if Republicans succeeded in abolishing slavery, these freed blacks "would scatter over the different States, and be brought into competition with the laboring whites." The "free labor" that Republicans championed would be a chimera, while all white residents would feel abolitionism's denigrating effects. "Your alms-houses, prisons, and poor-houses would soon inform you, if you had not known it before," Carlile asserted, "that the Abolitionists' dream had been realized." White men in West Virginia and across the nation had to resist abolitionism. ${ }^{153}$

Achieving abolitionists' "dream" of racial equality began with attacking slavery. Carlile considered the institution a "right established by the Constitution," and that he "would not abolish the institution of slavery in the States where it exists." Loyal southerners should determine slavery's fate, he stressed, not northern abolitionists. ${ }^{154}$ The Wheeling Daily Press

\footnotetext{
${ }^{150}$ E.C. Moderwell to Waitman T. Willey, 24 July 1862, Charles H. Ambler Collection, A\&M 122, Box 11, Folder 2, item 439, WVRHC.

${ }^{151}$ John Carlile, Remarks of John S. Carlile, of Virginia, at the Mass Convention, at Indianapolis, on the $30^{\text {th }}$ day of July, 1862 (Washington, D.C.: Henry Polkinhorn, Steam Book and Job Printer, 1862), 4-5. [hereafter cited as Carlile, Indianapolis remarks]

${ }^{152}$ Carlile, Indianapolis remarks, 16.

${ }^{153}$ Carlile, Indianapolis remarks, 20.

${ }^{154}$ Carlile, Indianapolis remarks, 19-20.
} 
worried that statehood proponents, including Waitman Willey, exaggerated the institution's adverse characteristics in compliance with abolitionists' wishes. "Willey enlarged considerably on the evils of slavery," the newspaper charged, as such accusations threatened "the very framework of our existing civilization.” Abolishing slavery would only appease northern abolitionists like "Sumner," "Lovejoy," and "Wendell Phillips," along with Daily Intelligencer "Editor [Archibald] Campbell and the Custom House clique."155 At an anti-statehood meeting in Parkersburg, gatherers worried that abolitionists "claim a great moral victory" with slavery's destruction in western Virginia. Any resident who voted for the "Willey Amendment" and statehood in general sanctioned the "purpose and principles of the Abolition party, whether they are so in heart or not." A vote for statehood only strengthened abolitionists, opponents declared. ${ }^{156}$

President Lincoln's Emancipation Proclamation deepened conservatives' convictions that abolitionists demanded slavery's destruction. Lincoln “obey[ed] the behests of the insane fanatics he has encouraged around him," the National Telegraph alleged, notably those "most ultra men of the northern faction.” Unionists in Kentucky, Missouri, and Western Virginia, confronted by the president's "contemptuous disregard" for their loyalty, now "must surrender to the fanatics of Massachusetts, New Hampshire, and the Western Reserve."157 The enlistment of African Americans incensed conservatives. West Virginia politicians who supported such a measure "must think [their] constituents [to be] among the most narrow, hidebound and contracted of men, if they would support an act, so objectionable" that the bill's "grossness" was manifest to everyone. ${ }^{158}$ Arthur Boreman reported that numerous Union soldiers "are opposed to

\footnotetext{
155 Wheeling Daily Press, February 14, 1863, 2.

156 Wheeling Daily Press, March 23, 1863, 4.

${ }^{157}$ National Telegraph, September 26, 1862, 2. [emphasis in original]

158 Wheeling Daily Press, February 19, 1863, 2.
} 
the arming and making soldiers of negroes," and predicted that the policy would "produce disquietude, desertions, and...serious demoralization." "159 Still, Republicans persisted in arming African Americans, a policy that would lead to the "extermination of both races in the slaveholding States." These same men, claimed the National Telegraph, also endorsed the "Willey Amendment."160

The 1862 mid-term elections offered hope to conservatives that "Abolition rule is drawing to a close" and that the statehood movement would be foiled. ${ }^{161}$ West Virginia conservatives interpreted Republicans' loss of thirty-two seats in the House of Representatives as a repudiation of Lincoln's unconstitutional policies, including the suspension of habeas corpus and authorizing military trials for "all rebels and insurgents, their aiders and abettors... and all persons discouraging volunteer enlistments, resisting militia drafts, or guilty of any disloyal practice."162 This blanket condemnation smacked of executive tyranny and abolitionist meddling, according to conservatives. Lincoln's “band of demons may be able to construe anything they like into disloyalty," the Charleston Guerilla charged. ${ }^{163}$ These "arbitrary arrests...were not made for the benefit of the country, but in behalf of the Abolition party," the Wheeling Daily Press exclaimed, as the arrests "reduce[d] the opponents of that party to such an extremity of fear and trepidation that they would offer no political resistance to its universal

\footnotetext{
${ }^{159}$ Arthur I. Boreman to Francis Pierpont, 27 February 1863, Francis Harrison Pierpont Papers, A\&M 9, Box 3, Folder 6, WVRHC.

${ }^{160}$ National Telegraph, December 5, 1862, 2.

${ }^{161}$ National Telegraph, October 24, 1862, 2. As James McPherson and James Hogue argue, though, conservatives poorly misread the election results. Democrats gained seats in traditionally Democratic districts across the lower North, while Republicans gained five seats in the Senate and suffered a small net-loss of seats in the House of Representatives. Republicans swept New England, the upper North, the two Pacific states, and the border states. James M. McPherson and James K. Hogue, Ordeal by Fire: The Civil War and Reconstruction, $4^{\text {th }}$ ed. (New York: McGraw-Hill, 2010), 320.

162 "A Proclamation on the Suspension of Habeas Corpus, 1862," The Gilder Lehrman Institute of American History [http://www.gilderlehrman.org/sites/default/files/content-images/06099p1_0.jpg][accessed 29 July 2015].

${ }^{163}$ Guerilla [Charleston], October 3, 1862, 2.
} 
domination." Governor Pierpont allegedly "hankered" after similar power, "copying upon the Washington tyrants" to remove "obstacle[s] to his political projects," including the creation of West Virginia. ${ }^{164}$

Pierpont's quest for unconstitutional executive powers akin to Lincoln's demonstrated to conservatives that the statehood movement represented an abolitionist scheme to impose racial equality. Republicans, allied with abolitionists, promised much with West Virginia's creation but their promises rang hollow. "Coming in as the Free Speech, Free Vote, Free Soil and Free man's party," Republicans offered "flimsy fictions about what great things are come to the New State" the Wheeling Daily Press claimed. ${ }^{165}$ Republicans" "sole aim," "every act," and "highest ambition...irrespective of their own race or their government," the Morgantown Monitor protested, "is for the negro." Republicans' "speeches are for the negro; their votes are for the negro; [and] their taxes are for the negro." Despite the "wild and reckless theories" expounded by "Abolitionists, fanatics, and many leaders of the Republican party," African Americans constituted an "inferior race, deficient in judgment, and incapable of self-government." This "inferior race" would clamor for political and social equality with West Virginia's founding; would residents sanction such actions? ${ }^{166}$ Triadelphia residents would resist such efforts. "We look upon the effort to place the African upon an equality with the white man in Western Virginia as vain and foolish," residents declared during a mass meeting. Previous attempts of imposing racial equality had failed, "bring[ing] demoralization and ruin to both" races and had threatened to "destroy the best interests of our country." Welcoming "free negroes into Western

\footnotetext{
${ }^{164}$ Wheeling Daily Press, January 5, 1863, 4.

165 Wheeling Daily Press, February 27, 1863, 2.

166 Morgantown Monitor, February 21, 1863, 2.
} 
Virginia," Triadelphia residents further averred, was "unwise and ruinous to the order and good morals of our society." These West Virginians promised resistance to abolitionists' efforts. ${ }^{167}$

West Virginians" opposition to the "black toadies" that advocated statehood reflected their concern that a new state would overturn the region's established racial hierarchy. ${ }^{168} \mathrm{~A}$ "majority" of residents opposed the "negro-equalizing amendment" known as the "Willey Amendment," one conservative newspaper declared, but military and political authorities at the behest of abolitionists prevented a full and open discussion of the issue. ${ }^{169}$ West Virginians are to be "enslaved, and...Africanized" if voters ratified the "Willey Amendment," the Clarksburg Patriot warned. ${ }^{170}$ Wheeling abolitionists "would not pass the New State bill without imposing the condition that it should be an Abolition State, and a roosting and lurking place for the negroes." ${ }^{171}$ Statehood supporters hoped to transform West Virginia into "a colony for runaway negroes," welcoming African Americans with the promise of liberation by the "Willey Amendment."172 The National Telegraph suggested renaming the amendment "An act to Africanize North Western Virginia, and to enslave the white inhabitants thereof," a more accurate representation of the amendment's purpose. ${ }^{173}$ "Give us a new State, unAbolitionized," the Wheeling Daily Press demanded, "a new State without the secret machinery which is to guide its control and direction into Abolition." 174 Protecting West Virginians' racial hierarchy demanded that residents oppose this abolitionist attempt to foist gradual emancipation upon unwilling residents, even if this opposition undermined the statehood movement. As the

\footnotetext{
167 Wheeling Daily Press, March 9, 1863, 2.

${ }^{168}$ John J. Davis to Anna Kennedy, 7 December 1862, John J. Davis Family Papers, A\&M 1946, Box 1, Folder 4, WVRHC.

${ }^{169}$ Wheeling Daily Press, March 16, 1863, 2.

${ }^{170}$ Clarksburg Patriot, March 20, 1863, 2.

171 Wheeling Daily Press, March 11, 1863, 2. [emphasis in original]

172 National Telegraph, November 21, 1862, 2.

${ }^{173}$ National Telegraph, November 7, 1862, 2.

${ }^{174}$ Wheeling Daily Press, February 19, 1863, 2.
} 
Clarksburg Patriot proclaimed, "every man who is opposed to making Western Virginia a free negro colony" must reject the new state. ${ }^{175}$

Statehood proponents, though, maintained that West Virginia's creation guaranteed and protected "whiteness," even without slavery. West Virginia's admission into the Union ensured that, regardless of the war's outcome, Deep South planters would not politically enslave white residents or consider them "like slaves on the block." 176 The "Willey Amendment" would compel slaveholders to sell or emancipate their chattel, while the prohibition on importing slaves would further "whiten" the Mountain State. And with a climate inhospitable for freed blacks or plantation agriculture, African Americans had little incentive to remain in the state. The demographic "whitening" that would unfold across West Virginia promised a thorough "whitening" of the political process, too.

West Virginia's demographic "whitening" had been unfolding for years, statehood proponents declared, as census data revealed a decline in the slave population. "The end of slavery is a foregone conclusion," the Wellsburg Herald insisted, with the institution's "health...beyond the skill of the leech." 177 In the northern panhandle, both slavery and "free negroes" have been "dead letters," and John G. Jacob believed that the "entire free black population can be counted on the fingers." ${ }^{178}$ Waitman Willey, a slaveholder, agreed with Jacob. Willey considered the number of African American slaves in West Virginia "too small to stand in the way of the public good." Further, the state's "geographical situation" meant "that slavery could never exist here to any great extent, even if it were desirable to have it." West Virginians' agricultural and manufacturing interests required free labor, Willey asserted, not slave labor.

\footnotetext{
175 Clarksburg Patriot, February 27, 1863, 2.

${ }^{176}$ Willey, Constitutional Convention of West Virginia, February 12, 1863, 1.

177 Wellsburg Herald, June 20, 1862, 2.

${ }^{178}$ Wellsburg Herald, February 13, 1863, 2.
} 
"Why then should we want slavery here?" Faced with a declining slave population, Willey and other pro-statehood members implored West Virginians to hasten that demographic shift and, in the process, fully inaugurate free labor. ${ }^{179}$

Emancipating African American slaves raised the question of freed blacks' status in the new state. West Virginians held a "deep and universal prejudice against this class of persons," confessed one statehood proponent. ${ }^{180}$ Statehood opponents wielded this question "with considerable success," William P. Willey boasted, as he and his ilk predicted that West Virginians "will soon be overrun with them." 181 Waitman Willey acknowledged that adversaries "clamor[ed] about the danger of free-negro-ism," but he and other advocates believed that African Americans would not constitute a problem in West Virginia. ${ }^{182}$ A "very large proportion of the slaves will be converted into money and started Southward," the Wellsburg Herald declared. ${ }^{183}$ "[O]ur Northern negrophobists" further reasoned that "free negroes will remain where they were born and continue to work for their masters," especially those on southern plantations. The Herald predicted that the Emancipation Proclamation would accelerate the "current of negro travel...southward," draining the African American population and whitening the Upper South. ${ }^{184}$

But would the few African Americans who remained increase competition in the job market and depress wages? Statehood opponents maintained that West Virginia's founding would trigger a flood of freed blacks, where "every nigger" would push "a white man out of employment" and Wheeling "Germans... would all be turned out of employment and free

\footnotetext{
${ }^{179}$ Willey, Constitutional Convention of West Virginia, February 12, 1863, 6.

${ }^{180}$ Daily Intelligencer, March 19, 1863, 1.

${ }^{181}$ William P. Willey to Waitman T. Willey, 31 January 1863, Charles H. Ambler Collection, A\&M 122, Box 11, Folder 3, item 482, WVRHC.

${ }^{182}$ Willey, Constitutional Convention of West Virginia, February 12, 1863, 10.

${ }^{183}$ Wellsburg Herald, February 13, 1863, 2.

${ }^{184}$ Wellsburg Herald, October 24, 1862, 2.
} 
negroes substitute[d] in their stead." ${ }^{185}$ Statehood promoters dismissed this baseless rumor. African Americans "will seek menial employment as they always and everywhere do," one supported declared. ${ }^{186}$ "The hotel, the barber shop, [and] the steamboat, are the paradise of the free negroes," answered another proponent, as blacks would labor as "waiters, porters, barbers or hostlers" while avoiding any "mechanical employment." These service occupations reinforced racial hierarchy, as African Americans would labor in subordinate industries while white residents occupied more prestigious positions. This unnamed author assured West Virginians that African Americans "naturally adapt themselves" to those "peculiar services," calming fears that freed blacks would challenge that labor hierarchy. ${ }^{187}$

African Americans' subordinate position reflected the will of Providence, a universal truth that statehood supporters endorsed. "How can the negro, whom God has made so inferior to the white, morally, intellectually and physically, ever be made his equal[?]"188 West Virginians received confirmation of such beliefs from minstrel shows. These shows, performed in Wheeling since the early 1850s, offered a popular cultural performance that allowed audience members to express their racial anxieties and collective fears of African Americans. ${ }^{189}$ For example, in March 1863, Sam Sharpley announced that his noted "Ethiopian Iron Clads" would perform in Wheeling. ${ }^{190}$ The Wheeling Daily Intelligencer reported that the minstrels' comedic performance "makes hosts of friends and admirers," and that Sharpley "has few if any superiors."191 Minstrels' mockery of African Americans reinforced statehood advocates'

\footnotetext{
${ }^{185}$ Daily Intelligencer, December 18, 1862, 1 and Daily Intelligencer, February 10, 1863, 1.

${ }^{186}$ Daily Intelligencer, March 19, 1863, 1.

${ }^{187}$ Daily Intelligencer, January 14, 1863, 1.

188 Daily Intelligencer, March 12, 1863, 1.

${ }^{189}$ Lott, "Blackface and Blackness," 13. For example, see Daily Evening Argus and Wheeling Commercial Advertiser, May 27, 1852, 2, 3.

${ }^{190}$ Daily Intelligencer, March 14, 1863, 2.

${ }^{191}$ Daily Intelligencer, March 13, 1863, 3.
} 
assertions that the "ignorant African slave" and its "offspring" were unsuited to the labor required in West Virginia's economy. White laborers in West Virginia, not African Americans, would provide the labor needed to unleash the new state's mineral resources. ${ }^{192}$

The menial employment African Americans occupied reflected their political status in the new state, too. "The hackneyed song of negro equality, negro jurors, and the like, is the old argument of secessionists," complained a resident in the Daily Intelligencer. ${ }^{193}$ This "old argument" was impossible in West Virginia, supporters explained, because the new state "will have the strongest anti-free negro laws of any loyal State in the Union." West Virginia would enforce the "old laws of Virginia," laws characterized as "severe and restrictive enough to meet the fears of the most timorous."194 Article 11, Section 8 of West Virginia's proposed constitution stated that the "common law and the laws of the State of Virginia" concerning free African Americans would remain untouched. These laws included forced removal of freed blacks older than twenty-one; imprisoning individuals who transported blacks into the state; and imposing fines on African Americans who refused to leave the state. Corporal punishment against this last group would also be enforced. Slavery's shadow would still linger over the mountains even though the institution would soon no longer officially exist. ${ }^{195}$

Slavery's demise not only benefited West Virginia but the entire state, as the institution's death in the Mountain State would hasten the war's conclusion. "This is a Pro-Slavery Rebellion," the Fairmont National declared, "fomented by slaveholders, and for Slavery's sake." West Virginia's admission would assist in slavery's “overthrow and extinction."196 Many

\footnotetext{
192 Daily Intelligencer, January 28, 1863, 1.

${ }^{193}$ Daily Intelligencer, July 31, 1862, 1.

${ }^{194}$ Daily Intelligencer, February 10, 1863, 2. Such restrictions may have included barring African Americans from carrying a gun, testifying against whites in court, and serving on juries or voting.

${ }^{195}$ Constitutional Convention of West Virginia, 12 February 1863 [http://www.wvculture.org/history/statehood/cc021263.html][accessed 31 July 2015].

196 Fairmont National, April 4, 1863, 2.
} 
statehood advocates endorsed Lincoln's Emancipation Proclamation as a similar means of destroying the Confederacy and ending the war. The Wellsburg Herald believed that the proclamation would "speedily bring the war to an issue." 197 In a new state mass meeting in Ohio County, residents "hail[ed] the President's emancipation proclamation as an efficient means of destroying the prime cause and backbone of the present malignant and unholy rebellion." 198 Ending the war would also hopefully end the guerilla conflict that had terrorized residents. Arthur Boreman reported that counties below the northern panhandle were "not safe for a loyal man" and recommended that loyalists remain within "sight of the Ohio River." 199 Virginia Representative Jacob B. Blair of Parkersburg instructed Willey to hold "the election [on the new constitution] as early as possible before warm weather when the guerrillas can infest the mountains and prevent the people from voting." With the state's future assured, such attacks would hopefully cease. ${ }^{200}$

The constitutional convention that reconvened in February 1863 enacted few substantive changes to the constitution ratified by voters the previous year. Compensating loyal slaveholders emerged as the most divisive issue, with James Brown of Kanawha demanding federal compensation for loyal slaveholders who immediately emancipated their slaves and James S. Wheat of Morgan County suggesting that funds derived from sale of Confederate property,

\footnotetext{
${ }^{197}$ Wellsburg Herald, September 26, 1862, 2.

${ }^{198}$ Daily Intelligencer, March 14, 1863, 2. Not all statehood supporters supported the Emancipation Proclamation, however. Chester Hubbard considered the proclamation "as the worst error he has made, wholly ineffective for any good purpose, and productive of all evil and only evil." Still, Hubbard stated that "I stand by the administration." Chester Hubbard to William Hubbard, 11 November 1862, Hubbard Family Papers, A\&M 805, WVRHC.

${ }^{199}$ Arthur I. Boreman to Francis Pierpont, 27 February 1863, Francis Harrison Pierpont Papers, A\&M 9, Box 3, Folder 6, WVRHC. [emphasis in original]

${ }^{200}$ Jacob B. Blair to Waitman T. Willey, 14 February 1863, Charles H. Ambler Collection, A\&M 122, Box 11, Folder 3, item 486, WVRHC and 1860 U.S. Federal Census: Parkersburg, Wood, Virginia; Roll: M653_1384; Page: 507; Image: 515; Family History Library Film: 805384 [Ancestry.com][accessed 31 July 2015].
} 
including slaves, be directed to loyal slaveholders. ${ }^{201}$ Delegates narrowly defeated Wheat's proposal, 28 to 26, while Brown's proposal suggesting immediate emancipation failed to garner much support. ${ }^{202}$ Rather, in a unanimous vote, delegates approved the "Willey Amendment," 54-0, while agreeing to petition the federal government for two million dollars for loyal slaveholders. ${ }^{203}$ West Virginia voters would ratify or reject the new constitution on March 26, the final obstacle to statehood.

On March 26, West Virginia residents and soldiers voted overwhelmingly to ratify the new state constitution with the "Willey Amendment," 28,318 in favor to 572 opposed. ${ }^{204}$ Upon receiving the returns, on April 20 President Lincoln issued a proclamation that West Virginians had satisfied all constitutional obligations and West Virginia would be admitted into the Union on June 20, $1863 .{ }^{205}$ The Daily Intelligencer celebrated the "wonderful" results, regarding the wide margin as a "grand and overwhelming...triumph." ${ }^{206}$ West Virginians' demonstrated that they "didn't need a new nigger State" but a "free State," even though "such men as Carlile...were for the niggers" and attempted to persuade voters to that perspective, too. ${ }^{207}$ The Daily Intelligencer applauded West Virginians for abolishing slavery through the ballot box, a

${ }^{201}$ Constitutional Convention of West Virginia, February 16, 1863

[http://www.wvculture.org/history/statehood/cc021663.html][accessed 31 July 2015] and Constitutional Convention of West Virginia, February 14, 1863 [http://www.wvculture.org/history/statehood/cc021463.html][accessed 31 July 2015].

${ }^{202}$ Constitutional Convention of West Virginia, February 17, 1863

[http://www.wvculture.org/history/statehood/cc021763.html][accessed 31 July 2015].

${ }^{203}$ Constitutional Convention of West Virginia, February 17, 1863

[http://www.wvculture.org/history/statehood/cc021763.html][accessed 31 July 2015] and Constitutional Convention of West Virginia, February 20, 1863 [http://www.wvculture.org/history/statehood/cc022063.html][accessed 31 July 2015]. Congress required that West Virginia exclude from its new constitution a clause prohibiting African Americans from entering the state. Stephen D. Engle, "Mountaineer Reconstruction: Blacks in the Political Reconstruction of West Virginia," Journal of Negro History, 78, no. 3 (Summer 1993): 138.

${ }^{204}$ Curry, House Divided, 150-151. Opponents of the statehood movement instructed others opposed to West Virginia's creation to abstain from voting to protest what they considered the antidemocratic means used by supporters to force residents to accept statehood, including intimidation and ostracism at the polls.

${ }^{205}$ Curry, House Divided, 129.

${ }^{206}$ Daily Intelligencer, April 8, 1863, 2.

${ }^{207}$ Daily Intelligencer, April 9, 1863, 2. 
process that other southerners should undertake, too. Residents "did what very few people in this generation have done," the Intelligencer declared, for "they abolished slavery by their votes." While other southerners "have talked" about abolishing slavery, West Virginians "talked it and voted it." 208

Historians have echoed the laudatory tone expressed by the Daily Intelligencer. Granville Davisson Hall believed that the vote demonstrated that West Virginians were "ready to accept emancipation" and place the state on that "irresistible march" toward slavery's abolition. ${ }^{209}$ Charles Ambler and Festus P. Summers considered West Virginia's “admission.... a triumph for Abolitionists,” as residents finally inaugurated a gradual emancipation process to remove slaves from the state. ${ }^{210}$ Slavery's demise via the ballot box appears to validate interpretations offered by Sean Wilentz, William Freehling, William Link, and Stephanie McCurry. These historians emphasize the fatal struggle between African American bondage and democracy, characterizing southerners' attempts to promote equilibrium between the two institutions as ill-fated and myopic. Previous scholars of West Virginia's history echo that interpretation. Mountaineers, cognizant of slavery's incongruity with "modern" democratic principles, demanded liberation from eastern oligarchs and their peculiar institution. The Civil War offered West Virginians the opportunity to emancipate themselves from such tyranny, a microcosm of the national struggle. ${ }^{211}$

This interpretation, however, reflects the Republican memory of West Virginia's sectional history and the Civil War and overlooks the protracted and often bitter debates

\footnotetext{
${ }^{208}$ Daily Intelligencer, August 13, 1863, 2.

${ }^{209}$ Hall, Rending of Virginia, 507.

${ }^{210}$ Ambler and Summers, Mountain State, 248.

${ }^{211}$ Wilentz, Rise of American Democracy; Freehling, Road to Disunion: Secessionists at Bay; Freehling, Road to Disunion: Secessionists Triumphant; Link, Roots of Secession; Link, "This Bastard New Virginia,"”; McCurry, Confederate Reckoning
} 
concerning slavery, emancipation, and statehood. West Virginians' initial policy on slavery only prohibited the importation of African American slaves, a resolution that signaled residents' reluctance to dismantle the institution. Congressional pressure compelled West Virginians to pursue compromise, but the accord reached by politicians and ratified by voters reflected residents' continued endorsement of proslavery beliefs and democratic principles. From a practical standpoint, slavery would continue to operate in the new state for decades. The "Willey Amendment" delayed emancipation for thousands of young slaves while older slaves would remain in bondage until death. African Americans could acquire freedom through selfemancipation or through a generous master but some slaveholders, wary of losing their investment, could look for prospective buyers in nearby Kentucky or Missouri. African American bondage in West Virginia would likely continue into the twentieth-century, when a majority of statehood leaders would have entrusted their descendants to tackle the final stages of emancipation. Could shifting political and racial norms reignite this emancipation debate? How would an independent and permanent Confederate nation shape this debate? With no prospective conclusion to the Civil War by 1863, slavery's future remained uncertain but few predicted the institution's demise in the Union within only a few years. Still, regardless of the Civil War's outcome, the "politics of slavery" would figure prominently over the coming decades, cementing slavery's centrality to politics.

Slavery's influence was manifest in the new constitution. While emancipation unfolded over the proceeding decades, laws imposed on African Americans promoted and perpetuated racial hierarchy. Corporal punishment remained on the books, authorizing white authorities to mete out punishment on unrepentant blacks. Freed blacks would perform menial labor, occupying low-level service positions while white laborers occupied more prestigious and 
lucrative positions. African Americans would not "blacken" West Virginia's growing industrial sector. This economic segregation carried over into politics. Statehood leaders' refusal to endorse African American political and civil rights or countenance any status for blacks other than slavery reflected their desire to "whiten" the Mountain State. Disenfranchised and marginalized freed blacks provided similar visual evidence as enslaved African Americans before the war: politics remained the purview of white men. West Virginians' embrace of democratic reform with a new state exhibited neither a clean break from slavery nor their Virginia heritage that historians suggest. Rather, the political "whitening" residents sought with statehood reflected a continuation of antebellum norms concerning race and politics, norms constructed and refined through residents' defense of African American bondage and political equality for white men. 
Conclusion: The Long Shadow: The Politics of Slavery in West Virginia, 1863-1865

In April 1864, a slave auction occurred in Morgantown, an event the Morgantown Weekly

Post reported had "not been witnessed in our town before for many a long day." 1129 The estate of Alpheus C. Dorsey placed two slaves for sale to "liquidate a debt" of the late master.

Morgantown attorney William A. Hanway purchased African American Stephen Trimble, known as “"black Steve”" to locals, for $\$ 326$. Alpheus' widow, Eliza, purchased the other slave, Elizabeth, for $\$ 71$. The relationship, if any, between the two slaves remains unclear. ${ }^{1130}$ The Morgantown Weekly Post noted a "great deal of interest was manifested on the occasion," characterizing "sales of this kind" as a "rare occurrence in West Virginia." One year removed since statehood, West Virginians continued to exploit slavery's manifold benefits for white residents, notably commodifying slaves to settle debts. ${ }^{1131}$

Statehood failed to remove slavery or the "politics of slavery" from West Virginia. In many instances, the Mountain State's creation intensified this southern brand of politics. On June 20,1863, the Morgantown Monitor assailed what it characterized as "Abolition Unionism," a political stance shared by Republicans and abolitionists and imposed upon white Americans. Republicans and their abolition allies "would rather the Union should be eternally destroyed than that it should be restored, with slavery as an institution recognized and protected by" the Constitution, and believed in "elevating the black race to a level with the white man." This "nonsensical fanaticism" opposed what the Monitor believed most West Virginians professed, specifically that "this Government was made for the WHITE MAN and not for blacks or a mongrel

\footnotetext{
${ }^{1129}$ Morgantown Weekly Post, April 16, 1864, n.p.

${ }^{1130} 1860$ U.S. Federal Census: Morgantown, Monongalia, Virginia; Roll: M653_1364; Page: 18; Image: 24; Family History Library Film: 805364 [Ancestry.com][accessed 7 August 2015] and 1860 U.S. Federal Census:

Morgantown, Monongalia, Virginia; Roll: M653_1364; Page: 14; Image: 20; Family History Library Film: 805364 [Ancestry.com][accessed 7 August 2015]. The 1860 U.S. Federal Census shows that Dorsey owned four slaves, two male (ages 36 and 18) and two female (ages 21 and 17). The census, however, does not record their names.

${ }^{1131}$ Morgantown Weekly Post, April 16, 1864, n.p.
} 
race." On West Virginia's founding, the Monitor reminded its audience that the nation and the state remained the purview of white men, not African Americans. ${ }^{1132}$

Conservatives continued to warn residents about the dangers of freed blacks in the Mountain State. During his congressional campaign in 1863, Willis De Hass, a self-proclaimed Democrat and conservative, reminded voters that he was "the White Man's Candidate." His opponent, Jacob B. Blair, "is the Candidate for the NEGRO.” While De Hass supports the “UNION" and "DEMOCRACY," Blair advocated "DIS-UNION" and "ABOLITIONISM."1133 The "friends of Mr. Lincoln and the African" had protracted the war so "that the institution of slavery...be wiped out" and "the white people themselves...be swept from the face of the earth," claimed the Wheeling Daily Register. The Register supported a change in leadership before abolitionists' dreams became manifest. ${ }^{1134}$

Leading up to the 1864 presidential election, conservatives continued to remind West Virginians that abolitionists and some Republicans sought to undermine racial purity and hierarchy. The Weekly National Telegraph in Clarksburg assailed "misguided philanthropists" who "place[d] [African Americans] upon an equality with the white man." This equality extended into the political and social spheres. Abolitionists "would not only have [African Americans] vote in elections, but permit him to testify in courts of justice against a white man, and occupy the same jury box with him," empowering freed blacks with "all the privileges and immunities of the white man." Though West Virginians and residents of other union slave states "have their prejudices against anything that savors of negro equality," abolitionists persisted with their "infernal radicalism." The freedom that abolitionists provided African Americans

\footnotetext{
1132 Morgantown Monitor, June 20, 1863, 2.

1133 Daily Intelligencer, October 22, 1863, 2.

1134 Wheeling Daily Register, June 13, 1864, 2.
} 
constituted the "freedom to commit crime," including "[d]runkeness, debauchery, riot and bloodshed." Emancipation was a "damnable" policy, the Telegraph insisted. ${ }^{1135}$ Such accusations assisted Democratic nominee George McClellan's presidential candidacy. Though McClellan lost the state, his performance in West Virginia worried Republicans that the "politics of slavery" would continue to shape elections. ${ }^{1136}$

As before public ratification of the "Willey Amendment," Republican and pro-statehood organs and members attempted to convince West Virginians that their new state and federal government would continue to protect white interests. The Wellsburg Herald predicted "little...trouble" with African Americans "because happily, we have few free negroes among us and nothing to invite their immigration." Other regions across the nation, notably the South, would not be as fortunate as West Virginia. Southern states, inundated with a population "helpless almost as children and ignorant as savages," could expect "more than the average amount of crime," notably "riots and insurrections." The Herald hoped the federal government would provide some form of schooling and assistance to educate and elevate African Americans. ${ }^{1137}$

These benefits provided to freed blacks, though, paled in comparison to the advantages offered to white residents now emancipated from slaveholders' political tyranny, the Fairmont National insisted. "[W]e imperatively declare that all the good that the black minority will win from the abolition of slavery is eclipsed by the surpassing good to the white majority." This war to abolish slavery would ultimately benefit white residents, while merely providing the "justice"

\footnotetext{
1135 Weekly National Telegraph [Clarksburg], August 5, 1864, 2.

${ }^{1136}$ Fairmont National, November 12, 1864, 2; Daily Intelligencer, November 11, 1864, 2; and Daily Intelligencer, November 14, 1864, 2. Vote totals for some northwestern counties showed a close race between Lincoln and McClellan. Lincoln carried Ohio County by a mere 131 votes and Wirt County by 54 votes. Lincoln, though, won Marion by a more comfortable 569 vote margin and Taylor County by 436 votes. Lincoln won West Virginia, receiving 23,799 votes to McClellan's 11,078.

1137 Wellsburg Herald, July 24, 1863, 2.
} 
that African Americans deserved. ${ }^{1138}$ The Fairmont National encouraged residents to avoid "missegenation" with African Americans, a lifestyle it characterized as "social degradation." Though such racial mixing occurred between masters and slaves, West Virginians "are opposed to the mixing of the white with the black races." Interracial West Virginians undermined the clear racial divide that residents and the state's founders envisioned and promised in $1863 .{ }^{1139}$

One of those founders faced an intense reelection campaign in 1865. Waitman Willey's expiring senatorial term encouraged some West Virginians to oppose his reelection because of his previous stances on slavery. "Mr. Willey has always been the inveterate partizan of slavery," the Fairmont National declared. Though Willey blamed slavery for the current rebellion, "he votes steadfastly and consistently against knocking that prop from under it."1140 Opponents also charged him for "being an enemy to the separation of West from East Virginia" and denounced his apparent "reluctance to save the New State."1141 Indeed, Morgantown resident and West Virginia Speaker of the House Leroy Kramer informed Willey that some delegates "are very radical on the Slavery question" and "expressed fears that...you would be too pro Slavery." 1142 Some West Virginians supported Daily Intelligencer editor Archibald Campbell. His supporters characterized Campbell as "the inveterate enemy of slavery and all forms of aristocracy," though he possessed "good common sense" to reject the sentiments of a "small class of the New England anti-slavery men."1143 Morgantown attorney Edward C. Bunker reported that Campbell was "using every means" to defeat Willey, including claiming "he is entitled to all the credit for

\footnotetext{
1138 Fairmont National, April 9, 1864, 2.

1139 Fairmont National, July 16, 1864, 2.

1140 Fairmont National, January 14, 1865, 3.

${ }^{1141}$ Fairmont National, January 28, 1865, 2.

1142 Leroy Kramer to Waitman T. Willey, 25 January 1865, Charles H. Ambler Collection, A\&M 122, Box 11, Folder 6, item 612, WVRHC [emphasis in original] and 1860 U.S. Federal Census: Morgantown, Monongalia, Virginia; Roll: M653_1364; Page: 9; Image: 15; Family History Library Film: 805364 [Ancestry.com][accessed 11 August 2015].

${ }^{1143}$ Fairmont National, January 14, 1865, 3.
} 
the admission of W Va."1144 Willey won reelection despite Campbell's efforts but the debate surrounding his candidacy revealed that the "politics of slavery" would not dissipate for some time.

West Virginia's founding did little to destabilize the brand of politics that had defined the rituals and rhythms of political life in the Northwest over the preceding decades. Since the second two-party's inception in the 1820s and 1830s, the "politics of slavery" shaped parties' platforms, candidates' speeches, and voters' preferences in the Northwest. Economic, ethnocultural, and myriad political issues competed with slavery during campaign season, but each party and candidate had to convince voters that their stance on such issues would not interfere with the master-slave relationship. Though few slaves and fewer slaveholders resided in the Northwest, the institution still exerted a tremendous and powerful influence in the region.

Not all Virginians, though, believed that the Northwest followed similar political rules as other areas more heavily invested in slavery. For decades, eastern Virginians had shaped and controlled the structures and functions of the state government to further their section's interests, notably slavery. Northwesterners' efforts to reform and democratize the state constitution encountered stiff resistance from eastern elites and slaveholders who feared democracy's deleterious effects on their peculiar institution. These eastern elites doubted slavery's compatibility with democratic government. Viewed from Virginia's eastern shore, western Virginians' attempts to democratize the state allegedly reflected mountaineers' antislaveryism. During the Constitutional Convention of 1829-1830, Tidewater and Piedmont delegates defeated numerous attempts to reorganize representation on the "white basis" and to enfranchise all white

\footnotetext{
${ }^{1144}$ Edward C. Bunker to Waitman T. Willey, 24 December 1864, Charles H. Ambler Collection, A\&M 122, Box 11, Folder 6, item 598, WVRHC and 1860 U.S. Federal Census: District 2, Monongalia, Virginia; Roll: M653_1364; Page: 74; Image: 84; Family History Library Film: 805364 [Ancestry.com][accessed 11 August 2015].
} 
men irrespective of property qualifications, initiatives advocated by western reformers. Slight alterations in voting prerequisites, however, broadened enfranchisement, though not as far as reformers' desired. Western Virginians expressed their disappointment by overwhelmingly voting against the new constitution's ratification, while some contemplated a division of the state.

The frustration and apoplexy expressed by residents in 1830 convinced contemporary and modern historians that Virginia's "drift toward dissolution" accelerated when residents ratified the new constitution. A democratic, free labor west allegedly groaned under the dominion of an aristocratic, slaveholding east, a microcosm of the national struggle beginning to unfold. A closer analysis of residents' reactions following the constitution's ratification provides another narrative. Some residents endorsed the new constitution, celebrating the more lenient suffrage requirements as evidence of democracy's inevitable, if slow, march in the Old Dominion. Other residents voiced more practical concerns about annexation or dismemberment. Annexation to Pennsylvania threatened to strangle the Northwest's burgeoning industrial sector, as the competition between Pittsburgh and Wheeling would become more intense. Above all, the majority of northwesterners opposed dividing Virginia because they identified themselves as Virginians and refused to countenance any discussion of dismemberment. Only a handful of western Virginians appeared to advocate separation, a small minority whose power and influence historians have exaggerated over the preceding years.

Northwesterners deepened their fealty toward the state and slavery during the proceeding two decades. The two-party system fostered statewide alliances irrespective of sectional affiliation and encouraged broad participation in local events and campaign even though some residents remained disenfranchised. The proslavery ideology crafted by Benjamin Watkins 
Leigh, Thomas Dew, and Abel P. Upshur in the wake of the 1829-1830 Constitutional Convention and Nat Turner's Rebellion emphasized the myriad benefits provided to nonslaveholders by African American bondage. Slavery's benefits extended beyond the plantation, these authors declared, as all white men regardless of birthright, socioeconomic status, occupation, or political affiliation found their political freedom in African American's enslavement. This recruitment of northwestern allies proved important as the national crisis concerning slavery expanded in the 1850 s while Virginians set about to reform their constitution yet again.

The 1850-1851 Constitutional Convention brought slavery and democracy into sharp relief. Northwestern delegates insisted that their neighbors remained committed to the masterslave relationship and sought only to democratize the state government, not interfere with chattel slavery. Indeed, democratic reform would quiet the few lone voices opposed to Virginia's slaveholding interests. Defections from eastern ranks and support from Henry A. Wise further emboldened northwesterners who achieved an important victory with the adoption and ratification of the 1851 Constitution. The constitution represented a blending of proslavery and democratic thought. Universal male suffrage, greater representation in the state legislature, and the direct election of public officials opened politics to all white men while statutes concerning African Americans and the ad valorem taxation policy wedded slavery to the state. This development became manifest as northwestern residents deepened their engagement in the "politics of slavery" in subsequent gubernatorial and presidential elections. Indeed, eastern slaveholders' fears prior to the convention proved unfound, as northwesterners emerged as vocal and active allies of slaveholders across the Commonwealth and South. 
This influence was manifest in residents' reaction to the rise of abolitionism and the Republican Party. Whigs and Democrats blurred the distinctions between those two groups, portraying Republicans as abolitionists in disguise or as abolitionists' political allies. Both Republicans and abolitionists sought racial equality at the ballot box and in the household, opponents charged, threatening racial hierarchy and patriarchy. By portraying Republicans and abolitionists as dangers to these two traditional and established hierarchies, Whigs and Democrats appealed to practically every white man in the region, regardless of his slaveholding status. Though Republicans' professed to protect white residents' political interests through "free soil" and "free labor," few northwesterners believed such remarks. The Republican Party remained foreign to voters, as most residents retained their traditional political affiliations, even when the Whig Party collapsed. Politics and slavery remained inseparable during the 1850s.

The secession crisis in 1860-1861 did little to disturb the prevailing political dynamic of the Northwest. Residents and their representatives demanded slavery's protection but divided over the best means to achieve that end. Most northwesterners believed that political compromises, court decisions, and constitutional principles shielded slaveholders from meddling Republicans and abolitionists, even with a Republican in the White House. Remaining in the Union also protected white nonslaveholders from Deep South cotton planters, a class of elites wary of democratic government. A vocal minority protested unionists' position. The Confederate States, not the United States, offered slaveholders the maintaining that the Confederate States, secessionists insisted. Lincoln's call for troops intensified this debate, as delegates adopted the Ordinance of Secession but many northwesterners remained committed to the Union. Secessionists, however, operated in the Northwest and plagued residents' attempts of achieving consensus on statehood. 
Northwesterners' tortuous route to embracing and achieving statehood and adopting gradual emancipation reflected their desire to perpetuate established and traditional hierarchies. Foremost among these was racial supremacy. Residents agreed that "proper" racial hierarchy should continue but divided whether that could be achieved in a new state. Statehood proponents pointed to the demographic "whitening" already unfolding across the proposed state as evidence of residents' declining support for chattel slavery. This demographic reconfiguration reflected residents' increasing acceptance of "free soil" and "free labor" principles and that the proposed state's climate and proximity to northern states precluded plantation agriculture. Ratifying the "Willey Amendment" would accelerate this "whitening," too, removing African Americans from the Mountain State while creating a hostile environment for those blacks that remained. West Virginia's creation would not challenge racial hierarchy but rather reaffirm it.

Statehood opponents agreed that African Americans' inferiority remain undisturbed but questioned whether statehood could achieve that goal. These detractors worried that national Republicans and their abolitionist allies would foist civil and political equality between whites and blacks, treating the Mountain State into an interracial experiment. The "Willey Amendment" appeared poised to "blacken" the mountains by transforming West Virginia into a safe haven for African Americans. The overwhelming vote in favor of statehood, while celebrated by contemporary supporters and modern historians, obscures the common ground that statehood advocates and enemies occupied. Both groups demanded the perpetuation of racial hierarchy, African Americans' subordination, and democracy for white men; only the means of achieving that goal separated them.

West Virginia's creation upon the basis of racial democracy diminishes the celebratory and self-affirmative narratives offered by numerous modern historians. William Freehling, Sean 
Wilentz, and Stephanie McCurry, for example, emphasize slavery's impending destruction as democratic reforms transformed the slaveholding South's political landscape. Slavery's incongruity with "modern" democratic principles allegedly became unbearable for white southerners, especially for nonslaveholders in western Virginia. This interpretation, however, overlooks the strong proslavery element in the region and residents' refusal to abandon racial supremacy. Indeed, West Virginians' desire to maintain racial supremacy tempered enthusiasm for statehood and threatened to derail the entire project, with some leaders doubting West Virginia's creation. West Virginia's founding in the midst of the Civil War reflected residents' unwavering belief that racial subordination constituted a fundamental element of democratic government, a belief that would shape Reconstruction in the Mountain State and the nation. 


\section{BIBLIOGRAPHY}

\section{Primary Sources}

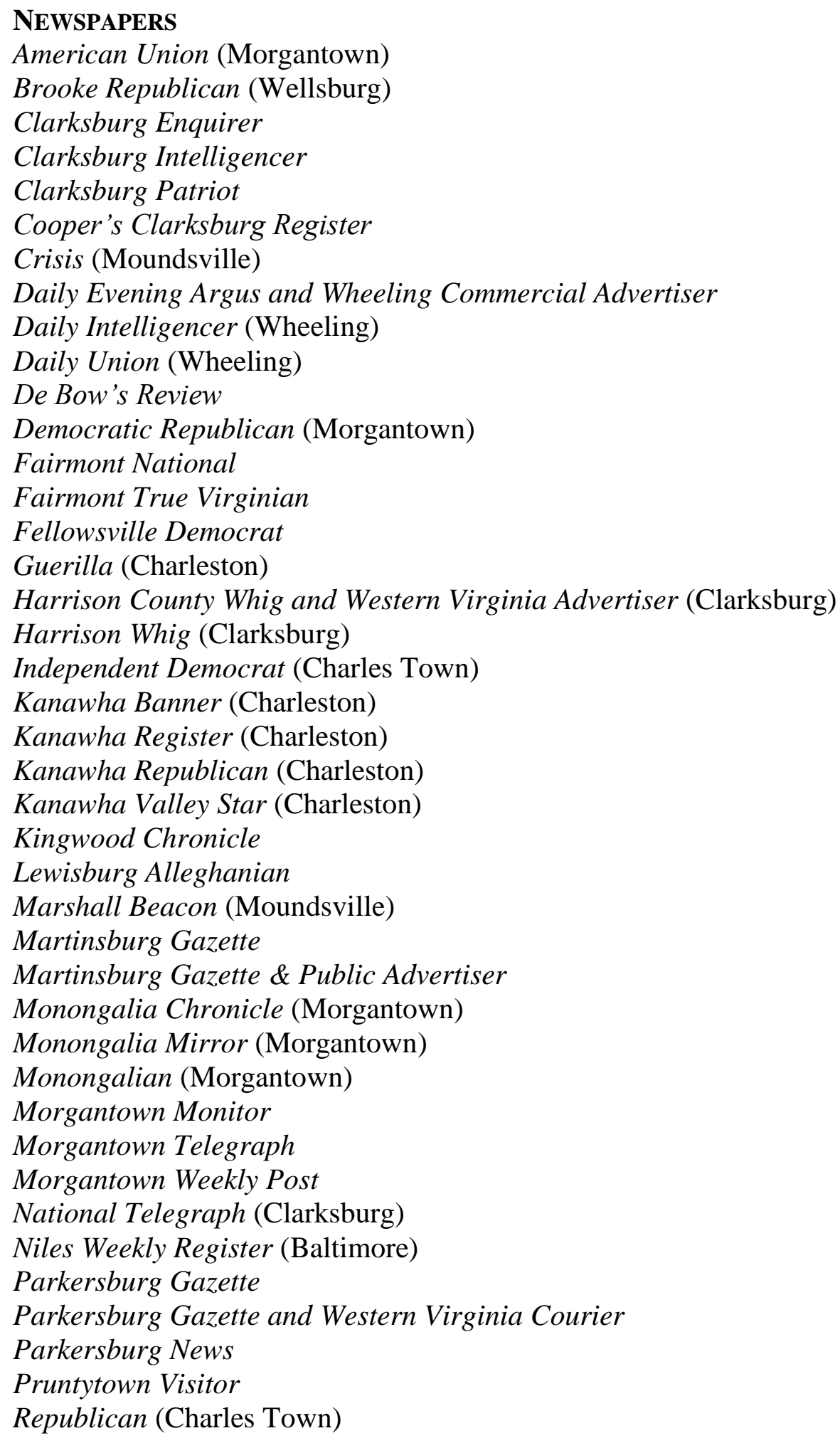


Republican Monongalia \& Preston Advertiser (Morgantown)

Richmond Enquirer

Richmond Whig

Shepherdstown Register

Southern Literary Messenger (Richmond)

Spirit of Jefferson (Charles Town)

Star of the Kanawha Valley (Charleston)

Virginia Free Press (Charles Town)

Virginia Plain Dealer (Middlebourne)

Virginia Weekly Star (Morgantown)

Weekly Campaign (Clarksburg)

Weekly National Telegraph (Clarksburg)

Weston Herald

Weston Sentinel

Wellsburg Gazette

Wellsburg Weekly Herald

Western Virginia Guard (Clarksburg)

Western Virginia Standard (Morgantown)

Western Virginia Times \& Advertiser (Wheeling)

Wheeling Argus

Wheeling Compiler

Wheeling Daily Intelligencer

Wheeling Daily Press

Wheeling Daily Register

Wheeling Gazette

Wheeling Intelligencer

Wheeling Times

\section{Printed PRimary}

Barbour, James. Speech of James Barbour, Esq., of Culpeper, in the Committee of the Whole, on the basis question, delivered in the Virginia Reform Convention, on Thursday, February 27, 1851. Richmond: R.H. Gallaher, 1851.

Berry, Henry. The Speech of Henry Berry, (Of Jefferson), in the House of Delegates of Virginia, on the Abolition of Slavery. Richmond: Thomas W. White Press, 1832.

Brodnax, William H. The Speech of William H. Brodnax (of Dinwiddie) in the House of Delegates of Virginia, on the Policy of the state with respect to its colored population. Richmond: Thomas W. White Press, 1832.

Brown, John Thompson. Speech of John Thompson Brown on the Abolition of Slavery, Delivered Wednesday, January 18, 1832. Richmond: Thomas W. White, Printer, 1832.

Carlile, John. Remarks of John S. Carlile, of Virginia, at the Mass Convention, at Indianapolis, on the $30^{\text {th }}$ day of July, 1862. Washington, D.C.: Henry Polkinhorn, Steam Book and Job Printer, 1862. 
The Civil War Papers of George B. McClellan: Selected Correspondence, 1860-1865. Edited by Stephen W. Sears. New York: Ticknor \& Fields, 1989.

Dew, Thomas R. Review of the Debate in the Virginia Legislature of 1831 and 1832. Richmond: T.W. White, 1832.

Faulkner, Charles James. The Speech of Charles Jas. Faulkner, (Of Berkeley) in the House of Delegates of Virginia, on the Policy of the State with Respect to Her Slave Population. Richmond: Thomas W. White, Printer, 1832.

Goode, William O. Speech of William O. Goode, Esq., of Mecklenburg, in Committee of the Whole, on the Basis Question, delivered in the Virginia Reform Convention, on Wednesday, April 16, 1851. Richmond: R.H. Gallaher - Republican Office, 1851.

Hamilton, Alexander, John Jay, and James Madison. The Federalist Papers. Edited by Clinton Rossiter. New York: Signet Classic, 2003.

Latrobe, Benjamin Henry. Notices of Parkersburg, Virginia, as it is in July, 1860. Baltimore: John W. Woods, 1860.

[Leigh, Benjamin Watkins]. The Letter of Appomatox to the People of Virginia: Exhibiting a Connected View of the Recent Proceedings in the House of Delegates, on the subject of the Abolition of Slavery; and a Succinct Account of the Doctrines Broached by the Friends of Abolition, in Debate; and the Mischievous Tendency of those Proceedings and Doctrines. Richmond: Thomas W. White, Printer, 1832.

Letcher, John. Speech of John Letcher, Esq., of Rockbridge, on the Basis Question. Delivered in the Committee of the Whole Convention, March 14, 1861. Richmond: Ritchies and Dunnavant, 1851.

Purkins, George W. Speech of George W. Purkins, Esq., of Halifax, in the Committee of the Whole, on the Basis Question, Delivered in the Virginia Reform Convention, on Friday, February 21, 1851. Richmond: R.H. Gallaher, 1851.

Randolph, Thomas Jefferson. The Speech of Thomas J. Randolph in the House of Delegates of Virginia, on the Abolition of Slavery. Richmond: Thomas W. White Press, 1832.

The Ruffner Pamphlet and its Endorsers. Let Everybody read and Judge for Themselves. Norfolk: Opposition Party of Norfolk, 1859.

Rutherfoord, John Coles. Speech of John C. Rutherfoord, of Goochland, in the House of Delegates of Virginia, 21 February, 1860, in favor of the proposed Conference of Southern States. Richmond: William H. Clemmitt, 1860. 
Standard, R.C. R.C. Standard, Esq., of Richmond City, in Committee of the Whole, on The Basis Question, Delivered in the Virginia Reform Convention, on Thursday, April 17, and Wednesday, May 21, 1851. Richmond: R.H. Gallaher - Republican Office, 1851.

To the People of Virginia! John Letcher and his Antecedents. Read and Circulate. Richmond: Whig Book and Job Office, 1859.

Views of the Constitution of Virginia, contained in the essay of "One of the People;" and in the Letters of Messrs. Robinson, Macfarland, Morson and Patton. In reply to a Communication from many citizens of the Richmond District. Richmond: Colin, Baptist and Nowlan, 1850.

Willey, Waitman T. Speeches of Waitman T. Willey of Monongalia County, before the State Convention of Virginia, on the Basis of Representation; on County Courts \& County Organization, and on the Election of Judges by the People. Richmond: William Culley, Printer, [1851].

. Speech of Hon. W.T. Willey of Virginia, on the Object of the War; Delivered in the Senate of the United States, December 19 and 20, 1861. Washington, D.C.: Congressional Globe Office, 1862.

- Speech of W.T. Willey of Virginia, on the Abolition of Slavery in the District of Columbia, Delivered in the United States Senate, March 20, 1862. Washington, D.C.: Towers, Printers, 1862.

—. Speech of Hon. W.T. Willey, Delivered in the United States Senate, May 29, 1862, On Presenting the Memorial of the Legislature of Virginia, requesting the consent of Congress to the erection of a new state within the jurisdiction of that State, to be called “West Virginia." Washington, D.C.: Scammell \& Co., 1862.

- Address of Hon. Waitman T. Willey, Delivered before the Constitutional Convention of West Virginia, in the City of Wheeling, on the $12^{\text {th }}$ day of February, 1863, in compliance with a Resolution of that body, inviting him to do so. Wheeling: n.p., 1863.

— A Letter from Hon. W.T. Willey, on the Redintegration of Virginia. Washington, D.C.: n.p., 1866.

. A Sketch of the Life of Philip Doddridge. Morgantown: Morgan \& Hoffman, Printers, 1875.

Wise, Henry A. Speech of Hon. Henry A. Wise of Accomac, in the Committee of the Whole, on the Basis Question, Delivered in the Virginia Reform Convention on Wednesday, Thursday, Friday, Saturday, Monday, April 23, 24, 25, 26, and 28, 1851. Richmond: R.H. Gallaher, 1851. 


\section{GOVERNMENT DOCUMENTS}

Journal of the House of Delegates of the Commonwealth of Virginia, Begun and Held at the

Capitol, in the City of Richmond, on Monday, the Fifth Day of December, One thousand Eight hundred and Thirty-one. Richmond: Thomas Ritchie, Printer, 1831.

Journal of the House of Delegates, 1848-1849. Richmond: Samuel Shepherd, 1848.

Journal of the House of Delegates, 1849. Richmond: State Government Records Collection, Library of Virginia.

Journal of the House of Delegates, of the State of Virginia, For the Session of 1852. Richmond: William F. Ritchie, 1852.

Proceedings and Debates of the Virginia State Convention of 1829-1830: to which are subjoined, the new constitution of Virginia, and the votes of the people. Richmond: S. Shepherd \& Co., 1830.

Proceedings of the Virginia State Convention of 1861, February 13 - May 1. Edited by George H. Reese. Richmond: Virginia State Library, 1965.

Register of the Debates and Proceedings of the Virginia Reform Convention. Richmond: R.H. Gallaher, 1851.

\section{Archival Collections \\ LIBRARY OF VIRGINIA, RICHMOND, VIRGINIA \\ Legislative Petitions Project}

VIRGINIA Historical SociETy, RICHMOND, VIRGINIA

John Letcher Papers

Stuart Family Papers

\section{West Virginia \& Regional History Center, West Virginia University, MORGANTOWN, WeST VIRGINIA}

Charles H. Ambler Papers

Jonathan M. Bennett Papers

Fletcher Brock Papers

Gideon D. Camden Papers

Archibald W. Campbell Papers

Fabricius A. Cather, Civil War Diaries

John J. Davis Papers

Peter Garnall Letter

Hubbard Family Papers

Monongalia County Scrapbook

Francis Harrison Pierpont Papers 
Francis Harrison Pierpont Letters to Abraham Lincoln

Pittenger Family Letters

William Price Papers

Lewis and George W. Summers Papers

Peter Goodwin Van Winkle Letter

Peter Goodwin Van Winkle Papers

William Wesley Warder Papers

Waitman T. Willey Papers

Benjamin Wilson

Wood County Records

\section{SECONDARY SOURCES}

\section{Books, Chapters, Edited Collections}

Adams, John. A Defence of the Constitutions of the Government of the United States of America. Philadelphia: Budd and Bartram, 1797.

Adams, Sean Patrick. Old Dominion, Industrial Commonwealth: Coal, Politics, and Economy in Antebellum America. Baltimore: Johns Hopkins University Press, 2004.

Ambler, Charles H. Sectionalism in Virginia from 1776 to 1861. Chicago: University of Chicago Press, 1910.

. The Life and Diary of John Floyd: Governor of Virginia, an Apostle of Secession, and The Father of the Oregon Country. Richmond: Richmond Press, 1918.

Ambler, Charles H. and Festus P. Summers. West Virginia: The Mountain State. Englewood Cliffs, NJ: Prentice-Hall, 1958.

Anderson, Benedict. Imagine Communities: Reflections on the Origin and Spread of Nationalism. New York: Verso Press, 1991.

Baldwin, John B. Interview between President Lincoln and Col. John B. Baldwin, April 4, 1861: Statements and Evidence. Staunton, VA: Spectator Office, 1866.

Barnes, L. Diane. "Industry and Its Laborers, Free and Slave in Late-Antebellum Virginia." In The Old South's Modern Worlds, edited by L. Diane Barnes, Brian Schoen, and Frank Towers, 189-206. New York: Oxford University Press, 2011.

Beeman, Richard. The Varieties of Political Experience in Eighteenth-Century America. Philadelphia: University of Pennsylvania Press, 2004.

Berlin, Ira. Many Thousands Gone: The First Two Centuries of Slavery in North America. Cambridge: Belknap Press of Harvard University Press, 1998. 
Bonner, Robert E. Mastering America: Southern Slaveholders and the Crisis of American Nationhood. Cambridge: Cambridge University Press, 2009.

Bruce, Jr., Dickson. The Rhetoric of Conservatism: The Virginia Convention of 1829-30 and the Conservative Tradition in the South. San Marino, CA: Kingsport Press, 1982.

Cooper, Jr., William J. The South and the Politics of Slavery, 1828-1856. Baton Rouge: Louisiana State University Press, 1978.

Crofts, Daniel W. Reluctant Confederates: Upper South Unionists in the Secession Crisis. Chapel Hill: University of North Carolina Press, 1989.

Curry, Richard Orr. A House Divided: A Study of Statehood Politics and the Copperhead Movement in West Virginia. Pittsburgh: University of Pittsburgh Press, 1964.

Curtis, Christopher Michael. Jefferson's Freeholders and the Politics of Ownership in the Old Dominion. New York: Cambridge University Press, 2012.

Dunaway, Wilma. The African-American Family in Slavery and Emancipation. New York: Cambridge University Press, 2003.

Dunn, Susan. Dominion of Memories: Jefferson, Madison, and the Decline of Virginia. New York: Basic Books, 2007.

Edwards, Laura F. The People and their Peace: Legal Culture and the Transformation of Inequality in the Post-Revolutionary South. Chapel Hill: University of North Carolina Press, 2009.

Etcheson, Nicole. The Emerging Midwest: Upland Southerners and the Political Culture of the Old Northwest, 1787-1861. Bloomington: Indiana University Press, 1996.

Fischer, David Hackett and James C. Kelly. Bound Away: Virginia and the Westward Movement. Charlottesville: University of Virginia Press, 2000.

Foner, Eric. Free Soil, Free Labor, Free Men: The Ideology of the Republican Party before the Civil War. New York: Oxford University Press, 1970.

Fones-Wolf, Ken. "Caught Between Revolutions: Wheeling Germans in the Civil War Era." In Transnational West Virginia: Ethnic Communities and Economic Change, 1840-1940, edited by Ken Fones-Wolf and Ronald L. Lewis, 19-47. Morgantown: West Virginia University Press, 2002.

Ford, Lacy. Deliver Us From Evil: The Slavery Question in the Old South. New York: Oxford University Press, 2009. 
Freehling, Alison Goodyear. Drift Toward Dissolution: the Virginia Slavery Debate of 18311832. Baton Rouge: Louisiana State University Press, 1982.

Freehling, William W. The Road to Disunion: Secessionists at Bay, 1776-1854. New York: Oxford University Press, 1990.

- The Reintegration of American History: Slavery and the Civil War. New York: Oxford University Press, 1994.

- The South vs. the South: How Anti-Confederate Southerners Shaped the Course of the Civil War. New York: Oxford University Press, 2001.

—. The Road to Disunion: Secessionists Triumphant, 1854-1861. New York: Oxford University Press, 2007.

Freehling, William W. and Craig M. Simpson. Showdown in Virginia: The 1861 Convention and the Fate of the Union. Charlottesville: University of Virginia Press, 2010.

Green, Fletcher M. Constitutional Development in the South Atlantic States, 1776-1860: A Study in the Evolution of Democracy. New York: W.W. Norton, 1966.

Hall, Granville Davisson. The Rending of Virginia: A History. Chicago: Mayer and Miller, 1902.

Harrold, Stanley. Border War: Fighting over Slavery before the Civil War. Chapel Hill: University of North Carolina Press, 2010.

Haymond, Henry. History of Harrison County, West Virginia: From the Early Days of Northwestern Virginia to the Present. Morgantown: Acme Publishing Company, 1910.

Holt, Michael F. The Political Crisis of the 1850s. New York: Wiley, 1978.

- The Rise and Fall of the American Whig Party: Jacksonian Politics and the Onset of the Civil War. Oxford: Oxford University Press, 1999.

Howe, Daniel Walker. What Hath God Wrought: The Transformation of America, 1815-1848. New York: Oxford University Press, 2007.

Inscoe, John C. Mountain Masters, Slavery, and the Sectional Crisis in Western North Carolina. Knoxville: University of Tennessee Press, 1989.

Isaac, Rhys. The Transformation of Virginia, 1740-1790. Chapel Hill: University of North Carolina Press, 1992.

- Landon Carter's Uneasy Kingdom: Revolution and Rebellion on a Virginia Plantation. Oxford: Oxford University Press, 2004. 
Jacobs, John G. Brooke County, being a Record of Prominent Events, Occurring in Brooke County, W.VA., from the Settlement of the Country, until January 1, 1882. Wellsburg: Herald Office, 1882.

Keyssar, Alexander. The Right to Vote: The Contested History of Democracy in the United States. New York: Basic Books, 2000.

Knowles, Anne Kelly. "Wheeling Iron and the Welsh: A Geographical Reading of Life in the Iron Mills." In Transnational West Virginia: Ethnic Communities and Economic Change, 1840-1940, edited by Ken Fones-Wolf and Ronald L. Lewis, 217-242. Morgantown: West Virginia University Press, 2002.

Kolp, John Gilman. Gentlemen and Freeholders: Electoral Politics in Colonial Virginia. Baltimore: Johns Hopkins University Press, 1998.

Lang, Theodore F. Loyal West Virginia from 1861 to 1865: With an Introductory Chapter on the status of Virginia for Thirty Years prior to the War. Baltimore: Deutsch \& Co., 1895.

Levine, Bruce. The Spirit of 1848: German Immigrants, Labor Conflict, and the Coming of the Civil War. Urbana: University of Illinois Press, 1992.

Lewis, Virgil A. How West Virginia Was Made: Proceedings of the First Convention of the People of Northwestern Virginia at Wheeling, May 13, 14, and 15, 1861, and the Journal of the Second Convention of the People of Northwestern Virginia at Wheeling, which assembled June 11th, 1861 and Continued in Session until June 25th. Adjourned until August 6, 1861. Reassembled on that date, and continued in session until August $21^{\text {st }}$, when it adjourned sine die. Charleston, WV: News-Mail Company Public Printers, 1909.

Link, William A. Roots of Secession: Slavery and Politics in Antebellum Virginia. Chapel Hill: University of North Carolina Press, 2003.

Lott, Eric. "Blackface and Blackness: The Minstrel Show in American Culture." In Inside the Minstrel Mask: Readings in Nineteenth-Century Blackface Minstrelsy, edited by Annemarie Bean, James V. Hatch, and Brooks McNamara, 3-32. London: Wesleyan University Press, 1996.

Maxwell, Hu. History of Monongalia County. n.p., [1900?].

McCurry, Stephanie. Masters of Small Worlds: Yeoman Households, Gender Relations, and the Political Culture of the South Carolina Low Country. New York: Oxford University Press, 1995.

. Confederate Reckoning: Power and Politics in the Civil War South. Cambridge: Harvard University Press, 2012. 
McDonnell, Michael. The Politics of War: Race, Class, and Conflict in Revolutionary Virginia. Chapel Hill: University of North Carolina Press, 2007.

McPherson, James M. and James K. Hogue. Ordeal by Fire: The Civil War and Reconstruction. $4^{\text {th }}$ ed. New York: McGraw-Hill, 2010.

Moore, George Ellis. A Banner in the Hills: West Virginia's Statehood. New York: AppeltonCentury-Crofts, 1963.

Noe, Kenneth W. Southwest Virginia's Railroad: Modernization and the Sectional Crisis. Urbana: University of Illinois Press, 1994.

Oakes, James. Freedom National: The Destruction of Slavery in the United States, 1861-1865. New York: W.W. Norton \& Co., 2013.

Parker, Granville. The Formation of the State of West Virginia: and other incidents of the late Civil War, with remarks on subjects of public interest, arising since the war closed. Wellsburg, WV: Glass \& Son, 1875.

Peterson, Merrill D. Democracy, Liberty, and Property: The State Constitutional Conventions of the 1820s. Indianapolis: Bobbs-Merrill Co., 1966.

Philyaw, Leslie Scott. Virginia's Western Visions: Political and Cultural Expansion on an Early American Frontier. Knoxville: University of Tennessee Press, 2004.

Pulliam, David L. The Constitutional Conventions of Virginia: From the Founding of the Commonwealth to the Present Time. Richmond: J.T. West, 1901.

Rice, Otis K. and Stephen Wayne Brown. West Virginia: A History. Lexington: University Press of Kentucky, 1993.

Richards, Leonard L. The Slave Power: The Free North and Southern Domination, 1780-1860. Baton Rouge: Louisiana State University Press, 2000.

Roediger, David R. Wages of Whiteness: Race and the Making of the American Working Class. New York and London: Verso, 1991.

Rorabaugh, W.J. The Alcoholic Republic: An American Tradition. New York: Oxford University Press, 1979.

Rosen, Hannah. Terror in the Heart of Freedom: Citizenship, Sexual Violence, and the Meaning of Race in the Postemancipation South. Chapel Hill: University of North Carolina Press, 2009.

Ryan, Mary. Civic Wars: Democracy and Public Life in the American City during the Nineteenth Century. Berkeley: University of California Press, 1997. 
Sappol, Michael. A Traffic of Dead Bodies: Anatomy and Embodied Social Identity in Nineteenth-Century America. Princeton: Princeton University Press, 2002.

Saxton, Alexander. "Blackface Minstrelsy." In Inside the Minstrel Mask: Readings in Nineteenth-Century Blackface Minstrelsy, edited by Annemarie Bean, James V. Hatch, and Brooks McNamara, 67-85. London: Wesleyan University Press, 1996.

Scott, Henry Dickerson. Iron \& Steel in Wheeling. Toledo, OH: Caslon Co., 1929.

Sellers, Charles. The Market Revolution: Jacksonian America, 1815-1846. New York: Oxford University Press, 1991.

Shade, William G. Democratizing the Old Dominion: Virginia and the Second Party System, 1824-1861. Charlottesville: University Press of Virginia, 1996.

Shanks, Henry T. The Secession Movement in Virginia, 1847-1861. Richmond: Garnett and Massie, 1934.

Simpson, Craig. A Good Southerner: The Life of Henry A. Wise of Virginia. Chapel Hill: University of North Carolina Press, 1985.

Sinha, Manisha. The Counterrevolution of Slavery: Politics and Ideology in Antebellum South Carolina. Chapel Hill: University of North Carolina Press, 2000.

Stealey III, John E. West Virginia's Civil War-Era Constitution: Loyal Revolution, Confederate Counter-Revolution, and the Convention of 1872. Kent, OH: Kent State University Press, 2013.

Tarter, Brent. The Grandees of Government: The Origins and Persistence of Undemocratic Politics in Virginia. Charlottesville: University of Virginia Press, 2013.

Thomas, William G. The Iron Way: Railroads, the Civil War, and the Making of Modern America. New Haven: Yale University Press, 2011.

Towers, Frank. The Urban South and the Coming of the Civil War. Charlottesville: University of Virginia Press, 2004.

Valencius, Conevery Bolton. The Health of the County: How Americans Understood Themselves and Their Land. New York: Basic Books, 2002.

Voss-Hubbard, Mark. Beyond Party: Cultures of Antipartisanship in Northern Politics before the Civil War. Baltimore: Johns Hopkins University Press, 2002.

White, Ashli. Encountering Revolution: Haiti and the Making of the Early Republic. Baltimore: Johns Hopkins University Press, 2010. 
Wilentz, Sean. The Rise of American Democracy: Jefferson to Lincoln. New York: W.W. Norton \& Company, 2005.

Wise, Barton H. The Life of Henry A. Wise of Virginia, 1806-1876. New York: The MacMillan Company, 1899.

Wyatt-Brown, Bertram. Honor and Violence in the Old South. New York: Oxford University Press, 1986.

Zaborney, John J. Slaves for Hire: Renting Enslaved Laborers in Antebellum Virginia. Baton Rouge: Louisiana State University Press, 2012.

Zakim, Michael. Ready-Made Democracy: A History of Men's Dress in the American Republic, 1760-1860. Chicago: University of Chicago Press, 2003.

Journal Articles

Ambler, Charles H. "The Cleavage between Eastern and Western Virginia." American Historical Review, 15, no. 4 (July 1910): 762-780.

— . "The Clarksburg Educational Convention of September 8-9, 1841." West Virginia History 5, no. 1 (October 1943): 5-54.

Barnes, L. Diane. "Urban Rivalry in the Upper Ohio Valley: Wheeling and Pittsburgh in the Nineteenth Century." Pennsylvania Magazine of History and Biography, 123, no. 3, (July 1999): 201-226.

Bernath, Michael T. "The Confederacy as a Moment of Possibility." Journal of Southern History, 79, no. 2 (May 2013): 299-338.

Conlin, Michael F. "The Dangerous Isms and Fanatical Ists: Antebellum Conservatives in the South and North Confront the Modernity Conspiracy." Journal of the Civil War Era, 4, no. 2 (June 2014): 205-233.

Crawford, B. Scott. "A Frontier of Fear: Terrorism and Social Tension along Virginia's Western Waters, 1742-1775." West Virginia History: A Journal of Regional Studies, 2, no. 2 (Fall 2008): 1-29.

Curtis, Christopher M. "Reconsidering Suffrage Reform in the 1829-1830 Virginia Constitutional Convention.” Journal of Southern History, 74, no. 1 (February 2008): 89124.

Engle, Stephen D. "Mountaineer Reconstruction: Blacks in the Political Reconstruction of West Virginia." Journal of Negro History, 78, no. 3 (Summer 1993): 137-165.

Fones-Wolf, Ken. "'Traitors in Wheeling': Secessionism in an Appalachian Unionist City." Journal of Appalachian Studies, 13, no. 1 and 2 (Spring and Fall, 2007): 75-95. 
Grigsby, Hugh Blair. "Sketches of Members of the Constitutional Convention of 1829-1830." Virginia Magazine of History and Biography, 61, no. 3 (July 1953): 319-322.

Grispan, Jon. "“Young Men for War': The Wide Awakes and Lincoln's 1860 Presidential Campaign.” Journal of American History, 96, no. 2 (September 2009): 357-378.

Ham, F. Gerald. "The Mind of a Copperhead: Letters of John J. Davis on the Secession Crisis and Statehood Politics in Western Virginia, 1860-1862." West Virginia History, 24, no. 1 (October 1962 to July 1963): 93-109.

Hunt, Thomas C. "Sectionalism, Slavery, and Schooling in Antebellum Virginia." West Virginia History, 46, no. 1-4 (1985-1986): 125-136.

Link, William A. "“This Bastard New Virginia': Slavery, West Virginia Exceptionalism, and the Secession Crisis." West Virginia History: A Journal of Regional Studies, 3, no. 1 (2009): 37-56.

Lowe, Richard G. "The Republican Party in Antebellum Virginia, 1856-1860." Virginia Magazine of History and Biography, 81, no. 3 (July 1973): 259-279.

Moore, George Ellis. "Slavery as a Factor in the Formation of West Virginia." West Virginia History, 18, no. 1 (October 1956): 5-89.

Pasley, Jeffrey L. "Party Politics, Citizenship, and Collective Action in Nineteenth-Century America: A Response to Stuart Blumin and Michael Schudson." The Communication Review, 4, no.1 (2000): 39-54.

Seaman, William M. "The Germans of Wheeling: Part One." Upper Ohio Valley Historical Review, 3, no. 2 (Spring-Summer 1979): 21-27.

Simpson, Craig. "Political Compromise and the Protection of Slavery: Henry A. Wise and the Virginia Constitutional Convention of 1850-51." Virginia Magazine of History and Biography, 83, no.4 (October 1975): 387-405.

Williams, John Alexander. "The New Dominion and the Old: Ante-bellum and Statehood Politics as the Background of West Virginia's 'Bourbon Democracy." West Virginia History, 33, no. 4 (July 1972): 317-407.

Wood, Nicholas. "John Randolph of Roanoke and the Politics of Slavery in the Early Republic." Virginia Magazine of History and Biography, 120, no. 2 (Spring 2012): 106-143.

\section{Dissertations AND MASTER's THESES}

Barnes, L. Diane. "Avenues to a Market Economy: Harrison County, West Virginia, to 1860." M.A. Thesis, West Virginia University, 1995. 
Baas, Jacob C. “John Jay Jackson, Jr.: His Early Life and Pubic Career, 1824-1870.” Ph.D. diss., West Virginia University, 1975.

Foulds, Matthew C. "Enemies of the State: Methodists, Secession, and the Civil War in Western Virginia, 1845-1872.” Ph.D. diss., Ohio State University, 2012.

Gaines, Jr., Francis Pendleton. "The Virginia Constitutional Convention of 1850-51: A Study in Sectionalism.” Ph.D. diss., University of Virginia, 1950.

Hizer, Trenton Eynon. "'Virginia is now divided': Politics in the Old Dominion, 1820-1833." Ph.D. diss., University of South Carolina, 1997.

MacKenzie, Scott Alexander. "The Fifth Border State: Slavery and the Formation of West Virginia, 1850-1868." Ph.D. diss., Auburn University, 2014.

Sutton, Robert Paul. "The Virginia Constitutional Convention of 1829-30: A Profile Analysis of Late Jeffersonian Virginia.” Ph.D. diss., University of Virginia, 1967.

\section{WEBSITES}

A State of Convenience: The Creation of West Virginia. Accessed 24 June 2015 to 26 July 2015, http://www.wvculture.org/history/statehood/statehood.html.

Ancestry.com. Accessed 25 August 2014 to 11 August 2015, http://search.ancestrylibrary.com.

Debates and Proceedings of the First Constitutional Convention of West Virginia. West Virginia Archives \& History: West Virginia Division of Culture and History. Accessed 14 July 2015 to 31 July 2015, http://www.wvculture.org/history/statehood/statehood11.html.

Dunaway, Wilma A. "Slavery and Emancipation in the Mountain South: Sources, Evidence and Methods." Virginia Tech, Online Archives. Accessed 13 January 2015, http://scholar.lib.vt.edu/faculty_archives/slavery/livestoc.htm.

"Inaugural Address of Governor Arthur I. Boreman." West Virginia Archives \& History: West Virginia Division of Culture and History. Accessed 21 June 2013, www.wvculture.org/history/boremania.html.

Ohio County Public Library. "The Belmont Nail Works, Wheeling, WV." Accessed 3 June 2015, http://www.ohiocountylibrary.org/wheeling-history/the-belmont-nail-workswheeling-wv/2707.

"A Proclamation on the Suspension of Habeas Corpus, 1862." The Gilder Lehrman Institute of American History. Accessed 29 July 2015, http://www.gilderlehrman.org/sites/default/files/content-images/06099p1_0.jpg. 
“Thomas Jefferson to Samuel Kercheval, 12 June 1816." TeachingAmericanHistory.org. Accessed 26 August 2014, http://teachingamericanhistory.org/library/index.asp?document=459.

University of Virginia. "Historical Census Browser, University of Virginia Geospatial and Statistical Data Center." Accessed 23 April 2013 to 19 March 2015, http://mapserver.lib.virginia.edu/index.html.

University of Virginia. “Zip Coon.” Uncle Tom's Cabin \& American Culture. Accessed 7 March 2013, http://utc.iath.virginia.edu/minstrel/zipcoonfr.html.

Virginia Department of Education. "Virginia Constitution, 1851." Virginia Government Matters. Accessed 14 April 2015, http://vagovernmentmatters.org/archive/files/vaconstitution1851_ded45111de.pdf. 